\title{
O fio da meada
}

Uma conversa e quatro entrevistas sobre Filosofia e Vida Nacional 


\section{O fio da meada}

Uma conversa e quatro entrevistas sobre Filosofia e Vida Nacional 
A coleção é organizada em sete categorias e três subcoleções, com diferentes tipologias documentais e formatos de arquivos:

Categorias: Filosofia; Política; Estética; Arquitetura e Cidades; Artes Plásticas; Crítica da Cultura e Trajetórias. Cada categoria adota uma cor específica aplicada na capa do e-book.

\section{Subcoleções:}

E-books: livros, capítulos, prefácios, artigos e entrevistas (em formatos PDF, EPUB e MOBI/Kindle) - com obras em português, inglês, espanhol, italiano e francês.

Documentos: matérias de jornal, fotos e documentos históricos (em formatos

PDF e JPEG)

Mídia: vídeos ou áudios de palestras, aulas e debates (em formatos MP3 e MP4) associados a um canal da coleção no YouTube.

Coordenação editorial: Pedro Fiori Arantes

Projeto Gráfico: Paula Astiz

DADOS INTERNACIONAIS DE CATALOGAÇÃO NA PUBLICAÇÃO (CIP) (CÂMARA BRASILEIRA DO LIVRO, SP, BRASIL)

Arantes, Paulo Eduardo, 1942--

O fio da meada [recurso eletrônico] : uma conversa e quatro

entrevistas sobre filosofia e vida nacional / Paulo Eduardo

Arantes. -- São Paulo: [s.n], 2021.

ePUB. - (Coleção sentimento da dialética / coordenação Pedro

Fiori Arantes)

ISBN 978-65-00-26508-8

1. Arantes, Paulo Eduardo, 1942- - Entrevistas. 2. Filosofia - Brasil.

3. Vida intelectual - Brasil. I. Arantes, Pedro Fiori, 1974-. II. Título.

III. Série,

CDD 199.81

Elaborado por Cristiane de Melo Shirayama - CRB 8/7610

DoI: https://doi.org/10.34024/9786500265088

\section{(c) $(1) \Theta \Theta$}

Esta obra tem licença Creative Commons internacional 4.0 http://creativecommons.org/licenses/by-nc-nd/4.0/

Publicado originalmente em livro:

ARANTES, Paulo. Fio da Meada: uma conversa e quatro entrevistas sobre filosofia e vida nacional. Rio de Janeiro, Paz e Terra, 1993.

\section{Sentimento da Dialética}

UM ENCONTRO COM A OBRA DE OTÍLIA E PAULO ARANTES

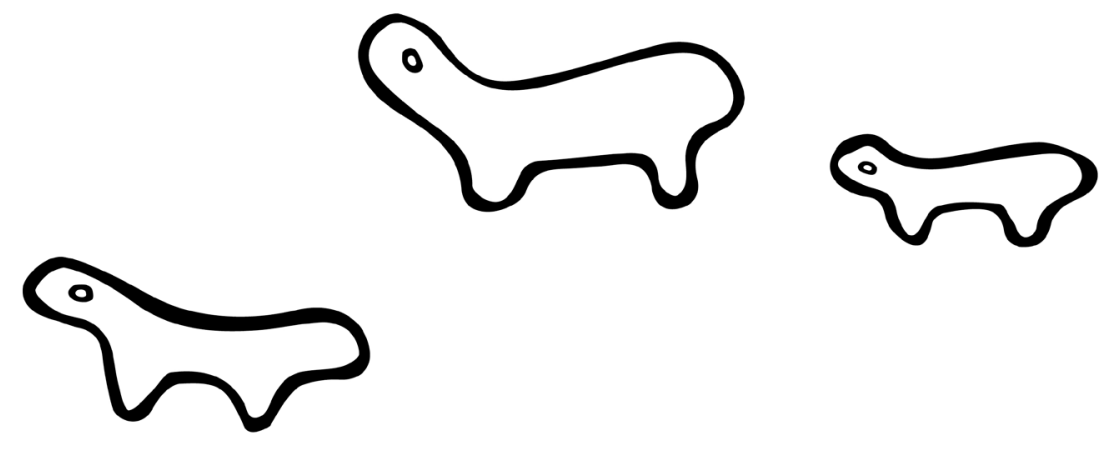




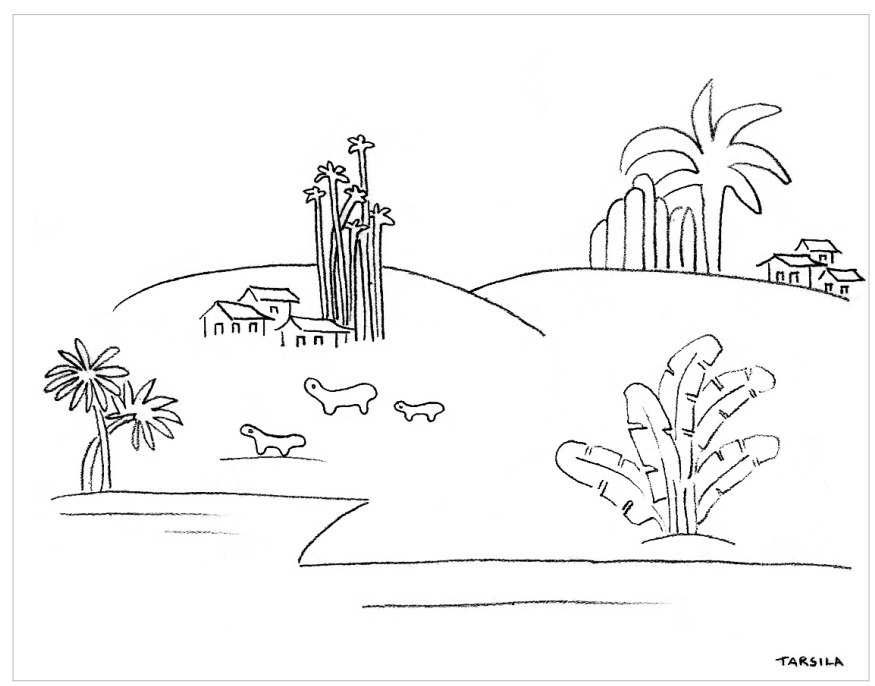

Tarsila do Amaral. Paisagem antropofágica - I, 1929 c - lápis s/ papel, 18,0 x 22,9 cm. Coleção Mário de Andrade. Coleção de Artes Visuais do Instituto de Estudos Brasileiros USP. Reprodução gentilmente cedida pela família e IEB USP.

O novo tempo do mundo exige dos intelectuais responsabilidades que lhes são intrínsecas: a de tornar a força das ideias parte do movimento de entendimento e transformação do mundo. Os filósofos Otília Beatriz Fiori Arantes e Paulo Eduardo Arantes cumprem, juntos, há mais de 50 anos, a tarefa da crítica como intelectuais públicos atuantes, transitando entre diversas áreas das humanidades e da cultura, em diferentes audiências e espaços de formação. A coleção Sentimento da Dialética é um lugar de encontro com a obra de Otília e Paulo Arantes e reafirma o sentido coletivo da sua produção intelectual, reunida e editada em livros digitais gratuitos. É um encontro da sua obra com um público cada vez mais amplo, plural e popular, formado por estudantes e novos intelectuais e ativistas brasileiros. É também um encontro da sua obra com o movimento contemporâneo em defesa do conhecimento livre e desmercantilizado, na produção do comum e de um outro mundo possível. 
O Fio da Meada

319 Uma História dos Paulistas no seu Desejo de ter uma Filosofia

349 Crise de Paradigmas em Itaguahy

365 Ajuste intelectual 
Ao Pedro,

porque no le gústan los espejos de su padre 


\section{O Fio da Meada*}

"Ele pensava dentro de outras cabeças; e na sua, outros, além dele, pensavam. Este é o verdadeiro pensamento."
Bertold Brecht*
Christine Röhrig (CR) - Você se importaria de se apresentar?

Paulo Arantes (PA) - Não. Ainda não dispenso apresentação, nem há muito o que apresentar.

CR - Pode ser. Mas a ficha técnica da orelha não daria conta de encaixar, por exemplo, a delicada informação de que estamos publicando material que ficou para trás.

PA - E que o autor ainda não tem idade para se dar ao luxo de reunir papéis velhos...

Maria Elisa Cevasco (MEC) - Idade até que tem. Se não me engano, foi no Prefácio de uma edição de Raízes do Brasil, acho que a $5^{\mathrm{a}}$ ou a $6^{\mathrm{a}}$, o Antonio Candido disse com todas as letras que aos maiores de cinquenta já é possível fazer balanço do passado sem cair em autocomplacência.

\footnotetext{
* Uma conversa com Christine Röhrig, Maria Elisa Cevasco e Iná Camargo Costa. - Até onde me lembro, esta conversa nasceu de uma sugestão de Maria Elisa Cevasco. Originalmente a ideia era a de uma entrevista com o Autor a respeito do livro Ressentimento da Dialética a ser lançado pela editora Paz e Terra, a título de Posfácio. Em pouco tempo a entrevista desandou numa conversa que por sua vez perdia o foco com facilidade. Decidiu-se continuar assim mesmo, a ver no que dava. O resultado aí está, graças à fantasia exata de Iná Camargo Costa na edição final do material penosamente recolhido
} 
PA - Obrigado pela autorização. Mas você sabe muito bem que ele não estava se referindo a cinquentões quaisquer e sim a uma geração que aprendeu a pensar refletindo sobre o Brasil na esteira da grande rotação de eixo cultural induzida pela Revolução de 30. Os meus cinquenta e três anos incompletos evidentemente não me habilitam a coisa nenhuma, a não ser falar dos outros fingindo falar de mim. Ou melhor, mesmo neste capítulo das gerações incomparáveis parece que teremos voz, maiores ou menores de cinquenta, tanto faz: é que o objeto cujo estudo ensinou nossos pais fundadores a pensar está se desmanchando sob nossos olhos. Como ficamos? O que nos fará pensar, além é claro do primeiro degrau representado pelo atual processo de desintegração nacional? Alguém já observou muito bem que toda vez que a referência nacional entra em baixa, a vida intelectual resvala para a irrelevância. Aliás, quem cuida profissionalmente de filosofia no Brasil sabe muito bem disso.

CR - Eu também estou interessada em saber como ficamos, mas primeiro me interessa saber onde estamos. Quanto a mim, estava no seguinte ponto: dos seus estudos antigos reunidos no presente volume - aliás, o objeto desta conversa, é bom não esquecer -, o mais antigo tem vinte anos e o mais novo está completando doze, sendo que por alguma razão uma parte deles ainda estava na gaveta. Agora sim, como ficamos? Por isso pensei, para começar, numa ficha técnica um pouco mais detalhada. Espero que entendam, não é uma questão de idade avançada ou envelhecimento precoce. Ainda outro dia, o Dr. Fernando, folheando os originais, me disse o seguinte: se eu fosse você, mudaria de epitáfio, de "aqui jaz quem tentou editar Brecht", para "aqui jaz Christine Röhrig, porque editou esse tal de Paulo Arantes”...
PA - Não se preocupe com isso. O Dr. Fernando sempre lançou generosamente os prejuízos da atividade editorial no Brasil na rubrica "em defesa do interesse nacional".

Iná Camargo Costa (ICC) - Se é para continuar nessa desconversa, deixem a ficha técnica comigo que eu tiro de letra. Veja o professor se o resumo confere. Você começou em 1968 dando aula de Lógica e História da Filosofia Contemporânea. Durante algum tempo chegou a preparar uma tese sobre Filosofia da Matemática em Hegel, que acabou virando um doutorado sobre o problema do Tempo no mesmo Hegel, defendido em Paris em 1973 e traduzido para o vernáculo em 1981 por Rubens Rodrigues Torres Filho.

PA - O original era um pastiche do Le Monde, a cujas fórmulas eu sempre recorria nas horas de aperto. A tradução do Rubens quase chegou a me convencer de que eu sabia escrever em português, sem falar nas notas muito oportunas em que explicava ao leitor brasileiro que Hegel não entendera bem o que vinha a ser a Doutrina-da-Ciência de Fichte.

ICC - Muito bem, continuando. De volta a São Paulo, você publicou quatro pequenos estudos (um por ano, aliás, naqueles bons tempos vagarosos e improdutivos da Faculdade) sobre a Ideologia Alemã. Não o livro, mas as vítimas de Marx, na pessoa sobretudo de um pobre diabo chamado Max Stirner. Eles figuram no Apêndice do presente volume.

PA - Com o primeiro desses estudos estreei em 75 numa reunião da SBPC. Era marinheiro de primeira viagem. 
Diante de uma pequena multidão interessada em ouvir Marilena Chauí, Claude Lefort, Gérard Lebrun e Bento Prado Jr., li sem microfone um pequeno trecho da mais arrevesada prosa sobre o infeliz Stirner. Acho que fui ouvido até a terceira fila. Da quarta em diante, uma alma caridosa e progressista informou aos demais que eu estava metendo o pau no Skinner. Não se pode dizer que eu não contribuí para o esforço de resistência à Ditadura. No ano seguinte reincidi com segundo estudo. Desta vez sobre a Esquerda Hegeliana e o sucesso de público de Schopenhauer depois do malogro da Revolução de 48 - um tema da maior atualidade, como vocês podem ver: dinamite pura contra a fronda conservadora do governo Geisel. O Giannotti, que também falou (a propósito de um camarada que arremessa uma bola contra uma parede, e depois para um segundo jogador, que hoje resultou num jogo de linguagem não verbal, mas na época funcionava como esquema ontológico da ancoragem da história no ardil do trabalho), fez saber ao meu tutor, Bento Prado, igualmente presente e que me havia convidado, que o protegé dele estava arruinando a carreira com aquele lixo historicista. Os dois estudos seguintes saíram direto do meu escritório para a revista Almanaque, aliás encomendados pelo mesmo Bento Prado, que apreciava a coisa embora os considerasse, com razão, prolixos e por vezes francamente herméticos.

ICC - Bom: se a cada item corresponder uma ementa sentimental, estamos arranjados. Se não houver objeções, posso continuar. A partir de 1979, o professor aqui iniciou uma série, metade na gaveta, a outra publicada em revistas, sobre as origens intelectuais da dialética hegeliana, com muitas digressões sobre a vida intelectual no século
XVIII francês e começos do oitocentos alemão, com um breve suplemento sobre a impregnação de Heidegger pela “miséria alemã”. Esse é o material que compõe o livro na berlinda neste momento. Como conheço bem o espírito e a letra dele (por ter colaborado na datilografia e revisão), dei pela falta de dois capítulos (por assim dizer): um sobre a contribuição do salão de Rahel Varnhagen para o conceito alemão de Cultura, e outro sobre fragmento e ensaio no primeiro romantismo de Iena. Não, não precisa explicar. Ou melhor, dá para entender, porque a Christine acha que o leitor merece uma explicação. É que, sem aviso prévio, você interrompeu esta segunda série em 83 para se dedicar a nada menos que a obra de João Cruz Costa, o que também não levou adiante, depois de dois artigos e outros mais engavetados. O Bento, que tinha acompanhado esse interesse extemporâneo por Cruz Costa, passou-lhe, anos depois, a encomenda de um artigo sobre o Positivismo no Brasil para uma revista francesa. Esse artigo lhe valeu um amistoso passe de armas com um especialista brasileiro na matéria.

MEC - Espero que esses ziguezagues tenham algum método. Mesmo assim, você há de convir que o seu dossiê desconcerta. E ainda não terminamos. São muitos altos e baixos - no bom sentido, claro. Por exemplo: o que levaria o autor de uma tese cabeluda sobre Hegel a se interessar pela filosofia menor de um João Cruz Costa, para usar os termos, se não me engano, do título de um artigo seu sobre o assunto, acho que publicado numa remota revista de um grotão do Rio Grande do Sul.

PA - Grotão, vírgula, capital da soja. Filósofo menor, quem sabe, porquetinha o tamanho fluminense do Brasil. Ecomo 
sabia muito bem disso, não devia ser tão pequeno assim. Sendo, aliás, gordo e baixinho, não podia aspirar à condição de filósofo maior, não tinha nem mesmo o physique du rôle. Quanto a nós, seus netos uspianos, que não sabíamos nada disso nem queríamos saber, sequer desconfiávamos do estado de paródia involuntária em que vivíamos - como já lembrou um observador das coisas brasileiras, mas não a nosso propósito, é claro. Ora, Cruz Costa, que tinha um olho clínico para esses arremedos, desenvolvera um gênero de piadismo filosófico, mais para a chalaça portuguesa do que para ironia encoberta que, sem ser um argumento, era uma advertência cuja força profilática derivava do fato de se apresentar espontaneamente estruturado à imagem e semelhança das dissonâncias nacionais. De modo que nunca sabíamos ao certo: Husserl no bairro da Aclimação, seria como um pavão no quintal da comadre Angélica em Barbacena, ou como uma ninfa no Ribeirão do Carmo? Pelo sim, pelo não, embora tenha passado a vida se divertindo às custas da filosofia - sendo o Brasil, no caso, uma prova dos nove mortal -, Cruz Costa em nenhum momento deixou de satisfazer, em termos de providências cabíveis, o desejo dos professores mais jovens de dotar o Brasil de mais um melhoramento da vida moderna, a saber, a cultura filosófica funcionando de verdade num país periférico. Dito isto, gostaria de acrescentar que, mesmo tendo escrito muito sobre filosofia, não há uma gota de filosofia no que publiquei até agora. Por isso não vejo nenhuma queda vertiginosa das altas paragens da especulação filosófica na realidade mesquinha que é a vida das ideias entre nós. Se não for presumir demais, acho até que houve uma ligeira ascensão.

MEC - Mas se nem na tese sobre Hegel havia filosofia, então o que havia ali?
PA - Dissertação, muita dissertação. Aliás, nem mesmo isso. Certa vez, lá pelas tantas, meio desanimado com o meu futuro de aluno aplicado, confessei imprudentemente ao meu professor Bento Prado que não gostaria de passar a vida fazendo dissertação. Ele fulminou: mas quem disse que você sabe? Mais uma razão para pular fora na primeira oportunidade, e como custou a chegar - se é que não continuo ofuscado.

ICC - Aviso aos navegantes: última tentativa de encerrar o capítulo vida e obra. Vamos lá: no mesmo ano em que largou seus estudos alemães, o autor aqui presente estreou por fim em jornal com uma falsa resenha do primeiro livro de seu ex-professor Ruy Fausto, mero pretexto para comentar aspectos do capítulo brasileiro, filosófico, bem entendido, do assim chamado (por Perry Anderson) marxismo ocidental. Do Positivismo no Brasil, passou a um conjunto de estudos sobre a formação da cultura filosófica uspiana, reunidos em livro depois de pingarem durante oito anos. Entre um pingo e outro, as seguintes entradas: aproveitando a deixa da Missão Francesa, que tornou possível a realização do desejo dos paulistas de ter uma filosofia, estudos sobre a filosofia francesa de vanguarda, realizados com ânimo comparativo, se não me engano, e com vistas à sua irradiação mundial, Estados Unidos inclusive (até agora dois artigos sobre Rorty, para variar prometendo continuação); em parceria com Otília Arantes, uma plaquete sobre os tropeços de Habermas diante da Arquitetura Moderna e a dimensão estética depois das vanguardas; logo a seguir uma outra, sobre o método crítico de Antonio Candido e Roberto Schwarz, aliás precedida por um longo artigo sobre a ideia de Formação no primeiro, que saiu no livro Dentro do texto, dentro da 
vida, organizado pelo pessoal da UNESP. Confere? Paulo: depois de responder, lembre-se de que você ficou devendo à Christine uma explicação para a exumação daqueles textos antigos. Dizer que é só pelo pitoresco do documento de época, para governo da moçada, não vale.

PA - Não só confere, como fico agradecido. Se essa ficha técnica tivesse ficado por minha conta, teria sido muito difícil não cair no ridículo, mesmo com a atenuante da meia-idade, de ficar fazendo a torto e a direito balanços da própria "obra" - e ponha-se aspas nisso. Aliás nem sei se já não caí de vez. Seja dito em minha defesa, que esse vezo provinciano é histórico, por assim dizer integra a carga genética de todo intelectual brasileiro e quando não aparece é porque deve ser recessivo. Assim sendo, não estou em má companhia. Sílvio Romero, por exemplo, deu-lhe feição monumental: aos vinte anos já tinha inaugurado o gênero balanço precoce. Devia com certeza ter pressa, pois não era nada fácil a vida intelectual no tempo dele. Em todos os sentidos o fôlego era curto, por isso pouco produzimos, cedo nos cansamos, envelhecemos e morremos depressa - como diria. Porém, tudo bem pesado, isto é, salvo pelo flagrante despropósito, não deixava de ter uma certa dose de razão, involuntária, é claro. Resumindo a três por dois sua evolução, a suposta lógica inexorável que comandaria as marchas e contramarchas de suas ideias, imaginava estar contribuindo com essa ficção patriótica para sanar uma grave falha nacional, a falta de seriação em nossas ideias, para falar na língua dele, domínio em que nada se seguia de coisa nenhuma, ao contrário do esprit de suite europeu, devido ao vínculo muito frouxo, nulo ou simplesmente diferente, entre vida mental e pasmaceira colonial, o que não o impedia de ir substituin- do uma por outra quanta doutrina de cara nova lhe aparecesse pela frente. Como o problema não desapareceu, é bom ficar de olho.

MEC - Pode ficar sossegado, nenhum dos presentes vai cometer a tolice de correr atrás do "fio condutor" de obra filosófica nenhuma.

PA - Mas deveriam. Acho até que essa questão aparentemente desfrutável de "obra" vale uma digressão. Vista do ângulo certo, ela é substantiva. Torna-se ao contrário bisonha quando encaramos a pouco animadora sequência dos nossos papers acerca dos tópicos obrigatórios na bibliografia do momento como o indício seguro de uma "evolução" filosófica. Não se trata de um problema de talento ou, pior ainda, originalidade, o qual, a partir de um certo limiar de socialização intelectual passa a ser quase desimportante, mas de um problema de formação, na acepção brasileira do termo. Vejamos então tudo isso mais de perto, observando uma carreira exemplar entre todas, justamente encarada pelo nosso pequeno mundo filosófico como a mais forte promessa de “obra”. Não é por implicância, é até por sincera admiração que lhes proponho reexaminar um aspecto do caso Giannotti, aliás dimensão também na berlinda numa entrevista recente (abril de 95) a propósito do lançamento do livro dele sobre Wittgenstein.

Dona Iná, vou precisar recapitular um pouco, para governo dos mais jovens. O enorme passo dado por nosso filósofo público número um, da Epistemologia francesa e da Fenomenologia husserliana ao Capital, empurrado é claro pelo grupo do Seminário Marx, do qual ele era por sua vez a mola propulsora metodológica, resultou num pri- 
meiro livro muito original sobre a Dialética do Trabalho em Marx, seguido logo depois por um notável enquadramento do positivismo althusseriano então hegemônico naquela segunda metade dos anos 60 e mais adiante por um livro cavadíssimo ao longo de uma década. O conjunto concorria então para reforçar a impressão de que era iminente a abertura de uma janela para o mundo contemporâneo, como davam a entender as páginas finais do livro sobre a implosão da sociedade do trabalho. Mas o que se viu afinal foi outra coisa. Em lugar do esperado resultado e novo arranque em continuidade, o desengano do próprio autor que, ato contínuo, passou a desancar a ideia tola e passadista de "obra", iniciando então pregação correlata em favor da fragmentação e seus derivados, pregação em prol do capricho libertário que emanaria da única coisa que doravante conta: a "obsessão". Onde antes havia pertinácia e muita obstinação, algo como uma teimosia produtiva na perseguição de um problema desentranhado do campo social de forças intelectuais em presença, encontramos agora o elogio do estilo idiossincrático em estado bruto, e com direito a gramática própria. É bem verdade que Giannotti teve o grande mérito de se deixar atropelar por uma manobra radical do capitalismo em pessoa, sinal inequívoco de que o nosso filósofo corria por uma pista realmente existente, o que nem de longe é a regra no caso da filosofia profissional propriamente dita, por isso mesmo perene na sua rigidez cadavérica. Só que em vez de conceptualizar o fetiche que o derrubou, Giannotti estilizou o desmentido na forma de sucedâneos fraseológicos daquele mesmo fetiche, "intimidade", "ética", "jogo de linguagem", "gramática da existência", e tudo o mais que veio à tona com a grande guinada conservadora do mundo. Isso por um lado, por assim dizer o lado mais carrega- do de experiência real, no entanto simplesmente sofrida sem maiores mediações, mas não por falta de meios à altura, se levarmos em consideração o fato nada negligenciável de que Giannotti era o mais preparado de todos.

MEC - Se eu captei bem o espírito da coisa, já posso ir adiantando o inevitável "por outro lado”. Dá para sentir no ar as semelhanças de família. Não é assim que se fala na língua do tal de segundo, ou terceiro Wittgenstein, sei lá? Os críticos literários americanos andam apelando muito para esse bordão, por sinal muito pragmático... Quer dizer que estamos de volta ao pequeno mundo antigo de Sílvio Romero? Fico, no entanto, pensando no que o Antonio Candido dizia dele, que essa agitação turbilhonar do Sílvio Romero era a imagem nervosa do país.

PA - Mas o Giannotti também, não tenha dúvida. Mal comparando também, vale para ele o que o Cruz Costa gostava de dizer do Tobias Barreto, o tal que afiançava que o Brasil não tinha cabeça filosófica, porque não entendia a algaravia germanófila dele, é claro: ele era o Brasil (filosófico), errado, mas vivo.

MEC - Contudo, um pouquinho mais de fibra não faria mal.

PA - Mas eu não estou advogando a continuidade pela continuidade, não sou baluartista.

MEC - Muito menos eu. Estou apenas reparando com os meus botões que no ensaio literário não se entrega a rapadura assim tão facilmente não. E não venha me dizer pela enésima vez, Antonio Candido dixit: desde os primórdios 
da nacionalidade, a vida do espírito em nosso país girou essencialmente em torno da literatura, quem entrava em literatura (com perdão do galicismo) era para contribuir na construção da dita nacionalidade. Isto na fase de incorporação literária. Veio depois o momento de depuração, de valorização estética da forma, a maioridade pelo equilíbrio entre o aprofundamento do dado local e a força generalizadora da construção, etc. Você já andou tratando disso nos seus ensaios sobre o Antonio Candido, se não me engano.

PA - Veja, no entanto, que você deixou de lado o ensino de crítica literária, e se pensarmos nas sucessivas boatarias terminológicas, do New Criticism às atuais Teorias do Discurso, a vaca literária também foi pro brejo junto com a vaca filosófica. Mas podemos conversar a respeito, pois a Crítica é bom termo de comparação para sentir o drama dos filósofos.

ICC - Eu tenho muito interesse nisso, mas em outra hora. Agora o Paulo vai fazer o favor de encerrar a digressão.

PA - Assim de encomenda fico encabulado, como a Emília, a Marquesa de Rabicó.

CR - Não seja por isso. Lembre-se que ainda estou esperando a explicação necessária, devida ao leitor, já que não se publica impunemente um livro treze anos depois de abandonado. Quando digo impunemente estou pensando em mim, é claro. Espero que o tal fio condutor passe pelo livro que estou oferecendo ao público, confiando num autor da casa.
ICC - Se não passar, nós enforca ele com o próprio. E como já deu para perceber que o autor da casa com facilidade perde o foco, proponho a adoção dos seguintes critérios ad hoc: apartes polêmicos serão bem-vindos, deixas para novos parênteses serão peneiradas, e digressões de moto próprio em princípio barradas, embora eu mesma não prefira o estilo cowboy direto-ao-ponto.

PA - Só falta pigarrear. Pois voltemos a implicar um pouco mais com o Giannotti, concordando de saída com Sílvio Romero redivivo, lembrado pela Maria Elisa. Temos, portanto, os dois lados e o lado oposto: num canto, o Brasil velho de cujos avatares não conseguimos nos livrar por melhor que planejemos nossas instituições, no caso a instauração filosófica no país; no outro, um dado inequívoco de atualidade: a famigerada "obra" partida ao meio é um caso patético de construção interrompida, para falar como Celso Furtado. A súbita desarticulação dela tem tudo a ver com a formação nacional encalacrada, senão abortada de vez. Veja, Dona Iná, que reencontrei o foco, meio aos trambolhões, reconheço, se estão lembradas Vossas Excelências de que começamos pelo cidadão de cinquenta anos que por mexer profissionalmente com filosofia não aprendeu a pensar refletindo sobre o Brasil e por isso mesmo desconfio que não aprendeu a pensar. Terá que reaprender agora que a referência daquele impulso reflexivo está mudando para pior. Pois feita a ressalva, retomemos as "obsessões” do Giannotti e os seus dois lados, República Velha, Capitalismo-cassino. Obsessão? Seja: mas se trata então da mesma coisa que vem sendo refeita há trinta anos, como disse em polêmica José Veríssimo, confrontado com o espetáculo desencontrado oferecido pela dita movimentação turbilhonar de Sílvio Romero. 
MEC - Mas e se o Giannotti, agradecido pela comparação, replicasse: bem-aventurados os que se podem repetir, os que dizem sempre a mesma coisa?

PA - Estaria admitindo que mandou às favas Marx e Cia. com a mesmíssima e desfrutável desenvoltura com que Ślvio Romero ia devorando e abatendo quanta doutrina nova lhe surgisse pela frente, substituindo um arremedo pelo outro, como lembrou outro crítico. Na condição de cidadão de uma cultura reflexa, imaginava que só poderíamos nos desenganar de uma ilusão sob a tutela de uma outra, mais recente e mais poderosa.

MEC - E o seu filósofo - até segunda ordem, o mais enfibrado de todos-, como se explicaria?

PA - Mais ou menos nos seguintes termos: a mesma "obsessão" - um ideólogo alemão, ou um russo oitocentista, preferiria falar em "ideia fixa" - pode indiferentemente se exprimir ora na linguagem da fenomenologia husserliana, mais adiante nas fórmulas de Marx, agora na língua do segundo Wittgenstein, amanhã sabe-se lá na de qual outro luminar do momento, sendo tudo uma questão de miolo inalterável e revestimento sazonal. Acho que nem Fichte, muito flexível na questão das infinitas possíveis exposições da Doutrina-da-Ciência, já que a última palavra cabia à imaginação democraticamente genial de cada um, deixaria passar em branco um vínculo tão volúvel assim entre "letra" e "espírito". Sem falar que o catecismo franco-uspiano sempre interditou expressamente qualquer separação entre Doutrina e Método, prevenindo-se sabiamente contra a eventualidade, digamos, de uma tese cartesiana na linguagem de Hume e por aí afo- ra. É bem verdade que este mesmo breviário estimulava por outro lado uma técnica dissertativa cujo segredo residia na habilidade em juntar textos que aparentemente jamais podiam andar juntos, como se o estilo mogiana bem paulista, submetendo caprichosamente o traçado da ferrovia à localização de fortuna das fazendas senhoriais, se reproduzisse na retórica filosófica dos filhos da terra, ela também uma máquina de moer o relevo específico de tudo que venha ao caso. Como as digressões de moto próprio estão proibidas, não me atreveria a sugerir algo do seguinte teor, na verdade um curioso entrecruzamento: como o nosso vezo profissional dissertativo-historiográfico tem certamente a idade histórica da invenção da filosofia transcendental (Kant, Fichte, o primeiro Schelling), e com isso quero dizer que nossa salutar indiferença doutrinária (a marca de fábrica da maneira uspiana de lidar com os sistemas filosóficos do passado) tem tudo a ver com o retorno reflexivo da razão sobre os seus procedimentos específicos, movimento de exílio cósmico no centro do qual Fichte fincou a bandeira da imaginação soberana, seria o caso de reparar que o declínio moderno desta faculdade, que definha junto com a atrofia do sujeito que ela engendrou, corre paralelo à crescente formalização do momento retórico-expressivo de que estávamos falando. Nasceram em constelação, porém enquanto a imaginação definha fantasiando que o seu poder goza de latitude máxima por não estar represado nos limites de nenhuma egoidade substantiva, o seu correlato no plano da "letra" engorda até os confins do excesso absoluto por falta de lastro referencial. O curioso do fenômeno é que, visto de um certo ângulo, não se poderia dizer que ele consumiu um século para cristalizar, o tempo da ordem capitalista competitiva encruar, mas já se dava a conhecer por inteiro nas 
reviravoltas da vanguarda romântica de Iena, prova suplementar de que a modernização burguesa carrega consigo desde a origem tudo de que necessita para extrair no ato alienação de emancipação.

ICC-É bom parar por aí.

PA - Já tinha parado.

ICC - Então aqui vai uma colher de chá. Essa coisa muito embrulhada - pela brevidade, é claro - que você acabou de sugerir poderia ser prolongada até o caso Giannotti, por enquanto em pauta, notando em consequência que a "obra" (dele) desfeita se resolve num formalismo de mesmíssima raiz que o recém evocado na sua origem alemã e no seu correspondente desfecho franco-uspiano, formalismo evidente e consolidado na indiferença aos conteúdos filosóficos literais concernidos. Mais uma, pensando nos seus esquemas do Departamento francês de ultramar: essa ausência de obra na qual se sublima o formalismo em questão é uma prova sem dúvida eloquente, tratando-se de quem se trata, de que não há linha evolutiva entre nós que resista ao menor solavanco, de que a esta sina de sociedade mal-acabada é particularmente vulnerável nossa recente "formação" filosófica - data vênia para o "nossa”, pois quem fala também é bacharel em filosofia pela mesma escola.

PA - A qual "formação" no entanto realmente se completou, apesar de todos os pesares, embora de fato de um momento para outro possa se desmanchar. Mas, ao dar em nada, isso não quer dizer que a filosofia como tal deixe de funcionar em nosso meio. Pelo contrário, é nessas horas que prospera a todo vapor, a mídia que o diga.
CR - Se é assim, também vou dar uma de primeira da classe. Não só li o livro que editei como acho que entendi. Aliás, nem é tão complicado sacar o chiqueirinho dos filósofos. Quer dizer então que essa momentosa questão da "obra" de que vocês tanto falam (desconfio que para não entrar no assunto que me interessa) só deixa de ser inepta quando pensada contra o pano de fundo desses acidentes monumentais? Forte coisa... Que o Prof. Fulano tenha trocado o filósofo francês X pelo americano Y ou o alemão $\mathrm{Z}$, sempre me pareceu óbvio que não tem a menor importância. Desculpe a falta de jeito, mas é que, depois de tanto ler Brecht, torna-se difícil ficar ao mesmo tempo nos assuntos gerais e manter a cabeça no lugar.

PA - É isso aí. Para muito colarinho branco só mesmo dizendo Não. Mas Iná, você falou em ausência de obra. Não creio que tenha sido de caso pensado, pois a expressão era predileta de Maurice Blanchot, que com certeza não é santo da sua particular devoção. Sem dúvida, foi por contaminação objetiva, pois já estamos navegando nas águas da antiga metafísica literária característica da Ideologia Francesa faz algum tempo. É preciso no entanto corrigir. A expressão, cunhada por Blanchot e posta em circulação nos primeiros tempos da filosofia literária parisiense da Transgressão, remonta à velha tensão modernista, mas já então inteiramente rotinizada, quer dizer, girando em falso, mimetizando no vácuo da mera fórmula protocolar a polêmica de Mallarmé com a obra-coisa da cultura burguesa nos seus primórdios. O fuso histórico, no entanto, variou, atrasamos o relógio ao avançar: a "obra" está de volta, mas na forma rarefeita do seu suporte, o próprio sujeito e suas "obsessões", obsessões que os mais atualizados chamariam de "redescrições", de sorte que Husserl, Marx 
ou Wittgenstein são apenas "vocabulários" a escolher na intenção da fronteira contingente que no momento interessa transpor. Somos esta “obra” em estado de animação estilística permanente: essa a derradeira metamorfose do fetiche contra a qual investia a estética antiburguesa de Mallarmé.

Em resumo, o Brasil antigo de Sílvio Romero, país carecido de forma, como ele mesmo se referia ao fundo falso que nos roubava o fôlego e a seriação nas ideias, correu ao encontro de um último efeito da forma-mercadoria, que de novo se encarregou de nivelar, e como sempre por abstração, os desiguais. De sorte que onde se lia "obra", leia-se, repito, redescrições indiferentemente intercambiáveis de coisa nenhuma (no bom sentido, pois se trata de construções sem essência), o que pode inclusive atender pelo velho nome de obsessão, por certo à procura de uma "regra" a ser seguida. Afinal, somos modernos, e por isso refletimos, e quem reflete procura uma regra que o oriente, no pensamento inclusive: daí partimos (como lembrei de passagem e referindo a Fichte para facilitar), da reflexão sem amarras do sujeito autoconsciente para finalmente encalhar, como se fosse uma liberação, numa estilística fetichista da existência, pois a regra a ser seguida não deve sobreviver ao curto espaço lúdico de uma temporada.

Me ocorrem agora dois contraexemplos para que se possa sentir melhor o drama, senti-lo por comparação, o drama da cultura filosófica entre nós, uma das últimas a alcançar a rede orgânica de referências cruzadas que anunciam as "formações" em vias de se completar. Por exemplo, não dá para imaginar um Celso Furtado estilizando o fim de linha em que nos debatemos, mais ou menos nos seguintes termos: na verdade não deixei uma "obra" que tenha sido desmentida pelos fatos - admitindo-se, para encurtar, que não haja mais argumentos contra os ditos fatos - mas uma série de livros e providências práticas em que manifestei sempre a mesma "obsessão", variando apenas a armação vocabular contingente com que a cada vez redescrevia minha paixão pelo enigma Brasil. Assim, uma palavra de ordem como "superação do subdesenvolvimento" foi apenas uma maneira de falar entre muitas outras, e hoje que não somos mais um país subdesenvolvido, mas apenas injusto, porém com moeda conversível e geração endógena de tecnologia, meu jogo de linguagem seria outro, caso estivesse na ativa. Não seria menos grotesca ou simplesmente amalucada uma outra fabulação como a seguinte: diante da referência nacional rifada, imaginar um Antonio Candido encaixando com júbilo o golpe que teria vindo em boa hora sacudir a poeira do atraso, como nos pedem com zelo desconstrucionista nas altas esferas do poder central, ensaiando um novo movimento como Montaigne em sua livraria: de fato, minha "obsessão" com a formação da literatura brasileira - que aliás nem minha era, mas das "capacidades" de antigamente, que desejavam dotar o país novo de uma benfeitoria tal que algum dia poderia até ser exportada obteve um certo desafogo no jogo de linguagem logocêntrico da Origem. Hoje eu me redescreveria melhor quem sabe... e o raciocínio por certo não se completaria por se encontrar o autor sabidamente desatualizado faz tempo. Mas cessando a blague é claro que o problema fica.

MEC - Que problema, que eu já não lembro mais?

PA - Não seja esse o problema, eu recapitulo. 
ICC - Mas nem que a vaca tussa!

PA - De outro modo, é claro.

ICC - Nem pensar. Vejamos: você desconversou, ciscou o que pôde, mas ainda não desfez a má impressão inicial, a alternância de assuntos nobres e corriqueiros, autores maiores e menores, sem falar numa visível inapetência para questões teóricas. Dá pra notar até na conversa. Aliás, ultimamente você anda escrevendo como fala, e vice-versa, o que no seu caso ainda não sei se é bom ou mau - é que de um relógio pra outro as hora vareia...

PA - Vocês estão mesmo querendo me comprometer de vez, me expondo nas tais súmulas brasileiras caipiras. Tudo bem, esse risco é mesmo parte do problema e, por se encontrar no miolo do meu assunto, me arrasta para a tarefa sempre delicada de registrar em primeira pessoa uma experiência coletiva, foco aliás inevitável no gênero misto entrevista-conversa fiada. O dilema seria então o seguinte: ou tiro da cartola uma impossível evolução à europeia, ou então entrego os pontos confessando que, como todo mundo, venho ziguezagueando como uma ventoinha.

ICC - Pois nós achamos que o dilema é falso e não estaríamos aqui se não pensássemos assim, só por amizade. Achamos, além disso, que há uma terceira via, o que não garante que você também não esteja correndo por uma pista de fantasia.

PA - Agradecido. Voltemos então ao primeiro capítulo dessa novela toda, que poderia se intitular: drama de consciência da filosofia profissional. Ele é provinciano, mas não deixa de ter alcance histórico-mundial, para falar à maneira inflada da antiga esquerda hegeliana. Não por mérito do nosso cantinho. É que, sem pedir licença, o tal processo inclusivo passa pela mesa de trabalho do professor de periferia preparando seus cursos e derivados, podendo sem aviso prévio deixá-lo falando sozinho, aliás como também seu confrade metropolitano, pois o tal processo é muito equânime neste ponto. Um professor de História da Filosofia, se for dos bons e tiver passado por uma das boas escolas historiográficas, como a francesa, poderá sem dúvida deixar atrás de si um número razoável de livros de qualidade, em alguns casos até completar o álbum de figurinhas escrevendo de $\mathrm{A}$ a $Z$, coleção que por sua vez alimentará um outro ciclo de futuras dissertações, e assim por diante. Já contei que o professor Bento Prado teve a bondade de me prevenir: nesse gênero você vai se dar mal. (Aliás ele poderia descontar, retificando a profecia: corrijo-me, pois você continua fazendo dissertação). Mas como sair dos trilhos? Difícil, não só por falta de recursos próprios, mas porque qualquer desvio de rota deveria ser conduzido com método ou pelo menos indiretamente argumentado. Não, é claro, para atender à armadilha escolar de Aristóteles, segundo a qual falar mal da filosofia ainda é filosofar, arapuca muito rudimentar para apanhar sofista, em torno da qual gira, não por acaso, a gigantomaquia em que se encontram engalfinhados mundo afora partidários e adversários da fundamentação última... Eu ia quase dizendo fundamentação última da filosofia, mas recuei a tempo, em vista da redundância, pois se trata do tipo de questão profissional que só ocorreria, tanto faz se a favor ou contra, às fantasias de abrangência máxima própria da gente filosófica. 
Dito de outro modo, a manobra que redundaria em novo rumo precisaria brotar do interior mesmo da aparência socialmente necessária. No caso em pauta, a cultura filosófica herdada por enxerto, bem-sucedido aliás, e a experiência havida, ou simplesmente ignorada, no decurso de seu funcionamento local, mas nem por isso menos revelador enquanto câmara de decantação involuntária das grandes especulações nas regiões filosóficas centrais. Muito bem. Guardadas todas as proporções, o meu pequeno drama - o que fazer com filosofia, quando não se tem bossa para a alta costura dissertativa? - vinha a ser o apêndice nacional de uma enormidade muito simples, porém difícil de engolir: o que atrapalhava tudo no fundo era o fato de que a filosofia como forma era coisa do passado. Tudo o que veio depois é boato universitário, menos por falta de talento do que por exaustão histórica do gênero. Uma hora dessas ainda vou trocar isso em miúdos e por extenso, mas já dá para ir adiantando alguma coisa.

ICC - Desconfio que já vi esse filme antes. Me pergunto - só pra chatear - se você não está trocando o bolorento Elogio da Filosofia dos discursos de posse em academias e congêneres pelo não menos datado e simétrico Fim da Filosofia, ao qual o último Heidegger deu o acabamento final, entre o sinistro e o demagógico, tão ao gosto dos... Cala-te, boca!

PA - Agradeço a lembrança, sobretudo o propósito limpa-trilhos. Não penso, todavia, estar propondo nenhum sucedâneo igualmente edificante, mas chamando a atenção para a mutação correspondente ao fim de uma maturação histórica. Digamos que o referido desfecho tenha ocorrido ao término de um ciclo inaugurado pela grande novi- dade que foi a obra crítica de Kant, mais exatamente entre a morte de Hegel em 1831 e...

ICC - É difícil não interromper. Você me desculpe, mas também estava pensando em outro filme, aliás reminiscência de cursos seus em meados dos anos 70 sobre a Esquerda Hegeliana pois, se estou bem lembrada, data daqueles anos 30 e 40 do século passado alemão a palavra de ordem superação-da-filosofia. Continuando a lição de casa: superação, de resto, como realização, por sua vez negação da existência em separado da filosofia, além do mais operação mental coextensiva da ideia mesma de Revolução, compartilhada inclusive pelo jovem Marx que de marxista não tinha nada - vinculando uma classe universal apenas virtual ao presumido (por ele mesmo, jovem Marx, autor da expressão) "radicalismo da teoria alemã”. Em matéria de filosofia, não renego nem escondo minha "linha justa": filosofia é falsa consciência de uma sociedade falsa e ponto. Por isso me dá urticária toda vez que ouço algum adorniano pontificando: a filosofia sobrevive porque a promessa de sua realização não se cumpriu, ou seja, já que a Revolução foi à breca, filosofemos. E não me venham com essa de que a Teoria é a verdadeira prática. Podem chamar de ocidental ou do que quiserem, isso nada mais é que marxismo de cátedra, um animal fantástico como os de Borges, o problema é que não é nada inofensivo.

PA - Se você já está querendo entrar na malhação do meu partido, o marxismo ocidental brasileiro, seção Filosofia, ou mesmo Sociologia I, sirva-se. Posso até ajudar. Agora, quanto à substância da sua canelada, toda simpatia. Que o assim chamado marxismo ocidental em má hora rea- 
bilitou a filosofia, é um fato. E por má hora entenda-se a hora pesada do refluxo mundial da Revolução depois da derrota na Alemanha, sem falar no triunfo do stalinismo. Dito isto, não sou jovem hegeliano de esquerda, não estou variando pela enésima vez o tema filosófico do "fim da filosofia”, ele mesmo um teorema (paradoxal, como se vê) de filosofia da história, atuante por exemplo nos frankfurtianos dos anos 30. Basta pensar na constelação marcusiana Razão e Revolução. Tema ainda mais interessante de estudar porque corre paralelo à evolução por assim dizer clandestina (até surgir à luz do dia na virada do século XIX até os anos 20) do ataque vanguardista à dimensão estética autônoma.

MEC - Então tá. Você não está requentando marmita com esse tal de "fim da filosofia". Mas que você começou a entoar essa musiquinha, começou. Vá lá que não seja jovem hegeliano, ou coisa pior, do gênero desconstrução-das-grandes-narrativas.

PA - A propósito: há um lado óbvio nada heroico nessa história de mandar as ditas grandes-narrativas (de emancipação, entenda-se) para a lata de lixo. Quem ignora que não está mais disponível a bela colina da qual Pierre Bezoukov acompanhava o desenrolar da batalha de Borodino? Seja dito apenas para relembrar que as guerras napoleônicas, fazendo a revolução dar a volta à Europa, carrearam para o mesmo molde, o da Narração, romance histórico, historiografia burguesa e filosofia da história. Essa experiência e suas formas aparentadas por certo são coisa do passado. Mas nem por isso o Sujeito Automático na persona do capital-dinheiro financeirizado deixa de totalizar 24 horas por dia. Daí o passa-moleque ideológico de que são vítimas os paladinos da antitotalidade. De resto, capitulam a gosto ressuscitando a figura do filósofo, agora enquanto porta voz do inapresentável-em-desconstrução, e em confronto com o descreditado e quase extinto intelectual universal, para falar como Foucault em guerra com os herdeiros de Sartre. Se chegarmos ao capítulo dos intelectuais, lembrem de Sartre ao defini-lo como alguém que mete o bedelho naquilo que não lhe diz respeito. Aliás, começo o livro (por assim dizer) com a pré-história francesa setecentista desse personagem, no qual por um momento a dialética dos modernos parece cristalizar. Mas isso o leitor já sabe, pois a nossa conversa em princípio é um epílogo.

MEC - Pois então voltemos ao tema antigão, "fim da filosofia”, na variante do Professor aqui presente.

PA - Não sem tempo, desta vez sou eu que o digo. O título nacional da nossa novela era: drama da consciência filosófica profissional. Agora, nos termos da intriga europeia de que somos um apêndice, chamado filosofia universitária francesa transmitida de pai para filho desde fins do século passado, o título do mesmo drama poderia ser assim: fim da filosofia, nascimento da filosofia profissional. Quanto ao enredo deste último, preciso retomar minha fala no exato ponto em que foi cortada: o eclipse da filosofia, reinventada não fazia muito por Kant, transcorreu entre a morte de Hegel em 31 e, justamente, o monumental contravapor de 1848. Já vou adiantando que devemos a Lukács (quer dizer, já vou adiantando e me comprometendo) e mais tarde a Sartre (primeiro no O que é literatura?, de 1947, e mais adiante, de modo sistemático, no Idiota da família, do início dos anos 70) a conversão da Revolução de 1848 em foco de ruminação literária e referência 
filosófica obrigatória. Desnecessário lembrar que em 48 a burguesia triunfante não só se bandeou como massacrou o campo popular já derrotado em todos os terrenos, juntando um crime em escala industrial (que se repetiria em 71 na Comuna de Paris) à vitória político-social. Inútil sublinhar também que o registro magistral desse tournant se encontra numa obra prima insuperável que é o Dezoito Brumário. Pois boa parte do que doravante estará em questão, mesmo nas regiões geladas da filosofia, tem a ver com o estado de sítio moral em que se encontram desde então as classes proprietárias (e massacradoras) descrito naquela primeira e fulgurante análise de conjuntura do colapso da política burguesa natimorta. Portanto, essa reviravolta decisiva afetou muita coisa, não foi só com o destino da filosofia que ela mexeu. O romance, por exemplo, perdeu a ingenuidade épica anterior, e, para não virar simples literatura edificante, precisou, entre tantas outras providências tomadas pelos melhores escritores (Flaubert, em primeiro lugar, mais adiante Henry James), tornar-se tão exigente quanto uma construção poética sem resto, a qual por sua vez também mudou drasticamente (e para melhor, se pensarmos, só para começar, em Baudelaire), do ponto de vista do rigor inegociável, incorporando à pureza da forma o bas fond ideológico da luta de classes. Para a filosofia, entretanto, aconteceu o pior. Ela literalmente ficou sem assunto, perdeu de vez o seu objeto, a integridade do processo. Só que até hoje não sabe disso.

MEC - Quem sabe você se explica melhor, seja dito a título de incentivo.

PA - Era o que eu estava pensando fazer. Retomo o fio por onde tudo começou - a reinvenção kantiana da filosofia moderna. Em linhas gerais, Kant costumava dizer que a filosofia tinha duas dimensões. Numa, funcionava por assim dizer para uso próprio, com terminologia específica, dessas que só se aprende no colégio, cuidando menos do conhecimento do que da sua possibilidade, dele mesmo e do seu objeto possível, coisa mais eminente e complicada. A outra deveria tratar daquilo que a princípio interessa a todo mundo, isto é, de tudo aquilo que tivesse um significado na vida das pessoas. Mas com o tempo e impelido pela arquitetônica da obra crítica, Kant foi relegando a segunda parte e concentrando na primeira o que mais tarde viria a ser considerado o específico filosófico, por sua vez cada vez mais unidimensional, aliás por definição, já que se trata de uma metade, uma fatia do bolo em questão, enfim cada vez mais parecido com a magra dieta escolar dos dias de hoje. Aqui o ponto final para todos nós, pois foi de fato como Crítica do Conhecimento, ou Teoria do Conhecimento (as denominações variam) que na segunda metade do século passado a filosofia se firmou de vez como especialidade universitária, especializada inclusive em questões de demarcação, sempre ameaçada, de um lado, pelo fantasma da extinta metafísica e, de outro, pelo sistema das ciências e algumas novas disciplinas como a psicologia, a lógica formal, as várias epistemologias científicas, etc.

MEC - E a outra metade, a que nos interessa, já que, como você conta, deveria concernir todo mundo? Não é isso que nós vemos por aí quando os filósofos abrem a boca.

PA - Pois é, Hegel sentiu o perigo, o perigo da irrelevância vindoura. É preciso deixar bem claro que ele concordava inteiramente com o teor da renovação kantiana, afinal 
a Idade da Crítica chegara para ficar, ela era a essência mesma dos Tempos Modernos e estes eram irreversíveis. Mas achava, não obstante, que a Crítica do Conhecimento - aquela reflexão dita transcendental, anterior a todo conhecimento efetivamente exercido como tal, como quem se aquece antes de entrar na água mas se esquece e acaba ficando mesmo nesses exercícios preliminares - exercida assim em separado, além de altamente problemática - um círculo vicioso, esse conhecimento anterior a todo conhecimento, espécie de saber negativo na forma de uma ciência dos limites - era também inócua e como tal poderia acarretar um dano irreparável à verdadeira inteligência filosófica. O problema dele vinha a ser então o seguinte: descartado qualquer retrocesso dogmático, nem pensar em restaurar, tal qual a velha metafísica, a inocência dos juízos sintéticos em torno de objetos inexperimentáveis (motivo a mais para modificar pela base a noção de experiência, diga-se de passagem); a razão deveria sem dúvida pôr à prova os seus conceitos puros, submetê-los ao teste da objetividade possível, em suma criticar-se, mas não poderia executar tal tarefa crucial de costas para o mundo, sob pena de esterilizá-la.

Alguém observou certa vez que Kant trouxera a filosofia da idade ingênua para a sentimental. Com o que Hegel concordava inteiramente, embora não empregasse explicitamente a divisão schilleriana entre o ingênuo e o sentimental. A ressalva que acabamos de repassar é tanto mais premente quanto os pós-kantianos, filósofos e poetas, estavam entendendo o sentimental como reflexão pura, no sentido de que o único assunto da filosofia é a própria filosofia. (Vale o curto-circuito: até hoje só é considerado filósofo profissional, isto é, filósofo propriamente dito, quem cuida de filosofia, e isto de um ponto-de-vista-lógi- co, lógico-transcendental para ser mais exato, ou o que passe hoje por transcendental. A cultura filosófica franco-uspiana está aí para não me deixar mentir, e me obrigar a acrescentar ato contínuo que não há nada para pôr no lugar dessa descendência em linha direta da primeira dimensão kantiana exclusiva e que possa ainda ser chamado de filosofia ou coisa que o valha. E se em vez de "cuida" de filosofia eu tivesse dito "estuda" filosofia, estaria simplesmente lembrando que a matriz profissional admite - e como! - uma filial historiográfica, embora seja esta movida muito mais a filologia do que a problemas filosóficos em busca de solução, salvo no caso específico da retomada dos clássicos pelos filósofos analíticos.)

Mas então o que exigia Hegel? Não só que se reconhecesse enfaticamente que as duas dimensões eram inseparáveis, mas sobretudo que se deveria falar de uma nos termos da outra. Da totalidade da experiência, cujo sentido a ser decifrado e narrado interessa a todo mundo, nos termos das categorias criticamente expurgadas de sua ganga dogmático-metafísica, e vice-versa: o encadeamento lógico das formas nos termos do processo histórico havido. Ora, o que é essa exposição única, porém em mão dupla, senão a Dialética em pessoa? Uma analogia para facilitar, mas apenas uma analogia: juntas e redivivas, a visão sinóptica platônica e o debate contraditório aristotélico conduzido numa terra de ninguém lógica, pelo cidadão qualquer simplesmente cultivado. Analogia que se poderia estilizar em termos modernos assim, por exemplo: onde havia visão sinóptica propriamente metafísica, devemos falar agora de diagnóstico de época ou de ponto de vista da totalidade, e no lugar do cidadão que argumenta "dialeticamente" com as armas que a cultura não especializada lhe faculta, a reflexão "sentimental" da 
consciência moderna raciocinante que não se deixa mais embair pelo fundo falso do meramente positivo. Assim, o que cabia ao filósofo enquanto tal - na acepção hegeliana terminal da palavra - dizer, por exemplo, sobre Arte, Sociedade, História, Direito, etc. não poderia ser nunca rapsodicamente arbitrário, porém tampouco preceptivo: o curso do mundo não precisou esperar pela filosofia para saber afinal o que é ou deve ser o Estado, por exemplo. Além do mais, sendo assim obrigatória a circulação entre os dois planos, a exposição assume a forma de uma crítica imanente, quer dizer, o conteúdo exposto à luz do dia carrega consigo o seu próprio termo de comparação, com o qual a sua verdade será confrontada, sucumbindo se não sobreviver à prova da sua contradição, que é sempre interna. Como estou entre moças de fino trato literário, posso arriscar sem medo: vocês não estão se sentindo um pouco em casa?

MEC - Já andava meio desconfiada, estava mesmo farejando um certo arzinho de família. Você quer que a gente reflita um pouco para ver se à luz do exposto fica mais compreensível o fato muito pouco compreensível de que se deva a um filósofo idealista, e ainda por cima alemão, uma das primeiras teorias do romance como gênero narrativo realista e burguês? Já que estamos falando nisso, faça o favor de nos explicar o que o Bento Prado quis dizer lembrando que você modestamente chegou a cogitar de uma espécie de réplica filosófica da Mimesis do Auerbach. Bom, o que o Bento quis dizer deu perfeitamente para entender, aliás ele até que salvou a sua cara. Mas e o senhor?

PA - Daqui a pouco posso tentar me explicar e já vou registrando e agradecendo a deixa que a Iná deixou escapar.
ICC - A esta altura, também entreguei minha alma a Deus, como fez o Sterne depois de escrever a primeira frase.

PA - Para chegar na Mimesis, preciso lembrar certos pontos que estavam de fato no meu caminho, pois ele também não deixa de padecer do mesmo abalo sísmico que derrubou a última filosofia. Agora, a observação de há pouco me ocorreu enquanto falava ao pensar no raciocínio de um crítico literário lukacsiano estrito, cujo modelo sabidamente era o grande realismo do romance europeu oitocentista, ao afirmar que a coerência construtiva de uma obra realista, a qual principia pela matéria bruta das noções comuns que discrimina e retifica ao longo do seu curso, se resume ao modo pelo qual o jogo das categorias assim mobilizadas passa juízo sobre si mesmo. Gosto muito desta última fórmula e acho que nela se pode reconhecer o que estávamos vendo a respeito da exposição filosófica em chave dialética como autocrítica imanente. Quer dizer, a crítica literária materialista também é por definição incompatível com a chamada reflexão externa condenada por Hegel na posição do observador que julga segundo critérios extrínsecos. Contudo o picante da história onde queria chegar é o ponto desse raciocínio lukacsiano em que o crítico sugere que o romance realista procede como a Crítica da Economia Política.

MEC - Troque em miúdos: não podemos deixar passar em branco essa simpática enormidade!

PA - Vou me esforçar. Recapitulo, pois nisso também está em jogo o destino da finada filosofia e, portanto, os azares da nossa atual consciência profissional prejudicada. Hegel, portanto, chegara à seguinte conclusão, se é que dá 
para falar assim, à maneira do famoso bêbado de Diamantina pedindo contas aos filósofos ali reunidos em congresso: a filosofia não tem propriamente um objeto específico, um assunto próprio, um conteúdo doutrinário qualquer, uma mensagem a transmitir, um pensamento que seja, algo a dizer sobre o mundo ou coisa que o valha. Isso posto, ela nunca foi tão exigente e abrangente como naquele momento terminal, já que o seu negócio, como acabamos de ver minutos atrás, vem a ser nada mais nada menos que a experiência presente na sua totalidade, um resultado histórico-categorial a que podemos chamar mundo (experimentado) e por ela elevado ao plano do Conceito (para empregar o termo "técnico" preferido por nosso filósofo). Diagnóstico de época, em suma, só que lavrado por extenso em termos conceituais logicamente concatenados, como se disséssemos, na filosofia, na Teoria em sua acepção mais enfática, uma época se pensa a si mesma, se enuncia a si mesma no momento em que toma consciência de si ao narrar retrospectivamente o seu vir-a-ser. E assim por diante, tendo sempre presentes as duas dimensões, as duas metades em questão, mais a reversibilidade entre ambas na forma negativa da crítica imanente, porém assentada em bases essencialmente otimistas, pois dá-se como favas contadas que, tal como a consciência, o mundo é o seu próprio conceito, portanto uma totalidade dinâmica a caminho da sua adequação interna ou reconciliação na acepção por assim dizer salvífica da Teoria. Duas metades, quer dizer: razão dos dois lados (subjetiva e objetiva), reflexão dos dois lados, lógica dos dois lados, experiência dos dois lados, história dos dois lados, e por aí afora.

Bons tempos (para a profissão) em que o curso do mundo podia se apresentar na cifra de um juízo sintético a priori. Curso do mundo muito recente enquanto tal, algo que brotara e tomara a sua forma atual com a Revolução Francesa, com a Revolução Industrial, com a Sociedade Civil enquanto arena de mediação do particular pelo universal, etc. Deu-se afinal o grande revertério de 1848. No plano que nos interessa, o princípio do colapso da cultura burguesa, um processo de longa duração, quase um século até seu desfecho em 1933. Assim, a bem dizer sem aviso prévio (ou melhor, com um sinal precursor: com a Revolução Francesa de 1830, Hegel pressentiu que as coisas não andavam bem para uma filosofia que pela primeira vez, ao contrário de suas congêneres, devia passar pela prova dos acontecimentos), de um só golpe (o que de fato ocorreu com o segundo Dezoito Brumário), o chão histórico dessa visão dupla - sobre o processo na sua integridade, é bom não esquecer, para o momento do confronto com os sucedâneos vindouros - visada dupla que vinha a ser a filosofia em seu fastígio histórico-mundial (para voltar a falar como a esquerda hegeliana, os primeiros a sentir o contravapor e a desconfiar de que, se persistissem, acabariam falando sozinhos), pois esse chão histórico basculou e as duas metades em questão se separaram para sempre, pouco importando as amarrações emergenciais subsequentes. São panaceias e nada mais, pois aquelas duas dimensões identificadas por Kant no limiar do renascimento filosófico contemporâneo foram apartadas uma da outra pela luta de classes (coisa de que os artistas logo se aperceberam, enquanto os filósofos, na sua incuriosa sobrevida, passaram inocentemente ao largo), pela modernização capitalista, pelo progresso das ciências (sobretudo na acepção fetichista do bordão), pelo retrocesso social, pelo mal-estar na cultura burguesa, etc.

Como já vimos, a primeira metade, que ainda preservou o nome de filosofia (profissional, está claro), foi inape- 
lavelmente (aliás, com pleno consentimento, penhor de respeitabilidade científica) apanhada na rede da divisão institucionalizada do trabalho intelectual, e sempre que resolve entrar em cena fala em nome da lógica, da epistemologia ou coisa que o valha, espécie de mimetismo irrisório da antiga preeminência da Crítica kantiana exercida em separado. Mas quem acredita ainda que lhe caiba como antigamente (e olhe lá) a última palavra sobre todos os assuntos, a começar é claro pelo que verdadeiramente importa, por aqueles que interessam a todo mundo?

Não sei de exemplo mais lamentavelmente patético dessas mancadas da filosofia em regime de sobrevida inconsciente, porém profissional do que a última (ou a primeira?) intervenção pública de Husserl, uma conferência de meados dos anos 30, A Filosofia e a Crise da Humanidade Europeia. Pressentindo o pior naquela década mais do que sinistra, Husserl encontrou energia para um derradeiro diagnóstico de época, como era do dever de um verdadeiro filósofo, autodesignado funcionário da humanidade, só que do ângulo próprio da outra metade que cultivara em separado a vida inteira, e era mesmo de se esperar da parte de um professor alemão de filosofia, paladino da cultura teórica em estado quimicamente puro. Numa palavra, a humanidade estava em crise e corria para o abismo (o que já era até enxergar demais, se pensarmos no seu não menos famoso sucessor na Universidade) por excesso de "objetivismo". Entendamos, um efeito do esquecimento da pureza desinteressada da Teoria e sua capacidade de abrir horizontes para o progresso infinito do conhecimento não objetivante, daí o antídoto prescrito in extremis: a restauração da Razão Pura Teórica por intermédio da reflexão fenomenológica radical. Como disse, é difícil encontrar nestas proporções dramáticas exemplo mais eloquente de inépcia filosófica, e não por falta de talento, afinal se trata de Husserl, mas por se tratar de gênero historicamente sucateado faz tempo. Mutatis mutandis (não muito aliás), não por acaso Habermas vem esgrimindo as patologias do capitalismo tardio com as armas da Razão Prática restaurada e trocada em miúdos comunicativos. Filosofia é isso.

Em compensação, qualquer militante operário sabia perfeitamente àquela altura a quantas andava o mundo, mesmo que uma boa fatia dos quadros dirigentes do movimento revolucionário internacional tenha começado a desatinar desde os fins da década anterior e que a classe operária tomada em bloco já não fosse mais caução automática da boa simbiose entre conhecimento e interesse. Basta, no entanto, o exemplo de um simples articulista de imprensa, digamos, spartakista. A famosa (para nosso uso interno) integridade do processo costumava passar por inteiro em sua coluna, porém nem sombra do mesmo numa descrição fenomenológica e seus derivados transcendentais. A explicação se encontra na enormidade com a qual há pouco simpatizava a professora Maria Elisa. É que na decisiva rotação de eixo da luta de classes em 1848, o famigerado ponto de vista da totalidade mudou de vez de campo.

MEC - Quer dizer então que o nosso Professor aqui está na bica de ressuscitar, ou inventar ad hoc uma espécie de hegelianismo popular?

PA - Não seria má ideia. Aliás, primeiro Lênin, depois o Brecht, bem que pensaram num clube de amigos materialistas da dialética hegeliana, o que é outra coisa também da maior utilidade. Mas eu não estava nem de longe 
pensando em tamanho disparate. O que estou querendo dizer é que as duas metades ou dimensões que compunham a filosofia no seu fastígio hegeliano, e que foram drástica e irreversivelmente deslocadas pela guerra social declarada de 48 , se recompuseram no campo popular não na forma de uma filosofia alternativa, porém na forma (materialista) de uma Crítica (imanente) da Economia Política. Digamos que O Capital livro - e suas incontáveis ramificações (uma peça de Brecht, por exemplo, para não falar de modo ainda mais escandaloso num conto de fadas kafkiano) - passou a tratar no seu modo expositivo bidimensional justamente daquela totalidade que interessava a todo mundo. Ali todas as categorias passam juízo sobre si próprias na medida mesma em que vão deixando pelo caminho da crítica imanente o mais abrangente diagnóstico de época disponível até o momento, mesmo, ou sobretudo, depois da queda.

Será preciso insistir? Pensando bem, acho que sim. Não se trata nem dos fundamentos filosóficos do Capital, que tem passado muito bem obrigado sem isso, muito menos - se possível, coisa pior ainda - de um corpo doutrinário filosófico a rivalizar com o similar destilado no campo da ordem. Conhecemos a primeira hipótese. Ela tem a ver com a transformação do marxismo num novo Discurso do Método por obra e graça do assim chamado marxismo ocidental. A segunda hipótese também se realizou e culminou num monstrengo chamado marxismo soviético, Diamat e que tais. Mas para chegar até aquele fim de linha, desceu o plano inclinado de uma espécie de filosofia espontânea do movimento socialista, para a qual até Engels contribui. Por isso falei em Crítica da Economia Política, que não só não carece de fundamentação filosófica, nem é matriz de uma outra filosofia proletária sucedânea, mas sobretudo pode e deve lançar alguma luz retrospectiva sobre o passado da ilusão filosófica anterior, que se revelou tal por não poder mais prosseguir adiante. Assim, o fetichismo da mercadoria, sendo metafísica real, esclarece o ponto de vista lógico dos filósofos, e não o contrário. Ora, o que é interessante notar em toda essa contradança desfechada pela fratura de 48, quando as classes proprietárias passam para a defensiva e a Aufklärung muda de sinal? É que com esse tournant a filosofia como gênero - o que deveria tocar de perto o coração de um uspiano desabou por igual e sem deixar resto nos dois campos da guerra das classes. Ou melhor, deixando justamente restos num e noutro campo. Com os quais continuamos a nos alimentar, universitários e militantes, pois não foi pouca coisa o lixo ideológico que sobrou desde então, periodicamente reciclado.

Deixemos descansar em paz o finado Diamat. Interessa mais nossa própria árvore genealógica, a fraseologia filosófica pós-48. Decapitados pela força das coisas os dois pilares que sustentavam o edifício filosófico do mundo-transposto-em-conceito, este último refugiou-se na universidade sob o nome epistêmico de Teoria do Conhecimento, primeiro capítulo de uma evolução que depois de incorporar, na virada do século XIX para o XX, ao veio do criticismo kantiano, a virada semântica da lógica moderna, na forma de uma teoria da significação em torno da qual giram mente e linguagem, acabou desaguando na atual virada pragmática das mais variadas procedências, enquanto o extinto diagnóstico de época, entregue a si mesmo sem o momento forte da Teoria, foi sendo fatiado nas diversas ciências sociais, depois humanas. Isto quanto ao sistema positivo das especializações metodicamente enraizadas nas instituições universitárias. 
Por fora corria uma outra casta filosofante, desde as últimas décadas do século passado alimentando-se igualmente das sobras daquele processo cuja inteireza precisou ser escamoteada, já que passava sob nova denominação para o outro lado onde vigorava como o ponto de vista de uma classe revolucionária - pelo menos até a época em que o trânsfuga Lukács finalizava História e consciência de classe. Enfim, uma forma abastardada do antigo interesse pela totalidade circulava nas mais variadas filosofias disso ou daquilo: vida, vontade, existência, inconsciente, cultura, história, linguagem, espírito, amor, moral, sexualidade, música, intuição, religião, etc., etc. Um arco-íris ideológico, do mais rasteiro beletrismo filosofante ao mais negro niilismo de bom-tom, mais tarde apologia indireta de certas vanguardas da transcendência vazia. Está claro que o menos interessante nisso tudo se encontra nessa falsa dissidência de classe, que conjuga um belo ódio ao burguês vencedor e igual ódio pela impotência gerada por esse mesmo confronto no vácuo. Essa a mola nada secreta dessas filosofias extracurriculares, um certo mal-estar na cultura que cristalizou o estado de sítio moral em que passou a viver a consciência burguesa em luta com o fantasma do oponente que ajudou a massacrar. O caso Nietzsche é o mais extraordinário desses jogos de prestidigitação: até hoje não se pode deixar de admirar a destreza com que metamorfoseou, alegando a mais radical Kulturkritik, a haine de soi dos predadores de cima em ressentimento das classes subalternas ruminando vingança pelo esbulho sofrido. Pois desse arco, do mais róseo ao mais sombrio foram brotando visões de mundo, como se começou a falar então.

Ora, com o progresso da modernização capitalista ajudando, deu-se então novo disparate, do qual vivemos até hoje em nossa desconfortável profissão: a filosofia se recompôs, rejunte espúrio, é claro. Só que agora na forma de uma nada curiosa divisão do trabalho, pois é assim mesmo que se combinam no mundo ordenado pelo capital o cálculo econômico de meios e fins e a flutuação das crises dessa mesma racionalidade econômica no âmbito maior da evolução do sistema. De um lado, portanto, a mesma dimensão epistêmica de origem (kantiana, para abreviar), a crítica ou análise lógica como profissão, sob a égide da teoria, do outro, a segunda dimensão também de origem, como vimos, movida a decisões hermenêuticas irrecorríveis acerca do significado último da existência tomada em sua totalidade. Enfim, justaposição de juízos de conhecimento (para falar genericamente) e visões inefáveis do mundo. Consciência profissional na hora do expediente comercial, amálgama de poesia e metafísica da happy hour em diante. Restauração bastarda da falsa inteireza do processo a que se resumia antigamente a substância filosófica da vida teórica, muito clara por exemplo na reversibilidade muito característica de racionalismo e mística no Tractatus de Wittgenstein, amálgama de especulação sobre o sentido da existência e investigação dos limites lógico-transcendentais daquela mesma especulação, confinada então ao conflito silencioso com o miolo ético da totalidade que em princípio concerne todo mundo, como no passo antigo da Teoria à vida boa. Uma contrafação que é da natureza mesma do processo moderno, mais a pitada de vanguardismo das proposições autodestrutivas, como uma máquina Dada.

Esse casamento profissional entre as duas metades pré-48 simplesmente justapostas vem se reproduzindo regularmente desde que o gênero se firmou, com a tônica universitária recaindo de preferência no ramo epistêmi- 
co-historiográfico do conjunto, sem é claro fechar a porta para a interpretação do sentido da experiência na sua totalidade. Para dar exemplos que costumam impor respeito: o que vem a ser o assim chamado (por Habermas) Discurso Filosófico da Modernidade senão uma restauração por assim dizer protocolar do sistema hegeliano de vasos comunicantes entre racionalidade comunicativa e legitimação da Idade Moderna uma vez encerrada a era das filosofias da história? À vista dos atuais desmandos do capitalismo mundializado, escusado lembrar que a Crítica da Economia Política ainda teria voz mais forte nesse capítulo outrora filosófico, mesmo que o filósofo, confiando na normalidade capitalista de anteontem, diga que a crise não é mais de caráter sistêmico, mas está confinada às questões normativo-culturais de legitimidade. Até mesmo Foucault, lá para o fim da vida, recordou-se daquela bipartição na origem do (verdadeiro, pelo menos historicamente) Discurso Filosófico da Modernidade, evocando a extração bifronte das cogitações filosóficas desde o tempo em que Kant, um pouco antes de Hegel, se impôs a tarefa de "pensar" a Revolução Francesa enquanto cifra da Ilustração em progresso: de um lado, nos termos de Foucault, uma Analítica da Verdade, de outro uma Ontologia do Presente. Dito isto, algum sexto sentido lhe sugeriu que era uma coisa ou outra, reconheceu que lhe caía melhor a segunda alternativa e mergulhou ato contínuo na panaceia deste fim de século, a estetização da existência numa estilística individual fazendo as vezes de diagnóstico de época, versão um pouco mais libertina da visão moral de seu confrade alemão Habermas. Evasão neopragmática americana da filosofia profissional? Não seja por isso. A revogação da velha ilusão filosófica fundacionista não implica nova clarividência acerca da unidade do processo em curso. É justamente o contrário: acarreta uma espécie de nova euforia fetichista pela mesmíssima divisão do trabalho ideológico de sempre. O que se passa no centro do Império no domínio filosofante das cogitações de alto bordo? Instituições liberais bem planejadas, e tão bem planejadas que dispensam programaticamente qualquer tipo de legitimação essencialista, aureoladas por uma espécie de expressivismo do self de origem tardo-romântica, réplica highbrow do multiculturalismo pop, ambos cifras aviltadas da experiência totalmente fetichizada. E assim por diante, no quartel da consciência filosófica profissional. Uma coisa é certa: não dá para continuar burocraticamente repartindo tarefas, de um lado, a filosofia como lógica, ou epistemologia, ou teoria da mente, ou filosofia da linguagem e por aí afora; do outro, igualmente bem estabelecida no ramo, a filosofia como Crítica da Cultura - e estamos conversados, e em muito melhor situação se ainda por cima reunirmos as duas metades originais sob a rubrica filosófica de sempre. Não estamos conversados coisa nen huma. Juntas ou separadas, a primeira continua inócua (sem a segunda, à qual não pode mais se reunir), enquanto a segunda, nos dias de hoje, em que não sabemos mais onde ancorar a Crítica e desenvolvê-la por extenso, tornou-se pura conversa fiada sobre cultura sob o nome de Crítica Cultural, e seus assemelhados nos diversos idiomas em curso nos colóquios internacionais. Como ficamos? Lembro que ainda estamos a caminho do quefazer filosófico brasileiro, uma encrenca que deveria atrapalhar a vida filosofante de quem não tem bossa dissertativa.

ICC - Estou pensando em complicar sua vida por mais um tempo. Isto é, estou me perguntando se você repassou to- 
dos os modelos relevantes para demonstrar de uma vez por todas a exaustão histórica do gênero filosófico, exaustão verificável nos dois campos em guerra social desde a primeira vitória da contrarrevolução em 1848: nem filosofia profissional burguesa, nem filosofia proletária. Já devo ter dito aqui, mas não custa repetir: na condição de brechtiana de carteirinha, estou me lixando; aliás, como já foi frisado há pouco, se não me engano, a velha filosofia no seu fastígio não deixa de estar presente em nosso Bertolt Brecht, onde não faltam nem uma certa poesia do pensamento enquanto tal, nem o diagnóstico de época na forma de configuração artística da totalidade do curso do mundo. Isto posto, cabe a pergunta: e História e consciência de classe? E a intenção filosófica da antiga Teoria Crítica frankfurtiana, muito diferente da versão escolar de Habermas \& Cia? Como dei uma trombada faz algum tempo no Adorno ideólogo da forma-ensaio, fico de olho nas respostas dele à pergunta clássica "por que, ainda, filosofia?”. E por fim: a certa altura, a propósito do intelectual como alguém que fala do que não é da sua competência, você mencionou o Sartre. Como ele fica nessa novela toda da sobrevida fantasmagórica da filosofia?

PA - Você não quer pouca coisa. Como diz o outro, vamos por partes. Em primeiro lugar, reservemos o Adorno "ideólogo" do Ensaio-como-Forma, como você mesma disse, para mais adiante. Quanto mais não seja, porque no livro de que ainda não conseguimos falar ele também funcionou um pouco como ponto de fuga.

Comecemos pelo Lukács dos anos 20. É sempre uma revelação reler História e consciência de classe, mas obviamente se trata de um modelo irrepetível, de um livro escrito num momento de estado de graça histórico, em que a Revolução ainda estava na ordem do dia. Daí um sem-número de proezas, hoje literalmente impossíveis, como utilizar no seu campo próprio as armas do adversário, mais especificamente a filosofia clássica alemã, antes da queda, e a sociologia alemã da modernização (Weber), esta depois da queda. Isto ao perceber que filosofia materialista-popular deveria ser mesmo um disparate - daí a condenação subsequente, mas não só por isso. Por suposto, sua matriz é a Crítica da Economia Política e não mais a Filosofia, tradicional por definição. Dito isto, foi o primeiro e o último a poder juntar, com evidente apoio na realidade, os dois elementos constitutivos do marxismo, o momento dinâmico da revolução socialista em marcha e a crítica do fetichismo da mercadoria presente na "objetividade" petrificada da relação da consciência com o mundo moderno.

No imediato pós-guerra, senão antes, esta exposição de mão dupla já estava fora de combate, tanto é (assim lhes parecia) que aos poucos os frankfurtianos históricos foram se atendo unicamente à segunda parte, convencidos de que uma simbiose demoníaca entre desenvolvimento das forças produtivas e relações sociais de produção, congelando a Revolução, deixara disponível apenas a porta estreita da crítica materialista da alienação.

E a Filosofia, que é o que nos interessa enquanto gênero pretérito, artificialmente redivivo no Brasil da cultura universitária transplantada? Posso dizer que Lukács soube fazer render o seu fim, dela, filosofia, para falar de uma maneira um tanto filistina. Ignorou 48. Não sem paradoxo, pois sendo o primeiro a identificar aquele episódio na história da desintegração da cultura burguesa, irá fazê-lo no momento do retrocesso stalinista ao mesmo tempo em que reabilitará no campo "proletário" (na falta de melhor 
termo) a filosofia tradicional na forma de uma Ontologia, do Social ao Estético, com direito à valorização de Nicolai Hartmann e tudo.

Mas voltemos. Acho que cheguei a lembrar que o tema jovem hegeliano "fim da filosofia" - que em absoluto não é o meu, insisto - entrou na ordem do dia acompanhado de uma palavra de ordem correlata, a saber: realização da filosofia, entendida como negação de sua existência em separado, negação visada por sua vez como o trampolim de uma emancipação, no caso, de uma das figuras da vida alienada de si mesma, cindida por uma mediação imaginária. Se não me engano, também devo ter dito que, a ser assim, o motivo "fim da filosofia" teria que ser tomado como um enunciado filosófico, ainda que o último deles, como o derradeiro teorema de uma filosofia da história, além do mais, como seria de se prever, de cunho hegeliano estrito, não que fosse esta especificamente a filosofia hegeliana da história, mas por encarnar aquilo mesmo que segundo Hegel, como vimos, se deveria entender por filosofia. O que fará Lukács mais adiante, em HCC: o que é a atualidade da presente época histórica elevada ao plano do conceito senão a Revolução?

Mas, retomando o fio. Concebida nestes termos, uma filosofia da história gira em torno da ideia objetiva de Razão. Necessito agora fazer uma breve exposição, inclusive para que a gente possa apreciar melhor a imensa distância histórica que nos separa do último filósofo, justamente derradeiro por se encontrar no limiar da chamada Modernidade, não me cansarei de insistir. (Outro parêntese: só daria para entender um Discurso Filosófico da Modernidade como uma narrativa das várias figuras dessa impossibilidade, e não como a sua legitimação filosófica em novas bases, a meu ver apologéticas, já que correríamos pelo trilho da normalidade capitalista que pelo menos há duas décadas deixou de sê-lo com o fim da regulação keynesiana).

Razão para Hegel não é mera faculdade de conhecer, ainda que superior. Já lembrei que ela se encontra dos dois lados, e isto quer dizer, entre outras coisas (como sustentar que há reflexão nos dois polos que imantam a exposição propriamente filosófica), que ela é a um tempo teórica e prática, operando, portanto, a junção de sujeito e objeto em todos os níveis. Assim, ela não só fundamenta a possibilidade de juízos sintéticos a priori, unificando universal e particular, como reconcilia praticamente sujeito e objeto. E reconciliação quer dizer emancipação, superação de um antagonismo. (Pensemos no dinamismo específico envolvendo indivíduo e sociedade no grande realismo literário, e não só nos romances de formação.) De sorte que de um conceito assim tão enfático e substantivo de Razão é natural esperar que implique igualmente as noções também substantivas de justiça, liberdade, felicidade, etc. (O que Hegel viu muito bem no processo multissecular de emancipação-formação pelo trabalho que culmina na Revolução Francesa.) Sendo sinônimo de subjetividade emancipada, autônoma, realizada, soberana, a Razão é a cifra mesma da Aufklärung, da autorreflexão da certeza subjetiva, do sujeito que finalmente se sente em casa.

Novo parêntese. Estou dando de barato que a Dialética da Aufklärung ganharia em precisão histórica se não corresse unicamente pelo trilho um tanto inespecífico da longa duração que da Odisseia a Auschwitz interverte em permanência progresso e retrocesso, liberação e sujeição; ou pela pista apenas formal derivada da constatação de que a modernidade ilustrada gera patologias que não podem ser erradicadas por providências de caráter tradi- 
cional, por panaceias conservadoras, pré-modernas, isto é, que o sujeito moderno carece de regras que o orientem e estas não estão mais garantidas pela tradição, o que redundaria em rebater a Dialética numa espécie de axioma sociológico trivial. Isto é, ganharia em precisão se conseguíssemos escandi-la através da periodização da própria expansão capitalista, pois não é outra a substância material da Aufklärung, a menos que prefiramos nos deixar ofuscar pela enésima vez pela ilusão ilustrada ou alguma outra visão moral do mundo capitalista contemporâneo. Assim sendo, continuo insistindo em que o primeiro epicentro da dita Dialética da Ilustração se encontra no olho do furacão às avessas de 48, data magna da bancarrota a caminho da cultura burguesa. Até Nietzsche sabia disso, sua força vem daí.

Retomando. Razão para Hegel era além do mais outras duas coisas também: o mundo moderno se institucionalizando graças a um sistema de mediação entre Estado e Sociedade Civil, a convicção portanto de que uma razão substantiva era imanente à nova ordem burguesa emergente; sendo ao mesmo tempo equivalente, ela, essa razão objetiva, a algo como uma sociedade não-antagônica, reconciliada nos moldes da identificação mediatizada (pelo trabalho e pela linguagem) entre sujeito e objeto, síntese que havia escapado às filosofias transcendentais que o precederam. Aqui o nervo da dialética viva, o cimento da convergência entre Crítica e Filosofia (na dupla chave desta última), que vem a ser a mola secreta da Negação Determinada ou, se preferirem, futuramente Crítica Imanente ou Ideologiekritik, um esquema desenvolvido por Hegel desde os seus primeiros escritos sobre a ideia de Positividade, mais adiante Alienação: é que essa Razão bifronte porque substantiva é ao mesmo tempo conceito e reali- dade, podendo assim ser confrontada com o seu próprio conceito ou, ainda, elevar o seu tempo ao plano do pensamento. (Mais para o fim da vida, Hegel irá laminar o momento negativo dessa noção de Crítica: criticar vem a ser apenas denunciar os equívocos dos que teimam em não se reconciliar com os Tempos Modernos, desfazer falsas representações que se interpõem entre a consciência e o curso do mundo.)

Quando a esquerda hegeliana a bem dizer acelerar a cristalização da noção de ideologia, exigindo por via de consequência que se apresse por assim dizer o fim da última filosofia por uma espécie de dessublimação daquela esfera cultural autônoma, estava a rigor dizendo o seguinte: Hegel só é falso, e com ele toda a filosofia que bascula assim no domínio ideológico da falsa consciência, na medida em que afirma que a Razão já está realizada, que portanto já vivemos numa sociedade não-antagônica, em que indivíduo e universalidade já se encontram reconciliados na mediação recíproca de um pelo outro. Estava armado assim o modelo para a Crítica da Economia Política enquanto "negação determinada": a teoria do valor-trabalho nada mais era do que uma pergunta, irrespondível sem contradição, dirigida ao capitalismo nos seus próprios termos, a ver se a sociedade burguesa correspondia ao seu próprio conceito. Já sabemos quando e por que o ponto de vista da totalidade (que é o ponto de vista desta última pergunta pela equiparação entre o real e sua ideia) mudou de campo.

Mas não é este o ponto agora, e sim alcançar História e consciência de classe, se é que ficou claro pelo exposto que no livro ainda podemos surpreender em ato essa filosofia da história inerente ao longo processo de desintegração da filosofia, na sua acepção mais enfática. Aliás Lukács 
descreve essa fuga para a frente da filosofia tradicional, isto é, propriamente dita, na busca da identidade sempre diferida entre sujeito e objeto. Não surpreende que nessa procura ela vá se enredando em antinomias cada vez mais inextrincáveis, aureoladas por uma guirlanda de filosofias-visão-do-mundo, panaceias restauradoras de uma totalidade que mudou de foco e de lugar conforme girou no seu eixo a luta de classes e a generalização das relações mercantis, como já sabemos e Lukács naquele momento reconstitui noutros termos. Como leu muito bem Max Weber, sabe que com a generalização do cálculo econômico e a consequente formalização das relações sociais, que reinterpreta nos termos da reificação que o fetichismo da mercadoria deixa alastrar como um tétano, sabe portanto que já não se pode mais confiar inocentemente no trabalho de toupeira da razão objetiva, cuja substância formalizando-se definha rumo à alienação total da experiência da qual a humanidade só escapará graças à reviravolta in extremis da Revolução Proletária: é que com o proletariado, e o seu partido, irrompe um ponto de vista em que retorna a Razão Objetiva, a Totalidade de sentido visada pelo sujeito-objeto idêntico dos filósofos cristalizado agora na classe operária revolucionária.

De sorte que o sentido e a liberdade banidos pelo ímpeto formalizador e burocratizante da ratio burguesa descrito com frieza iluminista por Weber (devidamente amparada no correspondente decisionismo existencial, último recurso numa sociedade devidamente desertificada) retornam por uma subversão final que ao emancipar a sociedade torna novamente o mundo narrável - e a filosofia enfim definitivamente dispensável. Por onde se vê que a frágil sobrevida desta última, evoluindo meio clandestinamente no campo proletário, se dá em forma de uma filosofia da história e que esta está centrada num conceito substantivo de Razão socialmente existente e apreensível criticamente na modalidade de uma "negação determinada”. Ora, essa derradeira constelação filosófica entra em colapso quando se eclipsa o potencial racional historicamente realizável da sociedade burguesa. Continuo insistindo que a primeira síncope se deu em 1848, obrigando a negação determinada a mudar de campo e de pele, convertendo-se em Crítica da Economia Política.

De um outro ângulo, vejamos de relance o seguinte cotejo: já estamos nos anos 30, esqueci de avisar, achando que não precisava, nas fileiras marxistas mais exigentes (os frankfurtianos históricos), intelectualmente mais exigentes, entendamos (afinal eram mandarins egressos da universidade), quando então engatinhava o futuro marxismo ocidental, História e consciência de classe já era considerada, juntamente com a Revolução que ela tentara pensar em termos "filosóficos", uma obra-prima do passado, o proletariado idem, mesmo assim ainda saltava à vista a patética irrelevância de um dos termos no confronto a que aludi e agora especifico: do lado profissional da filosofia que ignora o próprio passamento, fenomenologia transcendental ou existencial, tanto faz (que esta última variante tenha desepistemologizado a primeira enquanto lógica do conhecimento), a que se juntava o irmão gêmeo neopositivista; do outro lado, àquela altura já podemos dizer híbrido, a meio caminho do Instituto de Pesquisa e do Partido revolucionário organizando o vínculo entre teoria e prática no ritmo da luta de classes, do outro lado quand même, ainda em uso uma filosofia da história nos moldes de uma Ideologiekritik, tendo no horizonte conteúdos históricos a realizar, claro que redefinidos nos termos da teoria do valor-trabalho e da correspondente 
crítica imanente da alegada troca de equivalentes na esfera da produção, numa palavra, ainda em disponibilidade uma ideia enfática de Razão cristalizada no conflito entre o potencial "racional" das forças produtivas e as relações sociais de produção - enfim, Metafísica aos olhos da ascese profissional do campo adverso. No início dos anos 40, até mesmo este epílogo filosófico tinha deixado de convencer: certos de que o capitalismo totalmente administrado eclipsara de vez suas virtualidades racionalmente produtivas, aqueles mesmos frankfurtianos históricos já não conseguiam encontrar uma lugar fora da engrenagem a partir do qual se pudesse identificar e expor à luz do dia a fantasmagoria. Agora, por que diabos um tipo como Adorno continuou a falar em filosofia são outros quinhentos para mais tarde, se houver chance. Habermas pelo menos se compreende, pois as crises do capitalismo tardio são encaminhadas nos quadros de uma argumentação pública sem conteúdos objetivos previamente dados, daí carecermos de uma teoria geral da racionalidade comunicativa. Acharia mais eficiente deixá-la a cargo dos juristas e outros bacharéis da modernidade.

ICC - Anote aí: você continua me devendo o Adorno, mas vamos fazer uma pausa para um gole d’água, já que não dá pra beber em serviço, e depois você retoma pelo Sartre. Falta a explicação: por que o Sartre, nomeado neste último capítulo da finada filosofia?

PA - Recordo que o Sartre acabou sendo mencionado de passagem devido ao seu plaidoyer em favor dos intelectuais. Daí o problema: o que viria fazer um intelectual no meio de professores de filosofia? A propósito, lembro que nossos frankfurtianos dos anos 30, muito embora rejei- tassem a ficção sociológica de Mannheim sobre a intelligentsia flutuando livremente sem amarras por entre as classes sociais, não estiveram muito longe de uma construção semelhante: Adorno costumava dizer que na idade do capitalismo monopolista o intelectual, sendo não obstante antiburguês, era na verdade o último remanescente burguês dos primeiros tempos liberais. A filosofia sobrevivente com a qual ele nunca deixou de flertar seria da mesma ordem? Se houver tempo, voltaremos a mais este modelo, igualmente duvidoso e imprestável (para os propósitos da cultura filosófica profissionalmente produtiva, como eram os nossos, uspianos). O Sartre tampouco, um modelo igualmente inviável. E além do mais, fomos exatamente colonizados pela filosofia universitária francesa (a primeira metade kantiana), com a qual ele rompeu. Pois o Sartre só poderia ter dito o que disse - um intelectual é aquele que fala do que não lhe diz respeito - por ter sido justamente o principal protagonista de uma transformação tal da filosofia francesa que ela pôde finalmente, graças a enxertos e transfusões os mais variados e heteróclitos, da fenomenologia alemã ao romance americano moderno, passando pela experiência política decisiva da Resistência, entroncar na grande corrente do pensamento francês, de expressão literária dominante, hegemônico na vida pública pelo menos desde o século XVIII. Sartre era ele mesmo uma personalidade cultural impura, um gênero intelectual híbrido, reunindo pela primeira vez numa só pessoa os dois tipos sociais antagônicos estudados por Thibaudet na Terceira República, o herdeiro-escritor e o bolsista-professor, o primeiro com fumaças aristocráticas e correspondentes fantasias a respeito do talento artístico por dom hereditário, o segundo, humanista oficial, esforçado como qualquer formiga do reino 
animal do espírito, o domínio mesmo das especializações superlativas. Ao mesmo tempo em que, muito impressionado pelo caso Céline, trazia de volta para a construção prosaica a inefável inspiração alegada pelos escritores-herdeiros (Barrès à frente, inclusive do pelotão dos anti-dreyfusards), Sartre ia desepistemologizando a filosofia dos professores (nossos ancestrais), encarnada no grande manda-chuva neo-kantiano, Léon Brunschvicg.

Pensando no nosso esquema acerca das duas vigas mestras entrelaçadas (por Hegel) da filosofia moderna, que sucumbiu mal alcançado o apogeu, já vou lembrando que Sartre também tinha na cabeça o Hegel da Fenomenologia do espírito, recentemente reinventado pela imaginação sem limites de um Kojève. Assim sendo, Sartre e seus companheiros de entreguerras estavam convencidos de que a filosofia, se quisesse voltar a interessar a todos (por exemplo, a um honnête homme de velha cepa), deveria abandonar o caminho inócuo da reflexão transcendental especializada nela mesma e retomar a via da experiência do mundo e suas variantes - política, estética, social, etc. - de sorte que, sobre o teorema comum das significações enterradas no chão bruto da experiência, literatura e filosofia poderiam se reencontrar - no caso, na figura do centauro sartriano.

Essa a mescla que em princípio autorizaria a circulação universal de Sartre (autorizado por alguma filosofia primeira? Com o tempo teria retransformado o Ser e o Nada num conjunto de teoremas transcendentais à maneira de Heidegger?) e sobretudo o seu direito irresponsável de falar, sem ser chamado é claro, fora de sua especialidade civil. Por isso foi considerado à direita e à esquerda um novo Voltaire. Enfim, um intelectual público, como alguns americanos preferem se exprimir hoje em dia, para melhor sublinhar o naufrágio da vida intelectual profissionalizada no brejo dos campi.

A direita viu muito bem naquele homem sem profissão - na verdade, ex-professor de ginásio como Alain - uma espécie de agente estimulador do ressentimento social, que ela considera subproduto natural do capitalismo e, portanto, a ser conservado em estado amorfo e residual. Quanto à esquerda, acho melhor já ir direto ao que pensava contra ele a nova esquerda pós-68 no momento da ruptura com o tipo intelectual levado por Sartre ao seu fastígio. Por contraste, poderemos saber algo mais a respeito, sobretudo quando seu contendor é um Foucault, o qual afetava nos anos 70 o maior desapreço pelo esforço literário da escrita (em se tratando de um francês, aí tem coisa, é claro) enquanto marca consagradora do intelectual: estava é claro aproveitando para desancar a turma da Tel Quel, com a qual aliás sempre esteve de bem nos anos 60, de vanguardismo estruturalista a todo vapor, acertar o Derrida (não estava falando por acaso em "escritura"), Barthes e Cia. Mas o grande alvo era mesmo Sartre, no qual via o intelectual-universal por oposição ao intelectual específico, um novo agente gauchista, curiosamente muito respeitador das competências profissionais. Tudo se passa como se Foucault estivesse dizendo o seguinte: Sartre no fundo é um herdeiro da tradição iluminista - aliás um segredo de Polichinelo -, e ainda por cima se julga um funcionário da humanidade (não aprendeu nada com o espírito de Natal demonstrado por Husserl à beira do abismo); seria verdade, caso fosse alemão e filósofo de estrita observância, mas sendo francês é sobretudo homem de letras; e nestas condições, que remontam ao que ele mesmo chamava de "negatividade" a propósito dos escritores-filósofos do século XVIII, é de esquerda porque escreve, e é intelectual 
porque é dreyfusard, e escreve bem por estar a serviço da verdade e da justiça, por isso é universal, e como tal é a consciência de todos (ou quem sabe a má consciência da sociedade, como a exercia um moralista do século XVII).

Em tempo e entre parênteses, só para reatar com o nosso esqueminha de antes: o que poderia ser para um existencialista alegar que escrevia em nome do universal, mais exatamente interpelando a humanidade na sua liberdade? E liberdade escorada na ausência de fundamento da contingência. Sendo existencialista, estava condenado a verificar diariamente a justeza descritiva da sociologia weberiana acerca da formalização crescente das relações sociais induzida pelo cálculo econômico de meios e fins. Já abordamos essa divisão do trabalho entre decisão existencial abstrata (embora a fraseologia da época batesse na tecla do "concreto") e inércia de coisa do famigerado em-si, entregue à afiguração dos juízos redutíveis a enunciados protocolares. Sartre também estava convencido de que não era mais possível morrer como um mujique de Tolstoi, saciado de viver por uma vida plena de sentido. Sabia que não era mais possível sem ridículo aconselhar ninguém, muito menos "narrar", tanto é que a fenomenologia, e Malraux, só lhe permitiam “descrever”: é que, na sua língua, o céu inteligível das ideias estava vazio, sendo liberdade e sentido matéria conjunta de invenção por definição injustificável. Na nossa língua de há pouco: razão objetiva, por motivo ignorado, era algo como uma enteléquia que desaparecera sem deixar rastros. O que complicava ainda mais a vida de quem cogitava de uma radical transformação da filosofia. A outra metade nossa conhecida, a experiência na sua totalidade à qual o novo filósofo podia atribuir um sentido desde que não falasse em verdade nem prometesse em consequência "teoria", era exatamente a mesma admitida pela consciência filosófica profissional a título de suplemento estético-metafísico da alma. (Nosso caso, de que já lhes falei, caso de alguns, é claro, com dupla personalidade - epistemologia no horário comercial, existencialismo after hours.) Mas Sartre tinha outras cartas na manga, e nem todas filosóficas.

Voltemos à implicância de Foucault, obviamente interessado em ficar com a vaga. Sendo inimaginável intelectual francês que não escreva e que não seja de esquerda (de esquerda "sublime", é claro, auto excluído de qualquer espécie de "representação", da estética à inserção social, salvo o empenho compreensível na própria carreira; por contraponto, o reformismo cabe aos representantes locais da "bela" sociedade à alemã, Habermas en tête), Foucault dá um jeito de associar a universalidade inerente ao figurino literário em questão à tradição do movimento socialista, já que ambos interpelam (para continuar a falar como Sartre) a humanidade no seu conjunto, de sorte que o intelectual-escritor, na forma da consciência clara e distinta, vem a ser igualmente central e universal, e isto na mesma medida em que também é, na forma obscura e coletiva da consciência de classe, o proletariado. Como crítica francamente desfavorável, não poderia haver maior elogio.

Há mais ainda, agora no capítulo dos acertos involuntários. Pensando em Voltaire, o patrono dos intelectuais que se imaginam universais, Foucault acha que esse tipo que está nos interessando discutir agora (sabe-se lá por que, vocês me diriam caso lhes fosse perguntado) deriva de uma figura histórica bem particular, o jurista, quer dizer, o homem da lei, o homem da justiça, que opõe a universalidade da lei justa ao abuso do poder e da riqueza, maneira engenhosa de reconduzir o socialista de há pouco 
ao coração da ilusão ilustrada. Vejamos o curto-circuito mais de perto. Sartre não diria que não, até se felicitaria: se o privilégio político do intelectual-escritor se funda na universalidade da lei justa e na centralidade produtiva dos esbulhados, deixa então de ser um privilégio. E se o nosso amigo Sartre estivesse àquela altura (primeira metade dos anos 70: já tinha lançado os três primeiros e derradeiros volumes do seu Flaubert) com o seu Marx na ponta da língua, poderia quem sabe torcer o argumento na boa direção, mesmo sabendo que o próprio Marx nunca morrera de amores pela gente letrada: o que eu chamei de "negatividade" no meu ensaio de 47 sobre o significado do ato de escrever, pensando sobretudo na grande chance histórica dos autores do nosso setecentos, Mannheim diria que flutuando livremente entre aristocratas cínicos e burgueses arrivistas, pode ser rebatizado com o nome de "crítica", que é universal por ser imanente, e com isso estou querendo dizer que o modelo jurídico da intromissão intelectual de tipo voltairiano atendia a uma exigência intrínseca da própria consciência social do momento, configurada pelo novo mundo do trabalho em gestação, de sorte que o abuso denunciado já pelo simples fato de escrever para um público em princípio universal era medido por um metro objetivo estabelecido pela própria realidade que assim se expunha à crítica por não cumprir o que ela mesma prometera. Podemos dizer então que, naquele limiar, a consciência generalista do intelectual-letrado se manifestava justamente (com perdão do trocadilho) no momento de pedir contas ao poder e à riqueza porque o fazia em nome da universalidade do mesmo direito no qual ambos se apoiavam em busca da mesma legitimidade. E mais: essa arena ainda se tornará mais visível no período seguinte, se nos lembrarmos de que a crítica socialista ao esbulho de que era vítima o trabalhador assalariado da parte do proprietário dos meios de produção, ou seja, que tal crítica não era extrinsecamente moralista como podia parecer aos espíritos filantrópicos, porém era, sim, uma crítica imanente na exata medida (nos dois sentidos da palavra: estou me lembrando do tempo em que a minha geração começou a ler a Fenomenologia do Espírito, e mais exatamente do trecho da Introdução em que o Hegel mostra que a consciência, por ser o seu próprio conceito, carrega consigo o metro-padrão com que tomará a sua própria medida, criticando-se sem descontinuar, é verdade que com muita dó, remorso e piedade, embora desconfie que no fim da história tudo lhe será restituído em dobro), na exata medida, dizíamos, em que tornava a pedir contas à alegada troca de equivalentes no processo de compra e venda da força de trabalho e a pedir contas nos próprios termos dos donos da vida de então, exatamente o mesmo direito natural racional dos tempos de Voltaire (aqui da plateia já podemos observar a Razão dos idealistas alemães entrando em cena), sobre cujo pano de fundo saltava então aos olhos intrinsecamente normativos da inteligência que compara a injustiça flagrante de tamanha desigualdade, fenômeno que por sua vez a Crítica da Economia Política poderia chamar, agora "cientificamente", de exploração. Assim, meu caro Foucault, ficaria mais fácil reconhecer muito menos o direito do que o dever do intelectual em meter o bedelho onde não é chamado. Basta pensar cruzando as fronteiras estabelecidas para que esta contradição básica se reapresente.

Se o Foucault realmente soubesse do que estava falando, em vez de ser mero sintoma, não deixaria barato, invocando a seu favor o fato de estar se inclinando diante de circunstâncias que convidavam à revisão de muitas 
certezas de esquerda: vivemos atualmente o desaparecimento do Grande Escritor e não digo isto pelo simples prazer de desbancar um símbolo nacional, ocorre que os nostálgicos do escritor-intelectual-universal que aspiram beatamente por uma filosofia-visão de mundo foram atropelados pelo carro da modernização. Dito de outro modo, Sartre foi no mínimo imprudente ao atrelar tão bem o destino do intelectual-escritor à centralidade da classe operária. Por isso, não por acaso, seus advogados (da causa do intelectual-universal-escritor-socialista) evocam nas entrelinhas a teoria do valor: e se esta tiver ido para o brejo, colapso camuflado desde os tempos do compromisso keynesiano, quando a intervenção do Estado, regulando as disfunções do mercado, tornou ainda mais cínica a consciência burguesa ilustrada, dispensada pelo poder público de voltar a se comprometer ideologicamente com a aparência da livre troca de equivalentes dos bons tempos da ordem liberal-competitiva, e, sem esse alicerce, onde o pé de apoio da crítica imanente que define a vida intelectual de cujo passamento estamos tratando? Maior será a queda quando a sociedade do trabalho encolher, e não faltam indícios neste fim de década pós-68, e um deles, quem sabe, não será a proliferação desse gauchismo ocupacional a que devemos o surgimento do intelectual-específico, perito profissional, com mandato recebido da subversão, mas dentro das fronteiras da sua especialidade.

Esta ficção não me parece inverossímil, e se assim é, não se pode deixar de reconhecer na sua inegável consistência sociológica os primeiros passos da fragmentação fetichista de hoje, responsável pela miragem de que nada totaliza mais. E, no entanto, não custa lembrar que estávamos falando de um modelo de filosofia transformada, cristalizado no imediato pós-guerra francês, modelo igualmente perempto, como diria o Bento, vistas as coisas em seu retrospecto, e pensando sempre nas ambições filosóficas de um não tão jovem assim franco-uspiano preparando-se para exercer seu métier porém carecido dos meios dissertativos adequados (e, logo depois, também das convicções).

ICC - Desisto! E comunico aos navegantes que, já que foi revogado na prática o decreto anterior relativo à proibição de mudança brusca de assunto e outras desconversas, vou também cortar o fio e adiantar o relógio nuns 25 anos - se estiver certa imaginando que a novela "drama da consciência filosófica profissional brasileira" estava no seguinte pé: em 1970 o então jovem professor aqui presente se encontrava em Paris encarregado de redigir e defender uma tese sobre Hegel mas não só ainda não sabia que não tinha na mão nem a faca nem o queijo, como tampouco sabia o que vinha a ser em tal circunstância faca e queijo, definidos ambos nos termos mesmos do seu objeto de tese, a saber, conceito e totalidade. Va bene cosí, professor?

\section{PA - Beníssimo.}

ICC - Então, como a novela continua, ninguém pode negar, ocorreu-me fazer, não uma pergunta, mas uma pequena reportagem, a propósito da querela Foucault-Sartre, adaptada ao drama em cartaz: saber se o filósofo profissional vem a ser um intelectual universal ou específico, quem sabe se universalmente específico ou especificamente universal, podendo ou não ser chamado a filosofar sobre Deus e sua época, o que literalmente Hegel foi o último a fazer. Continuo no caminho certo, professor? 
PA - Se eu soubesse qual, diria que sim...

ICC - Muito que bem. A matéria da minha reportagem não tem nada de especial, mas repõe o que estamos discutindo. Não faz muito tempo, foi em setembro do ano da graça de 1995, acompanhei uma conversa entre o nosso entrevistado de hoje e dois jovens doutorandos em filosofia, escalados pela Teoria e Debate, revista do Partido dos Trabalhadores, para fazer uma entrevista com o nosso memorando aqui. Era coisa de variar o quadro intelectual opinativo, recolhendo impressões de um não-orgânico, sem com isso insinuar que um filósofo infeliz na sua pele pertença ao reino mineral...

\section{PA - Nunca se sabe!}

ICC - Muito que bem. Encerrada a inevitável vida-e-obra de praxe, o Paulo arrematou com os seguintes considerandos: vocês hão de convir que quem cuida de filosofia não é a pessoa mais indicada para abordar os assuntos do interesse dos leitores de uma revista como Teoria e Debate. É claro que fora do expediente procuro acompanhar como posso o "curso do mundo", como se denominava antigamente o real objeto da última filosofia, a de Hegel, como todos sabem (aliás, nós agora sabemos até demais, inclusive as rubricas do nosso amigo, já que ninguém é de ferro); assim, com escassos recursos próprios e muita ajuda de amigos que sabem das coisas, procuro exercer meu hoje em dia modestíssimo métier de cidadão. Ora, cidadão por cidadão, é sempre preferível ouvir o especialista, ou então o militante esclarecido - nunca é demais lembrar o samba de Adoniran Barbosa, Torresmo à milanesa, o caso daqueles operários da construção civil, sentados na calçada depois do almoço, a "falar sobre isso e aquilo, coisa que nós não entende nada”.

Nem preciso dizer que os prolegômenos não caíram bem. O puxão de orelha veio no ato: se é assim que você pensa, podemos encerrar a entrevista por aqui mesmo. Mas, sem querer, você nos deu o mote para relançar a conversa. Não negue, enquanto desconversava, você devia estar pensando mais ou menos assim: esses moços, meio ofuscados com o atual sucesso de mídia da filosofia, vieram me entrevistar com a maior naturalidade sobre os assuntos do dia e os tópicos clássicos de sempre. Mas se eles soubessem o que eu sei sobre a cozinha da profissão, que não impõe mais respeito nem a um cacique político nordestino, ou melhor, sobretudo a um patriarca que conhece os seus bacharéis, não cometeriam tal desatino. Por isso é minha obrigação de professor adverti-los em tempo, lembrando: primeiro, que a filosofia é uma especialidade universitária entre outras; segundo, que é um modo de ganhar a vida tão prosaico quanto outro qualquer, o que desafina com o estilo elevado que o gênero herdou do seu ilustre passado pré-capitalista; terceiro, que é raríssimo ver um profissional da área levar uma vida arejada pela reflexão (como lembrou certa vez uma alma escarninha), muito embora, em conformidade com a vida congregada que é a nossa, frequentes vezes (como costuma falar um dos nossos próceres) nos reunamos em colóquio para responder à pergunta “o que nos faz pensar?"; quarto, que as exceções, para variar, confirmam a regra, como é o caso dos melhores, meus professores é claro, que só despertam para a vida do espírito quando param de falar em serviço, e que este último costuma se vingar nos aposentados, fraudados na sua justa expectativa de repouso - como a alma em estado de ciência de Aristóteles - por inquieta- 
ções metafísicas fora de hora. E assim por diante. Se adivinhamos o seu pensamento, você vai nos desculpar mas se enganou redondamente sobre as nossas intenções. Convenhamos: saímos à procura de um dos últimos marxistas - pelo menos consta que assim seja - e encontramos um senhor conformado com a divisão social do trabalho intelectual. Francamente! Se fosse para discutir programas de estabilização, com ou sem âncora cambial, ou coisa que o valha, saberíamos a quem procurar. Não é disso que se trata. Ou melhor, esperávamos de sua parte, imaginando que alguém que passou pelo marxismo e nele continua como pode, só admite ser chamado de "filósofo" por acidente biográfico ou apelação da mídia e instituições de fomento na falta de melhor rótulo, que por complacência seus confrades acabariam aceitando, pois esperávamos de sua parte uma contribuição para furar essa compartimentação que curiosamente lhe inspira tantos escrúpulos. Quanto à mídia, também seria o caso de um outro sonoro francamente! Dela não faz parte uma publicação de um partido socialista (oops!?), mesmo que queira. Ou nos enganamos? Além do mais, não somos jornalistas, não que haja mal nisto, mas em todo caso não estamos atrás de uma boa "matéria", mesmo de esquerda, sob medida para determinada estratégia editorial, etc. Também não entramos bem (sic) na categoria de ex-aluno entrevistando velho professor. Nada contra, mas não ignoramos que este vínculo clássico pesa muito nas redações. Mas não ajudaria a vender jornal se o velho professor prestes a se tornar mercadoria não se apresentasse revestido de um atrativo suplementar, sem falar é claro na incontrolável boa vontade de servir à causa do aprimoramento cultural da opinião pública. Desnecessário frisar que nem de longe estamos insinuando que seja o seu caso em qualquer des- ses itens. Mas embora a ideia sem dúvida meio bizarra de entrevistá-lo não nos tenha ocorrido por isso, o crescente sucesso de mídia da filosofia é um fato a pedir explicação, mesmo sendo a tal filosofia apenas "traço" na conjuntura, aliás como muita coisa decorativa, embora de primeira plana.

\section{PA - Obrigado por me entregar.}

ICC - Disponha. Notem que ele não me corrigiu uma vírgula até agora. Aceito o puxão de orelha, declarou o professor que em absoluto não se conformava com o que eles estavam dizendo que ele estava conformado. Observou, a seguir, que embora devesse, de fato, não por bravata mas por fé de ofício materialista, ser a última pessoa a respeitar a divisão das competências, universitárias ou não, ninguém podia em sã consciência ignorar que a separação delas é parte significativa da engrenagem das alienações modernas e que portanto superá-las não é apenas uma questão de vontade ou método apropriado...

PA - Ao lhe agradecer a inconfidência, não estava pensando na comediazinha ideológica a que você assistiu. É que agora me vejo na infeliz contingência de justificar aqueles requebros preliminares, a saber: vocês bateram na porta errada; quem sou eu; desde quando professor de filosofia fala do que interessa; perguntem a quem entende; vivemos numa cultura de especialistas; patati, patatá. E não acho modo de fazê-lo sem entregar o ouro (na minha imaginação, claro) dessa conversalhada toda.

MEC - Pois então não faça. Mantenha o suspense, mesmo que a gente não saiba exatamente em torno do quê. 
PA - E recomeçar os dengues? Nessa não caio mais! De resto, já plantei a notícia na inauguração desta conversa de agora. Vocês se lembram? Alguma coisa de vexatório sempre haverá no intelectual cinquentão tapando os buracos elementares de formação, mas a triste figura só vinha ao caso porque se tratava de introduzir logo de saída um termo de comparação obrigatório, uma geração notável que tivera a chance histórica de aprender a pensar - e a escrever - refletindo sobre o Brasil, mas com recursos tais que acarretavam a imediata desprovincianização do seu raio de ação cultural. Pois não era outro o rumo abortado da minha desconversa inicial com os dois rapazes, os quais achavam a coisa mais natural do mundo pedir a um "filósofo" que comentasse a atualidade nacional, dando de barato, é claro, que eles não estavam minimamente interessados em questões de método e outras generalidades. Correndo o risco de me fazer de difícil, talvez um pouco além da conta, achei que devia salientar com alguma ênfase e vários negaceios as pedras num caminho que noutros tempos fora natural, como no tempo de Hegel - por onde imaginava principiar a minha historinha que vocês agora já devem estar cansadas de saber.

Havia mais segundas intenções, no entanto. Por um lado, precisava deixar claro que mesmo em nosso fundinho de quintal ainda não nos refizemos de um choque de primeira grandeza, até porque dele não tínhamos notícia muito precisa, a saber, o fim da filosofia clássica alemã, em virtude do qual se produziria uma verdadeira dissociação da sensibilidade filosófica, sem querer dizer com isso que, na época em que Schiller concebeu sua Educação estética da humanidade, a linguagem dos filósofos evoluía de tal modo no topo dos sentidos que pensar para eles era um ato tão fisicamente concreto quanto sentir o perfume de uma flor ou de acompanhar um encadeamento musical. (Não me ocorreria brincar assim com a famigerada dissociação eliotiana da sensibilidade se não estivesse como estou agora rodeado de literatura por todos os lados mas, pensando bem, tem coisa naquela projeção retrospectiva inteiramente ideológica sobre os sucessos literários do passado inglês às vésperas da Revolução Puritana: para falar como a Iná, alguém precisaria avisar o Sr. T.S.Eliot de que o choque de modernização burguesa dissocia mesmo, que aliás as imaginárias sociedades ditas orgânicas morrem é disso, que em outros termos mais precisos preferimos chamar de alienação; ao que eu acrescentaria que era este mesmo o problema de Schiller, a funesta e moderníssima dissociação de sensibilidade e entendimento, que o classicismo alemão, filosofia incluída, não teria sido a bela construção ideológica que de fato foi se não achasse que só a imaginação - um outro nome para a Razão de que vínhamos falando até agora - poderia soldar aquela falha característica dos Tempos Modernos, invertendo o raciocínio como mandava a boa lógica da defasagem alemã.) Mas voltemos à nossa dissociação muito menos heroica, embora pertencente à mesmíssima família de efeitos: como disse, achava que os dois jovens filósofos (e quis a ironia inerente às situações gauches de entrevista que um estivesse preparando tese sobre Habermas, outro sobre Adorno) bem que poderiam igualmente sentir na própria pele os pruridos do veterano, fazer por indução ou compadrio a experiência levemente inibidora de que as sobras da antiga cultura filosófica tenham se tornado definitivamente impermeáveis ao que em tempos melhores seria considerado o seu objeto em pessoa, a não menos famigerada Totalidade, igualmente entranhada por sua vez até mesmo numa notícia de jornal, à qual deveria empres- 
tar profundidade tornando o conteúdo de experiência, ali presente e do qual ela é o conceito, narrável - não fosse a alienação sem brecha que nos tira o fôlego. Essa a matéria vertente, no caso em pauta, exatamente jornalística. Se falasse como "filósofo", rigorosamente nada a dizer - sem rigor, então, nem se fala; se falasse como um leitor obsessivo de jornais, falaria pelos cotovelos porém como um amador, nada garantindo que um profissional não reproduzisse também a mesma aparência socialmente necessária de sempre. Um bloqueio que só se fura pensando, se for permitida a demasia.

Ora, se meus "duelos y quebrantos" estivessem bem amarrados poderia começar a ficar claro que quem passou a vida comentando textos de filosofia decididamente não aprendera a pensar, drama da consciência profissional que vocês também já estão carecas de saber. Daí o termo de comparação obrigatório, naquele início de conversa necessariamente implícito, pelo qual na de agora por via das dúvidas resolvi começar deixando-o, entretanto na moita apenas enunciado, como era do meu dever socrático: esconder o leite sempre. Na verdade, a geração que tivera os meios de aprender a pensar refletindo sobre o Brasil estava ali muito bem representada in absentia na pessoa do entrevistado do último número da mesma revista, o nosso amigo Roberto Schwarz. Era questão de dar nome aos bois e completar o raciocínio: só o talento não explicava por que ele dera conta do recado. Havia, portanto, em cena não só um método de ataque na forma de um estilo pessoal, mas um domínio e o seu correspondente ponto de vista, um domínio justamente de coisas que interessa a todos pensar - em particular, todos os leitores de uma revista não sectária de um partido socialista -, e mais, perfeitamente incompatível com a referida vida intelectual compartimentada, que a ser assim não é de fato nenhuma. Se naquela hora tivesse rebatizado a esfera em questão de "experiência brasileira”, precisaria acrescentar, ato contínuo, que nem por ser brasileira a dita experiência carecia de profundidade, a ser construída é claro a partir do momento em que se atinar que desde os primórdios da nacionalidade ela foi bifronte como era da natureza mesma da nossa formação colonial, já no plano mental levada com o redobrado esforço exigido pela dupla fidelidade vivida por todo intelectual brasileiro, coisa portanto a um tempo nacional e sobredeterminada pela instância mundial sem cuja sanção não pode se reproduzir. Mas, dito isso, como deixar de reconhecer, nessa inesperada embora familiar conjunção de particularidade e universalidade, o processo em sua inteireza que a velha filosofia ainda em vida costumava chamar de Totalidade? Também precisaria acrescentar que não alimentássemos em consequência nenhuma ilusão a respeito do abismo entreaberto entre filosofia, profissional ou não, (mera cláusula protocolar, pois não existe outra), e vida nacional (que jamais se limitou ao especificamente nacional, volto a insistir, apoiado sobretudo na evidência de que somos comparatistas natos sob todos os aspectos), ambas sucedâneos das duas metades apartadas por Kant e que Hegel a seu modo rejuntou no espaço de uma geração. Não é só que a brecha seja intransponivel para talentos de tamanho fluminense, os dois termos desse bisonho vis-à-vis são rigorosamente incompatíveis, sequer vivem no mesmo mundo. Então seria este o fio vermelho percorrendo a novela "drama da consciência filosófica profissional no Brasil": encontrar uma via de passagem que permitisse o acesso organizado ao velho assunto da filosofia que parece se reapresentar sob outra forma, mas cuidando metodicamente de ir dei- 
xando pelo caminho o ponto de partida inassimilável, a cultura filosófica herdada. E se é esse o foco, cedo ou tarde nossa conversa passará por aqui de volta.

MEC - Tudo bem. Se for assim, é só esperar. Mas já que a Iná escancarou a porteira, também posso contribuir com outra reportagem. E pra vocês não dizerem que estou fugindo do assunto, vou avisando que ainda se trata daquela opinião de Sartre - "só é intelectual quem justamente se mete no que não lhe diz respeito" - para ver se a transformação da filosofia francesa ainda poderia nos alcançar com meio século de atraso. É a propósito da barreira ao impulso opinativo mais consistente representado pela divisão social do trabalho intelectual. Então vamos lá: não é que deu na imprensa, se não me engano em julho (de 95), com toda a cara de plantada, a notícia de que a pedido de Lula um Comitê do Partido dos Trabalhadores chamou um grupo de intelectuais simpatizantes, porém não militantes para, junto com alguns do partido, também especialmente convocados, trocar figurinhas sobre o quadro nacional depois da vitória do FHC. Até aí nada de mais. $\mathrm{O}$ inusitado da história é que numa reunião anterior, depois de uma rodada de desabafos oposicionistas, cujo teor dá para imaginar à vista do bloco inamovível do establishment, consta que o mesmo Roberto Schwarz, há pouco citado, quando falou, lembrou calmamente por a $+\mathrm{b}$ que a presidência Fernando Henrique se distinguia da dos seus antecessores imediatos - pela ordem: fisiológico, aventureiro, folclórico - por uma espécie de respeitável consistência sociológica, decorrência de uma bem calculada sintonia com o novo rumo do capitalismo mundial, cuja incidência local alterara os parâmetros nacionais da luta de classes. $\mathrm{O}$ surpreendente é que tal opinião tenha surpreendido os presentes, sendo alguns dirigentes.
ICC - A mim não surpreende coisíssima nenhuma. Partido Social-Democrata é isso aí. Ainda por cima encalacrado, muito além da conta, por falta de social-democracia à vista, coisa do passado até mesmo na terra natal desse traidor "compromisso histórico". O que surpreende é que ainda não tenham aprendido nada, nem pretendem, já que estarão na parada de novo nas próximas eleições. Só um exemplo. No ano passado, em plena campanha, saiu na Folha um longo artigo do Professor José Luiz Fiori, cientista político sem nenhum vínculo com o PT, o que, pelo que sei, incomoda muito a alta tucanagem, que fica privada do argumento número um: "vocês petistas". Muito que bem. Esse artigo ficou famoso por ter introduzido à sua revelia um desses motes prediletos da mídia, o tal de Consenso de Washington, no entanto arquiconhecido nos meios especializados. Pois bem, a linha de argumentação oposicionista era puxada para o plano internacional do capitalismo mundializado e os seus respectivos diretórios, político e econômico, ambos articulados na forma de um oligopólio mundial (para falar como François Chesnais, que designa pelo termo não uma forma de mercado, mas um espaço de concorrência feroz e, ao mesmo tempo, de interligação entre os grandes grupos econômicos da Tríade), exigindo por definição adaptação incondicional, inclusive às barreiras, a rigor intransponíveis, a estratégias privadas das firmas multinacionais e aos diktats dos mercados financeiros globalizados. O plano de estabilização então desfechado era o carro-chefe desse "ajuste", aliás atrasado, mas em tempo de se tornar o grande eleitor da campanha, é claro que um timing programado para essa feliz coincidência. Tudo isso para lembrar que o artigo do José Luiz Fiori vinha desagradavelmente dizer à moçada na esquerda que o epicentro daquela eleição (e das 
futuras) já não estava mais (nem voltaria) ao varejo da política nacional. O nosso bravo Partido dos Trabalhadores fez ouvidos de mercador, e não era para menos, pois não era bem notícia que se dê a candidatos a gestor, social, é claro, de uma normalidade capitalista que nunca foi tão remota como nos dias que correm.

CR - Agora é que desandou de vez. Alguém quer ter a bondade de me explicar o que isso tem a ver com o livro aqui do nosso autor? Ou já mandamos passear sem aviso prévio a ideia de um posfácio conversado, porém razoavelmente econômico de prosa? Se papel fosse mato, não teria nada a opor, pois jogar conversa fora é comigo mesmo. Acho até muito instrutivos esses altos papos de vocês. Parece seminário de sociólogo!

MEC - Tudo a ver, minha filha, você está esquecendo a Totalidade? O que não tem nada a ver é com o que eu estava dizendo, não era esse o meu ponto, e a Iná sabia perfeitamente disso...

ICC - Foi só um aparte para lembrar que o buraco fica muиuito mais embaixo... ou muitos pontos acima...

PA - Ora, Maria Elisa, também não precisa enxovalhar assim a pobre Totalidade. Que ela se vinga, e é sempre maligna. Com o livro, obviamente não tem nada a ver, mas isso depõe contra o próprio sem desacreditar o Conceito. Mas tudo a ver com as idas e vindas do autor tateante, do qual fez gato e sapato. Poderia começar lembrando que ele, o livro indigitado, deriva de uma percepção confusa do vaivém entre raciocinação filosófica e vida nacional num determinado momento histórico, mais exatamente um caso de consciência nacional infeliz a meu ver exemplar, o alemão. Ora, como estava dizendo, se fosse para começar agora um retrospecto do equívoco na base do livro, a maneira pela qual no Brasil dos anos 70 se concebiam as várias transições nacionais para o mundo moderno do capital, o termo de comparação atual obrigatório seria exatamente a situação da Novíssima Dependência - para falar como o José Luiz Fiori e seus amigos do Instituto de Economia Industrial da UFRJ - que a Iná estava trazendo para o centro da conversa. Entre o primeiro artigo e o lançamento temerário deste livro largado no meio do caminho, transcorreram vinte anos em que a problemática referência nacional que lhe servia de horizonte mudou de lugar e de natureza, sem falar que eu sabia pouco quando comecei a tratar muito enviesadamente do assunto, de sorte que dar alguma notícia da origem e destino dos textos, meio desajeitados, reunidos no volume a perigo e tomar posição sobre a atualidade cultural da desintegração do espaço econômico e político nacional, provocada pela mundialização do capital, são uma só e mesma coisa. Mas vou esperar mais algumas voltas da conversa. A esta altura, ir direto ao ponto mais embrulha do que desfia.

MEC - Acho bom mesmo, pois eu não tinha a menor intenção de abandonar a minha reportagem sobre matéria nem tão palpitante assim: filósofo ou similar chamado a falar a torto e a direito. Mas não se trata, nesta matéria jornalística, de filósofo e sim de crítico literário, relembro, só para aumentar a confusão. Retomando: decidiu-se convocar outra reunião, encarregando-se o mesmíssimo Professor Roberto Schwarz de abrir o encontro expondo por extenso sua opinião (imagino a ciumeira que o encargo despertou, mas deixa pra lá), o que ele fez, tendo pre- 
parado para a ocasião um mini-paper muito caprichado, como sempre. Continuo vendo com total simpatia a iniciativa do PT, mas em se tratando de um crítico literário, das duas uma: ou o Partido vai mal, se não estiver pior, no caso de uma encenação para inglês ver, ou a crítica literária no Brasil vai muito bem.

ICC - Por que não as duas?

MEC - Ah, Iná, qual é a sua? Estamos no mesmo barco literário e sabemos muito bem que o Roberto é uma exceção e por quê.

PA - Se não for indiscrição, gostaria muito de ouvi-las a respeito, pois também tenho a minha versão, da qual depende aliás larga fatia das minhas ruminações comparativas acerca das vidas paralelas, a filosófica e a literária.

MEC - Logo chega a sua vez, dá um tempo agora. Enquanto isso, você vai encarando o contraexemplo do ângulo atualmente em discussão - o das competências universitárias desrespeitadas competentemente - e no caso por um representante da minha corporação e não da sua. Aproveito para lembrar que naquela reunião também estava presente um jovem professor de filosofia, mas não foi possível verificar se interveio nos debates nem apurar o que eventualmente teria dito. O outro contraexemplo constante da minha matéria também deu nos jornais, mas ele se passa agora no campo situacionista. Parece que a Presidência da República teria criado oficialmente um grupo de estudos com a incumbência de, abre aspas, descortinar horizontes para o Brasil no próximo século. A inspiração pode até ser os grupos juscelinistas de trabalho, mas a coisa outra vez está mais para seminário, só que agora a pequena legião de intelectuais recrutada procede toda ela muito razoavelmente das ciências sociais (embora muita gente do ramo desconfie que sociologia e ciência política já não tenham mais objeto, mas deixa pra lá). Até aí também nada de mais, considerando que os estrategistas do novo establishment achavam que a taxa de credibilidade do atual plano de estabilização exigia igualmente uma variável intelectual, ou melhor, "acadêmica", como eles dizem agora no american accent - para mim, acadêmico ainda é estudante parnasiano de direito ou componente de escola de samba, com todo o respeito -, imaginando que um analista de risco de um fundo de investimento internacional se sentirá um pouquinho mais confiante nos papéis brasileiros ao saber que o governante local, sendo ele mesmo do ramo, prudentemente se cercou de inteligências bem aparelhadas, como outrora o mexicano Porfírio Diaz, rodeado por sus científicos. Pois bem, o mais interessante é que, completando a simetria entre as duas providências nos campos antagônicos (será mesmo?), está presente no segundo, se li direito os jornais, e trazendo novamente à baila o nosso assuntinho do momento, as barreiras em que se enreda a cultura dos especialistas, o seu amigo Giannotti, e como sempre, sem maiores inibições quanto ao arco opinativo da competência de um filósofo, haja vista a desenvoltura, sublinhada há pouco por você mesmo, com que se intrometeu na política de alianças do seu Presidente, seu dele, é claro. Como todo mundo viu (ou leu), os caciques envolvidos estrilaram, o maioral deles chegou ao insulto e outros lances mais da tradicional baixaria das classes altas brasileiras, só que tudo, curiosamente, em nome da divisão de trabalho... 
ICC - Aliás, nunca é demais lembrar que o mesmo princípio também vigorava nos partidos comunistas, daqui e de fora. Althusser, por exemplo, podia filosofar à vontade (Garaudy e comparsas estavam em baixa fazia tempo), até porque era levado a sério na École Normale (cala-te, boca!), desde que não se metesse a filosofar sobre a política do Partido, coisa que por sinal ele acabou fazendo lá pelo fim da vida. Por onde se vê como Sartre era uma figura à parte. Mas daí a pensar num similar brasileiro...

PA - Fim das reportagens paralelas? Para não dizer que eu também não estou fazendo jornalismo... A propósito: nos anos heroicos de instalação da cultura letrada universitária em São Paulo, muita gente boa temia que João Cruz Costa, de tanta impotência especulativa, de tanto implicar com o que ele chamava depreciativamente intelectual puro, de tanto sobrepor as questões terra-a-terra de um país em construção aos grandes problemas filosóficos sem tempo e lugar, não resvalasse para uma espécie de jornalismo disfarçado de filosofia.

ICC - Pois eu vou dar um pouco mais de corda, não sei para quem. Já que está em pauta o Sartre advogando a causa do intelectual generalista por ter aprontado uma verdadeira transformação da filosofia francesa, sem no entanto nem de longe poder reativar a tradição clássica pré-48, e também considerando que compreendemos que uma filosofia da existência como a dele não poderia sem desastre tomar o lugar da filosofia universitária com a qual ele em boa hora rompeu e que viria a ser a matriz da cultura filosófica tão desejada pelos paulistas - resumo bem, professor? -, tudo isso considerado, não posso resistir à tentação de voltar à temível colher de pau do Giannotti, para ficarmos num dos objetos da sua predileção. Consta que o General de Gaulle teria dito certa vez ao seu Chefe de Polícia, um tanto impaciente com a autoridade pública volta e meia desacatada pelo enfant terrible do momento, que não se pode mandar prender Voltaire. Acontece que o nosso filósofo número 1 é amigo do De Gaulle de plantão. Você nos dirá que o problema não está no primeiro mas na carreira do segundo e mais, não fosse este último um intelectual, e pior ainda, um dos nossos (do seu time, bem entendido) até anteontem, e não estaríamos (você e os marxistas ocidentais brasileiros) nessa encrenca ideológica toda, recusando com uma das mãos o que julgam inevitável com a outra. Não custa insistir de novo que eu estou fora, desde meus verdes anos, desta coreografia. Mas isto agora não vem ao caso.

Voltando. Esqueça por um momento a tal comissão de intelectuais encarregada de "descortinar horizontes" (nada contra a lembrança da mesma, até porque lances pândegos são sempre bem-vindos: não custa perguntar, mas que "horizontes"? Vocês sabem que eu não sou kurtziana de carteirinha, mas nem por isso a minha pressão deixa de subir quando ouço a palavra "catastrofista" a propósito do teórico alemão, pelo simples motivo de que ele não fez nenhum prognóstico e sim o contrário, pois a catástrofe real já aconteceu e bem lá para trás: então, que "horizonte" a descortinar? Mas deixa prá lá). O caso, aqui, é que não podemos deixar passar em branco um crítico literário expondo em reunião do PT o novo estado das coisas. Vamos tomar o problema por outro ângulo. Que problema? O mesmo entregue agora há pouco: o tópico filosofia, trabalho intelectual compartimentado, via de acesso à experiência brasileira. Repito: ficou claro que a ascendência de Sartre, peculiaridades francesas à 
parte, pois estamos falando do paraíso dos intelectuais, como dizia com inegável despeito o anglófilo Raymond Aron, não teria sido possível, muito embora não fosse uma condição suficiente, sem uma concomitante transformação da filosofia, que deixaria de ser uma espécie de tribunal epistemológico de última instância (mesmo com a transformação sartriana teria mesmo deixado de aspirar a algum posto de observação e juízo o mais elevado possível?), para concorrer em pé de igualdade com a literatura na interpretação da experiência, mas com que instrumentos se daria essa mágica, fica difícil de imaginar. Ora, em contrapartida, a não menos inegável ascendência do seu ex-professor Giannotti não se deve a nenhuma transformação da filosofia, no sentido indicado, muito pelo contrário, mas a um, proclamado aos quatro ventos, aprofundamento do seu viés estritamente técnico-profissional. Paradoxo? Por enquanto me limito a puxar um fio desse disparate, como você diria, com a intenção amigável de levar um pouco de água para o seu moinho. Num depoimento bem conhecido (deu na Folha em outubro de 94 e deve estar saindo agora em livro) sobre o mitológico (para não falar em outras deduções amalucadas que foram inspiradas pelos desdobramentos do dito cujo) Seminário Marx da Rua Maria Antonia, o Roberto Schwarz faz mais ou menos a seguinte observação sobre as intervenções lógico-metodológicas do Giannotti, às quais, segundo o próprio faz questão de sublinhar, a intensidade intelectual do Seminário devia muito: a vontade de dar um grande passo à frente estava no ar, e o sentimento de que isso enfim seria possível naquele momento; muita vontade também de enterrar de vez a vulgata comunista e de se contrapor aos manuais americanos de metodologia empírico-funcional; vontade, en- fim, de escapar à trivialidade subindo vários degraus na vida teórica. Sendo assim, estavam todos de acordo que o estudo de Marx deveria ter extensões filosóficas - e o Giannotti estava ali para convencê-los disso, no que deve ter tido sucesso pois a sua tão decantada tirania metodológica causava a maior excitação. Por quê? Ora, o nosso amigo Roberto sugere que em boa parte por superstição, dando a entender que havia uma certa atmosfera de acatamento, alimentada pela ala dos cientistas sociais ali presentes, pois devia ser voz corrente na Faculdade que cabia ao filósofo uma espécie de missão fiscalizadora (a-do-rei o termo!), da qual sempre se esperava o esclarecimento decisivo que permitiria a todos passar para o referido plano superior de intelecção máxima. Deixando de lado os não menos reveladores relatos do Professor Fernando Novais sobre alguns cômicos entremezes filosóficos, daria para continuar?

PA - E como! Também sou de opinião de que não é pequeno paradoxo uma explicação bem-sucedida do Capital monitorada pela luz atrapalhada da falsa consciência, filosófica no caso, e ainda por cima conforme o entendimento a respeito da própria tradição marxista. Você me dirá - ou, por outra, não você, é claro - que na acepção da pior vertente dessa tradição, e que na geração dos marxistas ditos ocidentais a coisa mudou de figura, com a filosofia de volta ao primeiro plano, recolhida piedosamente, junto com a arte moderna, na vala comum da alienação. Pois continuo achando que isso depõe contra eles, me antecipando à sua réplica. Reconsideremos então o caso dos frankfurtianos, de longe os mais interessantes dessa denominação “ocidental”. 
CR - Pela música, vem fantasma. Não sei por que me ocorreu essa expressão, que conheço de algum lugar, mas não me lembro qual.

ICC - É de uma chanchada do Oscarito. Ponto pra você.

CR - É mesmo! Eu queria dar este aviso aos navegantes: digressão à vista. Mas antes que se consume o ato, gostaria, não de lavrar protesto, pois admito que estou me divertindo bastante com esses meandros, todos no melhor estilo mogiana - como acabei de aprender -, mas só para ver se estou entendendo bem o que se passa. Só uma impressão, de resto variável. Às vezes me dá a impressão de conversa de sociólogo - dou esse exemplo não por implicância ou qualquer conhecimento especial, mas porque passa pela minha mesa de editora muito livro dessa raça, ou melhor, passava, pois eles têm rareado ultimamente - conversa de sociólogo, eu dizia, do tipo condições sociais da explicação sociológica da função do sociólogo nas sociedades em transição, não me lembro bem transição para onde. Às vezes me parece coisa de alemão - outro tipo de livro com o qual também tenho que lidar. Volta e meia eles entram num papo arrevesado de meta-isso, meta-aquilo, metacrítica disso, metateoria daquilo, ou então a autocompreensão metodológica que um autor tem de si mesmo na sua autoconsciência teórica. Se eu fosse uma alemã de verdade, diria que caí no meio de uma conversa, claro que não muito profunda, metafilosófica, mais especificamente uma metacrítica do conhecimento infelizmente prejudicada em sua pureza metodológica pelo excesso, sem dúvida pitoresco, de coloração anedótica.

MEC - Um a zero, Christine.
PA - Se não houver mais manifestações de apreço e louvor, gostaria de me explicar.

ICC - Pela música vem fantasma, como lembrou a Christine.

PA - Exatamente. A graça de pensar em brasileiro é que as coisas acabam fazendo sistema, com perdão do galicismo. Ainda mais quando saem dos trilhos, como parece estar ocorrendo agora. O caso é o seguinte: no Brasil tudo se passa como se a filosofia da filosofia precedesse a própria filosofia. Infelizmente, o achado não é meu, mas do Bento (Prado de Almeida Ferraz Jr.), que acertou no milhar sem, no entanto, dar a mínima ao feito. Nem podia: naquele tempo, sobretudo naquele tempo, o assunto filosofia no Brasil era menos que lixo, por razões que fatalmente uma hora deverei abordar por extenso. O fato é que em 1968, ano em que o Bento, por encomenda de uma revista italiana, escreveu um ensaio sobre o problema da filosofia no Brasil, ensaio no qual se encontra a observação da qual sou invejoso, tal problema era unanimemente (entenda-se: uspianamente) considerado um falso problema. Primeiro, porque a filosofia no Brasil (entendamos novamente: em São Paulo, nos anos 60) ia muito bem obrigado, entendendo-se por filosofia boas teses sobre assunto filosoficamente consagrado como tal na bibliografia; segundo, porque filosofia nacional felizmente não existia, ou pelo menos tal veleidade não existia mais.

Dito isso, ou melhor, simplesmente pressupondo sem muita perda de tempo, o nosso autor passava ao comentário de dois equívocos exemplares. Um, do isebiano Álvaro Vieira Pinto, e outro do uspiano simpático, porém fora de esquadro, suspeito de enturmar com o atraso, o João 
Cruz Costa de que já falamos. Esta última, a anomalia que nos interessa agora mais de perto, uma sobrevivência do antigo regime intelectual visto que o ensaísmo fora de época do Cruz Costa era largamente tributário da finada ideologia do caráter nacional, para usar o título do livro famoso do Dante Moreira Leite. Pois bem, o jovem Bento Prado (às vésperas de completar 31 anos no dia fatídico da invasão soviética da hoje também extinta Tchecoslováquia) demonstrava com toda razão, por $a+b$, que a mais que duvidosa e já ultrapassada ideia de caráter nacional ainda conseguia causar um derradeiro estrago quando transposta para o domínio mais exigente e depurado da filosofia, cuja autonomia e universalidade comprometia sem perdão por se tratar de uma ideia psicologista (expressão de uma "alma" nacional ou "espírito de um povo") e historicista (identidade de um sujeito que evoluía em continuidade ao longo da história nacional), sem falar que consciência, história e cia., a mais recente e avançada filosofia francesa riscara do mapa ideológico. Não que fizessem falta do jeito que vinham sendo concebidas até caírem em desgraça. Mas passemos.

No caso de Cruz Costa em particular, como o tal caráter se distinguia pelo primado da razão pragmática, herdada da alma portuguesa, felizmente mais amiga do pão-pão, queijo-queijo do que dos altos voos característicos do tenebroso barbarismo dos heráclitos alemães, no dizer de uma sumidade lusitana que o Bento gostava muito de citar, cedo ou tarde acabaria encontrando a fórmula filosófica que melhor se ajustasse à sua índole gostosamente materialista, que Cruz Costa estimava fosse a mais vulgar possível, tal horror lhe inspirava o veio condoreiro nacional, que ainda por cima acintosamente contrariava sua tese quanto à nossa natural aversão pelo estilo monumental.
Ao Bento interessava muito menos (para não dizer nada) o teor específico da tese acerca do nosso suposto caráter original do que o estilo de indagação à qual tal fantasma obrigava Cruz Costa, condenado a vasculhar o passado e o presente de nossas preocupações filosóficas de segunda classe à procura de indícios precursores de um reencontro filosófico com a nossa realidade mais profunda - ou melhor, rasa. Pois era essa busca no passado dos germes de uma filosofia que no futuro ainda haveríamos de ter, caso atinássemos com o modo de pensar que enfim nos exprimia, busca comovedora na sua insensatez da filosofia que estaria por vir, pois era nessa procura de filosofia marcada por uma espécie de desencontro recorrente que o Bento achava por sua vez que se poderia identificar alguma coisa como uma experiência muito particular da filosofia no Brasil. Mas justamente uma experiência tanto mais enfática por se destacar contra o fundo de uma carência que, por sua vez, não seria sentida como tal se não o fosse por contraste, repentinamente visível e evidente porque o nosso filósofo uspiano achou que era do seu dever mostrar ao leitor europeu que nós também tínhamos o nosso Foucault na pessoa de Antonio Candido - este último, quando leu o artigo, congratulando-se com o autor, observou que Michel ia ficar muito contente.

Inútil lembrar que o ainda mais jovem aluno de Bento Prado assinava embaixo e divulgava. Mas talvez também ajude lembrar que o dito aluno, relendo o artigo quatorze anos depois, e tirando o Foucault da jogada, reteve a comparação entre a formação da literatura brasileira, que se completou quando Machado entrou em cena, e a formação da filosofia no Brasil, que a rigor nunca se completou (nem poderia, se me expliquei bem no que ficou dito lá atrás), ainda que o desejo dos paulistas de ter uma filosofia tenha 
se realizado plenamente dos anos 60 em diante: pois até hoje vou vivendo dessa comparação entre as duas formações, lembrança original do meu primeiro professor de filosofia, Bento Prado Jr, que não sabia muito bem o que fazer com ela, nem tinha como, àquela altura.

Como disse, endossava com vibrante entusiasmo patriótico-epistemológico aquela aproximação sem pé nem cabeça (aliás, de uns tempos para cá, refeita como grande descoberta desconstrucionista pelos concretos e congêneres, só que rigorosamente de ponta-cabeça, perdendo a antiga graça do orgulho uspiano em alta). Então era isso aí: o leitor italiano poderia verificar que nem tudo estava perdido na cultura teórica brasileira; havia honrosas exceções ao baixo nível historicista e psicologista a que nos condenavam nossos complexos nacionais, sendo a mais excepcional delas a concepção da literatura como um Sistema que se poderia encontrar no livro de Antonio Candido. De um lado, simples manifestações literárias desgarradas, diacronia em estado bruto; do outro, porém, não um sistema qualquer mas um verdadeiro sistema diacrítico de obras articulado num espaço de oposições pertinentes. Sendo assim, há literatura quando ler um autor, graças à existência de um tal Sistema, significa interpretar en creux (outra expressão dileta do nosso amigo) o espaço em branco que o separa dos demais, de sorte que nenhuma alma nacional se exprime nesse Sistema. Pelo contrário, é nele (no qual se reconhece sem esforço a linguagem devolvida à sua condição de sujeito, mitema de que se nutria a ideologia literária francesa da época) que os indivíduos reinterpretam a sua alma, com aspas, é claro. Nada de parecido do lado da filosofia, cujo registro de nascimento ainda não foi lavrado - na boa observação dele, à qual o seu ex-aluno também tratou de fazer justiça vinte anos mais tarde (tudo é vagaroso na modesta consciência técnica da escola de São Paulo, cumprindo a profecia de Mário de Andrade). Até o momento nada além de "manifestações filosóficas" avulsas - algumas até que boas (Bento falava em "notáveis") mas prudentemente não especificava os agraciados pela hipérbole -, de resto literalmente manifestações das correntes europeias em voga, de sorte que resenhá-las, mesmo as "notáveis", deixaria o especialista estrangeiro na mesma, pouco lhe adiantando saber que aqui também se fazia (é a palavra) fenomenologia, positivismo, existencialismo, marxismo, etc. - sendo que o etc. e as más companhias comprometiam pela raiz o dito marxismo, ocidental por certo, seja dito de passagem.

Em suma, mesmo engessando Antonio Candido com as talas estruturalistas, da sincronia $\mathrm{x}$ diacronia, Bento viu o essencial (repito: com o qual ninguém naquele momento, sobretudo entre os mais velhos, saberia o que fazer, pois a hora era deânimo construtivo acelerado a fim de pôr em funcionamento a vida filosófica local), a saber, que a nossa curiosidade filosófica não se organizava no tempo próprio de uma tradição, que os trabalhos desencontrados que ela por vezes inspirava não se articulavam nos moldes do correspondente sistema literário identificado por Antonio Candido, verificando em consequência que era sempre de fora que lhes vinha a coesão. Machado de Assis falaria em influxo externo (ainda) predominante: mas custaria tempo, e outro tanto de mudança social refletida, para atinar com as coordenadas ajustadas àquele registro precursor - tempo e o trabalho de Roberto Schwarz, bem entendido.

Pois foi então do ângulo deficitário dessa formação filosófica que sequer principiara (mal sabia o Bento que ela estava prestes a se completar, porém correndo por uma 
outra pista que não dava para imaginar), que o nosso herói reparou que no seu país a coruja de Minerva costuma levantar voo ao amanhecer (é claro: depois de uma noite na taverna, consumida na prelibação dos prolegômenos da filosofia que um dia virá; enfim, com o futuro a menos, passada em branco em conversas como a de hoje), que vivemos uma temporalidade invertida, na qual a reflexão curiosamente precede a percepção. É daí que vem, Christine, nosso vezo metafilosófico. Somos a pátria dos prolegômenos a toda e qualquer filosofia que queira um dia se instalar por aqui.

ICC - Desculpe, gente, mas eu me vejo na obrigação de avisar que o professor agora está fazendo uma gracinha com o título de um livro do Kant, os Prolegômenos, que por extenso chama-se Prolegômenos a toda filosofia que no futuro queira se apresentar como ciência, uma introdução didática à Crítica da Razão Pura, só que, por sinal, escrita depois dela, em vista das bem fundadas reclamações sobre a dificuldade para se ler o tratado propriamente dito... É só para complicar mais um pouquinho. E prometo que não faço mais.

PA - Posso continuar? Obrigado. Eu ia dizendo que esta é a terra dos prefácios a uma filosofia futura. Há mais, no entanto neste capítulo dos sucedâneos, das preliminares que se arrastam antes do jogo principal. Como você acabou de comprovar pela presente conversa sempre na antevéspera de alguma coisa que nunca acontece, não por acaso passando em revista modelos filosóficos que não nos servem (ainda que a impropriedade derive de uma inadequação histórica do velho gênero aos novos tempos inaugurados pela degringolada da cultura burguesa), a tal procura reflexiva que nos define ainda persiste. E se isto é fato, quer dizer que a compulsão de filosofar sobre a filosofia em vez de filosofar pour de bon não se extinguiu com o passamento da finada ideologia do caráter nacional, que a ser assim devia estar repercutindo alguma encrenca real recorrente.

Reconsideremos o caso Cruz Costa. Salvo a piada do pragmatismo português - possivelmente sua única piada mal calibrada -, coisa difícil de acreditar à vista da longevidade de outros antigos impérios coloniais, sem falar na incultura fradesco-forense amortalhando o reino cadaveroso da metrópole, salvo portanto o tropeço que o levou a tomar veleidade e decadência por espírito empreendedor de largo fôlego, no que concernia a ex-colônia, Cruz Costa simplesmente achou que devia aplicar às nossas futuras circunvoluções filosóficas a mesma cláusula utilitária que vinha balizando nossa evolução mental: fosse prosa, verso ou ensaio, não escrever ou pensar nada que de algum modo desservisse o empenho de consolidação da nacionalidade. De certo modo o pequeno realismo sentimental, que amarrou nossas letras durante o longo período que Antonio Candido denominou literatura de incorporação, continuava bem-vindo no caso das letras filosóficas de que carecíamos, mas sem exagero.

Fosse como fosse, a filosofia que nos convinha de algum modo, ou melhor, do mesmo modo que a literatura e mais tarde o ensaio de interpretação sociológica, deveria contribuir para a cristalização da consciência nacional, que só é consciência, diga-se de passagem, em favor de Cruz Costa, se o for dos contrastes e contradições locais, de preferência não acomodáveis. Ocorre, como já sabemos, que não havia mais nenhum equivalente filosófico disponível, em condições de se desincumbir de uma tarefa histórica 
análoga. Pensar, enfim, filosoficamente o Brasil, pois afinal era isso o que em última instância queria Cruz Costa - e se não fosse mais possível, melhor mandar às favas de uma vez a tal de filosofia. Assim, nos dois registros em que Cruz Costa perseguia uma filosofia que não fosse simples mania, ou fantasia sem proveito, como gostava de dizer, procurava em vão: no âmbito local, porque era da natureza de tal demanda que ela nunca pudesse ser satisfeita, até porque o horizonte ideológico muito raso diminuía em muito as chances de reflexão com recursos próprios; na esfera da tradição erudita de arribação, porque a filosofia profissional era imprestável por definição, ela mesma resultado de uma queda histórica, como vimos. É preciso, portanto, reconhecer que, mesmo trocando as bolas, Cruz Costa sabia muito bem o que vinha e o que não vinha ao caso. Tanto era assim que namorava firme as grandes filosofias populares do tempo, o marxismo e o positivismo, pois algo lhe dizia que naquelas grandes sínteses, tão abrangentes quanto desiguais e rudimentares, devia circular ainda um arremedo daquela fusão entre os dois conceitos de filosofia, o "técnico" e o histórico-mundial, empreendida por Hegel ao arrematar o ciclo histórico da filosofia como forma.

Já que estou respondendo ao justo desabafo da Christine, abro um parêntese para uma falsa, porém quem sabe instrutiva analogia com a situação alemã (no fundo, o tal livro do qual ainda não falamos e nem sei se chegaremos a falar, não é mais do que isso). Como a Christine lembrou muito a propósito, é lá que se encontra a terra natal das grandes manobras diversionistas meta-isso, meta-aquilo, onde enfim tudo é pretexto para um longo Discurso do Método preliminar. É só dar uma olhada na correspondência Goethe-Schiller. Muito fácil, é claro, para quem vai muito depois na cola do Lukács, o primeiro a saber que se aprende estudando os impasses dos clássicos alemães: pois ali praticamente não existe esboço de obra projetada, e nem sempre realizada, que não se apresente precedido da respectiva teoria preparatória, geralmente levada ao limite da especulação formal, o que importa em dizer que boa parte da Teoria Estética foi por assim dizer escrita à distância do seu objeto, que aliás só era encontrado na sua inteireza moderna em Paris ou Londres. Um caso portanto de prolegômenos hipertrofiados por razões de tenuidade nacional, ou ainda, abusando um pouco mais da comparação, cultura teórica superlativa (nunca foi o nosso caso) e compensatória (nisto, sim) por falha de formação (a queixa a respeito era uma constante de Herder a Goethe, sempre de olho no modelo francês, onde a massa de espírito acumulada permitia a qualquer autor, com a mão bem assentada por experiência herdada, sentar-se à sua mesa de trabalho e escrever sem precisar teorizar até que o assunto nascesse como que por fricção entre conceitos à procura de matéria; queixa análoga num Sílvio Romero, à vista da falta de seriação em nossas ideias, só que agora seu ideal de vida intelectual orgânica era projetado nos alemães). E o que valia para a literatura e sua índole ruminativa exasperada, valia ainda com maior força obviamente para a filosofia, cuja autonomia enquanto discurso regido por critérios próprios de validação não por acaso tinha a mesma índole do processo aparentado de autonomização da arte: o que é a Crítica kantiana (como já foi observado noutra direção) senão um monumental Discurso do Método, de novo um aquecimento interminável com vistas a uma partida sempre adiada sine die?

Para variar o exemplo, é só reparar na mudança de nome introduzida enfaticamente por Fichte: em vez da 
amadora Filosofia, a profissional Doutrina-da-Ciência, ou Epistemologia Fundamental, na justíssima tradução de Rubens Rodrigues Torres Filho. Repito: é só notar que, com o intuito científico-profissional assumido às claras e programaticamente, vem junto o evidente redobramento reflexivo próprio de uma filosofia da filosofia. Impossível metafilosofia mais acabada.

Fechemos o parêntese alemão e voltemos ao Brasil isto é, fiquemos na mesma, se consegui me explicar a respeito da invenção histórica da filosofia profissional stricto sensu. O funcionamento organizado da cultura filosófica em nosso meio, na forma de cursos superiores bem planejados à europeia, ao contrário do esperado - de semelhantes iniciativas de atualização em sociedades retardatárias -, não erradicou a antiga compulsão metafilosófica, antes deu-lhe um novo e inesperado alento. Acabamos de ver porquê, em parte pelo menos: por ser inerente à autonomização do raciocínio filosófico, na origem de sua especialização profissional, o momento reflexivo em que a razão dessubstancializada se apalpa, a ver o que ainda pode legitimamente fazer num mundo indiferente aos seus decretos. Uma coisa não vai sem a outra. Acresce que o transplante do novo ramo da cultura moderna, de certo modo, exponenciou-lhe a tendência ao ensimesmamento. E isto ao menos por duas razões: em primeiro lugar porque era preciso dar o primeiro combate ao amadorismo local e este se apresentava de preferência na forma da mania doutrinária em estado bruto, do tipo adesão incondicional à letra do último livro lido, mas também, como vimos, na forma popular das grandes cosmovisões filosofantes, de redenção nacional, panaceias sociológico-metafísicas que por seu turno ignoravam sua condição polêmica de resíduo dos sistemas filosóficos anteriores à queda de 48 , para rotinizar de uma vez a nossa periodização - a profilaxia modernizante exigia então uma espécie de recuo antidoutrinário, um método suspensivo que resfriasse os conteúdos e fizesse a tônica recair na dimensão formal da arquitetônica dos sistemas; em segundo lugar, reforçando por sua vez o formalismo dessa propedêutica, a própria circunstância do transplante, uma técnica intelectual importada que não pode carregar consigo a matéria social que lhe definia o sentido, deixava à mostra de corpo inteiro uma cultura filosófica, suspensa no ar, as raízes bem visíveis por falta de solo apropriado ao enxerto entretanto inevitável. Uma tal constelação de descompassos e revelações nos devolvia assim com novo ímpeto à terra estéril da filosofia ao quadrado. A menos que se demonstrasse o vazio da ilusão complementar, as fantasias a respeito de um conhecimento filosófico específico. E num certo momento (uspiano, inútil lembrar, como sempre) esta reviravolta esteve prestes a se completar, a elevação altamente estilizada de nosso eterno recomeço de principiantes à procura da filosofia que melhor lhe convenha à condição de natureza mesma da filosofia moderna, de preferência de vanguarda. Essa cristalização metafilosófica estava em curso quando se viu posta em concorrência com a decisão de nossos maiorais de sair a campo e filosofar para valer mas com que roupa? Como você vê, Christine, fugir do assunto é conosco mesmo, sem falar no charme de imprimir a essa desconversa um selo metafísico made in Germany, porém de fatura abstrata inconfundivelmente parisiense.

MEC - Um a um.

ICC - Informou o nosso placar eletrônico. 
MEC - Mas acho que eu saquei! Então esse foi o capítulo chove-não-molha da novela "drama da consciência filosófica profissional em São Paulo”. Certo?

CR - Se entendi bem a aula particular, em função do que veio antes, daria para completar a deixa em favor desses tais profissionais em crise de consciência (será mesmo? eles me parecem tão sossegados, tocando o serviço com tanta competência que até parecem alemães...) relembrando que a moderna chuva filosófica não foi mesmo feita para molhar coisa nenhuma? (Garanti imperméable: deve ser por isso que vende bem...)

ICC - É isso aí. Mas antes que venha mais metafilosofia explícita, volto atrás no meu decreto e sugiro fecharmos de novo a porteira (eu ia dizer torneira...). Só para vocês terem ideia, está anotado no meu caderninho que o professor ainda está devendo os seguintes tópicos: $1^{\circ}$ ) já não me lembro mais por quê, a certa altura veio à baila a Mimesis do Auerbach, do qual segundo o Bento Prado (não é, Maria Elisa?), Vossa Excelência, em algum momento (de elevada modéstia, por certo, bem ao estilo da mescla auerbachiana) cogitou de realizar algo como um equivalente filosófico; $2^{\circ}$ ) esclarecer por que a um crítico literário será permitido, em circunstâncias especiais, se não for mesmo do seu dever, transpor a barreira dos saberes confinados e comportar-se como um verdadeiro intelectual, e não a um filósofo, que em princípio visa ao todo (como vocês sabem, minha dúvida é apenas pro forma), embora a superstição acadêmica ainda sustente exatamente o contrário; $3^{\circ}$ ) a propósito da participação destacada do filósofo José Arthur Giannotti no Seminário do Capital, o que o teria levado, você, não o Giannotti que nunca se interessou pe- los frankfurtianos, aos quais sempre teve na conta de moralistas choramingas e passadistas (que eu sei), além de achar que eles são muito fracos em lógica (pode?), o que, como todo mundo sabe no Instituto de Matemática e Estatística, é condição indispensável para se compreender em profundidade o mundo contemporâneo; o que o teria levado, enfim, há coisa de meia hora atrás (no mínimo) a achar que viria ao caso uma comparação com os frankfurtianos dos anos 30? Suponho que você estava pensando no tal de "materialismo interdisciplinar", que para Brecht, é bom lembrar, era coisa séria, e que os nossos amigos Ricardo Musse e Marcos Nobre volta e meia tiram do bolso do colete, ora contra, ora a favor, ainda não entendi bem. O que eu sei é que o Lukács de História e consciência de classe achava que totalidade e especialização científica num mundo racionalizado pelo Capital não podiam andar juntas, enfim, que partido leninista não é instituto de pesquisa e vice-versa, com ou sem pitadas de consciência luxemburguista espontânea ou fortes simpatias sindicais. Registrados os itens para posterior comentário (os outros deixo para depois), proponho que retomemos o fio de nosso enredo, a saber, o mal-estar do nosso memorando na filosofia, desconforto que pelo menos tem a vantagem inestimável de dar um rumo a esta conversa. Em que pé estava o nosso romancezinho local de educação?

MEC - Nos anos de viagem, se não me engano.

PA - Pelo menos atravessei o Atlântico. Como, no entanto, viajei da filial para a matriz, fiquei na mesma. Também neste sentido meu Erziehungsroman seria um pastiche. Já informei - a pedido, advirto - que entre fins de 69 e meados de 73 andei por Paris fazendo em casa uma tese sobre 
Hegel. Em casa, porque tive a sorte grande de ser dispensado de qualquer obrigação escolar por meu orientador, Jean-Toussaint Desanti, que, não sei por que, foi com a minha cara. Mas em casa também porque, para todos os efeitos, continuava na Rua Maria Antonia, que aliás também se transferira para lá nas pessoas de Bento Prado, Roberto Schwarz, e mais tarde Ruy Fausto, para ficar no capítulo dos professores, com os quais segui conversando em primeira mão, como era do meu gosto de aluno. De sorte que, naqueles anos de viagem, Paris foi sobretudo cenário. Além do mais, como nascera para a filosofia completamente afrancesado, podia me dar ao luxo de esnobar o star system em pleno apogeu. Por assim dizer blasé por antiguidade. Salvo duas ou três excursões ao curso de Foucault no Collège de France, nem mesmo por curiosidade etnográfica (hoje me arrependo) fui espiar em plena função Lacan, Barthes, Althusser, Derrida, Deleuze e Cia. Só mais tarde cuidei de transformar a alergia sincera em argumento. No momento, bastava a aversão, devida menos ao marxismo uspiano ainda mal digerido do que ao bom-mocismo de uma criatura da velha filosofia universitária francesa, como sempre muito mal impressionada com o que lhe parecia mera fumisterie, uma outra rodada "modernista" à imagem e semelhança da temporada "existencialista" anterior.

Também continuava em casa porque minha principal referência era o recém-publicado A paciência do conceito de Gérard Lebrun, último maître-à-penser da filosofia franco-uspiana. Acho que o verdadeiro divórcio começou ali (era muito mais fácil para um paulista naquele momento resistir à enganação desconstrucionista, ou às machines-désirantes, por exemplo), tal o esforço de catar razões que permitissem explicar de outro modo achados que a meu ver (ainda confuso) seu autor anulava tão logo os descobria. Nas minhas contas, só vim a dar com elas, salvo engano, é claro, uns oito anos depois.

MEC - Nunca vi ninguém cronometrar com tanta minúcia a marcha lenta do próprio raciocínio.

PA - As tartarugas costumam ser escrupulosas. Idiossincrasias à parte, acho até que os lerdos em países normalmente acelerados como o Brasil devem ser estudados como um indicador sociológico a mais de nossas mazelas. Quem sabe não se resume a isso o possível interesse do meu triste caso? Pois então: atravessara o oceano para ficar na mesma. A começar pela Tese, uma enorme lição de casa. Daí o disparate: uma tese sobre Hegel feita em Paris e não em Frankfurt, ou outra marca prestigiosa equivalente, escrita num francês engomado, muito encostado nas soluções sintáticas do Le Monde, segundo o figurino escolar da historiografia estrutural (em sua acepção mais elementar e indubitável), um olho em Kojève (contra), Hyppolite (mera bibliografia), Lebrun (ora contra, ora a favor), outro no anti-hegelianismo da Ideologia Francesa. Outro disparate: a tese era discretamente marxista, concebida dentro dos limites do mais estrito decoro acadêmico, quer dizer, era marxista na acepção uspiana do termo. Seu não tão jovem autor portanto nunca tinha lido História e consciência de classe, seus professores Giannotti e Ruy Fausto sim, mas já haviam arquivado aquela velharia. Os frankfurtianos, então, nem pensar (quando muito, da parte do Ruy, o voto piedoso, formulado numa aula em 67, de que um dia ainda haveríamos de ler os Três estudos de Adorno sobre Hegel, e quem sabe, entendê-lo); tampouco o new look do jovem Habermas (que, não sei por quê, 
já tinha fama de chato, mas paguei caro: no que respeita às relações entre trabalho e linguagem em Hegel precisei inventar a roda); quanto a Marcuse, li o que todo mundo lia em 68, mas achava, não sem razão, como uspiano aplicado, que o seu Hegel era inaproveitável, muito embora tenha sido ele o primeiro a levantar a lebre das "feridas do espírito que se curam sem deixar cicatriz", o que valeu a Lebrun uma bela dissertação de pós-graduação em 65. Mas em compensação, graças a Giannotti e Ruy Fausto, também era contra Althusser, cujos tabus teriam paralisado qualquer estudo sensato sobre Hegel. É fato que lá pelo meio do caminho comecei a ler aqueles clássicos do marxismo alemão de entreguerras, mas já não havia tempo para mais nada, sobretudo porque não saberia o que fazer com o pouco que entendia, quando muito renderam uma ou duas notas de rodapé bem desajeitadas.

ICC - Mas o que era então o "marxismo"? Por onde ele andava na sua tese? O gato comeu?

PA - O gato pelo menos era de bom tamanho. O Giannotti achou que eu exagerara na dose, que me saíra um Hegel marxizado demais da conta. A rigor, giannottizado, pois a centralidade do Trabalho assegurava, entre outras coisas a dimensão ontológica da Dialética, ao contrário da meramente epistemológica ou "discursiva" como queriam os raros franceses que ainda desancavam Hegel com um certo conhecimento de causa - uma não tão simples assim "façon de parler", segundo Lebrun, repito, autor do mais original e inventivo livro francês sobre Hegel, desde as maluquices de Kojève e a estreia de Jean Hyppolite. No fundo, eu simplesmente estendera ao conjunto do Sistema, textes à l'appui é claro, o que o jovem Marx dos
Manuscritos dissera sobre a Fenomenologia do Espírito, cujo motor residiria na transposição da noção de trabalho, recém inventada pela Economia Política, para a dimensão filosófica do Conceito, e sua consequente inversão positivadora, como gosta de dizer o jovem oswaldiano Vinícius Dantas. Marxismo também era o seguinte, na dita genealogia uspiana de que descendia: primado do ponto de vista lógico sobre o baixo nível "historicista" (dos gramscianos, por exemplo, ou do Lukács dos anos 20). Noutros termos, sem chegar a ser mais um interminável Discurso do Método (como diria anos depois Perry Anderson a propósito do marxismo ocidental), corria o risco de não chegar a ser nada ("cientificamente" respeitável, ou logicamente convincente, como diria mais tarde, noutra circunstância, o mesmo Giannotti) sem uma clarificação metodológica prévia, mesmo correndo o risco de encalhar em questões de método (onde Sartre se deu mal). Prevalecendo o tal ponto de vista lógico (instância fiscalizadora fantasmagórica que no entanto funcionou como mecanismo a serviço da apuração do nível, como lembrou Roberto Schwarz no depoimento há pouco citado sobre o Seminário Marx), não só a filosofia enquanto gênero ou forma escapava milagrosamente da crítica, mas com ela também saía ilesa a divisão social do trabalho intelectual e seu cortejo de alienações; neste mesmo passo ficava estabelecido que era nossa obrigação preparar o terreno sobre o qual repousavam os fundamentos do Capital remontando à corrente da tradição, Hegel em primeiro lugar por certo, e daí até Aristóteles - sendo todo mundo estudioso, completaríamos o álbum às vésperas da compulsória. Eu mesmo iniciei a redação da tese convencido de que se tratava de um exercício preliminar, considerando-me naturalmente escalado para em seguida colaborar na procura da chave do 
reino escavando na Ciência da Lógica. Chave e fechadura estavam obviamente trocadas, mas seria grave pecado historicista imaginar que figura assumiria a hipótese inversa. Logo explico como principiei a desconfiar que embarcara numa canoa furada. Desconfiava, e depois tinha certeza, mas nem de longe os meios para desembarcar. Quer dizer, para simplesmente perceber que o normal seria reler Hegel e a tradição filosófica pelo filtro do Capital e, uma vez postas as coisas em perspectiva no seu devido lugar, atinar com o nexo social que emprestava substância histórica às idas e vindas da Dialética hegeliana.

MEC - Quantos anos precisou desta vez o nosso veloz Aquiles para atravessar o Canal da Mancha?

PA - Uma década. Graças a um desvio. E como ele não é nem um pouco filosófico, sempre se poderá dizer que minhas providências são inócuas e inconclusivas. Em resumo: o autor estudado na tese era um precursor patenteado; o assunto, mesmo a contracorrente da hegemonia althusseriana do momento, constava do repertório marxista clássico; e, como promessa, reincidir no topos da fundamentação lógico-ontológica última da Dialética. Tudo enfim era marxista ocidental franco-uspiano. E por isso mesmo tudo era marxista, menos o "livro" enquanto tal, concepção e realização, para início de conversa - em suma, de marxismo mesmo, nem sombra.

ICC - Ainda que mal pergunte, de novo: e por onde andava esse tal marxismo dos seus sonhos?

PA - Sonhos uspianos, sempre. Na minha cabeça é que não. Na de outros, sim. Mas custei a descobrir.
MEC - Outro quarto de século? O professor deve confiar muito na longevidade...

PA - Pasmem, foi ali mesmo em Paris e bem antes de voltar para São Paulo.

MEC - E podemos saber como se deu tal milagre?

PA - Disparate, melhor dizendo.

MEC - A saber?

PA - Descobri o Brasil.

MEC - Aos trinta anos?????

PA - Perdão, aos vinte e oito.

MEC - Para quem espera chegar aos noventa, é uma bela estreia... Desconfio que, entre o achado temporão e dar com a forma apropriada de lidar com um objeto tão tardiamente identificado, não deve ter passado pouco tempo, para variar.

PA - Exatos treze anos, dos quais me permito subtrair os três consumidos pela tese. De novo uma década para entrar diretamente no assunto. Agora, quanto a assentar a mão, são outros quinhentos.

MEC - Unbelievable!!!!

CR-Dá licença de lembrar que na historinha grega Aquiles não alcança a tartaruga? 
PA - Agradeço de coração, mas estas coisas só acontecem em filosofia, no caso, matemática tomada ao pé da letra.

ICC - Vocês não estão abusando um pouco dos passes laterais? O nosso memorando não mexe profissionalmente com filosofia? Pois então. Admito que essa contabilidade miúda, um tantinho maníaca pro meu gosto, antes realça do que encobre a possível inépcia do autor nos seus verdes anos. Mesmo assim, ainda acho que deve ter pesado muito mais, agravando a dita falta de jeito, tão custosa e lentamente atenuada, a circunstância ingrata da especialização filosófica. Gente, não se pode honestamente atribuir à índole original de um indivíduo o que é puro efeito de relações sociais!

PA - Novamente, agradeço mais esta tentativa de salvamento. Posso me explicar? Como a Iná acabou de lembrar, circunstâncias atenuantes é que não faltam. Quem cuida de filosofia no Brasil, pelo menos segundo o figurino mais apertado da escola exigentíssima em que me formei, está praticamente condenado a se desinteressar, em termos profissionais sobretudo, pela realidade próxima do país. Já vou avisando que vou repisar coisas ditas noutras ocasiões, inclusive nesta conversa. Não me lembro mais, na hora de editar a gente abrevia ou joga fora. Creio que a propósito de Cruz Costa e toda aquela história do voo ao contrário do mocho filosófico brasileiro, como o pássaro Jujuy da zoologia fantástica borgiana, que voa de costas embora não padeça de despertar precoce como a nossa coruja metafilosófica.

Pois bem. Acontece que o desejo dos paulistas de ver a cultura filosófica instalada no Brasil funcionando segundo padrões civilizados de pertinência técnica nunca chegaria a se realizar, caso os pais fundadores e seus descendentes não tivessem tomado algumas providências drásticas, como por exemplo cortar relações com o passado amadorístico local. No que andavam certos, já que o objetivo era alcançar alguma coisa como uma consciência profissional máxima. De resto, fé de ofício ditada pela própria natureza do transplante em curso, os usos e costumes da filosofia universitária francesa. E estes exigiam, em nome da moderna autonomia do discurso filosófico, que se produzisse uma espécie de vácuo histórico em torno das obras, salvo as generalidades de praxe. Coisa fácil de obter e convencer entre nós, sobretudo em se tratando de um enxerto num meio cuja tenuidade tornava ainda mais improvável a continuidade social da vida filosófica do espírito. Era, portanto, natural que déssemos as costas ao ambiente acanhado em que evoluíam os diletantes, no geral vítimas das leituras da véspera, ocasião de conversões fulminantes. De nossa parte, na falta de mediações mais substantivas, oferecíamos pelo menos, Dona Maria Elisa, a marcha lenta, muito lenta, das aquisições metódicas restaria saber do quê, para além dos textos. Agravando o futuro desencontro, é preciso lembrar que os novos técnicos da inteligência filosófica eram de esquerda, na acepção radical-uspiana do termo, enquanto as "capacidades" filosofantes locais preteridas no geral eram de direita. E, como tal, patriotas. Nesta condição, a confiança nas letras filosóficas nacionais pretéritas era ponto de honra, além de penhor das grandes vocações em exercício no Largo São Francisco. Daí a desfeita ressentida com o marco zero alegado no campo adversário, onde a filosofia, como já sabemos, era coisa para o futuro e estava a caminho na sala de aula, hibernando nas bibliografias criteriosamente autorizadas. Confirmado o divórcio por evidente incom- 
patibilidade de gênios, ficava estabelecido que qualquer interesse filosófico pela marcha inexistente das ideias no Brasil era politicamente suspeito e, além do mais, epistemologicamente nulo. Sobre este ponto sem dúvida tínhamos razão, mas era uma razão mortal. Assim, das ideias barateadas ao país rebaixado, o passo parece lógico. Só que ao dar tal passo, como de fato demos, entrávamos na contramão da vida intelectual brasileira.

Não custa repetir, pois pode acontecer desta conversa chegar aos ouvidos de menores de trinta anos: desde os primórdios da nacionalidade, e isto se não recuarmos até o gosto arcádico pela sociabilidade intelectual construtiva, a nossa vida mental sempre girou em torno do esforço, a um tempo de ilustração e expressão, voltado para a desobstrução das vias de passagem da Colônia para a Nação. É bem verdade, relembro ainda, para o governo dos mais jovens, que este mesmo zelo civilizador de nossos próceres nunca se acanhou diante das alternativas mais obscurantistas, como a constelação sombria escravidão, latifúndio e monarquia, na hora solene da Independência. Repisando: ninguém pensava ou escrevia sem um voto de confiança na transformação da Colônia em Nação, de sorte que todos imaginavam que o país não avançaria desassistido de um tal progresso da consciência animada por esse empenho ideativo. Ora, a essa regra histórica de decoro intelectual nem mesmo a filosofia escaparia, sobretudo no período heroico de sua instalação em nosso país, admitindo-se que se tratava também de um esforço superlativo de aprimoramento cultural. Aqui, no entanto, a contracorrente em que sempre nos debatemos.

O mesmo ímpeto progressista que empurrava homens de letras e ideias para o enquadramento brasileiro dos seus assuntos nos arrastava na direção contrária. Numa palavra, para dentro dos textos, aliás remotíssimos, porém fora da vida nacional. E vice-versa: uma vez dentro da vida, como era do dever de cada um, afinal éramos todos radicais, era porque já estávamos fora do texto. Não havia hipótese (será que já não falamos disso?) de um sistema qualquer de vasos comunicantes nos restituir à cultura viva do país, errada, mas viva. Nem mesmo se cogitava disso. Até porque do lado mais desperto da consciência intelectual brasileira esperava-se de quem cuidasse profissionalmente de filosofia, além de cursos e monografias que nada ficassem devendo ao similar europeu, alguma contribuição original que permitisse ao espírito nacional pairar nas altas paragens dos grandes problemas universais. Acho que estou me repetindo, mas não importa, pois é preciso relembrar (sim, me lembro: a propósito do esforço descarrilado de João Cruz Costa de filosofar sobre o Brasil e caso isto não fosse possível, abandonar de vez a filosofia) uma outra razão explicativa desse desencontro entre filosofia e vida nacional, vida nacional atrofiada pela herança colonial recalcitrante. Pois são justamente essas sociedades mal-acabadas, de cultura reflexa e por isso mesmo deprimidas pelo confronto obrigatório com a inteireza europeia, que mais carecem de uma "imagem" que as revele (ou encubra de vez), reaprumando-lhes a consciência nacional infeliz de nascença. Não acedem elas portanto à consciência, nem cumpre o intelectual seu correspondente mandato, sem o apoio de uma "representação" qualquer, de preferência, como sabido, impregnada de cor local, seja ela poesia, prosa de ficção, memória historiográfica, relato de viagem, pintura de paisagem ou cena cotidiana, etc. - obsessão com a construção da imagem que melhor retrate o país e que ainda alcançará por exemplo o Cinema Novo ou, por definição, as modernas 
Ciências Sociais, que aliás não por acaso declinam quando a referida "imagem" nacional começa a se apagar. Aqui o nosso esqueminha.

Se não estou vendendo gato por lebre, já sabemos faz tempo (há horas, pelo menos) que a filosofia desde a reviravolta fatídica de 1848 deixou de ser "figurativa", e por isso mesmo, desde que se tornou “profissional”. Vejam então o curioso entrecruzamento. Não empreguei a expressão “figurativa" à toa. Ela consta do repertório lebruniano, em particular da já mencionada Paciência do conceito, mais ou menos na seguinte direção, no rumo do imbroglio que me interessa retratar agora. No livro anterior, sua grande tese (como se dizia antigamente no jargão acadêmico francês) sobre a Terceira Crítica de Kant, a Crítica do Juízo, Lebrun descrevera a seu modo o que estamos chamando de filosofia profissional: onde vemos o afunilamento irreversível da cultura de especialista, ele via na descoberta ou invenção da reflexão transcendental em separado o marco zero de uma emancipação (para empregar aliás a propósito uma palavra da qual ele não gosta nem um pouquinho), o nascimento moderno da filosofia aliviada do fardo da "representação", fenômeno que ele também compreendia muito originalmente como o princípio do "declínio da Teoria”, já que com a referida Crítica do Juízo não dava mais para não ver que Kant entronizara a Crítica no terreno oposto ao de uma impossível (sem antinomias fatais) "teoria" filosófica, expressão doravante equivalente a disparate ou mais tecnicamente "dogmatismo". É que pela primeira vez (continuo parafraseando o nosso último herói civilizador, Gérard Lebrun) entrava em cena um filósofo que não tinha mais parte com a ciência (até então a regra, desde Descartes e Leibniz, também "cientistas"), que em vez de produzir positivamente "conhecimentos", simplesmente refletia plantado numa terra de ninguém recém desbravada na exploração do juízo de gosto (que não é um juízo determinante de conhecimento, pois o "belo" não é um conceito, se me permitem o bê-a-bá), ou "pensava" visando "significações" sem se referir a "objetos" demarcados num território específico. Jogar ao mar a carga da "representação" era isto: cristalizada pela primeira vez num discurso autônomo, a Filosofia enquanto Forma (ou gênero) eliminava enfim a ilusão dogmática do referente ou das proposições decidíveis enunciando "verdades". Deixava, portanto, de "representar" ou de "figurar" o que quer que seja, salvo ela mesma apalpando-se "sentimentalmente", como vimos, enquanto em contrapartida mesmo o saber matemático (o mais formalizado) continuaria atrelado ao âmbito da "representação".

Não vem ao caso como, mas passando no livro seguinte para Hegel, Lebrun deu um jeito (engenhosíssimo) de empurrar de volta Kant para o arraial dos dogmáticos (já que os critérios agora são hegelianos, reflexão subjetiva e Entendimento convergem sob o signo da "finitude" a ser ultrapassada), e elevar Hegel à condição de primeiro filósofo absolutamente moderno (como queria o poeta): aqui de fato a derradeira pá de cal na "representação", na ideia (imaginária) de "conhecimento" (vide Althusser e Lacan), na "figuração" enfim. Estamos em plena vanguarda à francesa. E quando diz que a Dialética não é mais que uma "façon de parler", uma máquina discursiva de moer significações até elas confessarem que não são nada (e ponha ênfase nesse "nada"), Lebrun tem em mente, para facilitar a vida do leitor despertando-o para analogias que de fato estão no ar, a ruptura mais recente da pintura moderna com todo e qualquer ilusionismo perceptivo-naturalista enfeixado no termo genérico "figuração": é neste sentido 
que o discurso hegeliano, que vem a ser a Dialética, não "figura" mais ou, mais abstratamente, não "representa" mais, não "teoriza" mais sobre nenhum objeto, seja ele História, Estado, Direito, Arte, Lógica, Religião, o que for, ao contrário do lugar comum sobre o famigerado Sistema imperial hegeliano. Mas o símile predileto de Lebrun é menos a pintura do que a literatura, na mais específica acepção francesa do termo: um Hegel assim desdogmatizado, sem doutrina sobre coisa alguma, é tão incomensurável com os filósofos que o precederam quanto o não-figurativo Nouveau Roman confrontado com a prosa "representativa" dos grandes realistas oitocentistas.

Reparem então a espécie de paroxismo a que foi levada, nos termos mesmos de Lebrun, a filosofia enquanto forma autônoma, o que estamos chamando por nossa conta de filosofia profissional. Mas feita a observação, o quiproquó, em função do qual abusei do sobrevoo, salta aos olhos, se está certo o meu esquema, que aliás não por acaso também se beneficia da comparação com a evolução literária contemporânea da reversão social na origem do eclipse total da filosofia enquanto gênero culturalmente relevante: onde na periodização de Lebrun se apresenta no seu fastígio não-figurativo em estado puro, a revolução discursiva encarnada pela dialética hegeliana, nós podemos reconhecer o seu exato contrário, a "representação" filosófica do mundo elevada ao seu grau de abrangência máxima (e, já sabemos, terminal, decapitado pela força das coisas), na forma de um diagnóstico de época exposto (daí a "representação") categorialmente pelo nexo da negação determinada. Mesmo que Lebrun venha a acrescentar - como de fato irá fazer no livro seguinte, preparado expressamente para esse coup de Théâtre, O avesso da dialética - que é isso mesmo, que a dialética é isso mes- mo que dizia Hegel, ao falar da filosofia enquanto Teoria em sua acepção grega a mais enfática, essa visão retrospectiva que é uma época enquanto resultado histórico elevado ao plano do Conceito. Mas a ser assim é preciso então tomar ao pé da letra o que Hegel afirma da dialética como uma potência de Deus e reconhecer que nesse tal diagnóstico de época o ponto de vista da totalidade que ali se exprime é a velha aniquilação cristã do mundo finito, a culpabilização do devir inocente de qualquer teleologia, etc. - mesmo assim, repito, o curto-circuito não poderia ser maior, tanto no que concerne à periodização filosófica quanto à literária e a aparente correspondência entre as datas, a fratura de 48 no meio, volto a insistir.

MEC - Paulo! Aí está a deixa! Entra no Auerbach que você ficou devendo! Aproveita, meu!

PA - Agora sou eu que não quero deixar escapar o fio mais uma vez. Não podemos perder de vista o camarada bisonho na sua mesa de trabalho em Paris, informado da existência do Brasil beirando os trinta anos, sem no entanto ter a menor ideia da contingência cultural que ao mesmo tempo o inocentava (em parte) de tamanha parvoíce e o habilitava - a sorte ajudando - a redigir uma tese honnorable sobre Hegel, ilustrando, como lhe competia, a função civilizadora da especialização em filosofia no seu país. Imaginem: ainda por cima o infeliz fazia beatamente uma tese sobre Hegel, agravando o quadro de miopia histórica aguda que era o seu. Por isso a leitura de Lebrun volta e meia lhe queimava os fusíveis, sem saber por quê. Não tinha a mais remota noção do que se passava, salvo o ânimo combativo uspiano por fidelidade ao autor de Contra Althusser de jamais entregar a dimensão ontológica da 
Dialética. Por outro lado, mesmo que tivesse alguma notícia do dilema que acabamos de evocar (coisa de fato impensável naquele momento de falsa consciência filosófica máxima, sem falar no déficit desalentador de percepção social e o seu correspondente filtro literário, já que era esta a experiência estética predominante na tradição cultural da qual não sabia que descendia), o professor Lebrun àquela altura se encarregava de trocar as bolas e baralhar as pistas.

Volto ao raciocínio anterior, do qual ignora tudo o nosso memorando, como vocês dizem: a filosofia "figurativa" com a qual sonhava um João Cruz Costa (só não dou outros nomes da velha guarda não-uspiana para não enrolar mais o novelo, mas precisarei uma hora dessas passar por aí) mal nascera com Hegel e já estava morta e enterrada pela luta de classes, e não obstante era do subproduto profissional dela, a metade kantiana que Hegel deixara para trás, do que mais carecíamos, no capítulo, indispensável em país colonial, "melhoramento-da-vida-moderna”, qualquer outro sucedâneo (revival neo-hegeliano, filosofia popular do tipo positivismo, spencerismo, pragmatismo, existencialismo, marxismo visão-de-mundo, etc.) logo resvalaria para a conversa edificante, de cujas variantes locais queríamos distância. Assim, não dispondo dessa faculdade de configuração da matéria bruta ambiente desde que com Hegel o gênero se inviabilizara, tal a altura de que o apeara o curso do mundo, a filosofia nada tinha de equivalente (à representação literária do mundo) a oferecer, salvo o prestígio muito confinado da última palavra, sobre o quê exatamente ninguém sabia ao certo - e olhem que ainda não tínhamos nos animado a pular a cerca do chiqueirinho filosófico. Ora, o dilema nem nascera, quando muito era ressentido à distância e sem conceito, e o nosso amigo Lebrun já estava provando por a + b que o último filósofo era na verdade o primeiro profissional, ainda por cima por ser de vanguarda (antes de mostrar a cara de niilista cristão), contemporâneo exato da idade pós-realista da literatura. O que alimentava o fogo cruzado do quiproquó? De parte a parte, continuar batendo na mesma tecla desafinada da filosofia: fosse ela configuração do mundo ou não (os mais atualizados na mesma ilusão diriam: "discurso filosófico da modernidade" ou não; o "não" aqui teria a ver com a finada era da filosofia analítica, cujo passado se pode fazer remontar aos primeiros argumentos "profissionais" de Descartes, uma boa observação que não se pode deixar de creditar ao Richard Rorty), era página virada, enquanto a representação literária da realidade, antes ou depois da crise da objetividade literária, persistia como problema vivo, para não falar na sua função histórica de organização da experiência intelectual brasileira, tanto na fase da literatura de incorporação quanto na de depuração, recorrendo novamente à distinção preciosa de Antonio Candido.

MEC - Última chamada. Olha aí a deixa: por que o problema da representação ou apresentação literária da realidade continua de pé, e o possível equivalente filosófico entrou em parafuso?

PA - Agora a coisa mudou de figura, pois a deixa foi você quem acabou de me dar. Pois repare que a sua formulação acaba de enterrar qualquer veleidade que eu porventura alimentasse (fantasias de onipotência à parte) de parir uma Mimesis filosófica, mesmo que só raciocinando para efeito programático-demonstrativo. Foi isso mesmo que me passou pela cabeça quando a inconfidência mui- 
to simpática do Bento veio à baila: mostrar o equívoco de raiz na base do projeto. Como desfazê-lo importaria em acrescentar alguns tijolinhos mais no meu esquema "fim da filosofia bidimensional de corte hegeliano por motivo de colapso da cultura burguesa conflagrada pela luta de classes/mudança de campo do interesse pela Totalidade/ demarcação social da filosofia profissional", vamos então à digressão.

CR - Sem pressa, pois o Dr. Fernando, generosamente resignado, liberou fita e papel. O nosso tempo, de qualquer jeito, é de graça mesmo.

PA - Então vamos à enormidade que me ocorreu a uns dez anos atrás, da maneira a mais singela possível. (Pela minha mania contábil, a Maria Elisa já deve ter calculado que o peixe que eu estou querendo lhes vender foi pescado não faz muito tempo: desasnar custa mesmo, e olhe que não tem me faltado ajuda nesses anos todos). Enormidade, seja dito também entre parênteses, porque naquela minha veleidade havia, quase por definição, pouquíssimo conhecimento de causa no que concernia a verdadeira índole do livro.

MEC - Que mal pergunte: por que exatamente Auerbach?

PA - Por uma razão de bom tamanho que daqui a pouco já explico, igualmente um equívoco de minha parte, porém produtivo. E por uma outra à primeira vista, mas só à primeira vista, até que sensata ou pelo menos eventualmente útil: é que sendo um professor no mínimo desastrado e naquele momento começando a dar aula pela primeira vez na vida no primeiro ano (e já que estamos balizando tudo: foi justamente nesta circunstância que estreei, em 1982, lembrando um pouquinho por extenso aos calouros por que não podiam encarar com naturalidade num país como o Brasil cuidar de filosofia em tempo integral), estava à procura de uma maneira de apresentar ao meu novo público cativo a tradição filosófica de A a Z, embora para tanto não estivesse apercebido, como gosta de dizer o eminente historiador Fernando Novais. Ao mesmo tempo estava igualmente à procura de um substitutivo mais animado para o tipo de explication de texte corrente na casa, achei então que a filologia do Auerbach seria um bom modelo. Aqui o primeiro tropeço, a grande encrenca que nenhuma erudição do mundo poderia evitar, pois está claro que o dado elementar de que eu nem de longe tinha na cabeça todo o álbum de figurinhas filosóficas de Platão a Heidegger não vinha sequer ao caso, nem mesmo era uma objeção, já que outro qualquer mais apercebido poderia executar o serviço. Como era do meu dever de materialista vulgar assumido, andava atrás de uma brecha que me permitisse exibir o nexo interno à armação filosófica dos conceitos e processo social, na suposição de que nesta articulação imanente se encontrava a chave de interpretação dos sistemas. Ora, o equivalente literário deste vínculo não estava disponível de forma divinamente elaborada num livro como Mimesis? Sim e não. Acho que mais "não" do que "sim".

Mas o meu lapso mortal era outro: imaginar sem maiores considerandos que havia livre trânsito entre a relação buscada (por mim) rejuntando filosofia e sociedade (pecado sem remissão segundo o evangelho da casa, pois aliava dogmatismo e método genético, na terminologia de Goldschmidt) e o que Auerbach entendia por representação literária da realidade, ou mais enfaticamente "imitação", quer dizer, a interpretação da realidade através da 
sua representação literária. Simplesmente me enrosquei nas impropriedades evidentes desse amálgama. Assim, o que poderia ser "realismo sério" em filosofia? O que poderia ser enfim o equivalente filosófico da ideia de "imitação" literária da realidade, descartada a hipótese inepta de uma comparação automática com a noção corriqueira de realismo filosófico? Do lado literário: representação, exposição, apresentação da realidade, sem, no entanto, algo correspondente no plano filosófico, não obstante serem tais termos de origem filosófica no sentido mais amplo do termo. Realidade representada literariamente? Dá para entender. Filosoficamente? Aí as coisas se complicam. Repito: é que no primeiro caso sempre se passa algo como uma "figuração", enquanto a filosofia a rigor não "mostra" nada. Isto sem falar na questão correlata e crucial da separação estilística e sua mescla posterior: onde o "superior" e o "baixo" na tradição filosófica, a ser encadeada por amostragem como em Auerbach?

ICC - Isso está me cheirando a tópico de colóquio, tipo “As relações de afinidade e repulsa recíproca entre Literatura e Filosofia"...

MEC - Ô Iná, não seja antigona. O tal de linguistic turn tanto em filosofia quanto na teoria literária acha que rejuvenesceu essa querela de barbas brancas. Até onde eu sei, sobretudo pela atual polêmica americana, o Habermas volta e meia relembra que a fuga dos desconstrucionistas para o "textualismo", ou para o nivelamento da diferença de gênero entre filosofia e literatura, se explica por se furtarem às exigências da fundamentação próprias do contexto moderno de justificação argumentativa. Não é isso, Professor?
PA - Perfeitamente. Pelo visto, estou sobrando aqui. Professor por professor, então um esclarecimento preliminar. Qualquer preâmbulo de paper a respeito fará remontar o contencioso em questão até a Antiguidade (se for um paper francês, acompanhará Foucault até a Sofística e sua desconexão entre as palavras e as coisas para celebrar ali naquelas paragens remotas anteriores à normalização da ratio grega o nascimento ultramoderno da literatura, etc.). Mais precisamente, dependendo do gosto, ora à condenação da Poesia por Platão, quer dizer, denúncia de um simulacro em nome de uma concepção enfática de verdade, ora à distinção aristotélica entre Lógica e Retórica, em detrimento desta última, sempre que estiver em jogo a causa mais nobre do conhecimento. Não faltará por certo quem observe por ocasião dessas manobras preliminares que, não obstante e tudo bem pesado, Platão escrevia divinamente e que Aristóteles, mesmo sendo ordinariamente prosaico como todo homem de ciência, arrumou um jeito de situar a Dialética, uma forma sem dúvida híbrida, na terra de ninguém das sondagens das "significações" (ou "essências") sem o apoio de princípios evidentes ou demonstrados, enfim algo próximo da ainda muito longínqua invenção moderna do transcendental. Deixo de lado este último ponto, aliás a esta altura bastante familiar pois essa invenção é recente e vem a ser a da filosofia profissional, especializada, como já sabemos nós, a priori das condições de possibilidade, etc. Ora, mesmo levando-se em conta o possível cabimento de observações desse quilate, o anacronismo delas não poderia ser maior. É que Filosofia e Literatura não têm a mesma idade cultural: foi preciso que a primeira se transformasse, de dogmática ou "ingênua" em "sentimental", como já sabemos, a partir de Kant, e a consciência histórica da segunda se 
cristalizasse (segundo a ideologia literária francesa, para recorrer a uma baliza bem conhecida, esse grau zero dataria de Mallarmé, sendo apenas Belas Letras e não Literatura tudo o mais que vinha antes) para que os caminhos de uma e outra finalmente se cruzassem com algum conhecimento de causa. Não custa recordar que já passamos por esse primeiro entrecruzamento, reparando mais uma vez que a invenção kantiana da filosofia "tecnicamente" profissional é contemporânea do processo estético-social de autonomização da obra de arte, registro "logicamente" lavrado, de resto, na teoria kantiana do caráter reflexionante do juízo de gosto. Enfim, arte autônoma e filosofia profissional têm a mesma idade no calendário da divisão social do trabalho intelectual enquanto culturas separadas no mundo compartimentado dos especialistas. Também já tratamos disso, mas agora azar.

Voltemos então ao nosso problema inicial. Na intenção de refazer a história da representação literária da realidade no Ocidente, Auerbach não viu nenhum inconveniente em começar por Homero e terminar com Virginia Woolf. Deixando por enquanto de lado a questão que verdadeiramente nos interessa, a da hierarquia e mistura dos níveis estilísticos na explicação do Realismo, é preciso registrar de saída que só mesmo uma concepção filológica de abrangência máxima, inimaginável nos dias de hoje, não só pela erudição insuperável porque bem calibrada e por isso mesmo capaz de dar os passos modernos em perspectiva e contiguidade com a tradição antiga e medieval, como de resto em Robert Curtius, por exemplo, só mesmo um horizonte amplo nesses termos pode abrigar sob a mesma rubrica literária obras tão díspares como a abertura e o fecho que acabamos de recordar, quando muito justapostos na forma de paródia como fez Joyce no Ulisses. Ao que parece, o fato é que o abalo modernista deve ter obscurecido nossa percepção dessa grande continuidade, ninguém mais está em condições de raciocinar nesses termos.

MEC - Ora, ora, ora. Deixe que eu antecipo seu próximo passo, livrando-o do constrangimento de se repetir. A seguir viria, segundo as minhas anotações: fica cancelada no berço qualquer Mimesis filosófica, pela simples razão de que o arco Platão/Heidegger é uma construção ideológica, aliás habilmente alimentada não só pela paranoia do alemão aí (gente: só pode ser coisa de paranoico um negócio chamado "Platão e Eu sobre a Verdade", né?), mas também pela atual voga desconstrucionista, com todo mundo formando lisonjeiramente na linha de frente do combate ao Cânon. No caso dos filósofos, aliás incorporados pelos profissionais dos estudos literários (estou pensando, é claro, nos americanos e sua imensa colônia multinacional), combate à herança logocêntrica da onipresente Metafísica do Ocidente, como prega o Frère Jacques. Nesse entrevero, o pobre Auerbach deve sair com fama de onto-teólogo-da-Presença-da-Origem, etc. Porque, como eles ensinam, realismo sério é coisa de cristão, macho, branco, ocidental, etc. Além do mais, a classe aqui presente, não sendo propriamente tapada (nunca se sabe...), manda avisar que entendeu muito bem que você não quis dizer pra gente prestar atenção no fato de que filosofia se diz em muitos sentidos: uma coisa é um filósofo grego; outra, um teólogo medieval; outra, um philosophe iluminista; outra, um idealista alemão ou a sua anêmica descendência profissional no fim do século passado; outra, enfim, alguém da espécie brasileira, tipo franco-uspiano, etc. Até aqui está certa a lição de casa, professor? 
PA - Parece...

CR - Mas, afinal, o que foi que nós entendemos, mesmo?

MEC - Bom, aí a gente pode negociar. Basicamente, só para repisar o ponto da prova: que o distinto Professor teria feito o foco de sua periodização recair num episódio à primeira vista tão descaradamente extrínseco quanto o primeiro grande desfecho dramático da luta de classes no paleocapitalismo de meados do século passado. Primeiro, por ser de fato decisiva e conclusiva essa virada em que a apreensão possível do processo na sua integridade, que também atende pelo nome de Totalidade (sempre com o perdão da má palavra), passa para o campo social oposto e muda de forma - já sabemos que essa forma se encontra tanto na Crítica da Economia Política quanto na estética antiburguesa que inspira a arte burguesa escaldada pela revelação recente da guerra civil.

\section{ICC - Nossa! Ela fez direitinho a lição de casa!}

MEC - Agradeço o incentivo, mas gostaria de concluir à maneira dos resumos do nosso memorando: se entendi mesmo, essa reviravolta terminal não teria ocorrido, ou melhor, nem sequer seria inteligível se deixássemos escapar, por um lado, a condição de gênero, digamos tradicional, ou mesmo pré-capitalista, que no fundo vem a ser a filosofia, com toda a sua carga por assim dizer salvífica sedimentada no nexo orgânico entre teoria e vida ativa. E que, por outro lado, foi portanto surpreendida pelo referido revertério que está na origem da decadência burguesa (para falar como Lukács) no exato momento em que, como os demais gêneros literários clássicos sobre os quais Goethe, Schiller e Cia. meditavam com o propósito de imaginar-lhes um equivalente ajustável aos tempos modernos em princípio hostis, pela realidade mesquinha dos assuntos possíveis (bem feito! quem manda não morar na Inglaterra?), à elevação das antigas formas, a começar pela epopeia, parecia ter encontrado (pensando sempre no desfecho hegeliano) a fórmula revitalizadora da Vida Teórica à antiga e suas implicações práticas, reencontro da dita cuja e seu recheio de categorias com o material de segunda fornecido pelo novo estado do mundo...

ICC - Com licença, mas eu preciso acrescentar à judiciosa observação da colega que também não se trata de rebater no continuum imaginário Platão/Heidegger a óbvia distância sociológica entre um maitre-à-pense ateniense do século IV e um mandarim alemão de entreguerras. Além disso, por mais que o último Heidegger alimente a fantasia da pré-socrática rediviva no país mais industrializado da Europa, sempre que aproxima filósofos e poetas, não por acaso o sistema de afinidades que armou para uso próprio se estende de Hölderlin a Rilke, balizas de um périplo elegíaco induzido pela queda traumática na modernidade burguesa.

PA - Descompasso dos dois lados, portanto. Mas antes de verificarmos de que modo poderíamos fazer funcionar esse desencontro, consideremos por um instante, no intuito de salientar melhor o contraste, um desenvolvimento possível do anacronismo por analogia que estou procurando evitar, no caso, entre as duas séries paralelas, da Odisseia à Viagem ao Farol, de um lado, e do outro, dos Diálogos platônicos ao Ser e Tempo. Se quisermos só por um momento imaginar algo como um contraponto 
entre ambas, por que não pensar por exemplo no quadro conceitual em que o jovem Lukács situou sua primeira Teoria do Romance? Mais particularmente, estou pensando na evolução da narrativa épica balizada pela oposição, nos termos dele, entre essência e vida, significação e existência, uma evolução marcada, como se sabe, pela passagem nefasta do concreto para o abstrato, pelo declínio da experiência (mas agora nos termos mais ou menos contemporâneos de Walter Benjamin) na transição das sociedades tradicionais para as modernas. Como narrar em condições tão adversas? Como seria possível uma epopeia num mundo abandonado de Deus? Pergunta de um moderno confrontado com o novo rumo da alienação. Quer dizer: com o divórcio entre sentido e curso desencantado do mundo, um balanço comandado pela confluência entre a sociologia clássica alemã de Tönnies a Weber (cujo assunto era esse processo mesmo, essa experiência negativa da modernização) e uma certa filosofia da vida (subproduto da demarcação institucional da filosofia, correndo por fora numa espécie de raia pavimentada pelo mal estar na sociedade burguesa e seu cortejo de mitologias compensatórias, da Intuição à Existência) impregnada de vagos sentimentos anticapitalistas. No centro a fórmula hegeliana, que aliás nem precisava ser enunciada explicitamente, compêndio do esforço, há pouco lembrado muito a propósito, para aclimatar as formas nobres da Antiguidade à matéria cinzenta da nova ordem social, segundo a qual (fórmula) o Romance vinha a ser justamente a epopeia ajustada ao horizonte raso da civilização burguesa. Decifrar o destino vindouro dessa Forma, cujo eixo era a narração, dependia do juízo acerca da distância que nos separa da antiga plenitude do epos homérico. Ora, é precisamente no interior dessa constelação que o primeiro
Lukács pensava a filosofia platônica, justamente definida pelo confronto com o poema épico. Neste caso, portanto, Poesia e Pensamento são aparentemente comensuráveis, porém com uma ressalva capital: a equiparação se dá unicamente em função do reconhecimento do primado da narrativa épica, que a imanência do sentido na vida coletiva tornava possível, totalidade de cuja cisão irreparável a filosofia platônica é justamente o registro e elaboração compensatória. De um lado o mundo sublunar exaurido e opaco (e por isso mesmo objeto da manipulação desenvolta da sofística “esclarecida”); do outro, o céu inteligível das Ideias, pátria transcendental do sentido à qual a alma exilada poderá retornar caso tome a via ascética e ascendente da "teoria" filosófica (na acepção forte do termo).

Ocorre que segundo o Lukács desse primeiro período trata-se de um expediente extremo, porém inócuo: só a narrativa, e cada vez menos, em nenhum caso o discurso filosófico, mesmo o mais sublime de todos, poderia recompor o sentido de outro modo ameaçado de extinção. Até onde me lembro, o Jameson (Fredric) foi o primeiro a chamar a atenção para esse contraponto de origem entre Filosofia e Literatura (devidamente especificada, como acabamos de ver), para melhor destacar então o lugar central ocupado pela Narração ao longo de toda a obra de Lukács. Se tomássemos esse caminho e, portanto, mudássemos de rumo, já sabemos que seria então o caso de rever essa mesma constelação de configuração épica e reconstrução filosófica certamente no seu momento hegeliano (terminal, segundo o nosso esquema): a saber, tornar o mundo narrável, como logo se proporá a fazer a grande prosa do realismo literário oitocentista, e elevar a experiência do presente ao plano do conceito, como compete a uma filosofia à altura do seu tempo e fiel à noção especu- 
lativa de Teoria, serão operações conjugadas e de mesma índole? Mas em seguida precisaríamos rastrear esta possível confluência no Lukács do balanço conclusivo de História e consciência de classe, onde Narração e Totalidade voltam a se confrontar e se reunir graças à força cristalizadora de uma Revolução. Mas àquela altura a Filosofia já seria coisa do passado, porém no momento mesmo de sua abolição teria deixado claro seu vínculo congênito com a recapitulação épica, que a primeira Teoria lukacsiana do Romance entrevira, embora no modo da incompatibilidade. Anacronismo? Como mudamos inteiramente de registro, a alegação deixou de ser esclarecedora pois agora a nossa relação com a tradição é outra.

ICC - No Auerbach não tem nem sombra disso. E não é por acaso. Aliás, sempre me intrigou esse impressionante tirocínio literário, ao lado de lacunas espantosas, que me deixam louca da vida. Vou direto à que me parece a mais gritante e acho que está por trás da digressão do Paulo sobre esse Lukács. Mas também já vou avisando que as especulações eruditas em torno das origens da noção de "figura" em Auerbach, se ele é ou não tributário de velhas concepções patrísticas mais ou menos alegorizantes, bem como as "n" concepções de "mimesis", de Platão aos nossos dias, toda essa enrolação, não me interessa a mínima. Muito bem, podemos pular essa parte. Não sei se vocês concordam que o livro chega ao seu apogeu temático - mas não estético, que a meu ver se verifica no capítulo sobre Dante e o "realismo figural" - no século XIX e, mais particularmente, com o realismo francês, no caso, Stendhal, Balzac e Flaubert. E não obstante tudo isso, nem uma palaura sequer sobre o fundamento histórico do realismo estético. Posso estar redondamente enganada (nesse capí- tulo acho que não), mas não dá para dissociar - e aqui se trata de pura e simples omissão - algo que ele não leva em conta: a cristalização da representação séria da realidade social cotidiana contemporânea do poder estruturante da transição capitalista em curso. E mais: a famigerada mescla estilística que puxa a reconstrução do Auerbach como um ímã, e finalmente se impõe com os grandes realistas franceses, sem a mola propulsora da luta de classes. Pois o que mais poderia deslocar a visão literária da vida que mandava desqualificar os já socialmente desclassificados senão a pressão dos de baixo? O que forçou as portas de uma sociedade estamental como a do Antigo Regime e seu classicismo literário sem qualquer concessão ao decoro nobilitador, sem falar no sentimentalismo lacrimejante que o sucedeu, elevando personagens corriqueiros e suas circunstâncias históricas não menos efêmeras à condição de objetos dignos de representação artística séria, problemática e mesmo trágica, insisto, senão a bendita luta de classes?

\section{CR - Mas o meu editado embarcou nessa canoa furada?}

PA - De qualquer modo, uma bela canoa. E os grandes furos são esses mesmos nos quais a Iná pôs o dedo. Dedo, aliás, brechtiano, de quem está muito bem lembrado de que o palco só começou a narrar, no princípio aos trancos e barrancos, com o Gerhart Hauptmann, depois que a massa insurreta dos tecelões da Silésia entrou em cena. Mas é claro que o Auerbach tinha notícia dessa enorme mutação histórica. Sendo, no entanto, um liberal convicto, porém ao modo da velha burguesia alemã de cultura, e na Alemanha imperial, e mesmo durante a República de Weimar, isto não era em absoluto pouca coisa, percebeu 
aquela grande transformação como uma espécie de ponto culminante de uma longa marcha na direção da Democracia. Até onde sei, o primeiro a dizer isto com todas as letras foi o Leo Spitzer no ensaio famoso sobre a enumeração caótica na poesia moderna, anarquia turbilhonar que toma como a configuração verbal da civilização moderna em ruptura com o mundo tradicional, daí o caos característico da euforia com a emancipação recém conquistada. Pois essa Musa Democrática que irmana nos mesmos direitos pessoas, palavras e coisas, Spitzer acha que também ela preside ao progresso da mescla estilística estudada por Auerbach, entendendo a quebra da hierarquia literária como o índice estético das fronteiras transpostas entre as classes sociais, patente no reconhecimento do que pode haver de trágico na existência cotidiana do homem médio circundado por coisas médias, etc.

Canoa furada? Mas que canoa! É só reconsiderar tudo o que ele viu, guiado exclusivamente pelo seu sexto sentido de estilista, no momento decisivo do livro (depois do capítulo sobre Dante, uma espécie de suma premonitória da fusão moderna da mescla estilística com algo como uma visão místico-realista), as páginas sobre Flaubert. Está tudo ali, magistralmente condensado em meia dúzia de páginas, salvo a razão da cena exposta, no caso a radical mudança de registro da luta de classes, dos tempos grandiloquentes e melodramáticos de um Balzac, bons tempos de antes do fiasco clamoroso da fraseologia burguesa e que por isso mesmo autorizavam a intromissão opinativa de um narrador nadando a favor da corrente, para os tempos de reação violenta a esse tipo de efusão agora sob suspeita, de sorte que a imitação séria do cotidiano precisa ser doravante imparcial, ignorando a pretensa distinção entre objetos elevados e baixos, por certo, mas agora de uma maneira apartidária, impessoal, honestamente equidistante de todos os pontos de vista em confronto. Auerbach viu tudo lendo Madame Bovary, menos que os massacres de junho de 1848 arrastaram para o abismo a finada normalidade burguesa, e nesse sentido entendeu e acompanhou piamente as razões de Flaubert, achando que de fato a honesta confiança irrestrita do artista na verdade da linguagem expurgada dos significados comuns e do correspondente lixo opinativo faria sem exceção justiça a tudo e a todos.

Assim, a primeira grande leitura contemporânea de Flaubert (mesmo pensando nas linhas de Proust sobre o estilo de Flaubert, ou no livro de Thibaudet) viu enfim consumada a democracia literária por mescla estilística onde havia, sem diminuição alguma do valor estético, é óbvio, congelamento do ódio social das classes confrontadas, paralisia estilizada na objetividade da forma integralmente composta. De modo que nos seus efeitos, admiravelmente descritos, não poderia ser mais eloquente a presença ignorada da guerra de classes no centro de uma história da representação literária da realidade.

Dito isso, é preciso acrescentar outro episódio que interessa à marcha lenta deste "nosso memorando". Eu também só fui instruído a respeito muito tarde, depois de pacientemente doutrinado em meados dos anos 80 por Roberto Schwarz e Modesto Carone, no momento digerindo os livros de Dolf Oehler sobre o modo pelo qual os grandes escritores do Segundo Império transpuseram para os seus procedimentos compositivos os acontecimentos que redundaram no estado de sítio moral sob o qual passaram a viver as capacidades intelectuais do período. A esse respeito eu ainda rezava pela cartilha sartriana do Idiot de la Famille, sem falar no Lukács de Narrar ou descrever? 
dilema que também girava em torno da fratura de 1848, e dez anos antes havia combinado os dois modelos na tentativa de situar no âmbito da "neurose objetiva" da burguesia europeia de meados do oitocentos a crítica da filosofia da história em Schopenhauer. O meu esqueminha, assim, vinha de antes, mas andava enfiando filósofos e escritores na mesma vala comum da irrelevância descritiva. (No que reproduzia as restrições do jovem Schwarz da Sereia e o desconfiado aos autores dedicados à elaboração estética da crise da objetividade literária). Ajudaram-me a sair do desvio em que estava parado os dois amigos mencionados. Renovei o esquema conforme venho dizendo: o mesmo colapso da normalidade burguesa que, graças à nova objetividade do dispositivo técnico, cavada no sentido que acabamos de ver, obrigou os escritores (Flaubert, Henry James, etc.) a transformar virtualidades canceladas do seu material em outras tantas possibilidades históricas de "representação", sepultou de vez as chances de sobrevida culturalmente relevante da filosofia enquanto forma específica.

Neste ponto, uma mãozinha do mesmo Roberto para a datação do referido atestado de óbito da filosofia, cujo ponto de vista, passado a limpo, no sentido já indicado, emigrou para o campo popular derrotado em 48, comprovando (nas palavras do nosso Autor, e como já o fizera o Lukács de História e consciência de classe) que o primado doravante indescartável da inteligência social inaugura um horizonte epistemologicamente novo. Estou pensando numa antiga promessa que o Roberto ainda há de cumprir, a de mostrar (não exatamente assim como estou dizendo, imagino) que a revelação do colapso que modificou o rumo da tendência histórica do material literário na direção indicada por Flaubert, supondo é claro que esta revelação tenha ocorrido exatamente com O Dezoito Brumário, se deu exatamente através de um raciocínio inédito porém análogo, já pela composição do enredo encarregada de pôr em cena as grandes mentiras e carreiras ideológicas como cifra do presente, às construções "realistas" de Balzac, justamente o principal porta-voz literário do período anterior que estava sendo inviabilizado, mas cujo ponto de vista, retomado noutro patamar, podia abarcar o conjunto da cena inédita em que transcorria a crise. Onde a filosofia capaz naquele momento de semelhante golpe de vista?

CR-Até aí tudo bem. Mas ainda não está respondida a pergunta que também me interessa: por que Auerbach? Você disse que havia uma boa razão para cogitar uma Mimesis filosófica, que afinal não deu em nada - além de atrasar um pouco a nossa conversa...

PA - Porque era um dos livros prediletos do Antonio Candido, descartado, é evidente, qualquer compromisso com as implicações da teoria geral dos níveis estilísticos, como é sabidamente do feitio do nosso Crítico. E como eu estava à procura de um pé de apoio na experiência brasileira, achei (mas só aprendi quando a pus de lado) que a mera hipótese de "uma história da realidade representada na filosofia do Ocidente" seria uma oportunidade de entrar em linha com a constelação intelectual dos que aprenderam a pensar refletindo sobre o Brasil. Mas agora que toquei no assunto, não posso passar adiante sem um par de esclarecimentos, sempre na intenção dos mais jovens. Aliás nesta mesma intenção, recomendo-lhes de saída a leitura de um breve estudo recolhido em Recortes onde, a pretexto de Marcel Proust e do pastiche, no último volume da Re- 
cherche, de um trecho imaginário do diário dos Irmãos Goncourt sobre o Salão Verdurin, cuja realidade conhecemos pelos "olhos" do Narrador, que ironicamente se penitencia por não ter sabido ver o que os dois irmãos "realistas" enxergaram no casal Verdurin e seus fiéis, Antonio Candido procede a uma espécie de demarcação do terreno em que prosperam os equívocos a respeito do realismo e da representação mimética do mundo. Se estritamente concebido o primeiro, no caso por exemplo da supremacia da função referencial sobre a estrutural no que concerne à especificação dos dados de realidade, perde-se o essencial buscado pela imitatio em questão, no exemplo proustiano, uma visão que não se detém na superfície, discrimina em perspectiva as impressões, correlacionando-as em virtude de um princípio integrador responsável pela transformação de uma chuva de pormenores na expressão verdadeira e mais alta do universal ancorado na particularidade.

Aqui, duas observações, também para governo da novíssima geração. Num ensaio dos anos 1970, sobre o Assommoir de Zola, Antonio Candido, contrariando abertamente as prevenções de Lukács a respeito da estreiteza meramente descritiva dos escritores pós-1848, mostrou de que modo a descrição assume importância fundamental na instituição da narrativa, de que modo descrever é narrar. No outro estudo de que falamos, volta a equilibrar o jogo (demonstração suplementar de que não se trata em Lukács de uma alternativa simplista diante da qual se possa tomar partido a favor ou contra uma das pontas do dilema), pois a desqualificação proustiana do realismo descritivo dos "naturalistas" Goncourt é feita em nome de uma narração que articula em profundidade algo como uma totalidade.
Agora, dizer mais especificamente que figuras pode assumir esta última depois da referida crise da objetividade literária que redundou no momento antirrealista do romance, que por fidelidade ao seu impulso realista original precisou renunciar à reprodução do movimento aparente da sociedade, isso, é claro, são outros quinhentos que apenas lembrei para introduzir minha segunda observação, a saber: favor notar que Antonio Candido, encaminhando desta maneira a discussão do Realismo (um outro apanhado deste mesmo método dos contrários, exercido ao vivo na elucidação do problema da representação literária da realidade, pode ser encontrado na explicação preliminar que abre o Discurso e a cidade, a propósito do paradoxo que vincula na mesma impressão de realidade verdadeira tanto romances de forte notação documentária que no entanto deslizam para imagens transfiguradoras, quanto as narrativas que boiam livremente acima do referido compromisso mimético de primeiro grau e, não obstante, mais uma vez cravando na metodologia dos contrários, transmitem um profundo sentimento de vida), evolui perfeitamente à vontade num mundo em que a própria alienação tornou-se ela mesma mediação estética, mundo pós-realista que Auerbach já não compreendia mais, como se depreende do clima de fim de festa que impregna o último capítulo de sua obra prima.

De resto uma discussão imperativa, essa do Realismo, haja vista a trilha duvidosa por onde corria o desejo nacional de ter uma literatura, a do pequeno realismo sentimental de impregnação obrigatória pela cor local, por motivo de consolidação do autoconhecimento de um país novo; daí o interesse do Crítico em identificar linhagens alternativas de maturidade em que o efeito estilístico da verdade literária buscada não dependesse mais da fideli- 
dade documentária ao nosso conteúdo de experiência. Há mais ainda no capítulo Auerbach/Antonio Candido, do qual podem ser vistas como apêndice muito lateral minhas veleidades em torno de uma Mímesis filosófica. Sou de opinião (e creio que não só eu) que também deve ter falado à imaginaçõo literária de Antonio Candido aquela ideia chave, segundo a qual a mescla estilística responsável pelo realismo sério inspirava uma espécie de visão democrática do desenvolvimento histórico: pois acho que Antonio Candido pode muito bem ter revisto os achados de Auerbach à luz da tradição radical, por ele mesmo identificada e estudada nas mais variadas circunstâncias, que acrescentava ao fardo já muito sobrecarregado do homem culto brasileiro a missão de incorporar política e literariamente à sociedade a massa do povo miúdo, marginalizado e espoliado - tarefa que o colapso mundial de nossa modernização capitalista abortou de vez, nunca será demais lembrar nos tempos que correm. Duas contraprovas desse palpite. Consta, como aliás todo mundo sabe, que Antonio Candido certa vez teria concebido o projeto de escrever algo como uma Mimesis brasileira (coisa que evidentemente jamais apresentaria nesses termos, para ele certamente descabidos), da qual de fato conhecemos os dois primeiros capítulos, se é verdade que o resto permaneceu em estado de caderno: a Dialética da Malandragem, estudo das Memórias de um Sargento de Milícias, e o ensaio seguinte sobre O Cortiço. Com uma novidade decisiva em relação a Auerbach: é que jamais ocorreria a este último que a decifração do "realismo sério" estava condenada a ficar no meio do caminho caso deixasse sem investigar o modo pelo qual se estruturaria o processo social correspondente à mescla estilística problematizante. $\mathrm{O}$ que o nosso Crítico precisou fazer, e conseguiu, como demons- trou de uma vez por todas o Roberto Schwarz nos dois estudos que dedicou àqueles ensaios históricos.

Então, por que Auerbach? Mesmo como fonte remota de inspiração? Se entendi bem uma conversa com o mesmo Roberto Schwarz, daria para conceber nos seguintes termos os dois principais passos dados por Antonio Candido: no primeiro, o da Formação stricto sensu, o crítico reconstituíra sem aderir, até carregara levemente na ironia, o projeto de nossas classes dominantes de dotar a ex-colônia de um aparato literário que cumprisse suas funções civilizatórias, reconstituição de onde as camadas subalternas a bem dizer estavam ausentes, bem como os efeitos estruturantes da persistência do antigo regime colonial na nação independente porém de economia reflexa; ora, os de baixo, o povo miúdo sangrado e capado (para falar como Capistrano de Abreu) finalmente irrompe na cena literária brasileira no passo seguinte do Crítico, ao qual correspondem justamente os dois capítulos conhecidos da nossa Mimesis, uma história literária cujo foco narrativo é dado pela perspectiva dos pobres, o alter ego da nossa grande família de "radicais".

Aqui a segunda contraprova de que falei. Estou pensando no Manuel Bandeira do Davi (Arrigucci Jr.) que não por acaso se apoia muito a propósito na lição de Auerbach acerca do sermo humilis para explicar, mas de um modo agora materialista, sem Eterno na manjedoura, como Manuel Bandeira desoculta a emoção poética mais alta e sublime entranhada na vida terra-a-terra dos homens cotidianos. Ora, aqui em funcionamento novamente a visão literária democrática que acompanha a teoria da mescla estilística e a consequente quebra da ênfase monumental do estilo elevado que foi um dos cavalos de batalha do nosso Modernismo, pois o estilo humilde por assim dizer 
confraterniza com a camada espoliada dos pobres, mas não uma vaga simpatia à toa, pois seguindo a lição do outro mestre, Davi procurou mostrar de que modo a relação com a pobreza passa a ser um fator interno de estruturação da obra poética de Manuel Bandeira. Assim, Auerbach, quem diria, um fino humanista alemão, sancionando inesperadas (e complicadas) alianças de classe insinuadas por nossos poetas modernistas.

MEC - Mal acompanhado é que o senhor não estaria, caso a filosofia não tivesse falido em seu antigo propósito de "representar" o mundo. Tadinho!

PA - Antigo propósito, vírgula. A esta altura me candidato a linchamento se continuar a repisar, mas agora fui provocado. No que diz respeito à finada filosofia enquanto guardiã da integridade do processo (acho que a paráfrase dá alguma ideia do abismo que nos separa do texto filosófico antes da queda: pois é o nosso amigo Habermas quem gosta, faute de mieux, de nomear a filosofia guardiã da racionalidade, só que "em geral", isto é, no seu revestimento linguístico), volto a bater na mesma tecla: tal propósito, embora fiel à ideia antiga de Teoria e seu vínculo orgânico com a vida ativa, nasceu com Hegel e morreu em 48, verdade que morte anunciada, só que como realização prática dessublimadora do seu exercício em separado, pela esquerda hegeliana, jovem Marx incluído. A ser assim, uma Mimesis filosófica teria só um capítulo. Um capítulo que o Lebrun não poderia escrever, nem gostaria, aliás, pois a seu ver o discurso hegeliano definitivamente deixou de "figurar" ou "representar" o que quer que seja, por assim dizer entrando para o rol daqueles autores que o pobre Auerbach já não entende mais. Entre parênteses: no caso presente, com razão, pois creditava não especificamente a Hegel mas a todo o historicismo alemão a fundamentação estética do realismo literário ao cavar a profundidade histórica do presente, não sem paradoxo, pois o realismo literário alemão jamais conseguiria dar à luz algo que pudesse ombrear com o similar francês (mutatis mutandis, esse o único problema interessante no estudo da filosofia clássica alemã para quem a repassa do ângulo das vantagens e desvantagens da defasagem histórica implicada no capitalismo retardatário).

Voltando: ao passo que o nosso Lebrun por assim dizer cometia dois sobrepassos, primeiro ao pós-datar a dialética hegeliana tornando-a contemporânea, ainda que provisoriamente, como já lembrei, da literatura pós-realista e, segundo, ao desconhecer o efeito mimético da forma na arte que deixou de ser figurativa por razões intrínsecas e não por simples desfecho ideológico, porque enjoou de "representar".

ICC - Um pétard mouillé, então, toda a sua fantasia auerbachiana. O seu amigo Bento há de ficar desapontado pois, gostando ou não da Mimesis (e eu sei que ele gosta, e muito), bem que ele apreciaria um tropeço figurativo-realista do ex-aluno trânsfuga.

PA - Mais uma razão para confortá-lo com o seguinte palpite. O Habermas (de quem o nosso Bento não gosta nem um pouquinho, muito escoteiro e espírito de Natal para o seu temperamento anarco-boêmio parnasiano) é de opinião que aqueles dois conceitos de filosofia outrora reunidos por Hegel, o que nós estamos chamando de "profissional" e o outro, num certo sentido, "popular", na medida em que se refere àquilo que necessariamente in- 
teressa a toda gente, e para cujo eclipse ele não oferece a menor explicação fora da marcha institucional da modernização cultural, voltaram a se soldar nos anos vinte deste século, notadamente com o Ser e Tempo do Heidegger (de quem o Bento continua fã, principalmente deste livro, de cujo pragmatismo sui generis ele por certo deve reconhecer a presença no existencialismo ético do Wittgenstein que no momento anda lendo com muito fervor), na década seguinte com o Husserl da última fase, quando a seu ver a filosofia recupera de vez sua competência (epistemologicamente exercida no âmbito especializado da crítica da ciência por meio da reflexão transcendental, nossa conhecida, imagino) para fazer a diagnose de sua época. De minha parte, creio que já falei a respeito, acho que quem reler a interpretação husserliana da crise europeia dos anos 30 poderá até ficar sinceramente comovido, mas dificilmente deixará de reconhecer o fiasco daquela tentativa de restauração in extremis da Razão Teórica. Além do mais estou igualmente convencido de que o capitalismo mundializado, e por isso mesmo desregulado, dos dias de hoje está pregando uma outra peça análoga no programa habermasiano equivalente de restauração da Razão Prática (se não me engano, penso que o Lebrun chegou a fazer este tipo de comparação nos anos 70, numa época em que ele gostava muito de implicar com o Habermas, que ele julgava - acreditem se quiserem - marxista, e o amigo Bento também, ou apenas o suficiente para se divertir às custas dos amigos do pensamento alemão überhaupt - mas deixemos esse outro capítulo por enquanto de lado).

Pois assim seja: como até o título indica, Heidegger teria reunificado a filosofia, ressublimada como tribunal de última instância, juntando novamente Analítica da Verdade e Ontologia do Presente (para falar como o ou- tro). A ser assim, a nossa Mimesis filosófica não poderia prosseguir, ou melhor, recomeçar justamente a partir do último capítulo e para além do ponto final do livro? Será preciso dizer? Estou dando de barato que essa diagnose histórico-transcendental de época se repetiria de forma degradada: se a experiência vem definhando desde então, não seria a restauração de um gênero pretérito como a filosofia que a reergueria ao nível de sua antiga plenitude, aliás irrestaurável, quando muito "apresentável” quando se dispõe dos meios técnicos para transformar a alienação em processo de investigação; Heidegger e congêneres, pelo contrário, no seu melhor momento, isto é nos anos 20, estilizam o grau zero da nova alienação. Uma estilização desta ordem vem a ser por exemplo a mise en scène da heroica obstinação no ser-para-a-morte do indivíduo solitário de costas para a tagarelice da fala impessoal dos funcionários da humanidade. Vistas as coisas, no entanto, de outro ângulo - por que não? - o da filosofia reunificada no seu conceito como um caso de mescla estilística, de um lado o intemporal das estruturas existenciais que definem nossa Finitude, de outro a contingência angustiada do ser-no-mundo, etc., etc., vistas então desse ângulo, o que vem a ser uma tal estilização da existência, por isso mesmo batizada de "autêntica", senão a elevação da vida cotidiana (outra categoria heideggeriana) à dimensão trágica do nosso conhecido realismo sério? Um revival, enfim. E como tal, barateado, menos por falta de talento, é claro, que no seu gênero o filósofo em questão tinha de sobra, do que pela impossibilidade historicamente decretada pela liquidação da etapa anterior do capitalismo, propriamente "burguesa" (como querem alguns clássicos), de voltar a emparelhar o golpe de vista filosófico e a nova intransparência do mundo administrado da era imperialista 
stricto sensu (não podemos nos esquecer de que estamos no entreguerras, quando em princípio estaria brilhando esta mais do que inverossímil lucidez desfetichizante da consciência filosófica). Nestas condições, salta à vista o tamanho muito diminuído da nova série filosófica (nossa hipótese) correndo paralela e em contraponto aos capítulos subsequentes que Auerbach não escreveu, nem entenderia muito sua razão de ser.

Posso tentar dizer de outro modo a mesma coisa: embora rigorosamente contemporâneas, a "representação séria da realidade cotidiana na filosofia”, o que em última instância não deixa de ser o caso de uma hermenêutica da existência como a do Heidegger dos anos 20, por assim dizer, dado o desnível histórico assinalado, reduplica a alienação que sai engrandecida com a chancela da experiência-limite incontornável, enquanto na literatura (só para ficarmos no domínio de Auerbach) que deixou de ser "figurativa" justamente para não reduplicar essa mesmíssima fachada social reproduzida pelo jargão existencialista, deu-se em consequência uma reviravolta tal na noção de "representação" que lhe permitiria, ainda por um bom tempo (para alguns, pelo menos até Beckett), configurar o diagnóstico de época há muito tempo fora do alcance da filosofia: o movimento em falso do renascimento heideggeriano teve pelo menos o mérito de expor à luz do dia esse patético descompasso.

Ainda no âmbito dos falsos palpites, continuemos a confortar o amigo Bento, sartreano nos seus verdes anos. Reparemos então como a "transformação" da filosofia francesa operada por Sartre, aliviando-a (mas como quem bate uma carteira) da responsabilidade mais do que eminente pela fundamentação última (na verdade apenas mudou o registro desse direito à última palavra) para lançá-la no vasto mundo da "experiência" em competição com os demais "estilos" de decifração do "vivido", sendo afinal obviamente tributária da fenomenologia alemã, não deixa de ser igualmente uma representação séria da realidade cotidiana. Mescla estilística também aqui: tudo se passa no plano terrestre da vida de todos os dias porque a própria vida tornou-se de ponta a ponta metafísica, que por sua vez não é mais um aparato conceitual, mas a cifra do núcleo problematizante do existente, que atende agora pelo nome de "concreto", o nome mesmo da referida mescla auerbachiana. Não falta nem mesmo o sublime oculto na existência nua das coisas: rebatendo ainda nos anos 40 os ataques dos bem-pensantes contra o inegável gosto sartreano pelo asqueroso, Merleau-Ponty defendeu a novíssima filosofia evocando um sentimento inédito, segundo ele a invenção do nosso tempo, que batizou de petit sublime, procurado sem eloquência e sem ilusões. Pois não se dá neste registro misturado a revelação nauseante da contingência? Reforçando essa curiosa convergência entre "realismo sério" e seu afunilamento na direção da "descrição" fenomenológica de essências ou significações vividas, basta recuar no tempo e observar um pouco (de preferência num vertiginoso relance) Kierkegaard inventando uma nova vida interior filosófica (isto é, elevada), cujo incógnito o selo irônico dos pseudônimos protege de qualquer interpretação impertinente que lhe possa dirigir o curso material do mundo, mas reparando ao mesmo tempo no decisionismo bíblico (o sacrifício de Isaac, por exemplo) que não por acaso enquadra num pathos muito característico a travessia terrena mais adiante denominada Existência.

MEC - My Good Lord! Era só o que me faltava: um Auerbach existencialista! 
ICC - É nisso que dá bifurcar tanto. Mas você está mesmo a fim de encarar esse despropósito?

CR - Também acho. Se você for perguntar na Alemanha, por exemplo, a favor ou contra, todo mundo vai dizer que o Auerbach, romanista, filólogo, era um perfeito humanista no velho estilo da erudição alemã de antes da Primeira Guerra; sem dúvida um liberal discreto durante a República de Weimar, que jamais enturmaria com os Jovens Conservadores da laia dos Jünger, Heidegger e cia. bela. E tem mais - corrijam-me se eu estiver enganada na minha impressão. Enquanto o Paulo ia se enterrando nessa digressão em má hora encomendada, eu pensava: não é que esse filólogo perdido no mundo moderno, sem entender o desfecho que ele mesmo historiou, é muito parecido com o narrador do Dr. Fausto do Thomas Mann? Existencialista, o assustadiço professor Serenus Zeitblom, desorientado como toda a Alemanha cultivada diante das forças que empurraram o seu genial amigo na direção da catástrofe?

PA - Antes de mais nada: "existencialismo”, sobretudo na sua versão original, isto é, alemã, não significa clarividência quanto ao presente histórico. Muito pelo contrário, investe no encobrimento pela formalização dos sintomas do enregelamento social, estes sim, escolhidos a dedo com vistas ao correspondente destaque. Segundo ponto: nunca me passou pela cabeça um Auerbach existencialista. O que me ocorreu foi justamente desenvolver um pouquinho a impressão inversa, a saber: primeiro, o caráter cristão lato sensu do existencialismo filosófico, muito visível na sacralização do existente, provido in extremis de uma aura metafísica, evidentemente bastarda num mundo inteiramente socializado pelo capital. Onde a vida imediata plena de sentido? A seguir, sugerir que a junção do metafísico e da vida cotidiana traduzia à perfeição, por um lado, a mescla auerbachiana responsável pelo realismo problematizante e sua sondagem em profundidade do decurso das coisas terrenas, por outro (graças à observação referida pelo Habermas), mimetizava à distância, e por isso mesmo de modo irrecuperavelmente irrisório, a antiga visada totalizante da filosofia imediatamente antes da Queda. E só. Portanto, uma convergência por um lado só, com a qual o Auerbach não teria absolutamente nada a ver. Acontece que me caiu nas mãos há questão de um ano, acho que por sugestão do Modesto Carone, leitor contumaz de Auerbach, um estudo muito curioso de Hans Gumbrecht sobre o cotidiano segundo Auerbach. E aí a coisa virou. Aliás acabei de pastichar-lhe o título, "pathos da travessia terrena", frase conclusiva do artigo de Auerbach sobre Proust. Virou para os lados do nosso filólogo que parece ter cogitado num certo momento denominar o seu realismo problematizante (por oposição ao meramente moralista) "realismo existencial", mas acabou desistindo por julgar a expressão demasiado contemporânea para designar fenômenos que remontavam a um passado relativamente remoto. De qualquer modo (no que nos interessa mais de perto), a pré-história oitocentista da invenção fenomenológico-existencial de um cotidiano sobrecarregado de segundas intenções metafísicas. Ora, sem no entanto empurrar de modo algum o pacato e muito cumpridor professor de filologia românica Erich Auerbach para o lado sombrio da Revolução Conservadora em curso na Alemanha intelectual em busca de segurança e "concretude" em meio à irrealidade e falta de substância da vida contemporânea sob a égide da malfadada civilização material, o Autor do estudo em questão alinha o 
nosso Serenus Zeitblom, bem lembrado pela Christine, e sua fascinação com a realidade cotidiana, àqueles ideólogos à cata de compensações "concretas" para o sentimento de perda e declínio que a abstração da vida moderna lhes sugeria. Como alguma coisa do tipo verdade objetiva, ou qualquer coisa do gênero com jeito de instância orientadora substantiva, estava em falta e para sempre, todos eles se voltavam para a âncora da "existência autêntica" e suas inumeráveis estilizações da "vida cotidiana ordinária”, que poderia chegar até ao mais extremo dandismo. Sendo estético o contraste entre a autenticidade cotidiana e o anonimato da banalidade comum, muitos naquela quadra, entre eles Auerbach, sempre segundo o nosso Autor, se voltaram para as questões de estilo e forma enquanto penhor da autenticidade de um destino individual cujo caráter emerge da esfera inevitavelmente trágica da vida cotidiana, a partir da qual se sentiam obrigados a inventar a própria identidade enquanto forma. (Lembro de passagem que esta perspectiva que conferia, nesses termos, valor existencial à dimensão da forma, não terá sido estranha ao ensaísmo, enquanto gênero extremo de equilíbrio precário num mundo sem alma, numa geração intelectual como a de Simmel e o primeiro Lukács.)

Uma outra observação também vai nessa direção. Já não me lembro mais quem, possivelmente um bom especialista em Auerbach que li faz tempo, comentando os escritos dele sobre Dante, notou que a ideia central de Mimesis, justamente a propósito do realismo com que na Comédia a sentença divina completa e atualiza definitivamente o caráter outrora terreno dos seus personagens, tem a ver com uma decisão, com a escolha e conquista de uma forma que nos permita ultrapassar a mediania sem caráter dos nossos semelhantes (em banalidade - coisa mortal). Enfim, um outro circunlóquio a nos trazer de volta à famigerada "autenticidade". Mas o que de fato gostei de reencontrar no artigo em questão, sobretudo nessa inesperada aliança com a fraseologia existencial, foi exatamente o lado Serenus Zeitblom do nosso personagem, porém realçado por um outro prisma, como disse: é que, segundo o tal autor, o que a rigor teria fascinado Auerbach nas obras literárias eram os rituais de normalidade que envolviam a vida cotidiana levada a sério. Dito isso, a descoberta verdadeiramente interessante, a lembrança de que o tópico literário da cotidianidade problematizante, era da mesma índole, existencial no caso, que a decisão de Auerbach de optar pela normalidade da existência enquanto funcionário civil de uma administração que ele continuou acatando, mesmo depois de expurgado pelas autoridades nazistas. A palavra "compostura" resume à perfeição os desdobramentos tanto burocráticos quanto filológicos desse existencialismo prático - se nosso Autor interpreta bem o seu material biográfico. O preço pago foi evidentemente a estreiteza da visão política pois, segundo Gumbrecht, deve ter sido para não perder a compostura que muitos intelectuais judeus se submeteram, numa estranha forma de tolerância, aos rituais de humilhação e tortura com que os perseguia o Terceiro Reich. Certamente algo da redescoberta do sermo humilis como base terrestre do realismo trágico da vida cotidiana, por isso mesmo mantida à distância na sua trivialidade inautêntica, terá a ver com esse ideal de circunspecção, modéstia e correção de maneiras altamente estilizada que nosso autor batizou de "compostura", dando a entender que a procura estoica de serenidade por meio da forma, em todas as suas variantes, podia muito bem se encarnar no referido zelo administrativo. 
Tudo isso pode ser verdade ou não, no caso particular de Auerbach. Pouco importa. O fato é que ao interpretar a mescla estilística nos termos de um possível realismo existencial (perfeitamente verossímil enquanto construção ideológica datada), nosso autor revelou sem querer o fundo falso muito nosso conhecido da presumida restauração da filosofia na posse de suas duas dimensões originais discernidas e apartadas por Kant no limiar da assim chamada modernidade. A reintrodução do metafísico (outro nome escuso, e denegrido pelo positivismo, para totalidade) na vida de todos os dias, redimindo-a de sua condição mesquinha (façanha que no Brasil estaria ao alcance de qualquer bacharel, dada a altitude condoreira com que costuma sobrevoar o país real), corresponde ponto por ponto à divisão do trabalho da qual acho que já falei um pouco: de um lado a velha teoria do conhecimento como análise lógica da linguagem, do outro o campo ilimitado e arbitrário das avaliações selvagens na origem da atribuição de sentido a um destino individual, demarcados e solidários. Enfim, positividade bem calculada e estremecimentos metafísicos. Mas não é isto a compostura? De um lado o rito racionalizado da administração sem falha de coisas e pessoas, de outro o pathos contido inerente ao sentimento trágico da travessia terrena. Noutras palavras, o existencialismo não é o privilégio de uma sensibilidade de elite, pois se encontra ao alcance de qualquer servidor, mas não de uma burocracia qualquer. Aqui a cor local na qual já esbarramos a propósito da invenção alemã do historicismo, sem a qual, segundo Auerbach, o moderno realismo literário seria impensável, assim como a inexistência de uma linhagem realista significativa na literatura alemã. Ora, se eu estivesse mais adiantado na nossa conversa, lem- braria ato contínuo que esse ideal de compostura como estilização da existência (e deveria ter notado, fechando o ciclo, que o formalismo do serviço burocrático simplesmente sanciona a abstração da vida moderna, cuja falta de substância justamente está na origem da mitologia compensatória "existencial") é parente muito próximo e contemporâneo do dilema dos personagens da primeira fase de Thomas Mann, divididos entre o decoro burguês puramente ritualizado e a desagregação fin de siècle dos sentimentos, alternativas na verdade implicadas uma na outra por força da decomposição do antigo patriciado cultivado alemão. Pelo menos foi assim que Lukács estudou os burgueses extraviados de Thomas Mann, e eu, é claro, atrás dele, nessa reconstituição da procura alemã de um certo burguês a rigor introuvable.

MEC - Mas no que lhe concernia essa ideia fixa alemã, se faz favor? Pelo que me consta, você nem germanista é, nunca foi visto no Goethe nem na Alemanha, e quando escreve a respeito cita tudo de segunda mão e em tradução. Pelo menos é o que corre por aí, eu mesma não sei de nada, nem estou interessada, muito menos em países fracos de Cultural Studies.

PA - Pois fique você sabendo que o que corre por aí é a pura expressão da verdade. Seja dito em minha defesa que se nunca procurei levar ninguém na conversa, tampouco esclareci o que quer que seja, reconheço. Ou melhor, alertei a Christine aqui presente logo de saída, se vocês ainda estão lembradas de que nosso assunto ainda é o tal livro sobre o $A B C$ da Miséria Alemã. Aliás o título é sugestão dela mesma, e pode ser encontrado no prólogo do Preceptor de Lenz na adaptação de Brecht, que a nossa amiga ha- 
via acabado de traduzir. E a capa também: já que se trata de um falso germanista, eu não posso deixar de informar a respeito o leitor que está comprando gato por lebre, daí a capa.

CR - Plenamente justificada: quem já publicou numa falsa Gallimard um livro (errado, segundo os protagonistas) sobre um falso Departamento Francês de Filosofia, pode perfeitamente publicar um falso livro de germanística numa falsa Suhrkamp.

MEC - Você não tem medo de ser processado?

ICC - Mas o país também é uma armação!!!

PA - Pois nem disso eu tinha notícia enquanto escrevia o meu hegelzinho sob os olhos da colônia uspiana de Paris.

ICC - Ora vejam! Não é que o nosso memorando encontrou sozinho o caminho de volta?

MEC - De volta para onde, se até agora ele não foi para lugar nenhum?

CR - Erziehung à brasileira deve ser assim, imagino: aprendem sem sair do lugar.

ICC - Vamos então voltar ao rolo original: por ocasião da descoberta do Brasil, estava o memorando abancado em seu studio de ultramar, fabricando um doutoramento sobre assunto remoto em chave idem. Ou vice-versa, que neste caso deve dar na mesma.
CR - Não vejo nada de mais, em se tratando de um país achado como o Brasil. Quem foi achado vive se perdendo, não é mesmo?

PA - É. Bem que a Marlyse poderia prever casos individuais e fora de tempo na tipologia dela. Mas nem esse seria o meu caso, pois nunca me passaria pela cabeça que seria preciso descobrir o Brasil. Se o meu negócio era filosofia, embora não levasse jeito, então não existia Brasil nenhum, minha terra natal estaria no outro mundo.

MEC - O cavalheiro poderia fazer a gentileza de se explicar melhor?

PA - Estava divagando, à procura de um enquadramento nobre para o meu caso. Mas não se aplica, como acabei de informar. Pelo seguinte: o Brasil de fato é um objet trouvé, uma trouvaille do capital comercial (uma vasta operação mercadológica colocou o açúcar de cana como o principal item na pauta do comércio internacional) que virou com toda razão piada dadaísta (e como já foi observado, estou repetindo para variar, até hoje não há intelectual brasileiro que vez por outra, ou mesmo em permanência, não viva em estado de paródia). Sendo então um país achado, como lembrou a Christine a meu favor, em vão, porém, pois eu estava na contramão da mania compensatória que passo a referir (sempre na intenção dos mais jovens), redescobri-lo a cada reviravolta da nossa conjuntura ideológica tornou-se uma espécie de compulsão nacional e por isso mesmo objeto do piadismo modernista, piadismo ambíguo como se sabe, já que o Brasil escondido a ser descoberto não era só natureza sublimada, mas sobretudo primitivismo recalcado. O correspondente destape implicava, portanto, a um 
tempo atualização e reconciliação com a paisagem incivilizada. Assim, quando estudava na Faculdade para professor de filosofia aprendendo a fazer dissertação com maiúscula, não tinha a menor ideia (e como poderia?) de que era neto ou bisneto de um ciclo decisivo daquele mesmo ímpeto descobridor, transfigurado agora na produtiva ilusão ilustrada de sempre, sob cujo imperativo compraríamos livros e contrataríamos professores no estrangeiro, subvencionaríamos as elites e assimilaríamos finas culturas, enfim, cuidaríamos do Estado Técnico, na enumeração do poeta no Brejo das Almas. Expedientes infalíveis num país de eternos bolsistas como o nosso, como gosta de lembrar um dos meus mentores. Nessa parte do meu devaneio nobilitador é que entra a Marlyse Meyer. Relembro porque me foi solicitado, já que não me enquadro na fórmula, por absoluta insciência, uma vez que, repito, estudava para ser um aristocrata do nada, como dizia Paulo Emílio quando pensava nos nossos críticos de cinema às voltas com um paideuma de filmes estrangeiros cujos longínquos diretores sequer podiam imaginar (e reagir de acordo) a existência de glosas admirativas e prolixas cuja única razão de ser era demonstrar preferências de escol e enturmar com os unhappy few locais. Pois então: diante dessa síndrome familiar, nossa amiga Marlyse Meyer observou certa vez que esse tema recorrente das descobertas do Brasil costuma tomar o aspecto obsessivo de um Eterno Retorno, passando ato contínuo ao inventário das sucessivas apropriações letradas do Novo Mundo, desde os descobrimentos retóricos dos primeiros séculos até os desdobramentos recentes das redescobertas por assim dizer não oficiais, aparentemente nos antípodas dos antigos deslumbramentos aliciadores, com destaque é claro para a explosão modernista e seus deflagradores vindo de fora, para variar.

\section{MEC - E então?}

PA - Então nada. Já disse que estava procurando em voz alta uma muleta enobrecedora, à toa, como se está vendo, pois àquela altura da minha formação (latíssimo sensu) nenhuma mosca descobridora me mordera. Então tudo, também. É que nunca seria demais relembrar que Formação, agora na acepção brasileira mais forte do termo, e Descoberta do Brasil se cruzam igualmente sob o signo de uma experiência negativa também muito peculiar, e com a qual, já posso adiantar, tem tudo a ver aquela outra, evocada numa rodada anterior, na origem da compulsão nacional da reflexão metafilosófica em torno da filosofia que há de vir mas ainda não nasceu, espécie de caricatura involuntária daqueles recomeços radicais que impulsionavam a fenomenologia husserliana ao redor do mesmo marco zero introuvable. Pois o Eterno Retorno muito sugestivo da fórmula da Marlyse Meyer encerra um ponto nevrálgico de nossos complexos coloniais, mais exatamente ele evoca com precisão uma certa ideia muito familiar de repetição sem progresso, de eterno recomeço da capo (estou reprisando sem querer a expressão de há pouco), numa palavra, o vício de origem de nossas "formações" truncadas, linhas evolutivas precocemente atropeladas por um boato novidadeiro qualquer, enfim um país movido a espasmos (da economia de fôlego curto aos estilos artísticos idem), da vida mental aos arrancos como vimos, essa a constelação em que brilha como uma estrela a "obsessão" do nosso amigo Giannotti, que trocou a inegável "obra" passada pela alta seletividade ética implicada pelo Eterno Retorno do Mesmo. Pensando bem, não é que eu me encaixo na moldura? Mesmo não estando previstos casos de inépcia individual, a inconsciência 
em que vivia não era efeito de uma decapitação de mesma ordem, uma vez que o enxerto filosófico estava obrigado, para vingar, a apagar a experiência local havida em nome da ascese metodológica exigida? Pela mesmíssima amputação, eu não sabia que devia tudo à cultura filosófica uspiana cuja formação enfim se completara e por isso mesmo me extraviara por uma pista inexistente. Teria assim que recomeçar do zero, sozinho e fora de época (o último ciclo de redescoberta coletiva do Brasil fazia tempo ficara para trás). E quando falo sozinho, estou pensando no meu métier. (Há no entanto uma exceção notável, à qual uma hora dessas precisarei me referir.) Feita a ressalva, isto é, localizado o ponto onde eu patinava imaginando progredir à sombra da boa consciência profissional, não acho demais observar por outro ângulo a pertinência estrutural da experiência negativa a que deu nome o título certeiro de Marlyse, um Eterno Retorno. Entre parênteses: sublinho o traço negativo que realça nossa peculiaridade (está claro que nunca isento das respectivas sublimações positivas), pois no contexto europeu oitocentista de origem, e depois em sua retomada contemporânea, em particular pela Ideologia Francesa, o mau infinito dessa Repetição do Mesmo é visto como um bom sinal, entre outras coisas por supostamente reinverter a cadeia maléfica que une História e Ressentimento: preciso dizer qual a data histórica dessa fantasmagoria? Aliás, se nós pensarmos nos esquemas machadianos do Roberto Schwarz, onde melhor transparece a referida dimensão estrutural, seria até o caso de imaginar sem muito erro, uma vez demonstrado que nossas anomalias podem ser vistas não como mero desvio, mas implicação inerente à reprodução da normalidade burguesa mundial, que a dita figura local do Retorno alguma coisa de essencial há de iluminar no seu homólogo europeu, princípio euforizante da fraseologia afirmativa da Vida e Cia. Estou pensando, como era de presumir, nos altos e baixos do Narrador machadiano da segunda fase, se é fato, como estou convencido, que o mau infinito, o que nos definiria, também se dá a conhecer na monótona alternância sem peripécia entre animação e fastio, sofreguidão e inapetência, etc., ao seu modo um Eterno Retorno alimentado pela matriz prática de nossa Dualidade constitutiva, como sabemos, mecanismo armado pela persistência do Antigo Regime colonial, não como resíduo mas reminiscência funcional, na atualidade do capitalismo moderno.

E já que estamos indo por esse caminho, que não é de simples variação terminológica, acho possível acrescentar que estamos ingressando noutro ciclo de Descoberta do Brasil sob o mesmíssimo signo, agora pateticamente nefasto, do Eterno Retorno, se com ele quisermos denominar o tema recorrente da modernização que um dia há de se completar. A saber: a descoberta da construção nacional definitivamente interrompida, para levar às últimas consequências o capítulo conclusivo da obra de Celso Furtado, cujo acerto deverá arrastá-lo para o lado dos perdedores. Descoberta de um país que está deixando de existir sem nunca ter sido para valer, descoberta portanto da verdadeira parte que nos tocou no processo mundial da modernização capitalista em fim de linha, revelação de que o desastre contemporâneo é a perpetuação da modernização que faz tempo já nos alcançou e é isso aí mesmo que estamos vendo, abortou ao se consumar. Daí a nova era da Repetição que estamos inaugurando (sim, sim, etc.). Para além da fachada apologética meramente afirmativa, o mais simples sobrevoo da desintegração social em curso - desintegração é dizer demais, pois nunca 
houve real incorporação da legião colonial dos esbulhados, que nem mesmo chegaram a desfrutar do privilégio de ver sua força de trabalho regularmente explorada - deixaria entrever uma lógica social em que os conflitos de toda ordem, dos fundamentais aos mais periféricos, se repetem sem que nada se aprofunde e desenvolva, mesmo na ordem do negativo e da oposição em marcha. Ora, não espanta que o mesmo autor que matou a charada Machado de Assis, tirante é claro a parte devida ao olho clínico altamente apurado, uma vez instruído pelo andamento regressivo da mundialização do capital, e justamente pouco aprenderia a respeito (como parece ter sucedido à maioria de seus antigos companheiros do Seminário Marx) se já não tivesse o golpe de vista escolado pela lição de Machado acerca das virtualidades retrógradas preponderantes na configuração brasileira da modernização capitalista, como se nalgum momento entre a primeira e a segunda fase nosso maior escritor tivesse como que antevisto, na marcha recalcitrante de nossas elites para o mundo moderno, como que o pressentimento, ou que for, de que a convergência entre progresso e sociedade brasileira em formação era mesmo um mito e que assim sendo nosso futuro tinha ficado no passado. Pois então já não surpreende tanto, como eu estava dizendo, que o Roberto Schwarz tenha sido o primeiro entre os nossos marxistas ocidentais, e até onde eu sei o único, sobretudo nos seus últimos escritos, todos eles posteriores à leitura de Kurz (e agora fica bem mais fácil reparar na convergência entre o Brasil rifado na sua passagem para o moderno, literariamente construído por Machado, e o diagnóstico do teórico alemão acerca do colapso de nossa modernização, colapso estrutural e que, ao progredir da periferia para o centro, nos devolve pelo menos à vanguarda da desintegração, como já notou o mesmo Roberto, sem dúvida pensando na atualidade estética das premonições machadianas, atuais ontem e hoje), o primeiro, portanto, a registrar, e glosar em termos que podemos traduzir para o vocabulário da Repetição do Mesmo (e olhem que não estou só brincando ao assinalar esse tipo de verificação empírica brutalista de elocuções metafísicas remotas), que, liquidados em escala mundial, Nacional-desenvolvimentismo e Economia de Comando, não se abria para o país (em adiantado estado de desmanche) uma nova era de Desenvolvimento (enquanto reprodução coerente da sociedade segundo padrões modernos fixados pela matriz metropolitana histórica), mas de Repetição (a modernização sem aspas que nos coube, que absolutamente não leva a parte alguma, mantidos os polos alternos Mercado e Estado).

Repetição do Mesmo, é claro. Em todos os níveis. Desde o subsolo mais infernal da abstração real: pois o que faz o diabo do Sujeito automático, como Marx costumava definir o Capital, senão repetir o mesmo movimento de valorização do valor como um fim em si mesmo? (Lembro de passagem que na primeira metade dos anos 70 alguns ideólogos parisienses farejaram alguma coisa da afinidade entre Capital e Eterno Retorno, com o sinal trocado, é óbvio, e uma curiosa variante deles chegou a notar que Acumulação não excluía Repetição e que ambas podiam ser encaradas do ângulo especulativo do Infinito, ora mau, ora verdadeiro). Até o plano mais barulhento do realejo ideológico: aqui voltamos ao Roberto Schwarz pois devemos a ele as primeiras observações bem organizadas acerca da reaparição de um velho lugar comum da fraseologia brasileira, o do atraso nacional e sua patologia como uma diferença a tirar em relação aos países desenvolvidos, no que ficava pressuposto que o moderno se resumia a um 
conjunto de normas a serem progressivamente observadas - como sabemos, sua intuição original do Brasil, que reencontrou funcionando na fala caprichosa do narrador machadiano, andava precisamente na contramão desse mito dos tempos do Brasil-identidade, hoje renovado pelos ideólogos da modernidade incompleta.

MEC - Que mito, mais exatamente?

PA - O mito de que estava falando ainda há pouco, orientado pela bússola schwarziana é evidente, a velha fantasia de que a Nação, erradicadas as raízes coloniais, responsáveis em última instância por tudo aquilo que o establishment intelectual de turno considera arcaico (ontem podia ser Canudos, hoje os parasitas da Previdência), fatalmente reencontraria seu futuro de civilização e progresso. Hermenêuticas amalucadas à parte, podemos pensar nalguma coisa assim, da ordem do mito de Sísifo. Fomos aliás embalados mais precisamente pela promessa da sua resolução. Basta percorrer de relance o panorama traçado pelo Roberto ultimamente e verificar se não se confirma a impressão do Eterno Retorno, a face oculta dos recorrentes surtos de redescobrimento do Brasil: assim como já trocamos escravismo por formas de trabalho mais ou menos livres, uma economia primário-exportadora por outra industrial, embora dependente, nada impede que nossas elites se autorreformem e evoluam do clientelismo para a conduta racional, do coronelismo para a cidadania, da corrupção para a probidade, do protecionismo para a exposição à concorrência internacional e assim por diante. A formação nacional é de fato vista como uma tarefa inconclusa de apropriação da normalidade burguesa encarnada pelos países que nos servem de modelo, agora, depois da Queda, como um trabalho de Sísifo empulhado pela ladainha da modernidade incompleta: sim, fomos atropelados pela Terceira Revolução Industrial, mas os novos padrões tecnológicos podem ser alcançados mediante um ajuste, etc., etc. E assim, de eufemismo em eufemismo, apenas um esforço suplementar nos separaria do concerto das nações evoluídas, e por aí afora desde a Independência. Deu no que deu, como sabemos: quer dizer, a modernização já se completou faz tempo (não nascemos modernos?), ela é isso mesmo que está aí, promessa não cumprida realmente existente (mas não é isso mesmo o capitalismo?), não há nada por realizar, ou por outra, ela é a repetição dessa promessa sem futuro, repetição prática e ideológica (veja-se agora a fraseologia em língua de instituição multilateral acerca da nossa transição dual, transição ad infinitum como é fácil adivinhar, com os programas de estabilização pela estabilização, mais o lero lero de praxe quanto à retomada do crescimento que por certo virá, até o próximo tombo e assim sucessivamente).

Extrapolação? Acho sinceramente que não. Penso até que sem nenhum arbítrio esse destino está escrito na compulsão à repetição que anima o narrador machadiano decifrado pelo Roberto, como já disse. E tenho uma contraprova do cumprimento dessas profecias ou premonições por fidelidade estrutural à matriz prática desse Eterno Retorno na acepção brasileira do termo, colhida na sequência mesma dos trabalhos do nosso Crítico. Estou pensando, por exemplo, no que ele viu muito bem no romance de Chico Buarque, Estorvo, mais exatamente a fuga do narrador, fuga que não o leva a parte alguma, pelo contrário, pois ele acaba voltando sempre aos mesmos lugares, reincidências sem fim à vista que, segundo Roberto, funcionam como uma metáfora do Brasil contemporâneo, 
só que agora a mitologia da modernidade por completar se apresenta invertida como uma disposição absurda (popular? de um veterano meia-oito?) de continuar igual, só que em condições reconhecidamente impossíveis (a verdadeira modernidade realmente existente). E tudo isso visto em agosto de 91, nem sombra de Kurz no horizonte, tal a força da configuração estética da experiência em curso quando repassada por um crítico à sua altura.

Parênteses. Nem me perguntem por onde andava a filosofia àquela altura. Se puder responder por mim, à revelia de meus confrades, sinceramente desolados, lembraria que estava redigindo a minha plaquete sobre o próprio e seu mestre Antonio Candido, sem ter ideia de que a Dualidade que andava virando e revirando estava se reapresentando na forma dessas reincidências.

Completo o raciocínio (por assim dizer) evocando um elo intermediário entre o narrador volúvel e a deambulação circular de um narrador desta vez absolutamente moderno (e sua contrapartida popular, a legião dos sujeitos monetários sem dinheiro, para falar como o citado teórico alemão que está nos servindo de baliza para uma periodização que não é meramente local, em que pese a descoberta a bem dizer casual do dito alemão): é que acabei de me lembrar que num ensaio ainda inédito Dona Gilda de Mello e Souza descreve a certa altura a movimentação alucinante de Macunaíma, correndo sem parar de um lado para outro. Ora, sabemos todos que ele afinal também não vai a parte alguma, salvo o céu imaginário da transfiguração artística. Desse Eterno Retorno do Mesmo ao mundo nirvanizado do Turista Aprendiz era só um passo. (Acrescento in extremis que na Ideologia Alemã pós-48 um não vinha sem o outro, mesmo na forma de um par antitético.) Mas chega de divagações.
ICC - Aliás perigosas. Me desculpe o mau jeito, mas você usou e abusou do direito de fazer paralelos e analogias do emprego inocente da fórmula sem dúvida sobrecarregada de sentido - Eterno Retorno - a propósito das várias Descobertas do Brasil, desde a miragem inaugural da Visão do Paraíso até o Cinema Novo, passando pela invenção parisiense da civilização Pau-Brasil, etc., até a torção meio brusca que introduz o mote nietzscheano, ou melhor, o seu miolo referido muito obliquamente como se fosse a coisa mais sabida do mundo, entre as glosas possíveis da mitologia nacional da modernidade incompleta. E isto sem falar no flerte meio leviano, mas sempre sugerindo que pode virar coisa séria de uma hora para outra, como em todo flerte que se preze, com a conceituação hegeliana, abstrusa até segunda ordem, do Infinito e suas variantes materialistas apenas insinuadas. Completando o imbroglio, alusões explícitas, porém herméticas, à Ideologia Alemã, revista no entanto por um prisma comparatista francês, se é que entendi bem uma ou duas palavras aí pelo meio. Francamente, se o propósito é esclarecer, você só confunde!

MEC - E vice-versa, involuntariamente.

CR - E pensar que todo esse vai-e-vem não deveria ser mais que uma hipotética falsa moldura para enquadrar um personagem menor, de costas para o Brasil por mera deformação profissional...

PA - Mas se eu me explicar sem essa nem mais aquela, acaba a conversa.

MEC - Não seria má ideia. Mas concedo que espichá-la, além de cumprir a regra de polidez que condena ao en- 
tretien infini para não deixar a conversa morrer, é decorrência natural desse tal de pensar em brasileiro que não consta de nenhuma bibliografia consolidada. Supondo que de fato seja assim, admito que seja permitido inventar quase tudo na hora.

ICC - Ihh! Pelo visto, a balda é contagiosa. Mais aviso aos navegantes: a Professora Maria Elisa já se prepara para desembestar.

MEC - How kind of you, my dear!

ICC - Não sem antes - a moda pega mesmo - soltar um título chave de um dos precursores da Ideologia Francesa, Maurice Blanchot (com evidente efeito de eco na terminologia subsequente dos différand, mésentente, etc., do referido ideário parisiense da Diferença). Mas essa eu vou deixar barato.

PA - Eu também, se não houver objeções.

MEC-Muito bem, se é assim, o memorando poderia fazer a gentileza de nos informar que ventos empurraram a caravela do novo audaz navegante rumo às costas brasileiras.

ICC - Pela música, vem segredo de Polichinelo.

PA - Exatamente. Ventos schwarzianos.

MEC - Para variar.

ICC - E também para variar, seu ex-professor Bento Prado na certa preferiria falar de calmaria em vez de vento.
Brasileiro que descobre o Brasil não sai do lugar, fica na mesma. É ou não é?

CR - Então uma alma inocente como a de Hans Castorp, disputada palmo a palmo por uma espécie de Settembrini de Almeida Prado?

MEC - Mas o Naphta seria a sereia ou o desconfiado?

PA - Tanto faz. O nosso Hans Castorp, de qualquer modo, era muito duro de cabeça. Primeiro teste: no comecinho de 1970, o Roberto Schwarz me passou o ensaio dele, recém-concluído, sobre cultura e política no Brasil dos primeiros anos depois do golpe. Sem favor nenhum, um dos maiores ensaios da minha geração. Impossível não gostar, mas literalmente não entendi nada. Até hoje enrubesço, mesmo achando graça: e se de fato continuasse a ser como era naquele mês de fevereiro ou março de 70? Sinceramente, dá vertigem. Mas isso, hoje, 25 anos depois. Naquele momento, nem tanto, tal a couraça do meu analfabetismo filosófico. Simplesmente não entendera 64, muito menos o que viera antes, não obstante ter participado do Movimento Estudantil. Não sabia nada igualmente do que a ciência social uspiana vinha dizendo do Brasil havia pelo menos dez anos. Na cabeça, o conselho do Bento, dado na primeira hora: fuja daquela prosa cinzenta e da falta de imaginação dos que a perpetram. Seminário Marx? Vaga notícia, também na versão Bento: tudo parecia muito pitoresco, mas nada parecia servir, a não ser para aquelas teses ilegíveis dos sociólogos - eles não falam das coisas, insistia meu mentor, é só dinamismo, padrão disso ou daquilo, fração de classe pra lá e pra cá. O Ruy Fausto, cuja casa comecei a frequentar com assiduidade a partir de 
1967 e 68 (depois todo mundo levantou voo), também não se esforçava muito para me desasnar. Pelo contrário, estimulava meus estudos de Lógica. Me lembro de ter visto na mesa dele o número especial da Temps Modernes sobre o Brasil: preferia comentar um artigo teórico do Poulantzas. Nada contra, mas precisava explicar ao aluno que uma coisa não poderia andar sem a outra.

MEC - Estou vendo que o professor andou exagerando um pouco no capítulo circunstâncias atenuantes, porque estruturais, para o fato de um jovem estudante e logo professor uspiano de filosofia nada saber do que se passava à sua volta no país e no mundo. Pelo visto, os seus mestres sabiam muito bem das coisas. Seu esqueminha sai meio baleado do entrevero.

PA - Nunca disse o contrário. Sabiam muito mais do que eu poderia sequer imaginar. Mas era tudo capacidade ociosa: já disse e insisto que nada vindo da filosofia poderia pôr em movimento aquela espécie de senso comum sociológico da Faculdade. E olhe que estou falando do mais politizado dos meus professores, o Ruy Fausto, quem primeiro me fez ler o Trotsky do Isaac Deutscher, por exemplo, pois foi ele também um dos principais animadores da revista Teoria e Prática, que circulou exatamente no período coberto pelo ensaio do Roberto. Uma quadra decisiva para mim, repito, passou em branco, inteiramente ofuscado pela momentosa iniciação nos arcanos da filosofia franco-uspiana. Um exemplo do que eu estava dizendo: não é que o meu professor Ruy Fausto, depois de uma parceria promissora e muito divertida com o Roberto (um artigo sobre os escritos políticos de Oliveiros S. Ferreira), comenta no número seguinte A revolução brasileira do Caio Prado
Jr.? Meu esquema estaria gravemente comprometido pelo episódio se o amigo Ruy não tivesse se servido do livro, verdade que com inteiro conhecimento de causa, como um trampolim entre outros para a formulação de teoremas filosóficos com vistas a uma futura Lógica Dialética que já por aqueles tempos andava ruminando.

O segundo teste veio alguns meses depois, creio que outubro de 1970: num seminário na casa do Bento, o Roberto iria nos expor o que andava pensando do Machado, mas ainda não pusera no papel. Antes de apresentar o seu esquema geral, teve a inspiração de começar por uma leitura do capítulo do verdadeiro Cotrim no Brás Cubas. Foi uma revelação. Pois uma leitura com as ênfases no devido lugar era o quanto bastava para todo mundo rolar de rir e a sessão terminar em clima de chanchada. Veio depois a explicação, e o pouco que consegui acompanhar, compreendia pela metade. Como também um ano antes, lendo o decalque do Alienista, a crise de valores em Itaguahy que o Roberto convertera num misto de peça do Arena e filme da Atlântida, nunca sabia se estava rindo ou deixando de rir na hora certa.

MEC - De fato, uma cabeça dura de abrir. Estou começando a achar que se trata mesmo de um caso pessoal, sobre cujo fundamento empírico muito específico seria arriscado demais buscar qualquer indução sociológica consistente.

PA - Neste ponto preciso, tendo a concordar com o Bento acerca do alcance diminuto da explicação sociológica.

MEC - Mas não dizem por aí que você acabou na sociologia racional das ideias? 
ICC - Pois ainda prefiro sociologia dedutiva às ciências sociais ditas de observação, geradas pela irrecusável desestruturação dos tais mapas cognitivos alegados pelos ajustados ao novo padrão-de-inserção-internacional da vida intelectual brasileira, se é que esta última expressão ainda faz sentido no mundo acadêmico movido a reforço de percepções circularmente induzidas pela grade fraseológica dos mesmíssimos supracitados mapas de reconversão das operações mentais dos agentes técnicos... Aaarrgh! Vocês aguentam mais? Então lá vai: dos agentes técnicos cuja arcaica cultura oposicionista foi metabolizada, durante a frustrante travessia dos anos 80, em cultura governista, transição amplamente consagrada nos livros-texto da literatura relevante, onde não faltam farta amostragem de correlações encontráveis em toda parte entre episódios de abertura e aumento sustentado de produtividade cognitiva...

MEC - Gente, desliga a Iná, senão ela repete tudo isso em inglês!

CR - Paulo, é melhor acelerar.

PA - Como se eu fosse capaz. Bom, uma vez descoberto o Brasil naquelas circunstâncias tão comprometedoras, o que fazer? Tirar o atraso, é claro. Fácil dizer, além do mais tinha tese a fazer no horário comercial, e prazos mortais. Não resisto a outro (falso) enquadramento nobilitador do meu caso, estritamente pessoal, como quer a Maria Elisa. Encaixa bem aqui o aforismo do Monsieur Teste citado por Antonio Candido, é óbvio que pela generalidade expressa em bom francês cerebral: "trouver n'est rien. Le difficile c'est de s'ajouter ce qu'on trouve”, e quase nada pela pertinência brasileira da virada que tal máxima está ilustrando, a saber, a espécie de fibra exibida pela linha evolutiva de Machado de Assis, sobretudo se comparada ao barulho sem futuro feito pelos naturalistas mais novidadeiros, fixando e sublimando os achados modestos dos seus predecessores, cuja experiência soube assimilar e aprofundar. Mal comparando, onde haveria eu de procurar, primeiro o meu material e, segundo, identificar-lhe a tendência histórica? De um e de outro, ni notícia. Pior, nem consciência. Resultado: fora do expediente, leituras avulsas sobre o Brasil, muito desiguais e sem ponto de vista definido, como era de se esperar de alguém que começou a ler Sérgio Buarque beirando os trinta... (Ué! Passei ileso? Pensei que a Maria Elisa não me pouparia um ça se voit...) Outra coisa, igualmente paralela, por absoluta falta de meios à altura da menor veleidade em matéria de descompartimentação de uma vida mental que ainda continuaria escolar por mais de uma década (se não for muita presunção um cálculo assim tão por baixo): comecei a ler por fora os clássicos que o nosso marxismo epistemologizante (mesmo quando era com toda razão contra Althusser) considerava definitivamente enterrados, como Lukács, para não falar no ensaísmo de Adorno e Cia., quanto a Benjamin era um caso à parte. Se acrescentássemos Brecht, não por acaso encontraríamos o panteão do Roberto. História e consciência de classe continuava um livro fechado para mim, no princípio pelo mais crasso dos preconceitos (acho que no início dos anos 1970, o Michel Löwy me convidou para um seminário a respeito: agradeci, desconversei e a coisa ficou por isso mesmo; azar meu, acabei inventando a roda se penso nas sobras das "antinomias do pensamento burguês" que se podem 
encontrar aqui e ali na minha tese). Comecei pelo Jovem Hegel, fiquei animadíssimo, mas não sabia nem tinha a menor noção de onde procurar a chave que permitisse a passagem da gênese histórica (que o Lukács conseguira refazer) para a estrutura da Fenomenologia do Espírito (pois ele se limitara a resumir o livro no último capítulo; aliás mesmo problema de Dieu caché do Goldmann, e também, para ver como as coisas acabam fazendo sistema, num livro que estava lendo naquele momento, o primeiro Guimarães Rosa de Walnice Galvão, As formas do falso, onde a segunda parte literária não se juntava com a primeira, sociológica, um belo livro dividido ao meio). De modo que fiquei na mesma. Minha tese continuaria rasa, porém sem dúvida coesa nas suas duas metades. Do Jovem Hegel passei por gosto e birra (contra mim mesmo e meus maiores) aos outros livros de Lukács sobre filosofia e literatura alemãs. Enfim, também beirando os 30 fiquei sabendo que existia uma encrenca histórica chamada "miséria alemã" e que sobre ela repousava o inteiro edifício da cultura teórica do chamado "período artístico", e não só ele, tudo o mais que dele derivava, a favor ou contra, até a hecatombe de 1933. Descontando o que devia ser descontado em virtude do preço terrível e bem conhecido, exigido pelo retrocesso stalinista, naqueles livros respirava na hora do recreio, enquanto sufocava quando voltava para o serviço da tese, que ia tocando como a coisa mais sem graça do mundo, mesmo sabendo que estava fazendo direitinho a minha lição de casa. Entreguei-a no prazo (junho de 73) e voltei para São Paulo com um sentimento difuso da mais completa irrelevância extracurricular, na cabeça o Brasil do Roberto e a Alemanha do Lukács, porém como coisa a estudar sem saber muito bem para quê.
ICC - Não se pode dizer que você tenha voltado em má companhia: no mínimo dois espectros do finado Império Austro-húngaro...

MEC - E o que o nosso Cabral temporão achou de muito especial ao desembarcar na terra do pau-brasil?

PA - Altos disparates, de fazer inveja ao homem do dito cujo. Não sei se me faço entender: disparates para o meu gosto ainda arraigadíssimo de antigo almofadinha uspiano, a despeito do meu crescente mal estar de futuro defroqué, que aliás mal sabia formular. Desconchavado também por ignorar tudo e muito mais do que se passara nos barracões da extinta Maria Antonia (e adjacências, como o recente e meio concorrente CEBRAP), entre outubro de 69 e julho de 73. Já falei da carreira publicística de Giannotti no Jornal do Bairro, àquela altura creio que encerrada. Mas dela tinha notícia desde a sua estreia, que fez época. Mas não tinha a menor ideia de que a Marilena Chauí (de quem não fui aluno por acaso, pois fui aluno de quase todos os seus companheiros de geração acadêmica, Rubens Rodrigues Torres, Luiz Roberto Salinas Fortes, Maria Lúcia Montes, entre outros), que defendera não fazia muito sua primeira tese sobre Spinoza, estava estudando agora para valer Plínio Salgado e o movimento integralista. E quando se diz "pra valer", no caso da Marilena, vocês podem imaginar a dimensão da coisa.

MEC - Ou eu não entendi, ou um outro gol contra, de placa, no seu esquemão filosofia em geral e filosofia uspiana em particular, divorciada-da-experiência-brasileira. 
PA - Eu não descartaria tão rapidamente nenhuma das duas hipóteses, levando-se em conta que eu sou um péssimo expositor e que a filosofia uspiana ainda não terminou de surpreender. Mas vejamos tudo isso mais de perto, como dizia o velho. Como ignoro a bem dizer quase tudo de nossa história doméstica durante o período em que estive fora, não saberia dizer com precisão como lhe veio a ideia de tal projeto, tratando-se é claro de alguém que mexia com filosofia à maneira uspiana, muito específica. O fato é que a coisa estava no ar, e logo se alastraria nos círculos de esquerda à procura de uma brecha para encarar a ditadura. Aliás, duas coisas, no mínimo. Em primeiro lugar, uma curiosidade crescente pelos críticos autoritários da República Velha - Oliveira Viana, Alberto Torres, Azevedo Amaral, Francisco Campos, etc., e claro, Plínio Salgado. Não sei quem primeiro levantou a lebre, se no Rio ou em São Paulo, ou mesmo fora do eixo (Minas? Rio Grande do Sul?). Pelo sim, pelo não, só perguntando e lendo tudo que podia. Afinal, voltara com o firme propósito de entender a nossa choldra ignóbil, sem, no entanto, ousar pular a cerca do meu chiqueirinho. Ao que parece a deixa viera de alguns ideólogos autodesignados do regime militar à procura de uma tradição autoritária local, onde entroncá-lo intelectualmente: como o regime dava mostras de querer se perpetuar, pareceu-lhes chegada a hora de dizer às claras que os raros momentos de democracia política no país (1945-64, por exemplo) eram a exceção e não a regra. (Paulo Edmur sobre Oliveira Viana? Não sou especialista.) Não sei se foi exatamente essa a isca que a esquerda mordeu, mas o fato é que acabou encampando a tese da continuidade autoritária, de sorte que passou a analisar os rumos ideológicos da ditadura remexendo na sua provável pré-história (um pouco como os alemães à vista da flagrante inexistência de "ideias" na propaganda nazista e na correspondente indigência dos ideólogos oficiais, à procura do ovo da serpente nas entranhas do anjo torto que presidira a marcha arrevesada da cultura nacional desde as primeiras reações à vizinha Revolução Francesa). Seja qual for a natureza do equívoco (pensando bem, nem tão desparafusado assim, se lembrarmos que desde sempre nossas elites demonstraram uma incrível habilidade na articulação em proveito próprio de sobras do mandonismo de ontem com as subordinações internacionais de hoje), não se pode negar que propiciou uma descoberta em grande escala dos intelectuais que animaram a demolição da fachada liberal-oligárquica do país embrulhado pelo bovarismo dos altissonantes princípios da constituição de 1891.

Em segundo lugar, naquele início de década (1970), uma outra convicção estava se formando nos meios de esquerda, espécie de caução metodológica empurrando aquela revisão dos críticos autoritários da Primeira República: se as ideias deles acabaram pesando na Revolução de 1930 e no Estado Novo e voltavam agora a assombrar o nosso presente tenebroso, era natural então que fossem levadas a sério também na sua dimensão propriamente intelectual. Enfim, para bem ou para mal, havia pensamento político no Brasil.

\section{MEC - Forte coisa!}

PA - Grande novidade, sim senhora, essa virada. Mais importante para a compreensão das grandes manobras da esquerda àquela altura, essa inesperada rotação, do que propriamente o que ela deixava à mostra em termos de interesse cultural razoavelmente vertebrado. É que até 
então não passara pela cabeça de ninguém tomar ao pé da letra as conjecturas e refutações daqueles doutrinários, sobretudo desde que começaram a funcionar no país, e todo mundo achava que muito bem e em franco progresso, ciências sociais organizadas na forma de cursos superiores e pesquisas cientificamente respeitáveis, em função do que, tudo o que vinha antes ficava desacreditado sob a suspeita de não ser ciência, porém apenas divagação ensaística. Ou então mera ideologia em sua acepção mais rasa, simples emanação muito previsível de posições de classe facilmente identificáveis. Ou então nem mesmo isso, mas elucubrações individuais sem continuidade social e, assim sendo, nos casos raros de alguma consistência, melhor estudar a fonte europeia original do que o decalque caseiro. Ora, a reviravolta em questão sustentava que havia um pensamento político brasileiro original, que nossos ideólogos de direita nada ficavam a dever ao similar importado, e que suas ideias formavam sistemas e deviam ser examinadas em profundidade como se vivessem à europeia, gozando da relativa autonomia a que tinha direito todo pensamento. De sorte que a mesma ciência social que desqualificara a história das ideias políticas no Brasil por motivo de inexistência ou irrelevância do objeto, deveria agora reabilitá-la como gênero nobre com metodologia específica, de preferência não reducionista.

ICC - Eta nóis! O que se reconhecia com uma mão a outra se encarregava de esterilizar.

PA - Uma sinuca muito conhecida nossa, mesmo. Vocês se lembram que os novos profissionais da filosofia, que eram de esquerda por direito de nascimento institucional, achavam que pensamento filosófico brasileiro era uma miragem que só o amadorismo da direita patriótica conseguia enxergar, enquanto a filosofia universitária que eles mesmos exerciam era a mesma em qualquer parte do mundo. Ora, encarando seriamente não só a hipótese, mas agora a obrigação política (e não por acaso um antigo integralista com altas fumaças filosóficas estava no comando da Universidade naquele momento - seja dito de passagem que, segundo consta, ele teria sido não obstante muito correto com o nosso Departamento, então esfacelado pelas cassações, brancas inclusive) de uma crítica de cunho filosófico mais abrangente das ideias de Plínio Salgado e Cia., Marilena não só acertava o passo com a virada em curso na esquerda universitária como arrumava uma porta por onde a filosofia poderia afinal entrar num auditório muito mais amplo e exigente que o nosso costumeiro público cativo de sala de aula. Convenhamos, entre tantos outros lances, que não lhe faltou audácia. Não sei se poderia afirmar com toda a certeza ter sido ela a primeira, desde os tempos do (auto) desmoralizado Cruz Costa, a abordar a matéria de segunda classe que era o assunto brasileiro. Talvez o pioneiro tenha sido mesmo o Caio Navarro de Toledo que em 1973 defendeu uma tese sobre o ISEB (em Assis, mas pouca diferença faz). Seria injusto se dissesse que ele retoma um antigo estudo-resenha de Gérard Lebrun (de 1961, se não me engano) sobre Consciência e Realidade Nacional, mas sem dúvida as ilusões do desenvolvimentismo e as confusões conceituais que o acompanham eram vistas do ângulo da epistemologia francesa, de Granger a Althusser. Acresce que o ISEB era uma velha pedra no nosso sapato. Pouco tempo depois, viraria moda desancá-lo, coisa que Marilena e Maria Sylvia de Carvalho Franco se encarregaram de fazer com muita competência. 
Mas voltemos à Ação Integralista Brasileira. Não é difícil entender a estupefação de um retardatário como eu, em todos os sentidos. Além do mais, de torna-viagem recente, não tinha qualquer notícia das circunstâncias que incitaram uma uspiana da gema a juntar filosofia com Plínio Salgado.

MEC - Você não tem, portanto, nada que reclamar da divertida incompreensão de seus colegas, vendo-o pular, dez anos depois de Hegel, para Cruz Costa.

PA - Sem dúvida, mas somente no caso da matéria brasileira comprometedora arrastar consigo o ponto de vista filosófico que a encarava como um moinho de vento, não permitindo em consequência que ele saísse ileso da empreitada, tão puro e seguro de si como entrara. E não era bem esse o caso, pelo contrário. Mas voltemos ao purista chocado. No fundo estava dividido, além de muito cru para o calor da hora. Côté cour, reação rotineira: isso não é assunto digno de qualquer interesse, sobretudo filosófico. Além do mais, as matérias eram incongruentes. Côté jardin, na condição de schwarziano recente, ainda sem experiência à altura da minha nova fé de ofício, alinhava, por exemplo, com Sérgio Buarque, na opinião sumária de que os integralistas não eram mais do que um bando de neurastênicos e, a ser assim, mereceriam quando muito um estudo satírico, gênero fotografia da estupidez, o que Mário de Andrade mais prezava em Oswald. Enfim, Marilena podia estar equivocada, porém no rumo certo (além do mais estudando exaustivamente o período entre 20 e 38). Quanto a mim, se me fosse perguntado, não saberia de modo algum explicar por que aquelas duas metades não poderiam nunca se juntar (pelas razões sobre as quais só muito mais tarde teria alguma clareza), embora fosse isso mesmo que desejava ver do fundo do meu recém cristalizado sentimento de irrelevância filosófica.

De minha parte, para voltar aos tateios bisonhos do nosso memorando, enquanto observava à distância as idas e vindas da Marilena, que àquela altura já prenunciava o fenômeno público que logo mais viria a ser, dominando a cena filosófica nacional ao longo daquela década de 70, aliás, avant scène curiosa e simetricamente compartilhada com o Giannotti, eu ia tocando o serviço nos dois registros ao meu alcance: na pista a que me condenava a tradição, estudava a Ciência da Lógica com vistas ao complemento natural da tese apenas concluída, do ângulo marxista o mais remoto que me permitisse identificar, naquele livro até hoje fechado, o nexo estrutural entre lógica e sociedade (poucos anos depois arrumaria um expediente para essa volta do parafuso que ainda não dei, juntando dialética negativa, vida intelectual e defasagem histórica); na outra pista, inaugurada pela descoberta temporã dos escritos lukacsianos sobre a cultura alemã, mexia com a esquerda hegeliana e os demais ideólogos alemães propriamente ditos, agora filtrados, como disse, pelo prisma da "miséria alemã" e da dissolução do sistema hegeliano, possível súmula da falência do gênero filosofia em geral. Está claro que à maneira brutalista do Marx da Ideologia Alemã: e como não tinha condições de generalizar aquela primeira entrada no estado de não-filosofia, concentrava-me de preferência na reconstituição historiográfica da virada. Com um elemento novo, várias vezes mencionado nesta conversa como um resultado óbvio, a saber: outro acontecimento parisiense que trouxe na mala era o Sartre do Idiota da Família, duplo acontecimento, primeiro porque se tratava de um verdadeiro Dezoito Brumário 
da Literatura Francesa (se me lembro bem, batismo aparecido numa conversa com o Roberto, enquanto os três volumes iam pingando) e como tal o mapa da mina para muitas coisas, no centro dele o grande revertério de 1848 , que desde então comecei a revirar e colecionar tudo que me caía nas mãos a respeito (depois parei, como todo brasileiro veleitário, porém armazenando à espera de dias melhores), e como ao mesmo tempo estava lendo Lukács, comecei a ver sob outra luz a centralidade daquela virada que na tradição marxista o Lukács fora o primeiro a exponenciar. Um artigo que escrevi em 76 a pretexto de Schopenhauer data dessa confluência; a outra dimensão daquele acontecimento, era o baile que o Sartre redivivo, mesmo prolixo e às vezes errado, dava nos ideólogos franceses do momento. Aliás um chapéu de duas pontas, se era fato, como comecei a ruminar e ainda não desesperei de pôr isso no papel, que bem podia estar ali a pré-história da famigerada Ideologia Francesa: e se, ao remontar a corrente, eu desse além do mais com a raiz comum que lhes inspirava, aos ideólogos parisienses, o namoro com a pré-história alemã dos Jovens Conservadores, cuja árvore genealógica bem poderia deitar raízes naqueles aspectos da Ideologia Alemã do segundo oitocentos que os novos modernistas franceses mais prezavam, em particular Nietzsche, é claro? Pus a ideia na mala e voltei para São Paulo, onde encontrei minha colega Marilena Chauí esgrimindo no mais elevado estilo filosófico com a Razão Autoritária encarnada por Plínio Salgado. A esses dois registros limita-se minha vidinha filosófica de escritório a partir de 73, também posto de observação das grandes manobras oposicionistas da filosofia uspiana, cujo front mais avançado se abria a cada ano nas formidáveis reuniões da SBPC.
MEC - Se eu não me atrapalhei com as datas, estamos enfim (e ponha enfim nisso!) a dois anos do primeiro texto do livro que em princípio deveríamos estar comentando, a título de explicação necessária vinte anos depois. Pelo visto, ficaremos na gênese, deixando a estrutura para as calendas.

CR - Não vejo mal nenhum nisso. Aliás, tanto faz, pois a conversa já desandou faz tempo. Nunca me passaria pela cabeça que um simples livro de filosofia desse tanto pano pra manga, ainda estou pra ver conversa tão espichada. Ia continuar, mas me lembrei da tal mania brasileira da metafilosofia e outras metas sem filosofia.

ICC - Se está espichando, vamos encurtar. Vejamos se eu consigo resumir a camisa de onze varas em que estava metido o nosso entrevistado nos seus dois primeiros anos de torna viagem, enquanto se preparava muito desconsolado para iniciar a redação da série de estudos, finalmente abandonados por volta de 83, e que compõem a infeliz obra na berlinda, de título ainda inexplicado (fora a rima óbvia com outro anterior, na verdade muito posterior: Sentimento/Ressentimento da Dialética). No fundo, nosso amigo aqui presente não tinha uma ideia muito clara da descoberta que fizera sob os auspícios do Roberto Schwarz - o Brasil enquanto complicação cultural relevante, chão histórico de uma experiência intelectual só aparentemente rasa, mas cuja possível profundidade e alcance precisavam ser cavados. Embora não soubesse como, vindo como vinha da cultura de gueto filosófico. Onde faltavam ideias claras sobre o que fazer, sobrava uma sensação muito aguda de irrelevância, de coisa sem graça a coisa filosófica. Imagino que esse sentimento foi confirmado pela publi- 
cação, no ano de 74, do ensaio do Roberto sobre o Anatol Rosenfeld, recém falecido (para meu eterno pesar), onde por contraste devia ficar bem nítido o divórcio entre conhecimentos especializados e interesse filosófico, entre crítico da sociedade, da cultura e filosofia em geral, pois a uspiana era de ponta. Ora, nosso amigo aqui desembarca e encontra um cenário que o surpreende por se mover na direção de suas aspirações confusas, mas simplesmente não entende nada. Por isso, vê apenas disparate. Ainda por cima, pouco ou nada sabia da conjuntura, tanto é que em 74 ainda votaria nulo, um gauchista retardatário na primeira derrota eleitoral da ditadura. Ignorava o que se discutia no CEBRAP, mas sobretudo o passado de tais discussões, e que eles estavam assessorando o MDB. E também na UNICAMP, o que se pensava da economia brasileira (se afinal se completara o Departamento de Bens de Capital ou não), os que já estavam lá e os que estavam chegando do Chile depois do golpe, etc. Tampouco estava a par das revisões e balanços suscitados pelas comemorações dos 50 anos da Semana de 22. O pós-tropicalismo. Os tenentes e as novas teses sobre a Revolução de 30 (e aqui voltamos à Marilena e seus amigos historiadores: outra novidade, para ele, essa liga). A nova geração de críticos literários já em plena atuação, Davi, Lafetá, Zé Miguel (este último um pivô na reformulação em curso dos juízos sobre a música brasileira, e nesse rumo a estreia auspiciosa do Gilberto Vasconcelos). E para não encompridar demais, deixo de lado teatro, cinema e artes plásticas e, neste último capítulo, a voga da pintura acadêmica. Enfim, a repressão comia solta, mas o país intelectual começava a andar. Depois vieram as primeiras greves no $\mathrm{ABC}$, mas agora já estamos em 77 , e o nosso professor ainda insistindo em artigos herméticos sobre ideólogos alemães de segunda linha.
MEC - Isso é resumo ou requisitório?

ICC - É que você não sabe a dureza que foi trazer para a terra de Paulo Emílio e Décio de Almeida Prado (que naquele momento estavam publicando, respectivamente, livros sobre Humberto Mauro e João Caetano) o balão cativo da filosofia uspiana. Com a Otília (Arantes) - o Celso Favaretto que o diga - a operação foi bem mais rápida e bem-sucedida. É verdade que com Estética a coisa é quase natural, e antes do fim da década o CEAC (Centro de Estudos de Arte Contemporânea) já estava funcionando, com revista e tudo (Arte em revista). Pois então, o país intelectual começava a se mexer empurrado e empurrando a Abertura, e a filosofia idem, a julgar pela crescente participação dela nos comícios oposicionistas anuais da SBPC. Mas, em que direção exatamente? Ao encontro da experiência brasileira, confluência impossível (por tudo o que já vimos: e quanto a mim, acho que estou de acordo, até porque também tirei filosofia e conheço bem esse povo), no entanto desmentido pela intervenção espetacular da nossa ídala, Marilena Chauí, com a qual não podia concordar inteiramente o nosso schwarziano aqui presente, convencido de que ideologia no Brasil, sem ser necessariamente elucubração individual sem antes nem depois, é sempre de segundo grau, de sorte que a crítica frontal acaba, no melhor dos casos, arrombando portas abertas. Mutatis mutandis, eram igualmente estrepitosas as aparições do Giannotti, filósofo oficial dos dissidentes e cassados reunidos no CEBRAP, um bom número dos quais era remanescente do Seminário Marx, como se sabe. Agora me pergunto, à vista desta presença em uma cena cada vez mais barulhenta (lembro-me de um pronunciamento apoteótico da Marilena em 1977, o TUCA pondo gente pelo la- 
drão naquela SBPC) da filosofia uspiana na pessoa dos seus dois principais representantes: do que se queixa o prezado professor? Ele e a sua má consciência profissional?

PA - A coisa está ficando delicada. E como vem ocorrendo, seus problemas já vêm com solução: como você mesma acabou de afirmar, por definição digamos histórica, filosofia profissional (acrescentando sempre que não há outra) e vida nacional não podem se encontrar, a segunda não podendo ser nem objeto a ser glosado nem chão histórico para a primeira, salvo para complicar-lhe a existência, toda vez que ela resolveu sair a campo, e era o que estava acontecendo pela primeira vez naquela quadra. Quanto ao mal-estar na cultura filosófica uspiana, o problema justamente é que não havia nenhum. Os que a timidez não retinha, simplesmente deram o passo à frente que julgavam exigido pela ordem do dia, é claro que tacitamente respaldados pela sensação mais ou menos consciente de que o período de acumulação primitiva estava a bem dizer encerrado.

Vamos por partes. No que concerne à sensação de fantasia sem proveito, só se tem registro de um rompante. E logo da parte de quem? Do Porchat! Na aula inaugural de 68, desassossego encerrado com sua posterior conversão à filosofia da visão comum do mundo: sem dúvida um curioso desconforto, por assim dizer espontâneo, diante de algo que no fundo, no fundo, lhe parecia puro teatro, pois não lhe parecia que seus colegas estivessem sendo sinceros na naturalidade com que liam filósofos abstrusos que punham o mundo e seus derivados entre parênteses, a seu ver mera afetação, aculturação forçada porque contra a natureza. Mas não contra a natureza literária de seu amigo Bento Prado que podia sem pestanejar assegurar- -lhe que nunca tropeçamos literalmente nas coisas, que o argumento profissional inaugurado pela dúvida cartesiana era uma hipérbole como tantas outras, etc. Enfim, um pouco mais de persistência e o Porchat acabaria reencontrando Cruz Costa e os demais filhos da terra, mas acabou voltando aos tópicos mais ortodoxos da especialidade.

Encerrado o episódio, os mais tímidos continuaram na sala de aula e os mais extrovertidos, como o momento era de combate, foram à luta. Marilena e Giannotti na linha de frente, sendo que em nenhum momento jamais lhes ocorrera a hipótese desagradável da filosofia não poder mostrar com armas próprias e de abrangência máxima a que, afinal, teria vindo, dar a última palavra, é claro. E como sabiam se impor em grande estilo argumentativo, cada triunfo confirmava menos o óbvio talento de um e outro (mas isso também, está claro) do que a supremacia clássica daquela disciplina de última instância.

Além do mais, é preciso não perder de vista uma outra circunstância favorável, devida em grande parte à nossa ascendência francesa: sem ser necessário professar ao pé da letra o ideário estruturalista da década anterior, e ainda em plena evolução, podíamos nos beneficiar do dito surto epistemológico continental que ao associar filosofia e as novas ciências humanas acabara nos familiarizando um pouco por osmose com linguística, etnologia, história da longa duração, psicanálise, etc., o que fazia de um filósofo uspiano em dia com a nova bibliografia, que também primava pelo radicalismo político, uma espécie de debatedor universal, sem falar que Giannotti era igualmente especialista em Marx, àquela altura em pleno apogeu. Quanto à Marilena, a tudo isso e muito mais (como referências sistemáticas à cultura popular e conhecimento dos frankfurtianos, coisa que Giannotti proibia) juntou 
seus novos estudos brasileiros, de cujo pormenor, mesmo por alto, ainda não tratamos.

Repito o bordão: vamos por partes, neste capítulo de agora da filosofia universitária contra o pano de fundo da vida nacional. Como não fazia má figura, muito pelo contrário, vocês me dirão que preciso engolir tudo que falei. Deu-se então o seguinte naquele meio de década: de tempos em tempos no pequeno mundo filosófico surge a pergunta (em alemão ou francês fica mais fino): Wozu noch Phiolosophie? À quoi bon des philosophes? ou Porquoi des philosophes? Trata-se, é claro, de uma dúvida para inglês ver, mera cláusula retórica que mal esconde seu propósito apologético. Não é menos verdade, todavia, volto a lembrar, que estes parafusos hamletianos refletem sem muito erro o momento "sentimental" característico da condição moderna da filosofia, às voltas com os problemas de demarcação decorrentes de seu ingresso no sistema das ciências positivas e nos demais processos de diferenciação e legitimação cultural. Era preciso mostrar a toda hora que ainda ocupava o lugar de honra dos fundamentos. Conhecemos a maneira direta, transcendental, dessa demonstração, que remonta à lenta cristalização do gênero "filosofia primeira”, de Descartes a Kant, passando pela variante decisiva do "enquiry" dos empiristas ingleses, um gênero movido a teoremas sobre a lógica do conhecimento, para enfeixar numa única fórmula o cruzamento das duas linhagens em que se costuma reconhecer o específico filosófico (no jargão de meio século atrás), o lógico e o transcendental.

Vocês querem continuar a aula? Então vamos. Depois não reclamem. Também sabemos que nos anos 30 e 40 do oitocentos alemão aquela apologia da filosofia em separado precisou conviver com sua sombra, a não-filosofia sem território fixo da pequena legião dos dissidentes dos mestres-pensadores (os fundacionistas profissionais), homens sem profissão, de fato professores interditados ou publicistas voluntários, enfim, autores avulsos, no geral remanescentes da esquerda hegeliana, cujo mote, como vimos, girava em torno do fim, ou melhor, dissolução da filosofia, seja por motivo de realização dessublimada (na suposição de que a supressão da abstração unilateral de um âmbito cultural socialmente isolado produzisse efeitos emancipatórios), ou radical reconversão das virtudes redentoras da Teoria, refluindo enfaticamente para a inefável autenticidade da existência privada, espécie de carapaça protetora compensatoriamente contraposta ao programa alternativo da vida pública expandida ao máximo, aliviada da carga imaginária da dimensão política enquanto simulacro do universal falsamente postulado como existente na fantasmagoria do Estado. Pois não é que a marcha da Aufklärung (estou continuando a aula, como combinado), processo bifronte que ao esclarecer obscurece, acabou empurrando, por força da dita racionalização demolidora de barreiras tradicionais (como pensam os MM. Homais do Positivismo), essa última variante, responsável pela elevação da existência indevassável à condição de mistério metafísico, novamente para o lado profissional do enlace lógico-transcendental (ou seu equivalente linguístico, para nos atermos à tradição do exemplo que darei a seguir: onde se lia representação, leia-se significação, referência, denotação, etc., etc.)?

Estou pensando, é claro, no Tractatus do Wittgenstein (creio que mais uma vez), porque com ele aquela distribuição de tarefas, de que também já falamos, positividade de um lado (se quisermos, reprodução sistêmica da sociedade como conjunto de meios articulados por 
nexos instrumentais), do outro, simplesmente justaposto e por isso mesmo plenamente justificado, proximidade absoluta da existência no seu estado bruto, o avesso metafísico daquela fachada positiva, avesso completamente raso, por assim dizer, já que a miragem da profundidade se desfez juntamente com a abolição dos problemas filosóficos, por serem falsos problemas (como sabe toda mente arejada e esclarecida: esse o curso da citada Aufklärung, vista agora no seu lado raciocinante, versão degradada e por isso positiva da Crítica da Ideologia, que celebra a dissipação do atraso obscurantista mergulhado na mais autoritária fantasmagoria, já que o absoluto é privativo dos raros capazes de mostrá-lo com o dedo).

Pois então, para continuar, uma tal divisão do trabalho se apresenta neste caso, aliás com muita coerência se pensarmos na idade histórica do material e sua transcendência correspondente, explicitamente impulsionado pela intenção de resolver de uma vez por todas o problema da filosofia, de responder de modo radical à pergunta "à quoi bon des philosophes?", uma questão de legitimidade e demarcação, dúvida moderna por excelência como ficou dito, a que Wittgenstein dará uma resposta na forma bem calculada do paradoxo (um expediente retórico poderosíssimo na apologética religiosa, como deve saber todo leitor de Pascal). Por um lado, resposta encaminhada para fazer justiça à grande tradição filosófica do Ocidente: de fato, ou a filosofia tem a ver com o Absoluto, o Incondicionado e Cia., ou não é nada e, como vimos, essa quintessência sai reforçada da empreitada, desde que não seja mais o alvo equivocado de uma "teoria". Por outro, e por via de consequência, a demonstração por proposições autodestrutivas por motivo de reflexividade impossível numa linguagem unidimensional, a prova por paradoxo interposto de que aquela maneira direta (inaugurada pelos pais fundadores Descartes/Kant) de apontar o fundamento e o seu lugar não está mais disponível para o discurso filosófico moderno e isto no momento mesmo em que tocamos o fundo, sem intermediários (os bergsonianos não têm do que se queixar, como outrora os amigos de Schopenhauer, se ainda faltassem bons testemunhos de que a conjunção amistosa de misticismo e ciência é a prova dos nove do mundo criado pelo Capital). Daí o grande achado, o charme objetivo do livro, sua composição de vanguarda (um pouco como os torrões de açúcar de Marcel Duchamp). Numa palavra, também ele, o Tractatus, um livro de filosofia para acabar com todos os livros de filosofia. Mas por que estamos falando disso mesmo?

MEC - Só voltando a fita. E não sei se adianta, porque eu acho que ficaríamos na mesma. Já deu pra perceber, faz tempo, que para você qualquer pretexto é bom para fazer cair as mesmas fichas de sempre. E não me venha com a tal queda brasileira pela metafilosofia. Pode até ser, mas também não precisa exagerar, né?

PA - Pois aí vem mais, agora me lembrei. Lá pra trás, ou o tempo todo, está uma questão a meu ver nada desinteressante, acho que fatal: quais as chances de um camarada que mexe profissionalmente com filosofia no Brasil (filosofia tout court, é óbvio, não filosofia brasileira, uma tarefa de segundo grau no caso, e necessariamente de cunho profissional: amador não vale, mesmo de talento, pois a ser assim estaria na antecâmara, preparando-se para dar o mau passo de que estamos falando), quais as chances de vir a engrenar, para bem e para mal, num sistema específico de contradições a que habitualmente damos o nome 
de vida nacional, dando de barato (agora) que na ausência desse nexo não se pode falar de existência intelectual propriamente dita, valendo o mesmo para o caso de um eclipse do referido campo de forças nacional, quando cai a voltagem dele, como já foi observado (e não por mim), e a vida do espírito também naufraga na irrelevância, agora ofuscada pela miragem da globalização. Ora, a prova de que esta dúvida não é mera implicância de um materialista vulgar (ou de um sociólogo racional das ideias) está no fato de que aquele grande lugar comum da retórica filosófica, "a quoi bon des philosophes?", finalmente encontrou a sua vez entre nós (lugar comum que um habermasiano encamparia observando que afinal nele se exprime uma dimensão óbvia do "discurso filosófico da modernidade", dimensão reflexiva que também se poderia chamar "crítica”, pois tendo-lhe fugido por definição o solo das certezas objetivas tradicionais, a "modernidade" nada mais é do que esta busca incessante de autolegitimação, daí a frequência daquele expediente retórico, uma espécie de protocolo da modernidade filosófica: criado o caso, onde a regra?). E isso quando no meio da década de 70, secundando em parte o surto de breve estremecimento da fé no ofício de parte do seu amigo Oswaldo Porchat, Giannotti lançou o brado (de convocação à SBPC daquele ano de 75): “por que filósofo?". Atenderam ao chamamento vários colegas uspianos, Bento Prado Jr., Rubens Rodrigues Torres Filho, Gérard Lebrun. Marilena também, não por ser diretamente interpelada, mas ao seu jeito e maneira, a bem dizer durante o restante da década, se é que já não começara a responder a uma suspeita que ninguém formulara ainda, atacando Plínio Salgado e herdeiros. Porchat, como vimos, também se antecipara. Depois de tomar um fartão de historiografia goldschmidtiana, estava meio enfarado e não sabia o que fazer com aquela comédia literária toda, mas naquele momento o "homem comum" que carregava consigo sem saber enquanto pairava nas alturas everestianas da filosofia praticada na Vila Buarque já decidira a parada em favor da "visão comum do mundo". Aliás, todos os concernidos sabiam muito bem que a pergunta era simples ocasião para grandes manobras em defesa da filosofia, mesmo fingindo atacá-la nos prolegômenos de praxe. Estavam todos persuadidos, com razão, de que a filosofia entre nós ia muito bem obrigado.

Mas a pergunta estava no ar. Sobretudo na França, depois de 68 e do Estruturalismo. Mas desta vez o sobressalto era endógeno, como veremos. No ano seguinte, novo ato da versão nacional da peça "elogio da filosofia" - Seminário sobre o tema "profissão: filósofo". Bento em grande forma puxando o cordão dessa gentil mascarada: encerrado seu período formativo (anos 60, no meu calendário uspiano), podia-se dizer sem favor que todo mundo conhecia seu métier e que naquele momento os filósofos de profissão entre nós estavam prestes a decolar em grande estilo. De sorte que ao amigo Bento Prado cabia dar corda ao falso motivo da hesitação flertando com os ataques de Nietzsche à filosofia universitária (que por sua vez secundava o paradoxal kantiano Schopenhauer) sem precisar arredar pé da sua fausse position, aliás confortável, pois a filosofia universitária dera certo em São Paulo e ninguém em sã consciência pretendia retornar à condição de "homem sem profissão". Tanto era assim que o nosso herói podia se dar ao luxo de fazer graça com a gigantomáquia de um Derrida, denunciando o moinho de vento armado pelo conluio logocêntrico entre Filosofia e Instituição no Ocidente. Tudo isso não obstante, nessa mesma conferência de 76 sobre a condição moderna da filosofia, um ganha-pão 
como outro qualquer, o Bento novamente (como no artigo de que já falei, de 68, sobre o falso problema da filosofia no Brasil) lembrava de passagem (outra observação preciosa que dessa vez eu registrei muito bem e pus de lado à espera da primeira ocasião) que no Brasil as coisas se passavam de outro modo, rigorosamente invertidas se comparadas à sequência europeia. Aqui, a cultura filosófica (faltou acrescentar que depois de Kant e do Idealismo Alemão só pode ser escolar, na acepção acadêmico-institucional do termo, mas também no sentido de aparato conceitual específico desenvolvido em separado) precedera o seu objeto, no caso a cultura livre, viva ou independente, de cuja densidade carecia para poder funcionar (mas aqui, como sabemos, o enquadramento kantiano da questão descarrilava ligeiramente), daí o efeito cômico da fala de Derrida sobre as relações perigosas entre pensamento e instituição, quando em nosso meio devíamos tudo ao artifício do transplante que produzira a instituição esperando que o tempo se encarregasse de fornecer-lhe o recheio. Poderia o nosso amigo ter dito, e quase chegou a dizer, que por esse caminho acabaríamos gerando primeiro um estilo que em seguida precisaria sair a campo à procura de assunto (e com os mais habilidosos foi isso mesmo que se passou). No que tange ao futuro dessa observação rara, as coisas ficaram por ali mesmo. Ou por outra, um pé atrás o Bento sempre teve, mas não a ponto de dar uma resposta atravessada à momentosa questão proposta à deliberação de nossos maiores pelo Giannotti no ano anterior, "por que filósofo?" - e pela resposta dada pelo próprio Giannotti veremos que para ele estava subentendido "por que filósofo, no Brasil, hoje?".

Recomecemos então pelo Bento, que devia estar mesmo com a pulga atrás da orelha, a julgar pela resposta ex- traoficial que deu numa mesa de bar, enquanto procurava meio embananado algum assunto dissertável em resposta à pergunta entre arrevesada e óbvia que o confrade em má hora lhe propunha: sou bem nascido, embora sem um tostão para tinir com outro, poderia escolher sem pressa entre as várias carreiras liberais, mas por que, meu Deus, por que justamente filósofo?

ICC - Remordimientos paraguayos...

MEC - A colega poderia ser menos hermética?

ICC - Posso mesmo? Então tá. Esse puro teatro do Bento é fingimento de segundo grau. Muito à vontade no seu papel, ele fingia sentir o mal-estar que deveras sentia, mas não sabia, salvo na hora difícil da falta de assunto? Pois essa encenação me lembra algumas observações do Roberto Schwarz sobre O nome do Bispo, uma das obras-primas imperdíveis da Zulmira Ribeiro Tavares. Nesse romance, a crise intelectual de um herdeiro de nome ilustre paulista é comandada por uma curiosa mescla estilística entre as regiões menos nobres do corpo e as mais elevadas aspirações do espírito. Segundo o Professor Schwarz, essa mistura é própria da marcha recalcitrante de nossas elites em direção da modernidade ideológica. Daí ele recorda uma reflexão recente sobre o papel da sociologia no país vizinho supracitado, a que teria servido de título a seguinte pergunta: “¿Para qué Ciencias Sociales en Paraguay?” Foi dessa alta indagação que me lembrei ao ouvir a clarinada do Giannotti: “por que filósofo no Brasil?”, junto com o comentário exato do Roberto, reforçado pela boutade do Bento. O Roberto diria que, lá como cá, o questionamento abrupto, dirigido aos fundamentos, é de inspiração hei- 
deggeriana (e por falar nisso, já disse e repito: o presunto marxismo do Giannotti, para usar uma palavra dileta dos nossos vizinhos hispânicos, nunca me convenceu, fosse ele ocidental ou coisa que o valha; o Paulo vai me desculpar, mas a recaída de hoje no existencialismo de ontem, para mim, continua uma peripécia circular), enquanto o propósito é o nosso de sempre, a saber, contribuir cordatamente para o aprimoramento da vida do espírito num país tão carecido de se atualizar.

Ainda tem mais. Como se pode perceber pela comédia involuntariamente sincera do amigo Bento, cuja versão paraguaia o Roberto concebeu em termos bem mais diretos, pensando no outro paulista, é claro, o imaginário, e seus sonhos de suprema elegância e cultura, reduzidos a seu nível municipal na hora do vamos ver da cor local, com base numa anedota real: diante da pergunta, um compatriota despreparado e a quem as ciências sociais podem parecer perfeitamente dispensáveis, bem poderia ter reagido como o outro conterrâneo da anedota: "¿Yo? me cago en Picasso". Assim, acho que valem para o toque de reunir giannottiano, corretamente filtrado pela piada do Bento, as reflexões paraguaias do Roberto: seja em Asunción, seja na Belo Horizonte da SBPC, as questões radicais que costumam acompanhar as disciplinas modernas parecem chiques a uns, supérfluas e presunçosas a outros, mas sobretudo irreais a todos. Pronto! Falei.

CR - Ainda que mal pergunte, Paulo: por escrito, oficialmente, a resposta do Bento Prado foi mais pro radical em abismo ou resvalou de leve no escatológico episcopal? Estou curiosa, porque nós encomendamos a ele o Prefácio do seu livro.
MEC - Eu, no lugar dele, não pensaria duas vezes. E se houvesse um pouco de lógica nisso tudo, onde se lê Picasso, se poderia ler perfeitamente qualquer outro nome de menor quilate.

PA - Pois o Bento virou, mexeu e fez, é claro, o seu dever com a perícia uspiana que ninguém até hoje igualou. Isto é, uma peça do gênero Elogio da Filosofia, só que indireto, uma apologia da Sofística mediante um confronto direto com o pobre Husserl da Crise da Humanidade Europeia e a Filosofia, a cujo fiasco já aludimos, mas de um modo com o qual o Bento não concordaria nem um pouco. Não pelo Husserl, no fundo pouco se lhe dá, mas pelas segundas intenções (deixando de lado as demais), aliás muito explícitas, de se aproveitar dos lados mais desfrutáveis da profissão. O que ele também gosta de fazer, desde que o indigitado filósofo seja o outro e, no elogio em pauta, o Outro do Sofista, mais especificamente na pessoa de um humanista incorrigível, beatamente pasmo diante do descarrilamento da Razão, daí o “pobre” Husserl, além do mais surpreendido em flagrante delito de etnocentrismo. Tudo ali pedia pancada, culminando na ideia mirabolante do filósofo-funcionário da humanidade, demasia sem tempo que não resiste a um simples livro de ponto ou a uma não tão simples mesa de chope do amanuense Belmiro. Mas como este último também filosofa e não se queixa de ser profundo, o nosso Bento sai (bem) pela tangente, não diria fantasiado de sofista, pois aqui a adesão é sincera a um personagem sob medida, num certo sentido bem pouco europeu (para o gosto do eurocêntrico Husserl, muito parisiense no entanto no seu modo ultramoderno de exibir como uma façanha ontológica o que é mera estilização do jogo infantil com as palavras e as coisas), sob 
medida por se encontrar desobrigado não só do esforço de pensar norteado por constrangimentos lógicos mais ou menos estáveis (uma tópica de ocasião casa bem com a inconstância de um estilo à procura de assunto) mas sobretudo por se ver aliviado da responsabilidade, a seu ver filistina, de arcar com os fins últimos da humanidade (ou do Sacro Império Romano-germânico, na tirada de Schopenhauer contra o oficialismo do Idealismo Alemão), para continuar no mesmo diapasão condoreiro.

Quer dizer, mais uma vez, não só de pirraça mas também com intuito programático, o Bento apostava no antifuncional, certo de que pelo menos alguma graça encontraria na ostensiva adesão à função contrária, "anarcôntica", na terminologia ad hoc que inventou na ocasião, pastichando sua vítima atrelada ao jugo objetivo de "telos", "arché" e outras coisas do gênero. Dá para desconfiar que o alvo não era bem o alemão indefeso e a sua ainda mais desacreditada Ilustração in extremis. Aqui uma dessas viradas não planejadas em que novamente o fato involuntário de pensar em brasileiro parece mesmo fazer sistema. Por Husserl interposto, Bento dissertava ad hominem, e o homem no caso era o próprio Giannotti, que cometera a imprudência de tomar as coisas pela raiz (mas a circunstância desta vítima tão próxima não impedia nosso herói de ter antecipado de uma década a próxima rodada do confronto de turno, Foucault x Habermas, tanto o melhorismo da Teoria Alemã quanto o satanismo de escritório da Ideologia Francesa permanecem iguais a si mesmos).

À vista do exposto, acho que não estou forçando a mão se disser que na alergia de nosso personagem à ideia muito exigente da filosofia como ciência rigorosa, superlativamente encarnada pelo seu ex-professor e colega Giannotti, alguma coisa se devia ao mau pressentimento de que o filósofo rigoroso em questão estaria atribuindo a si próprio um papel cívico e constitutivo que justificasse carreira e vocação. No que o Giannotti andava certo, ou pelo menos acompanhando pela força da tradição o imperativo familiar que manda associar iniciativa intelectual e edificação nacional. Ora, sem precisar pensar muito no assunto, farejando a proximidade do famigerado senso de missão do intelectual brasileiro, Bento instintivamente bateu logo na tecla oposta, a da libertinagem, filosófica no caso, sob a roupagem de empréstimo da sofística, talhada no entanto segundo o figurino do solitário à moda de Rousseau, il me faut une philosophie pour moi, e esta, Bento sempre a imaginou um contra-discurso, uma contradição, enfim, qualquer coisa que no plano mais expressivo da linguagem espelhasse o outro polo de nossa vida intelectual, o lado alma de escol exilada da sociedade.

Tudo isso, é óbvio, cum grano salis, e muito, pois o nosso autor não ignora a enorme distância histórica que o separa de sua inspiração mais remota, nem lhe ocorreria qualquer transposição literal das idiossincrasias tão características do byronismo dos acadêmicos literatos de meados do oitocentos paulistano, pois era isso que de minha parte vinha insinuando, sem querer com isso sugerir que o amigo Bento tenha algum dia reproduzido em chave filosófica as tropelias de um Aureliano Lessa ou Bernardo Guimarães. Até porque, sabemos que esses polos são alternos, que entre nós a construção positiva e o estado de secessão se revezam, que o veleitário e o empreendedor podem perfeitamente conviver nos nossos intelectuais bifrontes. Assim não estarei contando nenhuma novidade se lembrar que o mesmo profeta da filosofia antifuncional, sempre que convocado (pois voluntário nesta matéria, isto 
nunca foi) saiu-se muitíssimo melhor do que a encomenda. Revelou-se um organizador da cultura de primeiríssima ordem, pra gramsciano nenhum botar defeito, desde a alta política de pacificação de guerras civis corporativas à animação de instituições bem planejadas (por ele mesmo), sem falar no seu principal trunfo, os ofícios, relatórios e outros instrumentos de combate, invariavelmente concebidos e realizados num estilo terso e escorreito, para admiração e confusão do destinatário que não percebesse de saída que tinha em mãos um pastiche ao quadrado.

Mas não era bem disso que eu estava querendo falar, do filósofo uspiano antes ou depois de atingir a idade burocrática, que o Bento aliás sempre exerceu interinamente. Ao sentir no ar alguma coisa como a nossa atávica vocação para a responsabilidade personificada pela intransigência metodológica do Giannotti, que de um modo ou de outro haveria de se manifestar no teor da resposta à pergunta que ele próprio formulava e neste caso (seja dito a favor dele) sem se preocupar a mínima com o tópico clássico "elogio da filosofia", imagino que o Bento tenha tido uma certa sensação de dejá vu. E reagiu como vimos. A quê, exatamente? Agora sou eu que especulo, com base no que disse na ocasião Giannotti e ele não podia prever. Reagiu a uma variante filosófica daquele mesmo atavismo nacional a que o Giannotti dava seguimento sem precisar pensar duas vezes, porém uma variante antiga embora não tão longínqua assim, e que ele Bento conhece muito bem, até escreveu a respeito (passa por aí também a verossimilhança da minha projeção) alguns anos antes, uma variante antigona, mais precisamente um estilo de lidar com filosofia que em princípio deveria ter ficado para trás e sobretudo sepultado pela nossa maneira uspiana de mexer com filosofia, que enfim se firmara em escala nacional, não mais como coisa de paulista afrancesado, mas simplesmente como prática universitária rotineira. Mais grave ainda: um tipo de raciocínio que por fidelidade àquela mesma tradição intelectual só poderia ser nacionalista, e pior, vitimado pelo mesmo fiasco do nacional-desenvolvimentismo derrotado em 64.

ICC - Espera um pouco! Você está brincando com a gente? Giannotti e Álvaro Vieira Pinto reconciliados no mesmo altar da pátria? ISEB e USP, degraus na mesma escada do progresso? Bom... Pensando bem, faz sentido, gente! Acho mesmo que tem uma certa lógica...

MEC - Agora é você que está abusando!

ICC - Será? Olhe aqui: antes, burguesia nacional anti-imperialista, mas quem depois rasgou a fantasia do capitalismo nacional acabou, impelido pelo mesmo progressismo de antes, operando (talvez a título precário, quem sabe?) a mesma associação dependente com o sócio majoritário de sempre, com uma pequena diferença, tenho que reconhecer. O sócio menor que lhe passou procuração também o incumbiu de desmontar, para efeito de big business, o aparelho estatal de cuja gorda proteção lhe valeu outrora o título fantasioso de "nacional" (mil aspas, por favor).

MEC - E o nosso filósofo número um? Você também está achando que dá para fazê-lo sentar na mesma carteira do último da classe, ou que pelo menos levou a fama?

ICC - O que o Giannotti pensava, em meados dos anos 70, da função ou disfunção da filosofia no Brasil, eu não sei, o Paulo está aqui pra isso (não precisa agradecer), mas o que 
ele pensa hoje eu sei muito bem. Entra mês sai mês, lá está ele em jornal ou colóquio dizendo o quê? Que como amigo e antigo companheiro do Seminário Marx não pode recusar ao Presidente da República a sua confiança e, assim sendo, lhe compete, como intelectual (já que recusa a condição de operador), filosofar à altura de seu tempo. E isto, no seu modo de entender, significa aprimorar um corpus filosófico que ajude o Presidente a governar, demonstrando "logicamente" que a via trilhada pela nata do regime é de fato a expressão conforme da racionalidade contemporânea (cabe a pergunta: excluir desta esfera racional de Primeiro Mundo o coronelato que até o momento nunca lhe faltou, ao governo, será mera descortesia ou eclipse do golpe de vista lógico? Mas deixa pra lá), e que, por via de consequência, esta demonstração não será consistente se desconsiderar os desafios da lógica contemporânea. Agora, se isto está em linha com o ISEB, que levou bomba na USP há trinta e cinco anos, e voltou a apanhar na década de 70, cabe ao professor aqui explicar, já que a lebre é de sua exclusiva responsabilidade.

PA - Pode deixar que eu me viro com o infalível sim e não, que um filósofo famoso imortalizou numa fórmula até hoje inédita, o ainda mais infalível, o inexpugnável sim do não e não do sim. Só que antes eu acharia conveniente discutir um pouco a sua observação anterior.

MEC - Mas eu pensei que se tratava de pura implicância da Iná...

PA - Por isso mesmo. Não é que eu discorde. Pelo contrário, acho de fato, como recomenda o supracitado dialético, que se deve procurar o mesmo no outro, e vice-versa, mas acontece que estou proibido de levar pra casa a provocação por uma, ou melhor, duas razões muito simples. Primeiro, não penso, nem posso, renegar minha condição de filho bastardo do marxismo ocidental uspiano, ao qual recentemente o insuspeito Roberto (Schwarz) acrescentou um outro epíteto comprometedor, a saber: industrializante. É verdade também que alinho atualmente com os desajustados do mesmo Partido Intelectual, hoje majoritariamente no poder (pelo menos assim imaginam enquanto vão operando por conta dessa fantasia). Mais precisamente, desembarquei anteontem desse futuro bloco dos ajustados (aos novos mapas cognitivos de que falava a professora mais atrás). Estou condenado, portanto, a uma espécie de balanço permanente, a pagar a conta; a Iná sabe muito bem disso e muito mais. Segundo, não posso nem devo abrir mão das mais notórias discrepâncias entre os dois modelos de interpretação do Brasil, sobretudo em relação ao que prevalecia nos meios de esquerda antes de 64. Não posso deixar de destacar a originalidade da explicação das idiossincrasias nacionais dada pelo marxismo ocidental uspiano, caso contrário perderia metade da graça, se não toda, o amálgama em que me enredei entre 75 e 83, em parte por ignorância, em parte tentado pelo demônio da analogia, e do qual ainda espero em futuro próximo extrair alguma coisa que preste (aliás, razão de ser de toda esta conversa autofalante) se revisto com os olhos de hoje. Ora, à vista do desfecho que todos conhecemos, ou melhor pressentimos, pois de fato conhecemos apenas o prólogo pelo qual ninguém esperava - expoentes do tal marxismo ocidental brasileiro encabeçando uma coalizão tal que lança uma luz retrospectiva nova sobre a notável continuidade da dominação de classe no Brasil -, entendo a observação da Iná como uma sugestão digamos 
clássica: a de reconsiderar todo esse imbroglio ideológico em que estamos metidos (menos a Iná, é claro, pois essa encrenca não é a dela) pelo prisma menos autocomplacente de uma história intelectual materialista, movida portanto a autoengano, do ângulo portanto de um processo ziguezagueando às costas do Partido Intelectual, baralhando ideias e programas, sejam eles cepalino-desenvolvimentistas, comunistas heterodoxos, dependentistas de todos os matizes, ou agora produtivistas (liberais ou sistêmico-competitivos) e sua contraparte por enquanto apenas crítica (pouco se sabe que forma tomará se algum dia se tornar positiva), no caso, da novíssima dependência travestida na roupagem apologética da mutação genética do capitalismo global.

Agora, enquanto a Dona Iná destilava o seu veneno, enfiando todos os gatos no mesmo saco, conhecendo minhas simpatias e dúvidas de toda ordem, eu ia pensando por mim mesmo num jeito de lhe dar razão, a modo de modesta contribuição preliminar para essa história materialista das nossas famílias intelectuais progressistas e os passa-moleques que invariavelmente acabam levando do capital e suas personae locais. Dito de outro modo, e abreviadamente, pois a hora do tratamento explícito deste nó ainda não chegou, veria o problema mais ou menos assim: a reviravolta atual deixa, sem dúvida, à mostra o caráter afirmativo da Teoria da Dependência, mas isto não desmente o acerto do seu diagnóstico anterior acerca das razões explicativas da natureza anômala do desenvolvimento capitalista num país periférico como o Brasil, nem desmente sua superioridade analítica (não direi política, mesmo levando-se em conta a possível clarividência com que se tenha deixado cooptar pela coalizão conservadora que dá as cartas neste país desde o fim da República Ve- lha) sobre os esquemas anteriores (e não só a 64, pois ainda eram mobilizados nos anos 70) que ainda continuavam de algum modo, guardadas todas as nuances, atrelados à conceituação clássica em torno de categorias históricas como burguesia nacional, imperialismo, revolução pelo alto, etc., camisa de força que no entanto compensou a dita inferioridade analítica ao poder fazer economia de outras tantas ilusões, abundantes no outro lado, acerca da "democracia" em capitalismos periféricos.

Precisaremos então atinar com a natureza do aparato econômico-institucional que deu suporte ao longo ciclo daquela coalizão conservadora, sob cuja égide, é bom não esquecer, completou-se a matriz industrial do Brasil, complexo ao encontro do qual acabou se dirigindo o marxismo industrializante e sua intuição original do Brasil, mas não o outro, que por teimosia ou cegueira para o moderno, via apesar dos pesares no passo histórico em questão a perpetuação internacionalizada da mesma autocracia burguesa de sempre. Se dermos com essa corrente subterrânea de longa duração, a saber, para revelar logo o nosso pequeno segredo de Polichinelo, o Estado Desenvolvimentista Brasileiro, cuja Economia Política o José Luiz Fiori me parece que foi o primeiro a decifrar, renovando inteiramente o assunto (nada a ver com as trivialidades que correm mundo a respeito de sua crise de esgotamento, fim do modelo de substituição de importações, etc.), estaremos talvez em condições de apreciar melhor o lugar imaginário das várias formações ideológicas rivais de que estávamos falando.

ICC - Não digo que não, nem sei se acompanhei bem seu raciocínio, ou promessa dele para mais tarde. De minha parte, não estava complicando tanto. Só estava lembrando 
o óbvio da luta de classes, coisinhas rudimentares para a banda bolchevique. O meu time nunca foi escalado em nenhum Partido Intelectual ou coisa que o valha.

PA - Pois então voltemos ao mundinho filosófico, e ao atrevimento de sugerir algum laço de família entre o uspiano Giannotti e o isebiano Álvaro Vieira Pinto. Em comum, absolutamente nada. Mesmo assim, insisto: ao formular a pergunta "por que filósofo?", obviamente subentendido no Brasil dos anos 70, mas sobretudo ao dar a resposta que deu, Giannotti de certo modo, soubesse ou não, pouco importa, reatava com um impulso antigo (do qual já falamos em parte, a propósito do senso de missão do intelectual brasileiro) só que com meios historicamente rifados. E nisto repetia o infeliz isebiano, que outra coisa não pretendeu nos tempos da miragem, com algum apoio na realidade, do capitalismo autossustentado num espaço econômico nacionalmente protegido. E, situacionista por situacionista, um foi e o outro acabou virando.

Vejamos o primeiro, aliás também ele um homem que conhecia o seu métier, excelente professor de Filosofia Antiga e Epistemologia, além do mais tão atualizado como qualquer paulista. Sabe-se lá que parafuso a menos, ou a mais, levou-o a aceitar o convite do ISEB e se tornar o filósofo número um da batalha pelo desenvolvimento nacional. Aqui o primeiro curto-circuito para uma sensibilidade uspiana delicada: como juntar duas coisas que em princípio hurlent d'être ensemble (no nosso caso, em francês fica melhor)? Simplesmente movido por um instinto intelectual mais apurado que o nosso, sem prejuízo do posterior descarrilamento. Não sei se o pacato professor da Universidade Nacional já era dessa opinião ou deixou-se impregnar por ela, apenas inaugurada a fase isebiana. $\mathrm{O}$ fato é que achava que a filosofia não valeria dois tostões de mel coado caso não contribuísse de algum modo (de preferência de modo eminente) para tirar o povo brasileiro da apatia em que vivia, arrancá-lo do mutismo em que vivia apartado da pequena estirpe dos homens cultos, cujo fardo redobrava à vista da responsabilidade de eliminar esse fosso escandaloso. Em todos os sentidos, portanto, a superação do subdesenvolvimento era uma questão de consciência. Antes de sorrir é bom não esquecer que com isso confrontava a sobrevivência da filosofia como atividade relevante com o circuito fechado do subdesenvolvimento, só que em vez de extrair as consequências pertinentes dessa marca cruel, emprestou-lhe uma dimensão positiva de alavanca doutrinária, e por aí se extraviou de vez. Ficava então estabelecido de saída que a marcha do processo brasileiro varia de acordo com o grau de consciência que se tenha dele. À cata de um instrumento capaz de revelar a consciência a ela mesma, elevando-a do torpor inicial à plena coincidência consigo mesma, não é difícil presumir que o encontrará no conjunto de conceitos lógicos e de estruturas de ideias que só a filosofia é capaz de fornecer. Contraprova, aliás, inverificável: o atraso em que então se encontrava a consciência nacional se explica em última instância pela ausência entre nós de uma cultura filosófica consistente (de cujo nascimento é claro não chega a dizer quando foi lavrada a certidão de nascença). Enfim, malgrado nossa tradição nada negligenciável de explicação histórica e social da realidade brasileira, não daremos um passo na referida superação do subdesenvolvimento sem a correspondente concepção universalizadora para além daquelas visões parciais do saber em suma positivo e finito, a que se deve o ponto de vista do infinito instaurado pela filosofia. 
Segue-se demonstração filosófica do teorema básico segundo o qual não há desenvolvimento sem uma ideologia do desenvolvimento nacional. Mal enunciado, abria-se a porteira para o coquetel do momento: muita fenomenologia alemã da consciência, existencialismo, projetos e mais projetos, etc. É bom notar que a fraseologia em seu momento propositivo estava toda ela decalcada na filosofia, digamos, pós-epistemológica, se nos lembrarmos das coordenadas alemãs e francesas dessa transformação da filosofia, e sobretudo dos seus limites. De qualquer modo, a filosofia universitária estrita e suas exigências eram atropeladas pelo sentimento de urgência que animava a fraseologia do momento, algaravia que Gérard Lebrun, recém chegado ao Brasil em 1960, demolirá mobilizando a máquina de guerra que o incipiente estruturalismo francês despachará contra a agonizante fenomenologia: como Lévi-Strauss acabara de desbancar Sartre, também ficava fora de combate (a partir de 64, efetivamente) a arrevesada consciência filosófica da realidade nacional que por um momento encarnara no Rio de Janeiro. Pois juntar filosofia e visão sinótica onde se podem descortinar os fins da sociedade nacional, era tudo o que um uspiano, sobretudo à maneira mais sensitiva do nosso amigo Bento Prado, jamais pensaria voltar a encontrar pela frente, restos de um passado de empenho (louvável, é claro) doutrinário que se imaginava enterrado e bem enterrado. Mas onde afinal o desatino do Prof. Vieira Pinto? (Sobretudo não esquecer de contrapô-lo ao nosso rigoroso raquitismo naquela quadra decisiva da vida nacional, e não só nela).

MEC - Posso responder? Não é tão difícil assim, de tanto que você já bateu nessa tecla. Digamos: ele disparatou por fazer a coisa certa com os meios errados. Como ele se converteu ao nacional-desenvolvimentismo, posso deduzir que ele deve ter começado a valorizar o interesse intelectual pela realidade brasileira, uma constante em nossa vida mental, que ganhou novo alento a partir de 30 e imagino que se intensificou pela descoberta dramática do subdesenvolvimento, coisa que todo mundo sabe e os filósofos, por definição, ignoram. Não sei até onde iam os conhecimentos do nosso homem, mas alguma coisa devia saber, já que o ISEB era multidisciplinar, como se diz nessa horrorosa terminologia de hoje.

PA - Não é impossível que tenha aprendido alguma coisa com o Guerreiro Ramos. Aliás, diga-se de passagem, pioneiro nessa matéria. Refiro-me à disciplina indecisa renascida naqueles inícios dos 70 , a história a sério das ideias políticas no Brasil. Ao contrário da sociologia uspiana (entendamos, Florestan Fernandes e assistentes), Guerreiro Ramos não descartou sumariamente a tradição ensaística anterior, desqualificada pelos universitários paulistas com a pecha de ensaísmo anticientífico. Pelo contrário (e aqui começa a derrapar), chegou a sustentar que a formulação sociológica cientificamente pertinente do interesse nacional pressupunha uma espécie de acumulação prévia do que ele mesmo denominava esforços de teorização da realidade brasileira politicamente orientados, algo como um progresso da consciência na direção justamente daquela visão sinótica reivindicada pela filosofia em virtude de seu ponto de vista infinito (segundo Vieira Pinto ou Husserl, tanto faz, como espero ter dado a entender), mas que o Guerreiro Ramos julgava ser apanágio de uma intelligentsia sem distinção de disciplina científica, flutuando livremente acima das divisões de classe do Brasil velho, senhorial. Consta que foi dos primeiros a 
redescobrir, ainda nos anos 50, os críticos autoritários da Primeira República.

MEC - Até eu que estou chegando agora dou conta de continuar! Posso? Não sei se por instinto ou não, acabou atribuindo à filosofia, com a maior naturalidade do mundo (não se trata mesmo de um golpe de vista de abrangência universal?), a condição de peça fundamental (fundacionismo, professor?) na formação da consciência nacional, porque sem ela não pode haver desenvolvimento no sentido superlativo do termo, tal como se entendia antes de 64. Para falar outra vez como Antonio Candido, tal qual a literatura em sua fase de incorporação. O erro então foi achar que caberia à filosofia prolongar essa tarefa até a consumação utópica da emancipação nacional. Isso, por duas razões que já estamos cansadas de saber, depois de horas e horas de mal disfarçada aula. Primeiro, porque filosofia no Brasil não estava com essa bola toda; era muita, e ingênua, pretensão. Segundo, porque, ainda que estivesse funcionando a contento conforme os padrões europeus, fazia tempo que o gênero filosofia como tal tinha perdido precisamente essa capacidade de "figuração" (para empregar a terminologia vista em classe) da totalidade histórica presente, de apresentação exclusivamente à base do aparato conceitual herdado, e muito a propósito remanejado, da tradição filosófica. E o fato dele ter pilhado as filosofias pós-epistemológicas conta a favor do interesse histórico daquele erro monumental. Monumental sim! Deus me livre! 800 páginas em dois volumes!

ICC - Antes que o Paulo tire o chapéu e declare: eu não conseguiria resumir melhor, já vou passando a bola pra frente e perguntando pelo Giannotti. Para adiantar o expedien- te, e poupar o professor, evitando que ele repita o já dito numa entrevista, se não me engano para o Ricardo Musse, no Estadão, a pretexto do livro sobre a filosofia uspiana, posso imaginar o seguinte prólogo, se conheço bem a cabeça aqui do suplicante e se é realmente fato que na dele outros também estão autorizados a pensar. A cassação de 69 e logo após a fundação do CEBRAP, num certo sentido caíram do céu, desobrigando o filósofo de tocar o serviço miúdo de uma repartição intelectual. Por outro lado, também veio na hora certa (sem fazer humor negro, espero que me entendam, pois não suporto brincadeiras com as barbaridades da ditadura): no momento em que afinal se podia dizer que o desejo dos paulistas de ter uma filosofia se realizara. E, uma vez completa a formação, chegara a hora de dar um outro passo à frente, o primeiro da maioridade enfim alcançada e que a filosofia não podia ficar devendo, sobretudo depois que a ciência social já dera o seu recado na década anterior (Teoria da Dependência na versão uspiana, vista como prolongamento coerente da linha anterior de interpretação da formação colonial-escravista sob a égide do capitalismo moderno), sem falar, é óbvio, na Economia Política do Celso Furtado, cuja estrela no entanto, como se sabe, começaria a declinar uma década depois. No CEBRAP voltou a reunir-se uma fração importante do antigo Seminário Marx, o que de certo modo era decisivo para empurrar o Giannotti à luta, no caso, o estudo das formas da sociabilidade capitalista (para falar como o nosso personagem de agora), no plano superior da especulação filosófica. Aproveito aliás a ocasião para dar um palpite: acho que muito da reviravolta do Giannotti, de uns anos para cá, se explica pelo declínio paralelo de seu grupo. Bem entendido: declínio rumo ao alto, cuesta arriba, às altas esferas nas quais se encastelaram, a 
meu ver desde 82, com o Governo Montoro, quando então deixaram definitivamente de pensar (estou dando de barato que o faziam antes) para operar, sans phrase, ou muito pouco, e de preferência lero-lero social-democrata (na mais "comunicativa" das hipóteses). Mas também se explica pelo nível de exigência mais rebaixada, ou mais apurada, conforme o gosto, pois estou me referindo à sua entourage mais jovem e especializada, sob medida para sancionar sua carreira filosófica como sendo a de um profissional da lógica. Daí a atual divisão de trabalho que faz com que ele procure legitimar, de modo tão estabanado, com argumentos de filosofia transcendental, o reboquismo do Planalto no mainstream em que se celebra o novo espírito do capitalismo, como costuma dizer o Presidente, reformando Weber.

Mas isso era só um parêntese, pra chatear mesmo. Volto aos anos 70, sempre confiando em que estou reproduzindo o que achei ao pensar em cabeça alheia (mas não era isso o que Kant chamava de largueza de espírito, apanágio da faculdade de julgar?). Pois então, nessas circunstâncias, era inevitável que, uma vez no CEBRAP, nosso autor se perguntasse: e agora, o que fazer? (Vou indo bem, professor? Onde você começa e eu termino? Tanto faz? Então vamos em frente.) A pergunta "o que fazer?" parece ter sido respondida em dois tempos: primeiro, pelo estudo sistemático das grandes teorias sociológicas com vistas a uma teoria geral da sociedade de corte a um tempo ontológico e dialético, o que de fato foi feito e publicado na forma de livro no começo de 83, e isto também porque não era mais possível retomar nos velhos moldes a leitura do Capital. Mas, sendo assim, salvo textos ocasionais sobre a noção de modo de produção para uso e abuso dos cientistas sociais, como identificar o lugar do filósofo de profissão? Como prolongar (este é que é o nó) e legitimar o antigo poder de fiscalização exercido pela filosofia?

PA - Posso interromper por dois minutos? Se me fosse refeita a pergunta, aliás formulada por você mesma lá atrás, acerca do assim chamado "materialismo interdisciplinar" dos frankfurtianos dos anos 30: por que pensar nesta circunstância e tudo o que daí decorre a propósito da atuação do Giannotti no grupo do Capital e depois no CEBRAP? Eu acho que agora seria o lugar certo para esse tipo de cotejo, coisa que no entanto não farei para não espichar demais o seu requisitório. Mesmo assim, acho que alguma coisinha talvez precise ser dita, sempre na intenção de compreender o drama da consciência filosófica profissional quando confrontada com as exigências da vida nacional (será preciso lembrar? Jamais entendida em chave nacionalista ou outro emparedamento qualquer), drama agravado por se tratar de uma leitura filosófica do Capital com nítida intenção oposicionista, não obstante o ambiente acadêmico de origem, e o fato também relevante de que as especialidades requeridas pela natureza do objeto, e antes concentradas num autor só em cuja experiência se cristalizara uma espécie de via de acesso coletiva à integralidade do processo, se apresentavam agora na forma de especializações científicas institucionalizadas. E, se Lukács tinha razão, coisa incompatível com a visada mesma requerida pela "totalidade". Ora, o interesse nisso tudo é que com este último estado de coisas os frankfurtianos também se confrontaram, daí o lembrete, além do mais porque estamos diante de dois capítulos comparáveis do mesmo marxismo ocidental. Mais exatamente, no caso alemão, o segundo capítulo, se é fato que fica combinado que o primeiro começou com História e consciência de classe. 
A propósito, ainda, duas diferenças assinaladas recentemente pelo Roberto Schwarz: os frankfurtianos não estavam minimamente empenhados em achar saídas nacionais com a chave teórico-política do marxismo em mãos, ao contrário dos brasileiros, a bem dizer condenados a essa tarefa inglória pela condição colonial-periférica de que partiam e procuravam decifrar. Já esse déficit, vistas as coisas do lado de cá, poderia dar uma ideia do descaso por estas bandas pela crítica das formas contemporâneas da alienação, a outra metade da crítica marxista do mundo do Capital, análise do fetichismo da mercadoria que a bem dizer impulsionou o núcleo mais avançado do trabalho dos frankfurtianos, eclipse que explica muita coisa da capitulação subsequente que arrematou o capítulo brasileiro. E também, pelo caminho, o que está na berlinda agora, as relações da filosofia profissional com a cultura viva, cujos ritos de passagem o marxismo em princípio deveria envenenar depois de explicar. (Em tempo: sou eu que estou empregando o termo capitulação, não o Roberto. Acho mesmo que não é a melhor palavra, pensando bem, excessiva, visto que os vínculos do grupo com os de baixo não eram propriamente orgânicos, eram mais da ordem da solidariedade moral lastreada na virtualidade política de uma vida estudiosa intransigente. Mas se tomarmos capitulação do ângulo da cultura teórica e sua carga negativa, não retiro. E imagino que nem o Roberto). Dito isto...

MEC - O quê, exatamente?

PA - Como, o quê?

MEC - O que, mais precisamente, ficou dito?
PA - Digamos então, confusamente sugerido: que seria do maior interesse um estudo comparado desses dois episódios do marxismo ocidental, o frankfurtiano e o brasileiro-uspiano, na falta de melhor denominação. Outra coisa, antes que eu me esqueça, que me ocorreu agora e acho que dá o que pensar, sobretudo pensando no meu caso, quero dizer, na minha falsa germanística de anos atrás: como lembrado pelo Roberto Schwarz, nem Marx nem os frankfurtianos de ontem, ou qualquer outro intelectual alemão do contra, não necessariamente marxista, como o Enzensberger, ou pela metade, como o Robert Kurz, estavam interessados em encontrar uma saída específica para a Alemanha, fosse ela socialista ou meramente burguesa-ocidental, quando expunham a patologia planetária do capitalismo, ao contrário dos brasileiros perseguidos pela missão atávica de superação do subdesenvolvimento. Ora, estava pensando depois de citar o Lukács dos anos 20 como o inventor paradoxal do marxismo ocidental, e o paradoxo se deve ao fato de estar alinhando com uma Revolução até então vencedora: pois não é que o Lukács, a partir dos anos 30, se voltará cada vez mais para o estudo de um caso nacional? Está claro que não é um caso qualquer, a saber, o alemão. É óbvio que não de um ponto de vista historiográfico trivial, mas de um ângulo a um tempo cultural e político, de um lado uma constelação singular de capitalismo retardatário e extrapolação teórica ilimitada (à esquerda e à direita), espécie de câmara de decantação da civilização burguesa de saída indeterminada e por isso mesmo exigindo, de outro lado, diagnósticos práticos envolvendo esse caso de consciência nacional infeliz na trama social da luta de classes, por sua vez arena de esclarecimento das posições em jogo e critério de juízo crítico, o conjunto implicando portanto nossa velha conhecida, a 
procura de saídas nacionais, agora explicitamente comprometida com a democracia (periodicamente abortada desde a Guerra Camponesa) e o socialismo (já que a premissa da industrialização estava concluída). Com ênfase menor, é esse o ponto de vista predominante no estudo da literatura russa do oitocentos, ou da implicação recíproca de narração e democracia pequeno-burguesa na Suíça de Gottfried Keller, para dar um exemplo nacional de porte médio (mas o ensaio respectivo é notável), ponto de vista além do mais comparatista, só que na acepção materialista da operação - aqui comparação é razão, e como! - pois o termo de comparação obrigatório é a solução francesa (ou inglesa) para o filtro cultural da luta de classes; como explicar essa mudança de ótica?

A primeira coisa que me ocorre, como a todo mundo, suponho, atende pelo nome fatídico "socialismo num só país", nem de longe um problema exclusivamente doméstico. A segunda, e fico nela, não sei se da ordem da consequência ou do recurso compensatório, tem a ver com a valorização da cultura burguesa do oitocentos, e necessariamente sua correspondente diversificação nacional, maneira de restabelecer a continuidade do progresso civilizatório depois do desfecho nazi da decadência burguesa que por sinal remonta ao período imperialista daquele mesmo oitocentos. Creio que isto deve valer também para o Gramsci e sua dedicação de vida inteira ao nó da inércia italiana. Mas já não sei, explorando um pouco mais esse veio do marxismo ocidental que apresenta um evidente parentesco com o nosso, não sei se isso ainda vale, por exemplo, para um capítulo bem mais recente desse périplo como o de Perry Anderson, também interessado numa renovação teórica do marxismo local em linha com uma revisão da história inglesa desde a Guerra Civil e a inci- dência do compromisso conservador que a enquadrou sobre a cultura britânica e o seu conformismo de nascença, sobretudo se comparado ao radicalismo da tradição jacobina no continente. Tudo isso para lembrar que o confinamento nacional do nosso marxismo ocidental não está em má companhia, que integra inclusive um quadro mais amplo de um processo mundial desigualmente particularizado em suas manifestações locais que, por isso mesmo, formam um sistema, com o qual acabei me metendo (é a palavra certa para um camarada tão despreparado, como vimos), empurrado pela sensação mal explicada do nada a fazer filosófico.

Mas voltando ao exato contrário daquele mal estar na cultura filosófica uspiana, o enérgico à vontade do meu professor Giannotti e, como logo a Iná relembrará, compenetradíssimo ao longo dos anos 70 em sacudir a poeira filológica dos seus colegas e antigos alunos. Duas palavras então sobre o nosso desencontro com os frankfurtianos de entreguerras (e do imediato pós-guerra, quando fecham de uma vez seu diagnóstico sobre o fim de linha da civilização do capital) que o Roberto Schwarz já começou a explicar. Repito: lembrando que um juízo tão inapelável sobre a inviabilidade civilizatória do capitalismo só poderia cair mal, uma impertinência incompreensível por parte de um marxismo construtivo mais interessado em industrializar um país colonial, que precisava apostar portanto numa certa normalidade capitalista com fôlego suficiente para alcançar aquela meta (por meio até de uma ruptura revolucionária, se servisse aos mesmos propósitos de saída nacional). E mais: agravando o desencontro, aquela versão materialista original do nosso conflito de passagem básico Colônia/Nação contava a seu favor com um fortíssimo apoio na realidade, aparência tão solida- 
mente ancorada nos fatos que deveria mesmo empurrar os ditos frankfurtianos históricos ao plano inferior do grã-finismo metodológico, da má vontade estetizante, do absenteísmo ornamental, perfumaria hermética, etc., etc. Se já disse, e não me importo de repetir, eles foram derrubados e por isso mesmo eram considerados ilegiveis (uma prosa armada intencionalmente para estar à altura de um impasse histórico de tirar o fôlego não poderia deixar de afugentar leitores em qualquer parte do mundo confrontados com um retrato sem retoques da própria alienação, em particular brasileiros, positivamente engajados e formados numa tradição intelectual alérgica à complexidade conceitual de construção literariamente exigente de um argumento) pela evidência palmar de que o famigerado imperialismo responsável por nossa antiga condição primário-exportadora estava não obstante abrindo caminho para a industrialização na periferia, enquanto no centro o mesmo grande capital aceitava o mal menor do Welfare. Mesmo com o risco de mais repetição, não posso deixar de encadear: quer dizer, na raiz desse desencontro, a confirmação quotidiana de que estávamos certos. O desmentido que os trinta anos de consenso keynesiano não cessou de aplicar em tempo integral ao humor negro filosófico dos frankfurtianos clássicos, ministrando uma prova irrecusável de que a assim chamada crítica da razão instrumental, além do mais conceitualmente inclassificável, não dispensa ninguém da oposição, onde afinal nos encontrávamos todos, de encarar a domesticação do bicho pelo ângulo explicativo da Economia Política; acontece que os desacreditados pessimistas culturais tinham, sim, feito um diagnóstico do referido ângulo de ataque, formulado em pleno coração imperial-americano do sistema, e que poderia ser grosseiramente resumido mais ou menos as- sim: mesmo na sua idade pós-liberal o capitalismo continuava igual a si mesmo, a lei do valor funcionando a todo vapor, o sistema sempre à beira do colapso como queriam os clássicos e, como o demonstram duas guerras mundiais imperialistas, a maior depressão da história econômica moderna, e sobretudo a fuga para a frente fascista. Tudo isso demonstra, enfim, que a grande contradição continua aí, só que na forma de uma simbiose substitutiva entre as forças produtivas e as relações sociais de produção, o que quer dizer que o sistema só sobrevive com ditadura (eleições são um procedimento de gerenciamento interno) e, como finalmente revelaram o laboratório nazi da sociedade de massa e a posterior imigração americana, a saber, nenhuma diferença substantiva entre a coreografia encantatória de um Goebbels e uma campanha publicitária da Unilever (quem imaginar que eles estavam exagerando é só ver a Leni Riefensthal filmando um comício nazista). Violência política organizada na forma do Estado e indústria cultural convergem ou se alternam ou se compensam mutuamente, desde que a mercadoria seja entregue (como não entregou a dita cuja, a economia stalinista de mercado entrou em colapso), na tarefa de assegurar a adesão das populações enquadradas pela síntese social da relação de troca mercantilizada à engrenagem da acumulação e da valorização. Ora, a esta impertinência a que estou dando feição bárbara, a temeridade de arriscar um diagnóstico fechado do capitalismo, apanhado num momento de explosão dos mecanismos de mercado (favor comparar o diagnóstico deles com outros de igual envergadura e rigorosamente contemporâneos, como os de Schumpeter e Polanyi), aqueles senhores (que segundo nosso amigo Giannotti ignoravam o teorema de Gödel e não tinham notado que Wittgenstein mudara de fase) acrescentavam 
a petulância de não se deixarem impressionar pelo sucesso crescente do Estado keynesiano. Continuaram batendo na mesma tecla da administração total sob a fachada do crescimento econômico e da trégua social, a lembrar que a tendência ao colapso estava inteirinha aí, que o dique do bem-estar é exceção e não regra, a aparência social de que se reveste a contratendência que apenas barra o caminho mas não extirpa nada na direção das tendências profundas e mais sinistras do famigerado sujeito-automático. Cúmulo da insolência: desmoralizados durante os trinta anos gloriosos que durou a aparência keynesiana do capitalismo organizado, estão eles aí de volta (lembrete: desde meados dos anos 30 não tinham mais ilusões quanto ao caráter da acumulação primitiva soviética, envolvendo inclusive colonização interna e trabalho escravo, nem quanto ao futuro do movimento operário, que poderia derreter como neve ao sol sem comprometer a teoria do valor e a realidade escabrosa da exploração agravada, pela falta de um macro-sujeito inclusive; sujeito, só o outro, o automático), embora todos mortos, e o que é mais interessante, não trazendo no bolso do colete nenhuma solução (seja dito em favor da sobriedade teórica e política deles), menos do que nunca alguma orientação para a reforma do capitalismo mundializado e de novo reconciliado com o seu futuro devastador. Convenhamos, dose de elefante, não só para o nosso marxismo uspiano como também para qualquer outra variante, digamos não-ocidental e anti-stalinista, aqui ou na Europa. Menos para o Roberto (Schwarz), que resolveu finalmente levantar a lebre do cotejo que está nos interessando agora e de cuja deixa estou abusando um pouco. Não tenho dúvida de que foi a leitura do Kurz em fins de 91 que o decidiu a pôr no papel a ressalva que arremata o seu depoimento sobre o grupo do Capital.
E já que entramos por aí, continuo mais um pouco, se não houver objeções. Acho que acertando bem mais do que errando (quando não divagando sobre "razão sensível", economia natural microeletrônica, etc.) pelo menos seus achados são bem mais animadores do que os seus desacertos podem ser comprometedores, o fato é que o alemão descoberto pelo Roberto acabou repondo em movimento a outra metade submersa dos esquemas da velha guarda frankfurtiana, ainda que sem nenhuma intenção deliberada a respeito. Pelo contrário, em duas ou três ocasiões, se me lembro bem, chega a fazer restrições às posições frankfurtianas no fim da guerra (posições que eles nem se deram mais ao trabalho de modificar ou justificar à vista dos trinta gloriosos anos subsequentes, como já disse): a seu ver, Pollock, Horkheimer e Cia. teriam sido vítimas da predominância ilusória da função econômica reguladora do Estado num período que conheceu tanto a economia de comando soviética quanto o New Deal e o planejamento econômico do fascismo alemão, imaginando a perpetuação terminal desse momento estatista (na verdade alternando com o monetarista segundo o movimento ondulatório que para o nosso autor define o processo contraditório da modernidade burguesa). Assim, enquanto o marxismo ortodoxo acreditava que a tendência estatista representava um polo antagônico encarregado de suprimir o modo de produção de mercadorias, do qual na verdade era um elemento constitutivo e congênito (sem Estado não haveria forma-mercadoria), os heterodoxos do Instituto de Pesquisa Social simplesmente mudaram o sinal deste mesmo movimento rumo à sociedade totalmente administrada, só que fundada no capital, cujas contradições o Estado, necessariamente autoritário, pouco importando sua fachada política do momento, teria por função 
congelar numa falsa supressão do mecanismo explosivo do trabalho abstrato organizado na forma de empresa, enfim, uma espécie de normalidade negativa por assim dizer, como se a alienação pudesse se reproduzir indefinidamente e sem atritos. Se não me enganei, podemos ver que o Kurz curiosamente também engoliu o lugar comum da história frankfurtiana congelada, quando a contradição estava simplesmente hibernando por força daquele represamento de que estávamos falando, que apenas bloqueia as tendências fundamentais sem removê-las.

Mas voltemos à lebre levantada pelo Roberto Schwarz. (Para que se tenha alguma noção de onde estamos, vou abatendo os parênteses: no capítulo filosofia profissional e divisão social do trabalho intelectual, por onde andava o Giannotti de meados dos anos 70; marxismo ocidental cá e lá, comparar o quefazer do filósofo nos dois grupos, Instituto de Pesquisa Social dos anos 30 no que tange à natureza e lugar da filosofia enquanto disciplina implicada pelo tal "materialismo interdisciplinar" enquanto fé de ofício do grupo, mais adiante a virada habermasiana, por aqui, Seminário do Capital, CEBRAP, etc. e a correspondente evolução do nosso número 1 filosófico; comparação baseada num desencontro, este último repertoriado recentemente pelo Roberto, só que, para poder voltar ao Giannotti neste cenário comparativo, achei que o caminho ficaria mais interessante se considerássemos por dois minutos a curiosa convivência de um frankfurtiano de carteirinha e um sócio fundador do marxismo ocidental uspiano numa só e mesma pessoa, só que aqui mais com menos não dá zero, longe disso). Então, de novo os dois Robertos, o nosso e o alemão. Preciso, entretanto, lembrar que o nosso não precisou do outro para começar a organizar as restrições que já conhecemos à árvore genealógica da qual descende. Me lembro bem que não é de ontem que vinha reparando no preço muito alto que o dito marxismo do círculo do Capital acabaria pagando pelo seu descaso, para dizer o menos, pelos problemas armados pela arte contemporânea, a começar pelo modernismo brasileiro: sempre o encafifou que uma intuição tão original do Brasil como a que resolvera o imbroglio escravidão/ capitalismo pudesse dar as costas à dimensão de conhecimento inerente à redescoberta modernista do país. Como leitor dos frankfurtianos (até onde eu sei, um dos primeiros e até hoje um dos mais inventivos, tanto é que até hoje evitou escrever diretamente sobre eles), não lhe passava pela cabeça que teoria estética e crítica social não devessem convergir; fatalmente, na ausência da faculdade problematizadora da primeira, a segunda vai embotando até se anular. Não deu outra, e não é de hoje, não estou pensando na conjuntura do momento, o ajuste do atual establishment intelectual já vem de longe, ou melhor, não lhes custou nada, nenhuma adaptação dolorosa, uma reconversão sem anestesia. Se é verdade, como diz o Roberto e não eu, que não era pequena a dose de conformismo embutida num tipo de marxismo em linha com os anos de desenvolvimentismo que o viram nascer, mais interessado nos impasses da industrialização brasileira do que na lógica da mercadoria e a normalização da barbárie que ela sustenta, não espanta que se deixe levar na conversa de uma nova onda schumpeteriana de destruições criativas, que embarque na canoa furada da competitividade, determinismo tecnológico e outras miragens produtivistas-globalizantes. Aliás, seguindo a própria distinção do Roberto (de um lado, marxismo industrializante e, do outro, desinteresse pela crítica de Marx ao fetichismo da mercadoria), sendo a lógica cultural (para falar como o 
Jameson) uma das chaves da reprodução do capitalismo-cassino de hoje, não pode mesmo surpreender a apologética produtivista em que se vai encalacrando esse mesmo progressivismo marxista tão inocentemente cego para o lado degradante da mercantilização e industrialização da cultura comandadas por aquela lógica do culturalismo de consumo total.

Seria preciso lembrar que este quadro não comporta exceções? Pelo sim, pelo não, já vou adiantando que o argumento implícito na distinção operada pela ressalva final do Roberto - que por sua vez acabou chegando à formulação atual graças ao impulso decisivo que recebeu, agora sim, da partilha feita por Kurz no interior do marxismo, um lado morto, o marxismo do movimento operário e sua ontologia positiva do trabalho, e o outro lado, este sim, muito vivo e letal, o momento negativo da crítica do fetichismo da mercadoria, nele incluída a regressão cultural e social desentranhada metodicamente pelos frankfurtianos - deveria em princípio alcançar os dissidentes do atual consenso estabilizador liberal-produtivista, que ao se deixarem por sua vez arrastar com idêntica inocência positiva e consumidora pela mesmíssima lógica cultural, cedo ou tarde desembocarão no mesmo beco sem saída nacional e portanto na armadilha ideológica do confronto de modelos, estratégias, etc.

ICC - Mas se é assim, fica difícil evitar a pergunta: por que só agora o Roberto Schwarz, ele mesmo marxista uspiano de primeira hora, pôs essas restrições na roda? Ou então: já que elas não seriam de hoje, como ele conciliou até agora os dois registros? O nosso amigo também será dois, tipo Oswald de Andrade que, como costuma dizer o Antonio Candido, combina pai de família e capeta pau-brasil?
E assim por diante? Se é que estamos todos de acordo em espichar um pouco mais este parêntese sobre o desencontro Frankfurt/São Paulo...

PA - Por mim tudo bem, desde que vocês me ajudem a encontrar o caminho de volta.

MEC - Não me parece prudente...

ICC - Sua traidora!

CR-Ops!

PA - É, pensando bem, também acho perigoso. Melhor voltar rapidinho ao Giannotti dos anos 70 , exigindo dos colegas e ex-alunos que saíssem da história (da filosofia) para entrar na vida, dá para prever que com uma enorme maiúscula filosófica. Mesmo assim, na minha condição de muy fiel escudero, não posso deixar passar a dúvida da Iná (não precisa agradecer) sem ao menos uma ligeira satisfação. Para encurtar, reconheço que não deve ser fácil a vida de um leitor brasileiro de Adorno e Cia., na hipótese, é claro, de um leitor sóbrio o bastante para não se deixar ofuscar pela ideologia não-me-toques da alta cultura humanista, na qual os semi-informados costumam reconhecer o atributo inato de todo mandarim alemão (o pobre Adorno morreria de novo se topasse com os gauchistas que lhe infernizaram os últimos anos de vida travestidos agora de leitores devotos de sua obra, convertida em instrumento de edificação cultural nas mãos de pedagogos e terapeutas de almas raras, falsa contrapartida highbrow da cultura de massa, porém inocentemente rastaquera e igualmente consumista), e suficientemente veterano 
para não encalhar na fase preliminar da assimilação e exposição de um clássico bem digerido, etapa obrigatória mas que não pode virar profissão (tem alemão sobrando no ramo, sem falar nos decalques americanos). Pois bem, mesmo tomadas todas as precauções, não deixa de ser arriscado o dia-a-dia ideológico de um admirador esclarecido de Adorno no Brasil. Tomo o Adorno como exemplo, não só por ser o autor de maior envergadura deles todos, ditos frankfurtianos, mas sobretudo por se encontrar no momento curiosamente na berlinda entre nós, quem diria: de um lado, algo que não havia no meu tempo (bom sinal, aliás), jovens estudiosos de Adorno, uma nova geração muito competente, germanistas de verdade e, no outro corner, Giannotti, um contendor nato, que sempre implicou com Adorno sem ter paciência de ler o homem (cujos parágrafos de fato não são convidativos) e que agora se decidiu, já sabemos por quê: como o nosso filósofo, por amigos e convicções interpostos, se aproximou do poder no bojo de uma coalizão por assim dizer disposta a cavar uma brecha por onde pelo menos uma parte do Brasil tome uma carona no capitalismo que está se mundializando (mas não para todo mundo, é óbvio), deve ter pensado, com toda razão, que lhe competia como membro especulativo da fração ajustada do Partido Intelectual entrar em campo com a missão de desqualificar, com a ênfase metodológica à qual o marxismo uspiano deve tanto, a mais leve insinuação de que o capitalismo continuava o mesmo de sempre, a saber, uma ameaça à vida civilizada no planeta. Falando em nome dos integrados (por pragmatismo ou mudança de paradigma, pouco importa, se a manobra é consistente, o preço cobrado em constrangimentos objetivos vem a ser o mesmo), era de se esperar que espinafrasse o apocalíptico-mor, afinal não pega bem sugerir que as reformas voltadas para o mercado, de cuja racionalidade não se pode duvidar, sem faltar com o decoro epistemológico, estão voltadas para o lado mais sinistro da história contemporânea, sem prejuízo das boas intenções dos operadores intelectualizados da referida coalizão. Só para continuar um pouquinho mais: não é a parte menos divertida nessa Guerra Santa o fato do Giannotti saber perfeitamente que o indigitado mandarim alemão sempre se considerou o último burguês, se é verdade que um intelectual na era do oligopólio mundial é o derradeiro representante daquela classe praticamente extinta, e que portanto não nascerá destas bandas (ou sim?) o ideólogo dos sem-dinheiro, sem-teto, sem-emprego, sem-terra, sem-coisa nenhuma (embora absolutamente modernos, como exigia o poeta). Giannotti sabe disso (nem mesmo se trata de um nostálgico das economias de comando, longe disso), e no entanto ferve-lhe o sangue se alguém por perto fala mal de televisão, torce o nariz para a última temporada lírica no Metropolitan ou não lhe dobrem os joelhos ouvindo Bach, etc., pois o chato que lhe desmancha o prazer por desconfiar da redenção pelo consumo cultural (ou só para chatear, pois o fetichismo não abre exceções), acaba tocando num ponto nevrálgico ao esnobar perfumarias (coisa de que na velha Maria Antonia sociológica era de bom tom "radical" divergir, mas a bijuteria era outra evidentemente), que não são mais quinquilharias, tanto faz se de segunda mão. De um modo ou de outro, como a reprodução do sistema passa agora também pela cultura-em-geral, desde que consumida nos moldes da economia de escopo (mau gosto da escala fordista), trata-se de um ponto de honra e, como tal, intocável, daí a impaciência com o chato adorniano, às vezes improvisado, pois a menor impertinência toma proporções de um atentado à normalidade 
capitalista, miragem sem a qual não se governa, pelo menos com o conforto das legitimações ad hoc (inflação em baixa, reservas em alta, frango e festival internacional de qualquer coisa "estética”). Quem disse que a Teoria Crítica durante a Alemanha de Adenauer desempenhara o triste papel (se é que não passara despercebida) de ornamento crítico de uma época de restauração, não poderia prever que algum dia ela (a velha guarda, Habermas é outro caso, de ornamento moral) ainda prestaria o serviço nada irrelevante de exasperar a má consciência (uma esperança?) dos novos bem pensantes de um país periférico. Mas nem por isso ela torna a vida mais fácil no campo adverso.

Aqui voltamos à dúvida (ou certeza?) da Iná, que ao Roberto perdoaria tudo e muito mais (se fosse preciso), menos a queda por Adorno, de cujo passivo sabemos todos que a professora faria um inventário rigorosamente oposto ao elenco de chateações lógico-estéticas que tanto enfurecem o Giannotti. Em suma, herói dividido, admiradores idem. Para começar bem por baixo, no segundo ou terceiro círculo dos discípulos, volto a me olhar no espelho, um caso trivial de dupla personalidade se não fosse a tranquila inconsciência com que fui levando esse barco de duas proas, e o que se vê? Em 74, ano da primeira grande derrota eleitoral da ditadura, anulei meu voto, coisa compreensível num recém desembarcado de torna viagem de estudos, encharcado de abstrações da década anterior; em 78, vocês se lembram, primeiras greves no ABC e campanha do Fernando Henrique para o Senado (saiu suplente, como planejado), já me considerava base do Partido Intelectual, armado de procuração tácita para ajudar a tirar o país do buraco, sem no entanto alterar antigos hábitos de leitura, tirante é claro o fervor brasilianista contraído fazia pouco. Vem daí o disparate que está nos interessando no momento: continuei a ler Adorno com a intermitente regularidade dos amadores (em tempo: foi o Rober to quem numa tarde de 1965 na livraria Herder pôs nas mãos do jovem primeiro aluno de seu amigo Bento Prado as Minima Moralia, em alemão, que fiquei sem ler até conseguir uma tradução italiana alguns anos depois, iniciação sem efeito imediato, portanto), sem ver nisto o menor empecilho para mergulhar por meu turno no Jordão constitucional, a saber: votei no Montoro, votei no Quércia, votei no Fleury, no Fernando Henrique umas três vezes, votei até no Serra uma vez. Está certo que qualquer leninista realmente existente tiraria de letra o eventual escrúpulo e demonstraria de quebra que continuaria na mesma quem por desencargo de consciência preferisse a porta ao lado, o Partido da Verdadeira Social-Democracia Brasileira (o atual desmanche aparelhista do PT prova que não estou simplesmente maldizendo, além de comprovar, caso necessário, que social-democracia em capitalismo retardatário é voto duplamente piedoso), mas não era bem este o caso do camarada em questão, mais chegado numa Negação e demais coisas de Não do que na indução da demanda agregada, contra a qual aliás nada tinha a opor, pois não eram os marxistas do seu Partido neokeynesianos e desenvolvimentistas, sob pena de inoperância? Mas disto eu pouco sabia, e se soubesse não seria problema, como agora de fato se tornou. E isto, pelo menos no que me concerne, graças justamente ao Roberto Schwarz, do modo como o vimos há pouco levantar a lebre. Por isso, juízo: não me transponham ao meu superior o estado de paródia involuntária em que vivi ultimamente (e ninguém garante que não continue assim), em primeiro lugar porque ele foi o primeiro a enquadrar conceitualmente esse fenômeno central em nossa vida ideológica e, segundo, porque foi 
ele novamente o primeiro a remover o véu de ilusão que encobria o lado afirmativo do nosso marxismo ocidental uspiano. Por que só agora? E como fica daqui pra frente a esquizofrenia herdada do período anterior? De modo que as dúvidas da Iná continuam de pé. De fato, não é nada fácil num país de forte empenho intelectual como o nosso engolir a palavra de ordem adorniana do nichtmitmachen (não participar), por mais variantes que se inventem para evitar os disparates inerentes a qualquer aplicação chapada, nela incluído o artifício inverso de ignorar a interdição expressa do engajamento direto, sem a mediação da forma, que ao anular a positividade do primeiro multiplica indefinidamente os procedimentos da segunda, outra maneira de anunciar que a utopia deixa de ser tal ao se tomarem providências a respeito, que a vida reconciliada quando muito se deixa entrever na imagem negativa que por um momento pode brilhar naquelas obras de arte que souberam renunciar ao seu destino afirmativo. Abreviando: o problema mudaria muito de figura se Adorno não tivesse transposto para o plano discursivo da crítica da sociedade o que ele mesmo demonstrou ser específico, inclusive como ponto de vista privilegiado, da experiência estética contemporânea, experiência negativa é claro. A crise se complica (e para um brasileiro, então, nem se fala) quando eu passo a dizer o seguinte, à vista dos desastres contemporâneos: não participar é a primeiríssima medida a ser tomada se eu não quiser que se reproduza no decurso da vida das ideias a estrutura coisificada do curso do mundo, cujo enigma opressivo eu posso então, e só assim, resolver trazendo para o primeiro plano da consciência desenganada a forma-mercadoria do mundo e os efeitos de sua generalização. A não-participação não garante nada (como o ensaio), mas é pré-condição cujo desrespeito é mortal.
Acontece que o teorema marxista no qual Adorno baseou a sua causa, ao chamar a exploração pelo nome, exige exatamente o contrário como condição de verdade do seu próprio enunciado. É claro que Adorno sabe disso tudo, que se deve ao mundo congelado pelo capital a alienação que cavou um abismo entre teoria e prática, acrescentando porém que as coisas pioraram tanto no capitalismo dos oligopólios que qualquer passo voluntário destinado a cobrir esse rombo não só agrava o divórcio como contribui para a reprodução ampliada desse mesmo sistema unidimensional de positividades, e não é de ontem que ele diz isso, pelo menos desde meados dos anos 30, quando ficou claro que só dava para levar adiante a metade do programa traçado por História e consciência de classe (o núcleo original do que viria a ser o marxismo ocidental), a teoria social da reificação como chave da crítica da ideologia, porém amputada de sua resolução prática, a revolução proletária, desde então também estava rifada qualquer veleidade política de suprir pela organização a mediação de que carecia para rejuntar a crítica à consciência de classe (prática, por definição), de sorte que aos poucos também acabou ficando claro que a única prática seria a da crítica que, sendo um saber negativo, nem que quisesse poderia transmitir o vírus da positividade capitalista para a futura ordem socialista, como de fato estava ocorrendo à vista de todos que acompanhavam a tragédia stalinista. Tudo isso é sabido, mas estou contando assim mesmo porque o Adorno desnorteia muito, pois com a maior inconsequência do mundo, ou consequência, dependendo da dimensão do marxismo sobre a qual as voltas da história fizeram recair a tônica, cancelou o papel de ator principal que cabia de direito à força de trabalho organizada em classe antagônica pelo capital, conservando não obstante tudo o 
mais do marxismo clássico, em primeiro lugar a teoria do valor-trabalho, por que não?

ICC - Tô fora. Não vou nem discutir. Mas prossiga assim mesmo, estou esperando você chegar ao Roberto só para esclarecer aquela duvidazinha. Depois, bola pra frente: por que filósofo nos anos 70 e o senhor no meio disso tudo, já que a ideia de estudar intelectual alemão nasceu inexplicavelmente naquele entrevero. Imagino que como último recurso, embora provisório.

PA - Nem eu: estava pensando nalguns lembretes do tipo elevação continuada da composição orgânica do capital, redundância do trabalho vivo, estreitamento da base social, etc., mas desisti.

ICC - No que andou muito bem.

MEC - Mas e aí? O Roberto Schwarz também entrou nessa de nicht, como é que é mesmo? Enfim, não participar, ou andou participando adoidado? Se precisou cair fora, não foi porque andou se comprometendo com algum engajamento de baixo nível? Que eu saiba, crítica da mercadoria cultural fetichizada pode deixar o Giannotti possesso (uau!), mas não dá cadeia...

ICC - Maria Elisa: faça o favor de não imitar stalinista, nem de brincadeira.

PA - Não, o Roberto nunca entrou nessa, se consigo me expressar com a mesma precisão sociológica da Maria Elisa. Mesmo "desorganizado", acho que em nenhum momento deixou de se considerar diretamente concernido pela luta política. E é claro que também sabe muito bem que marxismo sem luta de classes não chega à segunda dentição. Nem por isso passou por cima da palavra de ordem adorniana. Mas ao levá-la em conta, vem encrenca. Admito que driblou-a o quanto pôde, nem sei se chegou a pensar muito no assunto (quem vinha atrás, com eu, não notava nada). Mas agora está pensando, como já disse. E, também como já disse, salvou-lhe a lavoura o outro Roberto, o alemão Kurz, apartando, com forte apoio na realidade, movimento operário e crítica ao fetichismo enquanto ponto sensível máximo da alienação, que a falência objetiva do primeiro redobrou, coisa que o Adorno vinha dizendo fazia tempo.

MEC - Pois então dê uma amostra do que o Roberto está pensando agora, depois que o Kurz sancionou a independência (é relativa, Iná?) entre revolução e fetichismo.

PA - Não sei de melhor exemplo do argumento novo - além das já sublinhadas ressalvas que balizam seu balanço do Seminário Marx - do que um artigo também recente, junho de 94, uma espécie de história do engajamento, de Nabuco a Fernando Henrique. Uma curiosidade: o então candidato entendeu muito bem o recado, tanto é assim que no discurso de posse se referiu ao "mandato da raça negra" desenfurnado no artigo pelo Roberto (não consta que em campanha andasse com O Abolicionismo debaixo do braço), avisando que o compromisso de Nabuco, a procuração tácita passada pelos despossuídos aos intelectuais, estava de pé, que não consentiria que se reproduzisse o escândalo da dessolidarização social em massa que se seguiu à Abolição sem integração do escravo, dando assim a entender no entanto, talvez mais do que desejasse ou pu- 
desse falar, a saber, que havia sido eleito pela mesmíssima coalizão conservadora de sempre, especializada neste tipo de secessão, como mostrou em 64 e voltou a demonstrar em 89, quando contratou os serviços (muito caros) de um aventureiro: ao menor gargalo à vista e a correspondente pressão popular, desafoga o primeiro abortando a segunda logo que o sócio internacional maior lhe oferece uma segunda chance, devolvendo o povo miúdo ao deus dará que a colônia e o trabalho compulsório nos legaram. Essa a lição de Nabuco, que não poderia ter sido relembrada mais a propósito. O nosso amigo Roberto Schwarz estava portanto revendo nosso passado ideológico à luz de um caso terminal de engajamento, coroamento apoteótico do empenho do Partido Intelectual Brasileiro (daria para imaginar a alternativa "socialista", à luz desta sua exata imagem invertida?), enfim um caso de engajamento intelectual máximo. Como se trata também, nesta exata medida do empenho total construtivo a que sempre aspirou a classe culta brasileira, de uma correspondente capitulação intelectual até a extinção de qualquer vestígio de vida mental, se é verdade que, de um modo ou de outro, há pelo menos dois séculos, a dita vida do espírito não subsiste senão em relação antagônica, por mais indireta e remota que seja com o curso mercantilizado do mundo - é só lembrar que na terra natal do capitalismo industrial, na Inglaterra das primeiras décadas do século XIX, cultura, intelectual e literatura, tanto faz se com maior ou menor acerto de juízo acerca do grande contencioso da época, só alcançaram sua primeira definição social por oposição ao mercado e à infinidade de suas manifestações correlatas -, em suma, ao se consumarem, nossas luzes se apagaram, com uma exceção, no momento inverificável, só daqui a quatro (ou oito?) anos, pois há quem suspeite ser o Presi- dente o único intelectual sobrevivente no atual establishment bem pensante, o único a compensar com algum movimento de prospecção intelectual, tateando aqui e ali, contemporizando ideologicamente enquanto as coisas não se definem, a completa ausência de liberdade no plano operacional, como é do feitio inflexível do círculo vicioso das estabilizações monetárias na periferia, de epicentro exógeno, para usar um eufemismo. Mas onde estávamos mesmo?

ICC - No engajamento (aarrgh!) em fim de linha.

MEC - Pode-se saber a que se deve essa rosnada?

ICC - Existencialismo.

CR - Como eu precisei sair um pouco...

MEC - Você se lembrou da minha encomenda?

CR - Não me lembro nem do que vinha antes. Por isso quero saber o que essa conversa de agora tem a ver com os embananados filósofos uspianos dos anos 70, de onde surgiu o livro de falsa germanística que não posso mais deixar de editar, pois até já deve ter saído, pelo tempo em que vocês estão nesse tricô.

MEC - Tudo a ver, minha cara (não precisa agradecer, Paulo). Pois não é que estamos verificando que o professor Giannotti acredita ser o seu dever de filósofo e cidadão estabelecer coordenadas filosóficas que ajudem o amigo presidente a governar? Então? No conflito das faculdades (nada a ver com divisão, gente!), faculdade de filosofia 
$\mathrm{x}$ faculdade de letras, ponto para nós: não me consta que a crítica literária brasileira, pelo menos na pessoa do Roberto Schwarz, tenha cogitado de iniciativa semelhante. Aliás não deixa de ter a sua graça essa curiosa inversão de papéis: pois não era a filosofia profissional que definhava à margem da vida nacional, enquanto o pessoal que mexia com literatura estava mais ou menos condenado a seguir o empenho construtivo da literatura brasileira?

ICC - Ponto para nós? Devagar com o andor! Não sei não, estou mais para um empate. Observe o seu próprio chiqueirinho, as teorias literárias de vanguarda no vasto mundo globalizado (nos dois sentidos) de língua inglesa.

MEC - Espera aí! Devagar com o andor, digo eu! Eu estava falando da nossa crítica literária, da nossa filosofia universitária, da nossa política e da rede de empenhos intelectuais, como mostrou o professor aqui, tecida à volta do nosso Presidente da República, inclusive por força do próprio passado dele e que tem a ver com os desdobramentos políticos de um capítulo muito original da nossa história intelectual - enfim, um rolo local, encalhado nas contradições locais.

\section{CR - Puxa! O ABC da miséria brasileira.}

ICC - Podicrê. Mas acontece que na última eleição ficou nítida a mudança de foco da luta de classes, arena sem dúvida nacional, porém com centro de gravidade internacional, muitíssimo mais patente que na eleição anterior, mesmo que nossas elites dominantes (e "esquerdas" caudatárias atrás) creditem ao famigerado Collor o mérito da "mudança de agenda" (aargh!), como costumam dizer os cientistas políticos na atual terminologia anglo-burocrática deles, sempre que a modernização conservadora de turno exige um correspondente ajuste no jargão. Pois bem, Dona Maria Elisa (e você, Paulo, dá licença de rasgar o verbo), a penúltima eleição presidencial ainda transcorreu no âmbito exclusivamente local de uma conspiração antipopulista de última hora. Deu no que deu: da parte do aventureiro em questão, uma inestimável contribuição para acelerar o processo de crapulização de nossas classes proprietárias e rentistas. Esse processo, como você sabe, vem de longe, ou melhor, pode-se dizer que elas nasceram degeneradas, se pensarmos que até meados do século passado o jovem Estado Nacional era um aparelho clandestino composto por foras-da-lei, já que o tráfico de escravos havia sido capitulado como crime de pirataria internacional (de fato, num país nascido desse berço, por que filósofo?). De modo que a "mudança de agenda" (aarrgh!), as reformas voltadas para a modernidade encarnada pelas potências ditas avançadas (abertura comercial, privatizações, enfim, esse cardápio diário), deu-se sob a égide do crime organizado, o que não surpreende: sendo o capitalismo por definição extralegal, como costumava dizer a Rosa Luxemburg, compreende-se que uma tal mudança de agenda (chega de argh!) e formação de quadrilha andem juntas (como se pode perceber pelas notícias já confirmadas sobre o México, a Argentina, o Peru, a Rússia, a Espanha, etc., etc.). De resto, o moço desavisado só foi apeado do poder (sem multa, é claro) porque o pedágio que cobrava já estava tomando proporções macroeconômicas, embora se deva dizer em abono do delinquente em questão que o nível atual de financeirização da riqueza torna aquele tipo de aplicação não-contábil quase uma fatalidade. Não estou, evidentemente, querendo com isso insinuar coisa alguma 
a respeito do sucessor dele na gestão da nova agenda, por enquanto. Aliás, nem é esse o meu ponto (estou me lixando), até porque não sou udenista, embora não possa deixar de notar que o Banco Central já torrou doze bi de grana pública no "nosso" sistema financeiro. Mas deixa isso pra lá. O que está me interessando lembrar à distinta colega é que só com a entronização do FHC ficou claro de uma vez por todas que este governo, e os próximos que o atual plano de estabilização ainda conseguir eleger, tem o seu eixo girando no establishment internacional, e por isso a esquerda está no chão e no chão vai ficar enquanto não se der conta, não me importo de repetir, de que a mais-valia em torno da qual lutam classes locais extrapolou as fronteiras nacionais - leva quem tem sócios mais fortes "lá fora", o que inclusive pode ser aqui dentro mesmo. E a nossa esquerda está tão por baixo, tão agarrada (com uma boa dose de razão, sem dúvida) aos antagonismos sociais herdados da fase estatal-desenvolvimentista anterior (com a qual rigorosamente nunca teve nada de substantivo a ver, como de vez em quando lembra o Luís Fernando Veríssimo, aquilo foi coisa da direita mesmo, que montou a contra gosto o tal aparato substitutivo, em benefício próprio, é claro, e agora o desmonta pelas mesmas razões, quando secou a fonte externa, ou melhor, quando mudou o perfil de suas exigências e concessões), que deixou passar sem o menor comentário um artigo, a meu ver um arraso em matéria de esclarecimentos, do José Luiz Fiori, se não me engano publicado na Folha do mês de lançamento do Real, com o título "Os moedeiros falsos", ou coisa parecida, e deixou o barco correr. Deixou mesmo, pois, se encarasse aquele novo enfoque da campanha em curso, perceberia ali a demonstração de que suas chances eram mínimas. Entre outras razões porque, ao contrário do que pensava e de- nunciava, e por isso mesmo sem o menor efeito junto à população que passara a dispor de um papel sobrevalorizado, o Plano Real não era uma jogada monetária armada para eleger o candidato da coalizão conservadora, a candidatura oficial fora por assim dizer construída, não por ela mesma (poderia ser qualquer outro personagem, desde que já fosse de saída um insider), mas para viabilizar uma coalizão de poder capaz de dar sustentação permanente a um programa de estabilização e ajuste estrutural internacionalmente hegemônico.

MEC - Mas onde é que você está querendo chegar, se é que alguém aqui ainda sabe por onde andamos a esta altura?

ICC - À Novíssima Dependência, para falar novamente como o José Luiz. À nova associação subordinada internacional, só que desta vez com desmanche da parte estatal do tripé famoso. Ora, está claro então que o poder executivo atual se desloca no âmbito do capitalismo globalizado, cuja estratégia hegemônica o gerou e lhe dá sustentação. O nosso amigo Roberto acrescentaria por sua vez que esta nova incidência internacional, de um jeito ou de outro, para mal e para bem, acabará desprovincianizando o debate ideológico, sem impedir, é claro, que o novo cosmopolitismo daí decorrente seja tão abstrato e acanhado quanto o antigo debate doméstico. E, se isto é fato, devemos aumentar o ângulo a partir do qual observar as novas filiações intelectuais do seu entourage letrado (ou semi). Por isso a lembrança das teorias literárias anglo-americanas e sua hegemonia global.

MEC - Ainda continuo na mesma. 
ICC - Não há de ser por muito tempo, salvo por implicância ou coisa do gênero. Vou tentar inverter o raciocínio para ver se fica mais claro. Estou simplesmente sugerindo, é claro que de maneira muito rápida, que o tal de "nosso Presidente" (meu não, porque não votei nele) e a "nossa" teoria crítica literária devem ser encarados ambos de um ponto de vista internacional e que, vistas as coisas por esse prisma, a cultura literária teórica pode ser objetivamente tão apologética quanto o fogo (lógico, evidentemente) de encontro do professor Giannotti para evitar que se puxe o tapete da normalidade capitalista, toda ela acatamento à assimetria da nova ordem global, debaixo dos pés do amigo Presidente, enredado, como vimos, não nas malhas imaginárias da social-democracia, mas nas da Novíssima Dependência, que comporta, é claro, a sua correspondente dose de miragem. Por exemplo: o conto de carochinha de que não somos mais um país subdesenvolvido (em algum momento, por acaso, passamos a dispor de moeda conversível e geração endógena de tecnologia e ninguém me avisou?), de que estamos portanto na iminência (reeleição ajudando) de um salto que nos colocaria no Primeiro Mundo (com reposição do atraso, é óbvio: essa a contribuição do presidente-sociólogo em relação à mesma promessa do playboy que o precedeu na rota de la Modernidad).

Ora, me parece evidente o parentesco estrutural desta constelação que alguns analistas americanos situacionistas chegam a chamar de New Colonialism (como lembrou muito bem, para o meu gosto, é claro, o professor José Luiz Fiori) com a fraseologia dominante em nosso campinho literário, fraseologia de língua inglesa que você conhece melhor que eu (que não tenho a mesma paciência, nem obrigação), se é que já não está definitivamente enfarada, o grande coquetel ideológico da "Theory”, algaravia que vai costurando, à medida que aparecem no mercado editorial, Desconstrução, Teoria Foucaultiana do Discurso, Lacanismo, Novo-Historicismo, Pragmatismo e Retórica, Cultural Studies, etc., etc. Estou interessada em uma das últimas composições em mosaico multiculti desse lixão ideológico internacional, embora de matriz franco-americana, a saber, o discurso (crítico? conta outra! teórico? então tá!) da condição pós-colonial. Veja se não estamos em casa. Todo mundo briga muito, tem energia combativa pra dar e vender, e pra quê? Para entregar a rapadura. Do lado dos Executivos estabilizadores nas várias periferias, tanto as adjacentes e anexadas (como o México ao Nafta), quanto as mais remotas e quase abandonadas por falta de quem as explore: um salto de tigre (a batalha das reformas, etc.) para... se ajustar aos "mercados"! Enfim, ligeiro probleminha lógico nessa promessa de autonomia pela heteronomia. E do lado da Desconstrução Pós-colonial, então? O mesmo ímpeto demolidor (das fixações míticas herdadas do período de lutas sociais anterior, bem entendido) correndo pela pista sem barreiras da mais entusiástica conformidade com o atual estado de coisas, que em boa hora o Kurz chamou de "colapso da modernização". Tem muita gente boa dando o troco à ideologia pós-colonial - penso no Aijaz Ahmad ou no Neil Larsen, que conhece bem o Brasil, mas prefiro ficar com a prata da casa. Não só porque também diz tudo e muito mais (pro meu gosto) que os supracitados e outros que não o foram, como também porque formula diretamente o ponto de vista que nos interessa, a homologia entre a desintegração social-nacional homologada pelo ajuste estrutural sob a égide do novo Oligopólio Mundial (não mais do que meia dúzia de executivos centrais, bancos e corporações transnacionais, na qual se concentra hoje a massa absolu- 
ta do poder econômico, político, tecnológico e militar) e a mesma desintegração redescrita pela Internacional Desconstrucionista, em especial na sua seção pós-colonial. Estou evidentemente me referindo ao Roberto Schwarz, em especial a um artigo recente, acho que de 94, publicado na Folha com o título "Fim de Século" e cujo mote se resume ao seguinte problema: o que fazer com a referência nacional (no caso, dos estudos literários), criticá-la (entenda-se: crítica imanente de uma referência-processo e não identidade cultural ou coisa que o valha) ou pura e simplesmente descartá-la, exatamente como estão fazendo os desconstrucionistas pós-coloniais (recorram ou não a este último epíteto) e... os governos periféricos engajados nos programas hegemônicos de estabilização e ajuste, cuja ideologia legitimadora mais diáfana e abrangente vem a ser justamente o culturalismo esvaziado de qualquer substância material dos primeiros. É só reparar nas falas presidenciais (do nosso, agora) para ver como está derivando para um subproduto do velho caráter nacional como instância identificadora de uma sociedade cujo espaço econômico foi pro espaço da globalização. Coisa que aliás o Roberto foi também dos primeiros a notar, junto com a outra observação sobre a Desconstrução (como se vê, estou me limitando a juntar os pedaços): que as especializações da leitura pós-estruturalista (a desestabilização de identidades, teleologias, etc.), anunciadas como liberação, são na verdade uma descrição, involuntariamente empírica e sem o menor conhecimento de causa, do atual processo de fragmentação destrutiva por motivo de modernização capitalista abortada.

Isto posto, que aliás não é quase nada, e aos trancos e relâmpagos, não resisto à tentação de uma comparação impertinente entre o "nosso" Presidente e o ideólogo-mor do fardo pós-colonial, o Edward Saïd, fardo que evidentemente não recai sobre os ombros do indigitado ideólogo, mas sobre o lombo das populações expropriadas das sociedades que Kurz chamou de “pós-catastróficas”, populações desgarradas na condição de ex-proletários virtuais, sujeitos modernos e desmonetizados (índios reduzidos ou mouros, tanto faz) que não têm mais para onde voltar depois da falência das industrializações retardatárias, salvo exatamente a fuga para a frente na forma do afluxo emigratório para as cidades globais do império, e em quais condições sinistras de "proteção" social da força de trabalho podemos facilmente imaginar.

\section{MEC - Você continua brincando conosco?}

ICC - Com vocês, não. É só pensar um pouco nas famosas viagens presidenciais. Todo mundo estrila por nada, vício udenista talvez, falta de assunto na imprensa, enquanto a esquerda (???) reclama que faria melhor, cavando um pouco mais a sua cova.

CR - Iná, peço-lhe que seja breve. Temo pela reputação do meu editado, que infelizmente está com cara de quem está apreciando muito essa conversa, como direi, de andar térreo. Pelo que ouço (e editor tem bom ouvido), o professor aqui já tem fama de ter largado a filosofia faz tempo e, do jeito que as coisas estão indo agora, vai ser difícil provar que não estou vendendo mero jornalismo com cobertura filosófica. (O quê?! O Paulo está me dizendo que o Hegel não desaprovaria a definição, embora preferisse inverter as camadas, caroço e casca, e que, por ele, a Iná poderia continuar filosofando sobre a passarela internacional do Presidente.) 
ICC - Só aceito o "filosofando" com o devido destaque à observação hegeliana: vocês sabem que eu rezo pelas Teses sobre Feuerbach. Mas é pouca coisa. E tão óbvia que tenho até vergonha. Por que viaja tanto o nosso primeiro mandatário? Por razões de política interna, é evidente. Assim, inibe qualquer veleidade sucessória que não a dele por ele mesmo. Semana sim, semana não, mostra na televisão que é insubstituível no jogo com os homens lá fora, que está lá fora o freio da inflação interna. Enfim, que não governa quem não dispõe do mesmo raio de ação multinacional de sua diplomacia estritamente pessoal. Numa palavra, que a política nacional é externa, que a casa cai se algum chefão multinacional torcer o nariz para o primeiro caipira (ou caiçara, dá na mesma) que mandarmos no lugar do atual titular do circuito Elisabeth Arden. Tudo isso em linha, inútil lembrar, mas uma marteladinha nunca é demais, com a identificação, feita pelo sociólogo às vésperas do golpe de 64, do dinamismo específico do nosso "subcapitalismo", isto é, que em nome da liberdade de movimento do capital nossa finada burguesia nacional faz qualquer negócio, ora livre-cambista, ora sob o guarda-chuva protecionista de seus prepostos estatais, com o centro hegemônico internacional (em suma: ele inventou a roda do Programa de Transição, com a diferença que aderiu ao objeto). Esse é um ponto da nossa metafísica social: é preciso que o povão associe o frango a um real e meio o quilo e a prova diária da inflação domada ao que vê nas telas da TV - o Presidente de bem com os gringos de cara simpática. Assim, de salto em salto, de viagem em viagem, de Sivam em lei de Patentes e outros mimos (o interbancário subsidiado, por exemplo), um dia tomaremos assento no Conselho de Segurança da ONU, quem sabe a Secretaria Geral da OMC (se não houver parabólica pelo caminho).
Ora, não é esta a mesmíssima política de alargamento ecumênico do cânon diligentemente incorporada pelo Edward Saïd (podia ser um outro pós-colonial qualquer, a Gaiata Spivak, o Homi Ki Bhabha, etc.) à sua bem sucedida carreira no campus mundial sediado na capital do Império - e vice-versa? Resta a assimetria escamoteada, porém traída pela dinâmica peculiar da Novíssima Dependência e a correspondente hierarquização dos espaços nacionais e subnacionais. Novamente e pela última vez: o que condena os chefes de Estado periférico a uma vida de caixeiro-viajante. (E mais: são cosmopolitas - melhor ainda se já eram antes - por falta do que fazer em casa, além de gerenciar câmbio e juros, de olho no correspondente monitoramento internacional). Sendo escassas as decisões de investimento e ilimitados os territórios disponíveis, é preciso vender credibilidade nas políticas de ajuste. (Aviso aos navegantes: não se afobem! Depois de Salinas e Gonzales, o Brasil terá sustentação suficiente para encarnar durante alguns anos o próximo show case dos acertos da linha hegemônica.) Repito: nosso candidato a futuro novo darling dos caciques mundiais, na sua posição de primeiro violino da periferia (mas precisa combinar com chineses, russos e indianos), não reproduz em tudo e por tudo, enquanto autodesignado representante de colarinho branco dos desintegrados coloniais que ficaram para trás - na galera -, a coreografia de reintegração pela harmonia das diferenças multiculti do atual darling acadêmico, o Said? Se o tiro sair pela culatra, resta sempre a vantagem negativa do olhar excêntrico do exilado colonial na metrópole. Só que, ao invés de esquiar em Aspen, interpretando o papel do professor que experimentou no âmago do poder a relatividade de centros e periferias... 
MEC - Ué! O professor não vai entrar com o estribilho "faço minhas as palavras que acabamos de ouvir, assino embaixo, não saberia formular melhor”, etc., etc.?

PA - No hace falta, você saiu na minha frente. Me satisfaço com um breve complemento. O que vale para a ideologia literária (franco-americana, no caso), a fantasia de levantar voo por sobre os escombros metafísicos da experiência local, abstratamente anulada, e planar nas alturas primeiro-mundistas do cânon expurgado de qualquer resquício de contradições que ainda poderíamos chamar de "nacionais", acompanhada da correspondente fantasia política da modernização como salto à frente destinado a tirar a diferença que nos separa dos países capitalistas "normais" (e já vou lembrando, não só por direito aos créditos, mas porque tal personagem se encontra no miolo de toda esta conversa sobre filosofia e vida nacional, que foi o Roberto quem primeiro observou nos primeiros anos da Nova República o fenômeno inédito em nossa vida cultural, o sentimento de que a elucidação da experiência nacional era uma tarefa anódina ou retrógrada diante da ilusão imperialista de um mundo universalista que nunca existiu nem existirá enquanto a lei do valor der as cartas), vale para o mundo da filosofia (ou aquilo que pela força inercial da tradição terminológica ainda chamamos tal, pois sabemos do passamento do gênero em meados do século passado), mundo globalizado e dividido atualmente em três grandes capitanias hereditárias, e digo globalizado não só porque contribui para a fraseologia mercadológica da "globalização" (no caso, teórico-cultural, no sentido já especificado de "theory" - mingau para o que outrora atendia pelo nome de Teoria, e "cultural" para consumo do respectivo "bem”, cuja incorporação tem o condão de emancipar o consumidor), mas porque convergem e evoluem em conjunto (debate-se...) na região central do Império, os campi americanos, a saber: a Ideologia Francesa, a Teoria da Ação Comunicativa, de origem alemã, e o neopragmatismo americano, que se dá muito bem com as duas primeiras variantes filosóficas, todas as três unificadas sob o programa comum da "virada linguística" que transformou a filosofia de monológica (centrada no sujeito reflexivo, condenado por padecer de surtos paranoicos intermitentes) em dialógica, imantada pela procura (agônica ou não, depende do gosto do freguês, se ascético ou laxista) do "entendimento", compreensão, etc., etc.

Como as duas últimas são afirmativas, a fachada apologética delas chega a ser simpática pela singeleza do conto de fadas a que se resumem: patologias sanáveis à parte (é claro que encontraremos regras internacionalmente acordadas para disciplinar a nuvem especulativa que dá volta ao planeta), as premissas modernas estão dadas de uma vez por todas (para os alemães é resultado de um processo histórico de aprendizado irreversível, para os americanos, o fruto de uma bela contingência a ser protegida por meio de outras adesões a um caso de sucesso). Podemos (e devemos) chamá-las (as tais premissas modernas) de normalidade capitalista e estamos conversados. Não estou caluniando: a normalidade institucional do mundo que o capital gerou tornou-se o ponto nevrálgico (aquilo de que se fala em última instância e noutros termos mais técnicos e específicos) na exata medida em que não há mais crises sistêmicas (como na antiga ordem concorrencial) mas crises ético-culturais de legitimação: à filosofia transformada pela "virada linguística" (por sua vez, esta virada, exigência metodológica da redundância do trabalho vivo e seu correlato na esfera dos atores sociais) cabe 
então a nobre tarefa de investigar as condições (hoje bem menos vinculantes, modestas, enfim) daquela justificação, se uma prática social entre outras ou uma atividade de horizonte normativo mais largo do que o seu raio de incidência original (os americanos preferem a primeira hipótese, os alemães brigam muito pela segunda, mas todos concordam com o objeto mesmo a ser sacramentado, sem o quê não valeria a pena o esforço de emendá-lo). Filosofia de alto bordo, então, é isso: maneiras de legitimar, de fornecer "razões" ou procurar a "regra", ininteligíveis sem a confiança prévia no patamar evolutivo alcançado pela sociedade capitalista enfim totalmente esclarecida quanto ao seu mecanismo basicamente funcional. Com uma diferença: os alemães (a Nova Teoria Crítica como Visão Moral do Mundo) andam um pouco perplexos porque, na pessoa de Habermas, o sistema em novas bases ficou pronto no momento mesmo em que o período de pacificação social do capitalismo organizado chegava ao fim, a "organização" perdida se exprime no cavalo de batalha da "universalidade", esgrime contra o neopragmatismo americano, muito à vontade no campo vencedor que os dispensa dessa última velharia metafísica, "fundar" o que já vai muito bem, obrigado. Resta a Ideologia Francesa, cujo traço idiossincrático é a apologia indireta. Ao atravessar o Atlântico, dividiu-se em duas, uma previsivelmente gauchista como na matriz, predominantemente literária e que acabamos de ver funcionando na transfiguração celebrativa da desintegração do Terceiro Mundo em triunfo ontológico contra enteléquias imperiais, e a outra, mais divertida porque expõe em público seu fundo de afinidade congênita com o establishment, foi embalada e distribuída na forma de transgressão para uso estritamente privado enquanto elemento na modelagem ético-cultural da existência publicamente empenhada, no entanto, na edificação das instituições da ordem liberal-produtiva. Se assim é...

CR- Paulo, nós estamos perdidos no meio do mato. Se em vez de sacar uma bússola você vai abrir um outro dossiê, nem com sinal de fumaça. Acho que originalmente fim da picada deveria refletir um cipoal assim. Mas fique à vontade, a esta altura não vai fazer a menor diferença.

MEC - Pois eu estou achando a maior clareira nesse matagal (não precisa agradecer, professor, é verdade).

PA - Não vou abrir dossiê nenhum, mas deveria. E por uma razão muito simples: quem começa do jeito que eu comecei a desenrolar o novelo do mal estar na cultura filosófica em nosso país, cedo ou tarde terá que se pronunciar a respeito desse rolo filosófico internacionalizado, não por fumaças cosmopolitas (pois seria voltar à estaca zero: a ilusão de estar diretamente engatado no debate filosófico, ou outro, mundial, por força idiossincrática do talento que Deus nunca recusou aos brasileiros, é a mais arraigada das nossas ilusões provincianas), mas por ser este o estado terminal de um ponto de vista instruído (no sentido jurídico do termo) pelo processo que explica os sucessivos desencontros entre filosofia e vida nacional. O "se assim é” de há pouco também poderia continuar assim: reconsideremos a evolução do Giannotti (não por implicância ou prazer de alugar meu ex-professor, mas é que ele resume na sua figura verdadeiramente exemplar todo o drama da consciência filosófica profissional no Brasil dos últimos 40 anos) deste ângulo terminal da confluência apologética dos três estilos filosóficos “transformados”. Se assim é, o 
nosso número um filosófico, ao procurar a melhor lógica filosófica que iniba a crítica ao capitalismo, facilitando na sua imaginação a vida teórica do amigo presidente, está fazendo direitinho a sua lição de casa (daí os tropeços, os rotineiros certinhos não têm nada a temer, jamais a realidade em pessoa lhes pedirá contas). Ele soube levar com muito engenho seus antigos teoremas da reflexão-trabalho para as águas da variante wittgensteiniana da Ação Comunicativa, por isso precisa desancar com tanta veemência o Habermas (que fez exatamente a mesma coisa), e prova por quê, ao temperar a compreensão-entendimento que todos buscamos (não precisa protestar, Iná, está no subtexto) com uma dose de finitude agônica à francesa.

MEC - Podemos voltar, então. Já não me lembro mais se ao engajamento em fim de linha ou engajamento como fim da picada. Mas pela ordem: primeiro, o interesse muito justo da Christine em saber o que aquela história do engajamento intelectual brasileiro segundo o Roberto Schwarz tinha a ver com o "por que filósofo" nos anos 70, etc., etc.; depois a duvidazinha da Iná, aquele negócio de juntar numa mesma pessoa marxismo industrializante e negatividade do nicht-não-sei-o-quê. Aliás, pro meu gosto pelo menos, o Maurício Segall, naquele memorável debate na Maria Antonia do começo do ano (1995) já começou a responder: pra mim, dizia ele com a veemência cabível, essa história de marxismo sem prática, sem luta de classes, essa história de que teoria já é praxis, se não a verdadeira praxis, pode ser o que vocês quiserem, menos marxismo; arrumem outro nome então, sem essa de ocidental ou que for. Então é isso aí: intuição original do Brasil, concordo, quem sou eu pra discutir, mas sociologia modernizante, claro que mais sofisticada, mas sociologia universitária, sim, e como tal não vejo bem por que o drama do participar ou não. Não era assim mesmo em Frankfurt depois da guerra: o carinha podia perfeitamente fazer pesquisa no horário comercial e depois se embrenhar na selva oscura da música negativa, sem uísque no meio, é claro (ou não?), cuja função acadêmica é sabidamente sublinhar a demarcação entre ciência positiva e devaneio especulativo?

\section{ICC - Deixa comigo!}

PA - Sirva-se, porém a seu tempo. É que primeiro preciso responder à Christine. Mas antes, não gostaria de passar adiante sem tirar o chapéu em reverência ao golpe de vista da Dona Maria Elisa. Não sei se o Popper pensou no uísque para demarcar a linha divisória entre ciência (refutável) e filosofia (que não se consegue desmentir). Me lembrei dele porque você empregou o termo demarcação. E olhe que ele imaginava estar corrigindo a rigidez positivista do Círculo de Viena, Carnap em primeiro lugar, a meu ver ao preço de uma regressão, como se ele, em nome de uma fluidez maior nas fronteiras, recuasse aos tempos anteriores à Crítica (kantiana) em que ciência e filosofia (cujos problemas deveriam necessariamente ter raízes extra-filosóficas, científicas, no caso dos maiores) podiam se cruzar na vala comum do conhecimento (ao contrário de seus confrades do referido círculo neopositivista, acreditava piamente na existência de verdadeiros problemas filosóficos). Mas isso não o impedia de acompanhar os ditos confrades quando por exemplo justapunha à pesquisa dos problemas teórico-científicos testáveis a metafísica negra do primeiro Heidegger e demais filósofos da Vida da República de Weimar. Aqui o seu uísque entra no meio, sancionando a mediação inexistente no mundo das socie- 
dades industriais avançadas (para deixar descansar um pouco as palavras "moderno" e "capitalista") entre teoria e prática, saber especializado e céu das ideias; ele é o combustível do reino animal do espírito. Vindo depois do expediente, o uísque anuncia que os problemas decidíveis ficaram para trás, no escritório, e que estamos entrando no domínio das grandes escolhas sem valor de verdade, cujo reino cessa na abertura do pregão na manhã seguinte. Um bom scotch consagra assim uma compartimentação de mão dupla: o que distingue um positivista de um existencialista é que o primeiro não bebe em serviço, ao passo que o segundo só em serviço, por isso é que se pode dizer de muitos deles, os verdadeiros, que trabalham em tempo integral - é claro que os moralistas da última Escola de Frankfurt diriam que da superação da separação entre filosofia e experiência vivida não se segue nenhum efeito emancipador.

MEC - Você não está querendo insinuar que o Roberto não toma uísque por uma questão de método, né? A propósito: se não me engano, acho que numa entrevista, falando a certa altura dos usos e costumes do grupo da revista Clima, a Dona Gilda de Mello e Souza lembrou que o Rubem Braga não levava muito a sério o grupo, porque eles não gostavam de uísque. Você também não está sugerindo, não é mesmo, que o vinho é o elixir da dialética, que ele quebra o gelo da frieza burguesa, restabelece um sistema de vasos comunicantes entre sujeito e objeto, abrindo caminho para a totalidade?

ICC - A tradição brasileira é muito generosa nesse capítulo: não obriga a escolher. Na falta de qualquer caráter teórico (para não falar em firmeza política), vamos levan- do o barco como o velho comandante, em regime de comunhão de bens. Tenho a impressão de que a rotina pode ser tocada com uísque, enquanto a quimera se acompanha com vinho. Ou vice-versa?

PA - Isto aqui está ficando muito sibilino.

MEC - Quem falando!

PA - É melhor responder logo à Christine. Quem foi mesmo que proclamou: tudo a ver, entre os embananados filósofos uspianos dos anos 70 (por onde andava a conversa) e o ponto final do engajamento descrito pelo Roberto Schwarz?

MEC - Fui eu mesma e mantenho. O Professor pensa que a gente não lê jornal... O que dizia o Roberto? Que nunca fomos tão engajados, só que o nosso empenho intelectual acabou virando de ponta-cabeça a tal procuração tácita do Nabuco. Na ausência da antiga assimetria, privação social absoluta de um lado, preparo político-ideológico do outro - desequilíbrio convergente entre cabeça e coração que a ponte do engajamento transformava na mola propulsora de uma aliança de classes. Embora continuasse o mesmo, o capitalismo mudou, tornando o engajamento intelectual quase um anacronismo. Vamos conferir a periodização. Em plano mundial, duas datas. A primeira, mais ou menos pelo fim dos anos 60/início dos 70, com o fim da Guerra do Vietnam e a arrancada épica que ele prometia, encerrado o ciclo terceiro-mundista das guerras de libertação nacional (por onde o Sartre, pai da ideia, havia começado no âmbito internacional, Argélia, Cuba, etc.), desapareceu um dos polos negativos que induzem o engajamento. 
Como o outro também se desmanchou logo depois de 68, pelo menos durante algum tempo pareceu favas contadas que a integração política e cultural da classe trabalhadora se completara, paradoxalmente por motivo de vitória relativa (mal desconfiava do revertério que vinha pela frente), pois diante de sindicatos poderosos e bem assessorados por especialistas, o apoio dos intelectuais fazia figura de Napoleão de hospício. A segunda data diz respeito à atual virada globalizante do capitalismo e o novo exército mundial de excluídos que ela está formando, baralhando as oposições de classe tradicionais, revistas à luz da divisão maior entre a minoria dos integrados e o restante desorganizado e heterogeneamente despossuído da população. Aqui, quem sabe, uma chance para a velha inspiração democrática do engajamento intelectual. (Estou resumindo bem, professor? Quase literal? É que eu reli e anotei tudo outro dia mesmo, quando ficou claro que a nossa conversa ia passar por aqui. Gente preparada é conosco mesmo: lição de casa tinindo!) No Brasil, em ponto menor, é claro, uma curva análoga, acrescida das cores nacionais, a fibra cívica das camadas cultivadas que vibrou retesada na Independência (depois das reformas joaninas), na Abolição (sobretudo), com a modernização deflagrada a partir de 30, e finalmente no encaminhamento pacífico porém fervoroso da Abertura. (Melhor que a encomenda, hein, Professor? Como eu li uma cópia clandestina do seu depoimento para Teoria e Debate, sei que agora vem pela frente uma outra tremenda guinada radical do contra ao a favor). O que se passou então no Brasil? Pelo menos, duas viradas importantes. Também nos anos 70, os grandes sindicatos do $\mathrm{ABC}$ saíram fortalecidos das greves do final da década, enfraquecendo substancialmente o fundamento da ascendência intelectual do período anterior, a ponto de engajamento parecer redundância; resultado, subentendido, mas já ouvi conversas do Roberto a respeito: já que não podiam dar as cartas, barrados pela autoridade política e moral das lideranças sindicais, a maioria dos mandarins intelectuais se desinteressou do futuro partido socialista dos trabalhadores e preferiu de longe continuar influindo no partido ônibus chamado agora PMDB, como já vinha fazendo antes desde 74 em torno do Ulysses Guimarães e sua roda de políticos oposicionistas. Aqui a segunda virada.

ICC - Dez, Maria! Se melhorar, estraga.

PA - Posso abrir um parêntese?

MEC - Parêntese serpente?

PA - Na verdade, um paralelo com a conjuntura francesa, entre o ano milagroso (sobretudo pelo milagre que não ocorreu) de 68 e o de 81, vitória de Mitterrand nas eleições presidenciais, seguida da freagem do programa socialista em 83, e a co-habitação com os neoconservadores em 86, prenunciando o desastre final do segundo septanato. A certa altura do artigo que estamos repassando, a propósito da morte matada do marxismo (é bom não esquecer: um cachorro muito chutado pode estar vivo), o Roberto reconhece que, de fato, com a reversão parcial naqueles anos de 70 da semiexclusão social do operariado, o impulso ativista do marxismo sofria uma baixa considerável, mas nem por isso (aqui o novo tópico introduzido pelo Kurz no repertório de nosso amigo, na verdade não assim tão novo, à vista das análises adornianas, a novidade está na mudança de configuração global do capitalismo), nem por 
isso, então, ficara comprometida, ao menos teoricamente, a crítica ao fetichismo da mercadoria (mas tirar em novas bases sociais as consequências práticas desse balanço é que são elas), muito pelo contrário. Prova disso é nossa muito conhecida campanha local para desqualificar a crítica ao capitalismo e à cultura que o potencia. Chegado a este ponto, nosso amigo recorda que, reabsorvidos os efeitos do maremoto de 68, a lógica da mercadoria conheceu uma expansão brutal, tanto na esfera popular como na cultural - para maiores detalhes e sua correspondente ordenação, remete ao excelente ensaio do Fredric Jameson, "Periodizando os anos 60". Aqui a comparação que gostaria (se pudesse) de desenvolver, de olho no similar brasileiro dos anos 70 e um pouco mais adiante (afinal não é esta a hora dos filósofos uspianos embananados, à procura do que fazer, encerrado o período clássico de formação?). Então, na França: pois foi neste clima espiritual novo de subordinação avassaladora à forma-mercadoria que se consolidou o gauchismo pós-estruturalista. Observemos, para começar, duas reações características ao refluxo que se seguiu à grande queima de 68: durante algum tempo ainda prevaleceu a convicção gauchista de que as energias emancipatórias continuavam fervendo sob a opressão das instituições mal das pernas pela contestação recente, "hipótese repressiva" que Foucault se encarregaria de revogar já na segunda metade da década, alegando que o Poder com maiúscula, embora capilar, era positivamente produtivo, mas na primeira metade do período Gilles Deleuze e depois Lyotard (segunda ou terceira maneira, já não lembro mais) já haviam posto de pé um dispositivo "teórico" destinado a recolher no rescaldo do pós-68 evidências que, devidamente estilizadas, permitiriam transfigurar a hegemonia renovada das forças do capital numa espécie de triunfo afirmativo, de sorte que, de vitória em vitória, o combate continuava num front imaginário habilmente administrado pelas escolas em presença, numa arena fortemente iluminada pela mídia.

Deleuze saiu na frente com as Máquinas Desejantes, às quais Lyotard acrescentaria os dispositivos pulsionais correspondentes de sua "economia libidinal". Ato contínuo, a parceria se dedicou à elaboração conjunta de um diagnóstico metapsicológico do capitalismo contemporâneo, taxado de "energúmeno". (Como se vê, continuamos na velha trilha da apologia indireta, identificada por Lukács na segunda época da Ideologia Alemã, a que vem depois da derrocada de 48). Assim como o Sujeito Automático é um energúmeno, o marxismo (aqui não há dúvida: é o marxismo do movimento socialista mesmo) é um viveiro de ressentimentos de intelectuais na velha acepção nietzscheana do termo; a defunta Dialética é uma paixão triste; a Crítica também é outra monomania da vontade atrofiada, coisa negativa, mefistofélica (houve quem se lembrasse do Diabo no Dr. Fausto de Thomas Mann), ao passo que só o esquizofrênico traz em si a semente vanguardista da verdadeira Revolução. Numa palavra, os acordos de Grenelle, e tudo o mais que daí se seguiu, não eram a demonstração cabal da escandalosa servidão voluntária (outra fórmula mágica ressuscitada na época) das classes subalternas? Afinal, não era mesmo verdade que o proletariado alemão "desejara" Hitler? Nestes termos, o que era então a "economia libidinal” do Dr. Lyotard? Um expediente, vanguardista, é claro, porém àquela altura um realejo de segunda mão, que consistia em apresentar como transgressão o mergulho sem culpa no mundo fantasmagórico da mercadoria, ela mesma portadora de intensidades libidinais explosivas: pois não era isto o que 
profetizara a ruptura estética dadaísta e depois surrealista? Pois então, estamos conversados. Pois era esse o passe de mágica, a mudança de sinal, da recolonização fetichista das energias emancipatórias desencadeadas na década de 60 e que culminam no 68 mundial.

Como isso incidiu na imaginação intelectual brasileira são outros quinhentos, sobre os quais a Maria Elisa estava na bica de falar, e eu também daqui a pouquinho. Mas antes (e logo depois duas palavras sobre a Desconstrução, que também começou a deslanchar nos anos 70), não acho demais indicar os próximos passos da Ideologia Francesa na pessoa do Lyotard, pois o cruzamento seguinte é dos mais importantes para quem está de olho na evolução do similar nacional. Pois então, mais para o fim dos anos 70 o Dr. Lyotard atravessa o Atlântico e redescobre na América a Ideologia Francesa em seu verdadeiro habitat, que reexporta a seguir para o Continente com o nome de Condição Pós-Moderna. Finalmente (já viramos a década), a deriva pulsional que ainda procurava o calafrio da liberação no paroxismo da sujeição integral, cede a vez ao dissenso "pragmático" multiplicado pelos jogos de linguagem incomensuráveis, pois o nosso ex-gauchista trouxera na bagagem o Wittgenstein II, promovido a teórico número um do "différand". Cá estamos de novo (avançando outra vez na cronologia): não vêm ao caso eventuais contrassensos, o fato é que estava registrada em cartório a virada linguístico-pragmática de um ramo da Ideologia Francesa. Aqui entra a outra família da transformação filosófica que acompanha o falso movimento de estabilização do capitalismo desde que assentou a poeira da década turbulenta de 60 (tudo aqui são projeções, e respectivas reações a esmo, retroalimentadas pelos trinta anos gloriosos da Pax Americana).
Então: posição consolidada no próximo passo do nosso ideólogo, a saber, em bom francês, chercher querelle com o Habermas. O pobre tipo deixara inadvertidamente de incluir Lyotard no elenco de pós-estruturalistas franceses em guerra aberta com o assim chamado, pelo nosso personagem, Projeto Moderno. Não direi (nuançando um pouco o que disse mais atrás) que se trata de uma falsa querela, longe disso. Apesar dos pesares, Habermas ainda continuava batendo na tecla (moral) da emancipação (moralização dos temas públicos, como ele próprio diz, contra a amoralização dos conflitos públicos promovida pelos tecnocratas de sempre, desde que o Estado entrou no mercado com seu programa substitutivo: mas faz tempo, hein?), sobre a qual nós já conversamos, emancipação na era do capitalismo sistêmico (mas como envelheceu!) se resumiria então ao empenho de retaguarda na "descolonização do mundo-de-vida”, ao passo que a agonística que o Dr. Lyotard reencontrou submersa no antiessencialismo do segundo Wittgenstein (as semelhanças de família curiosamente acirram uma espécie de guerra civil permanente entre paradigmas efêmeros).

ICC - Um gerente de marketing não iria tão longe. Chamaria simplesmente de concorrência acirrada entre produtos similares. O mercado é pra quem pode.

PA - Registrada a observação, posso continuar? Obrigado. Eu dizia que a agonística do Dr. Lyotard pretendia ter lançado uma pá de cal naquela última ilusão oitocentista, uma Grande Narrativa tão mítica e violenta quanto a quimera metafísica de um jogo de todos os jogos, etc. Tudo isso não obstante, com a ressalva do jargão, Habermas não diria que não, como já falamos um pouco a respeito, 
admitindo, mas agora com conhecimento de causa (e nós também, por nossa parte, ou não?), que o capitalismo estabilizado (estávamos nos primeiros anos da década de 80 !) também o obrigara a descartar, entre tantas outras coisas, uma certa ideia substantiva de Razão, mais precisamente (como já estamos fartos de saber e conversar a respeito. Fartas? Tudo bem: acato a objeção feminista, até porque ela me exclui), precisamente a ideia de Razão no sentido da Filosofia da História, a qual viria a ser, por seu turno, dá pra adivinhar, o gênero supremo da tal Grande Narrativa da Emancipação - e assim por diante, se fosse o caso de prosseguir nessa curiosa espiral de confrontos e renúncias comuns. Seja como for, não deixa de ter sua graça, vistas as coisas na sua gravitação de conjunto, lembrar que por sua vez o próprio Habermas estava igualmente convalescendo da descoberta tardia dos atos linguísticos performativos, enfim, como arquisabido, descoberta recente (para a tradição alemã, as primeiras coisas do Apel são de meados dos 60, se não me engano, e olhem que estamos falando de um ex-assistente de Adorno!) de toda a pragmática da função comunicativa da linguagem no âmbito da interação simbólica, patati, patatá.

Bem, já que estamos aqui, novamente nas proximidades do nosso filósofo número um, mas no seu new look de agora (depois comparemos com o "que fazer" dos anos 70), mais uma volta no nosso parafuso. É bem verdade que a guinada pragmática do último representante da Teoria Crítica alemã custou bem mais de uma década para amadurecer, além de a preceder de outro tanto a correspondente mudança francesa de "paradigma". Tamanha lentidão, como é fácil imaginar a réplica parisiense, se deve menos a alguma pretensa maturação em profundidade do que à provinciana inércia alemã na travessia de qualquer limiar moderno. Este passe de armas imaginário não é assim tão frívolo como poderia parecer à primeira vista. A lepidez tão brasileira dos ideólogos franceses, sempre dispostos a mudar de cenário e passar do pró ao contra, é a espuma de um lento desmoronamento subterrâneo, colapso das grandes continuidades culturais burguesas, daí o curioso parentesco crepuscular com a nossa inconsistência congênita. Não custa insistir (já que bifurcamos de vez, mas logo retomo o caminho da roça) que nesse cotejo imaginário de precedências também se espelha o teor mundial específico dessas defasagens que, aliás, repito pela enésima vez, nos concernem diretamente, sobretudo agora quando enfim com o lançamento do Wittgenstein do Giannotti chegou a hora de periodizar a involução (logo voltamos ao engajamento, dos anos 70 ao seu fim de linha) do marxismo filosófico brasileiro, também ele é claro, no rumo da dissolução.

Mais um pouquinho de Giannotti então. Já expliquei porque o realce. Se tudo correr bem (na Presidência da República?), a crise de paradigmas vivida por Giannotti terá sem dúvida alcance mundial. (Mais adiante falaremos um pouco de sua mais recente, de dezembro de 95, Lógica da Emancipação, um argumento realmente alucinante, que todo mundo já leu, imagino). Voltando ao nosso Fla x Flu: quem saiu na frente de quem? A rigor, ninguém. Guardadas todas as proporções, a Ideologia Francesa e a Nova Teoria Crítica Alemã têm a bem dizer a mesma idade. A companhia pode até ser lisonjeira, mas nem por isso, é muito fácil prever, o Giannotti deixará de estrilar ao se ver (e não se reconhecer) comprimido entre as duas fatias complementares da fraseologia contemporânea (deixemos por enquanto os neopragmáticos americanos de fora), além do mais, é óbvio, ladeado por autores que não 
entenderam nada (alguém duvida?) da revolução wittgensteiniana. É preciso convir de fato que à primeira vista não há nada mais incompatível com o ânimo construtivo do nosso filósofo do que a curtição francesa da diferença pela diferença, mais a fieira de descentramentos que a costuma acompanhar.

Retomo então o que já disse lá atrás um tanto rápido demais: por isso mesmo não deixa de ter a sua graça, uma graça suplementar, observar Giannotti lançando contra Habermas os mesmos estereótipos que a Ideologia Francesa reserva aos retardatários da única revolução que conta aos olhos dela, a da Linguagem e seus efeitos subversivos de realidade. Assim, tanto empenho na busca de um "claro e diáfano entendimento" (botem aspas), por exemplo, só se explicaria da parte de um nostálgico da totalidade, da sociedade transparente, do "retorno glorioso da razão clássica” (se não me engano, aspas de novo). Etc., etc. Nesta toada, Giannotti também acabou encampando o assim chamado "sublime" (para não espichar ainda mais, deixo o "mercado" enquanto ilusão transcendental para mais adiante, se descarrilarmos de novo em nosso roteiro). Pois "sublime" é um outro clichê reposto em circulação pelo Dr. Lyotard para evocar o pathos vanguardista de um outro estereótipo, o não menos famoso inapresentável, só que com o sinal curiosamente trocado, aplicando (o nosso Giannotti, agora) aquela cifra do intelectual refratário ao seu exato par antitético, o esprit de sérieux do progressista siderado pela beleza que emana dos interesses harmonizados. Mas essa inesperada afinidade não quer dizer que Giannotti não tenha razões próprias para também por seu turno procurar briga com Jürgen Habermas, coisa que vem fazendo desde uma breve passagem do "Ardil do Trabalho”, um ensaio, depois capítulo, de 1973, onde re- cusa em bloco (e continua recusando até hoje, seja dito em seu favor, não importa o que faça depois com isso) a distinção categorial habermasiana entre trabalho e interação, sem imaginar que ela viria a ser eclipsada pela virada linguístico-pragmática que ambos viriam a executar no futuro (próximo para o alemão, mais remoto para o brasileiro). É claro que com uma diferença de ênfase básica no que concerne o pomo da discórdia em pauta: enquanto Habermas dificilmente engole o caráter culturalista (e trivialmente antropológico) do pragmatismo linguístico do segundo Wittgenstein, a ponto de não se acanhar de introduzir corretivos, como a expectativa universalizante de entendimento do agente que segue uma regra, Giannotti se deixa levar pela multiplicidade paroquial dos infinitos jogos de linguagem possíveis. (Embora não o seja, isso por enquanto é detalhe). Ponto.

Imagino que vocês devem estar querendo me fuzilar por esta digressão num parêntese que ainda não fechei. Mas, cá entre nós: não deixa de ser divertido acompanhar a evolução desses laços de família arrevesados, reconhecer no nosso filósofo número um (e ninguém está pensando em lhe sonegar as honras do posto) o decalque invertido do passado gauchista de um confrade parisiense (cuja existência aliás sempre ignorou solenemente, não sem razão, quando olhamos para trás na sua obra) no momento mesmo em que sua guinada linguístico-pragmática, acompanhando, como era do seu dever de filósofo do ser social, a mudança de paradigma do capital (cuja lógica agora é cultural), vinha encaixar-se com sóbria naturalidade, a título de suplemento ontológico fiscalizador (sobretudo, niente critica), no lugar que finalmente lhe fora reservado pela mutação dos mapas cognitivos na coalizão conservadora de turno, encarregada do passo moderni- 
zante exigido pela hora histórica da grande virada à direita do planeta, sempre na esperança, é claro, de tirarmos uma casquinha progressista da manobra em curso às nossas costas, etc., etc.

MEC - Que nó! Dá um tempo, vai, Paulo! Não que eu não esteja acompanhando o papel mais recente do Giannotti. Mas arrume um pouco melhor esse negócio da Ideologia Francesa. Você sabe do meu interesse pessoal nisso...

PA - Posso me explicar de outro modo (pensando por comparação na Ideologia Francesa dos 70 e, de outro lado, no ajuste filosófico local uma década depois), dizendo simplesmente que a apologia indireta se deslocou, variando apenas o foco: primeiro, grande estridência oposicionista porém reconciliando-se com o novo curso do mundo. Assim, o professor Lyotard precisava dizer, para início de conversa, que o capital era o Grande Energúmeno para em seguida celebrar sem remorso o casamento do desejo com a mercadoria, estilizando triunfalmente a proletarização das forças sociais antes liberadas que deram aos anos 60 sua energia (para me exprimir nos termos certeiros do Jameson já citado).

Segunda posição, agora local: a título de ilusão metafísica ou erro lógico não podermos mais nos livrar do modo de produção de mercadorias como um fim em si mesmo. Poderemos quando muito interpretá-lo filosoficamente...

ICC - Ai que saudade do Marx das Teses sobre Fenerbach!

PA - Eu dizia que, segundo essa posição local, podemos quando muito interpretá-lo filosoficamente, hermenêu- tica desenganada (a filosofia deixa tudo como está, salvo recurso terrorista ao mito do esclarecimento total das relações sociais) à qual o nosso Giannotti, com inegável tino estratégico, confia o ingrediente oposicionista da pequena negatividade, o sentimento sem remissão da finitude: como não tirar o chapéu três vezes diante deste grande jogo de linguagem, o do situacionismo agônico? Mas isto já nos anos 80 e bem avançados, pois ainda estamos na década de 70, quando ainda não sabíamos que nos preparávamos para um tremendo ajuste intelectual. Achei que vinha ao caso me referir aos ideólogos franceses por isso: enquanto a conjuntura nos países centrais, de reenquadramento generalizado, só (ou já) consentia aos gauchistas rescaldados a mascarada libertária do fetichismo pulsional, por aqui o pêndulo, cuja corda estava distendida ao máximo pela resistência à ditadura e a miragem do day after, o pêndulo da cultura de esquerda, se é que é preciso deixar claro, ainda oscilava de preferência para o lado reforma-desenvolvimento-revolução (?), portanto, nos termos da conversa de agora, para o lado engajamento, que o esquerdismo parisiense estava mandando para o brejo sob pretexto de inocular má consciência na bela positividade do desejo. (Mas logo viria o troco: em 81, com a vitória do Mitterrand, os intelectuais franceses também começariam a ficar menos tagarelas, para grande prazer da nova direita; algo semelhante ocorreria no Brasil e basicamente na mesma época, mas disso a Maria Elisa estará falando daqui a pouco).

CR - E a Desconstrução, sobre a qual você prometera duas palavras? Acho que ela faz parte do nó que a Maria Elisa quer ver desatado. 
PA - Estava mesmo pensando nisso. É claro que dentro do quadro bem específico pressuposto pelo Roberto (e como lembrado por ele mesmo, apresentado com detalhe no ensaio do Jameson, já mencionado), o da expansão violenta da lógica da mercadoria com a ressaca de 68 , povo miúdo e highbrow desta vez em conjunto e diretamente concernidos por essa nova atmosfera de arrastão ideológico (relembro que o nosso amigo Kurz a rigor data deste momento a percepção da independência relativa dos temas da revolução e do fetichismo da mercadoria na obra de Marx, independência relativa, já que o eclipse do primeiro não acarreta necessariamente o colapso do segundo enquanto esquema crítico, sem falar é óbvio no supracitado recrudescimento do objeto mercadoria-fetichizada por motivo do dito eclipse). Pois é dentro deste quadro indutor do tipo de apologia indireta que acabamos de identificar em funcionamento na Ideologia Francesa do apogeu meia oito dos anos 70 (brilho ofuscante de estrela extinta) que se pode rever de outro ângulo o $\mathrm{ABC}$ desconstrucionista: aqui também se sublima e se inverte o sinal de um panorama desastroso. Pois o sucesso da Desconstrução (vocês se lembram da caracterização do Roberto, a Desconstrução como uma descrição vulgarmente empírica da atualidade e seu cortejo de equívocos e desenganos?) tem muito a ver com um outro naufrágio de época, o desmanche ou a desilusão que deixou o terceiro-mundismo sem objeto. Não podemos esquecer que, para bem e para mal, a margem esquerda parisiense foi a capital do terceiro-mundismo, que ele nasceu e morreu lá. Ou melhor, morreu para ressuscitar na forma de uma fraseologia altamente codificada, embora primária. Na ausência de objeto real, ou por outra, quando a periferia revela a sua cara prosaica (o que deixava um Pasolini verdadeiramente desconsolado), o tropismo que afinal também arrastou seus heróis negativos para a esfera de influência do consumo sem porteira, não houve um ideólogo parisiense que não inventasse um terceiro mundo para si mesmo. Primeiro, os últimos produtos da fantasia política (da Revolução dos Cravos ao Irã dos aiatolás, no qual se atolou o pobre Foucault, com perdão do trocadilho), depois o terceiro-mundo interno dos novos movimentos sociais, agora as banlieues amotinadas. É claro que a lista termina com o atual fastígio da crítica pós-colonial, nossa conhecida. Assim, pode-se dizer que uma larga fatia de Ideologia Francesa é terceiro-mundismo imaginário (e toda sorte de tropelias demagógicas que inspira). Não estou exagerando, não. É só lembrar do cadáver intelectual, passando por cima do qual subiu na vida o Estruturalismo, depois o Pós-Estruturalismo, etc.: Sartre, não é verdade? Nome próprio de uma filosofia da consciência (horror!) onde o lugar do Resistente foi aos poucos ocupado pelo Colonizado. Só que a Argélia era real, e Cuba também, como mais adiante o Vietnam e a Palestina. Quando o objeto se desintegrou, ninguém mais se interessou por Imperialismo e luta de classes, mas pela transfiguração do mesmo na forma de Discurso. É só traduzir, ou melhor, subentender, Logocentrismo e seus correlatos por Ocidente (ou cânon), e estamos conversados, a saber, somos todos de vanguarda.

ICC - Nós, vírgula: os companheiros sobrantes de colarinho branco e beca, eternos bolsistas no coração da metrópole, podendo estar, o dito coração, tanto no centro quanto na periferia.

MEC - Tá legal. Agora quero voltar ao meu fichamento. Breve história do engajamento intelectual brasileiro 
segundo Roberto Schwarz. Segunda virada: a mudança nos termos da procuração social passada desde a origem da nacionalidade ao pensamento brasileiro quebra-lhe o ânimo crítico e lhe restringe a abrangência. Sintoma: resposta intelectual decepcionante à feição decepcionante da Abertura. Minha modesta contribuição: a prova de que a embananada filosofia uspiana, mordida desde o berço pelo mesmo ânimo cívico ao qual procurava mas ainda não sabia dar forma, finalmente encontrou-a e por isso mesmo quebrou a cara junto com os demais companheiros de Partido Intelectual. Tal prova existe e está documentada na página ao lado do mesmo número do jornal que publicou o primoroso artigo do nosso mestre na periferia, o Professor Roberto Schwarz.

PA - Invejável capacidade de síntese e concisão. Permite um preâmbulo?

MEC - Só se forem mesmo duas palavrinhas.

PA - É que revendo os últimos vinte anos de nossa história intelectual por esse prisma do engajamento, ficam mais nítidas certas distribuições de papéis ideológicos. Em tempo: não sei a quem atribuir a exumação do termo "engajamento", há muito desmoralizado e caído em desuso. Aos jornalistas que conceberam a matéria em função da ironia involuntária de uma campanha presidencial polarizada entre dois candidatos que justamente ocupavam as posições que outrora armaram a convergência não antagônica da referida procuração tácita passada pelos nossos damnés de la terre aos nossos radicais de ocasião (e segundo Antonio Candido, pai da fórmula, Nabuco foi o maior de todos), de um lado um antigo assistente da ca- deira de Sociologia I, do outro, o coração proletário de que ele em princípio deveria ser a cabeça (o que o jovem Marx teria pensado de tamanha reviravolta do casamento que arranjara entre teoria e prática, ainda quentinho, saindo do forno feuerbachiano?), ou aos autores especialmente convidados a opinar sobre o estado atual das relações entre intelectuais e política? O Roberto sem dúvida deve ter se lembrado ato contínuo do ensaio de Adorno do mesmo nome (Engagement) criticando a ideia sartriana de arte engajada, no próprio e no teatro político de Brecht (a Iná está fazendo cara feia...). É bem possível que tenha procurado um equivalente, para o efeito político que se poderia esperar de uma vida intelectual independente, da carga crítica imanente à autonomia da forma artisticamente configurada: uma coisa porém é certa, pelo menos, que o elogio materialista da torre de marfim feita na ocasião tem muito a ver com o nichtmitmachen adorniano que há horas a Iná está querendo discutir. Dito isso, o meu lembrete era só para avisar que não podemos esquecer que a palavra de ordem sartriana do "engajamento" do escritor (e não tinha nada a ver com militância política num partido revolucionário) tinha a mesma data conceitual da correspondente transformação da filosofia (epistemológica) profissional, com todas as ressalvas que já fizemos, se é fato que não podemos perder de vista que em princípio o nosso interesse maior está oficialmente no caráter e destino da filosofia uspiana nos anos 70, e de lá prá cá. Ponto.

Parágrafo. Agora o preâmbulo ao “tudo a ver!” da Dona Maria Elisa (entre o que fazer com filosofia em meados da década de 70 e o "nunca fomos tão engajados" às vésperas da eleição de um presidente-intelectual, primorosamente planejada por technopols treinadíssimos na Costa Leste e adjacências). É que a lembrança da Ideologia Francesa me 
ocorreu, como estava começando a dizer e não me parece demais retomar agora, por realçar a seguinte divisão do trabalho nos círculos intelectuais da esquerda confrontada com a ditadura e a perspectiva de seu fim, que por certo viria, mas em que termos ninguém sabia. É que o mecanismo peculiar da apologia indireta bem maquiada da fraseologia radical parisiense comoveu apenas, naquela quadra, digamos a ala propriamente estético-cultural, ala periférica de aliados, compagnons de route do Partido Intelectual, cujo núcleo duro era evidentemente político. Todo mundo, é claro, pensava e (quando possível) votava à esquerda, mas se serviam diversamente do article de $\mathrm{Pa}-$ ris, os duros então (sociólogos, economistas, politólogos, etc.), nem pensar. Havia é claro a turma da filosofia política, mas aqui já estou me antecipando, pensando num curiosíssimo entrecruzamento.

Vamos ver se o consigo pôr de pé. Não sei quem foi o primeiro a falar em Democracia. De qualquer modo consta, e na prática foi isso que contou, que teria sido o próprio Fernando Henrique, ali por volta de 74, um pouco antes, um pouco depois, não sei bem, dando início, ele e seus colaboradores mais próximos, a uma longa demonstração pública de que o famoso aprofundamento do capitalismo periférico não exigia automaticamente o controle político incontrastável do Estado Autoritário. Isso como desdobramento tático (para começar) da Teoria da Dependência, obra coletiva e multifacética, como se sabe e não vem ao caso agora (depois sim, e muito). Ora, mais ou menos pela mesma época, a Marilena Chauí, para ficar com o nome próprio mais em vista, por razões intrínsecas é claro, de uma outra tendência do Partido Intelectual que começou a se cristalizar a partir de então, tomando corpo por exemplo logo depois (só para dar uma ou duas refe- rências) na criação do CEDEC em 1976, para a qual ajudou muito um grupo emigrado do CEBRAP, terminando por desaguar no vasto estuário de que nasceu o PT na virada da década... Aqui o interessante (e se conseguir reencontrar o fio, retomo o ponto, a saber, a resposta da Marilena ao nó uspiano identificado por Giannotti, no meio a referência mais ou menos direta à experiência brasileira: não sei se vocês ainda se recordam, mas esse era o nosso cenário original, contra o qual se deslocava o bisonho uspiano filosofante sem saber direito o que fazer com sua recente descoberta incompletíssima do Brasil, numa das mãos e, na outra, a falta de jeito congênita da mal abraçada profissão de professor de filosofia), o interessante é que a Marilena, pelo menos no princípio, depois o debate pegou fogo, introduziu o tema mais por razões doutrinárias. Enquanto no CEBRAP e adjacências (UNICAMP, por que não?) Democracia era a senha política óbvia de um diagnóstico objetivo - repúdio às tendências excludentes do "modelo", que no entanto era modernizante e portanto dinâmico embora dependente, encerrando de vez o debate sobre imperialismo e estagnação -, no campo dito muito mais tarde popular Democracia era, de um lado, uma espécie de cunha a ser introduzida no grupo rival, pois todo mundo sabia, ou melhor, suspeitava (depois o Bernardo Sorj historiando o CEBRAP e o período confirmaria o ponto sensível) que pela porta da democracia entrariam outros temas tabus que rachariam aquele farol intelectual da resistência, como a questão do capitalismo à luz da crítica socialista, o nacionalismo e as alternativas de uma economia dependente no sistema internacional, etc.; e, por outro lado, o lado por assim dizer encabeçado pela Marilena e sua já àquela altura enorme influência nos meios oposicionistas, Democracia era uma formulação, digamos, um 
tanto especulativa (na acepção filosófica da palavra), colhida nada mais nada menos que no pensamento francês, e aqui tropeçamos (digo sem retórica nenhuma porque estava pensando noutra coisa quando principiei esta digressão) noutro caso do maior interesse para o estudo do sistema brasileiro de enxertos, transplantes e similares. É favor notar que não falei em Ideologia Francesa, todo lo contrario! Pois a fonte em questão, como todo mundo sabe, o Claude Lefort, já pela linguagem tarabiscotée era, se confrontado com a Ideologia Francesa, que detestava, ele e seu então fiel companheiro, mentor ou seja lá o que for, Castoriadis (em dupla ou separados fariam escola no Brasil), o que nós poderíamos chamar de verdadeiro passadista, a começar (seja dito a seu favor) pela herança bem resguardada de Merleau-Ponty, de quem transferiu aos poucos a crítica ao ultra-bolchevismo (tanto lítero-filosófico, quanto propriamente comunista) para o gauchismo dos "modernistas" da Ideologia Francesa (aliás, até onde eu sei, Castoriadis foi o primeiro a empregar a expressão para designar o que mais tarde os amigos franceses do Projeto Moderno chamariam de Pensamento 68). Pois foi então a Democracia redescoberta na contramão do vanguardismo parisiense (que também via Gulag por toda parte, na fila da esquina como em qualquer instituição disciplinária, com perdão do pleonasmo) que aterrissou numa das secções mais combativas e já dissidente do nosso Partido Intelectual, enfim o Partido do Engajamento. Aqui, portanto, pouco importa se mencheviques ou bolcheviques, todos engajados e cada vez mais, lembrando o título do Roberto, na acepção brasileira do termo, autorizada pela tradição a costear de alma leve as manifestações mais inequívocas de civismo. Mas por onde andava então a Ideologia Francesa?
MEC-Afinal, pretextopara estepreâmbulodiversionista...

PA - Obrigado. Se já disse, repito: de preferência nas páginas culturais da imprensa alternativa, nos nanicos da resistência à ditadura. Diga-se de passagem que todos liam, os duros do engajamento à brasileira, after hours, alguns possivelmente bocejando, mas só quando se tratava de algaravia teorizante, pois consumir ao vivo, quem não consumia a produção artística correspondente?

ICC - Vai ver que só o futuro Presidente da República, naquele momento já cogitando de uma suplência no Senado. Como ontem, na melhor tradição da cadeira de Sociologia I, devia achar aquilo tudo perfumaria. No caso, frescura bem vinda porque somava na oposição. Hoje também deve achar graça vendo seu entourage siderado de estesias nas Opéra de la Bastille da vida, possivelmente pensando no Dr. Getúlio jogando pingue-pongue com Dona Darci depois do almoço. Andou certo o espírito escarninho que viu em FHC o último intelectual deles.

PA - Não sei, o decoro exigido pelo cargo não me permite opinar. O que sei, pois é do meu tempo, é que vi muitos dos nossos, digamos marxistas ocidentais mais arejados (pelo desejo? pelos filmes do Jabor?), compensarem as frustrações do Pacote de Abril e outros entulhos autoritários com alguma intensidade Odara ou coisa que o valha. Não estou falando em pó (aliás, nada contra), mas em poeira ideológica mesmo, isto é, lembrando que a apologia indireta personificada pela Ideologia Francesa corria solta nas altas esferas pós-tropicalistas e outras esferas. Apologia indireta ou falsa negatividade ou ainda negatividade afirmativa, sei lá, daquela fetichização às 
avessas daquelas vanguardas retardatárias na cena europeia, gesticulação e mimetismo do extinto impulso surrealista de conquistar para a revolução as forças do êxtase. Mas acho que vou ficando por aqui. Por enquanto era só uma tentativa de ver como funcionavam na década de 70 e um pouquinho depois (se não em 78, certamente a partir de 82, muda tudo, para nós paulistas, a eleição do Montoro governador) dois esquemas correlatos do Roberto (Schwarz): primeiro, o fio condutor de seu balanço do Seminário Marx, o contraponto e finalmente a exclusão mútua entre crítica cultural de verdade (negatividade, e não consumo orientado) e progressismo marxizante ou marxismo progressista, que o diagnóstico do Kurz trouxe para o primeiro plano, industrialização recuperadora $x$ mercadoria fetichizada; segundo, o outro fio que puxa a análise do nosso padrão de engajamento intelectual, em particular seu apodrecimento atual. Aqui o ponto por onde comecei e a Maria Elisa deve retomar e poderia resumir de outro modo (já que a gente conversa, conversa, é para dar enfim com a boa formulação sem jogar fora o que vem antes, diferentemente da escrita que não deve deixar rastro nem alinhavo, se me passam este lance de meta-conversa). Mais ou menos assim: por artes da gravitação de conjunto de metrópole e periferia, como sabemos, também ela desigual e combinada, a mesma lógica da mercadoria em violenta expansão no pós-68 que no centro colonizou a contestação gauchista deslocando-a para o falso front fetichista da cultura, no fundo afirmativa, só que indiretamente (a segunda metade ponta-cabeça da crítica marxista), essa mesma maré de intransparência social avassaladora ao se espraiar pelas margens de modernização retardatária acabou "engajando" (ao contrário do dégagement apologético parisiense) as três famílias do Partido Intelectual na promoção e administração da normalidade capitalista recuperadora (do atraso). Assim, vale para vanguardeiros veteranos, democrático-populares e desenvolvimentistas-com-política-de-Estado, uma fórmula perfeita que o Roberto cunhou há dez anos na intenção do primeiro pelotão: alinham-se com o poder como quem faz a revolução. Foi naquela virada da década dos 70 para os 80 que de fato o capitalismo entre nós começou a empilhar vitórias, e olha que a Abertura finalmente batia à porta.

MEC - Terminou?

PA - Sim e não. Mas fale você primeiro, enquanto eu penso se acrescento ou não um rabicho sobre a Desconstrução no Brasil. Mais exatamente, comparar a linha evolutiva dela, no que diz respeito à relação entre o nacional e o global, como se sabe, incidindo portanto sobre um nó clássico entre nós, com a da esquerda intelectual propriamente política, também surpreendida num momento de ênfase carregada na atualização. Vamos ver se encaixo noutra hora, pois afinal o passo crítico que estamos devendo, nós desajustados, é óbvio, deve pelo menos começar por aí. (E a filosofia nisso tudo, examinada pelo crivo da vida nacional? Acho que está claro, não? O que não é irrelevante já se ajustou. Quem sabe uma chance para ao menos a boa irrelevância, o sexto sentido que fazia um Bento Prado da fase heroica, só de pirraça, apostar todas as suas fichas num arabesco bem perfumado).

MEC - Isso é que é fila de espera. Fico até encabulada, depois de tanto tempo de chá de cadeira, de entrar em campo só pra dizer que ao ler jornal ligo uma página à seguinte. 
Agora, pra dizer o que observei, precisaria, como vinha fazendo, resumir o artigo do Roberto sobre o engajamento intelectual brasileiro, que não deu no seu contrário, mas num rebaixamento tal ao se realizar que passou a pedir exatamente o seu contrário, o tal do nicht-não-sei-o-quê, que ainda está atravessado na garganta ortodoxa (no bom sentido) da Iná. Aliás, Iná, já trocamos umas figurinhas a respeito. Resume pra mim, que depois eu concluo dando um passe de bandeja pro professor, que já anda meio perdidão, com a chance de reatar com o fio da conversa, perdido lá atrás.

ICC - Então, a pedido, aqui vai a segunda parte da moda do engajamento: com Roberto no barco. Muito bem. Já sabemos como e por que mudaram os termos da procuração tácita alla Nabuco. Passemos então aos ingredientes da acomodação ideológica em curso. De um deles, já se falou: Abertura decepcionante, resposta intelectual idem. E para agravar um pouco mais o quadro, o Roberto se dá ao luxo de dizer que os nossos "varões sabedores" ficaram ainda por cima devendo um esquema explicativo à altura do grande conchavo entre os conservadores dos dois lados que negociaram o fim do regime militar. Eu incluiria no rol das respostas intelectuais decepcionantes ao ilusionismo da Abertura a naturalidade (para não dizer coisa mais pesada) com que uma gorda fatia da inteligência oposicionista assumiu cargos executivos a partir de 82 nos governos estaduais, até 84 em nome da luta contra a ditadura, de 85 em diante, em seu próprio nome e do aperfeiçoamento democrático, retomada do crescimento, etc., etc. - só no Estado de São Paulo foram três mandatos consecutivos, o quarto diverge porém em continuidade: francamente, não há vida intelectual que resista a tamanho engajamento.
Estou evidentemente carregando nas tintas (pensando bem, até que não), mas o Roberto, que continuo a glosar, diz o mesmo, até pior, só que com um cuidado infinito, pois foi o partido dele, ou melhor, a fração majoritária, "desenvolvimentista"...

MEC - O Paulo está fazendo sinal de que gostaria de comentar essas aspas.

ICC - Depois. Eu ia dizendo a fração desenvolvimentista com aspas do Partido Intelectual que se encalacrou. Quebrou-se o ânimo crítico da década anterior mais combativa. Nem mesmo a experiência de governo valeu como reconhecimento do terreno inimigo; segredo de ofício aprendido iria servir, isso sim, para continuar "operando". Enfim, do lado de dentro e do lado de fora (tutti amici), o mais constrangedor silêncio intelectual (idem no PT que também se preparava para administrar, acrescento por minha conta), e era difícil distinguir companheirismo de simples torpor mental. Em poucas palavras, logo, logo, interesses criados e consolidados. Como foi lembrado, na França os intelectuais também começaram a se aquietar um ano antes, em 81, quando a maioria social se tornou maioria política com a vitória do Mitterrand. Essa miragem embalou muita gente boa dos dois lados do oceano. Debray no governo, PCF idem nos primeiros tempos, máquinas desejantes desativadas, aparecem os primeiros habermasianos franceses (quem diria!), Foucault se converte à ética (pode? verdade que um souci de soi meio barra), e Saint Lyotard aos jogos de linguagem, enquanto Deleuze fala de cinema (em geral) e a Desconstrução do Frère Jacques vira ideologia americana. Seguindo o roteiro do Roberto, nada me impede de concluir (acho que 
nem ele) que a já identificada expansão do reino da mercadoria fetichizada coincide com um auge social-democrata no Continente (Mitterrand, Felipe Gonzales, etc.). Assim, com muito tato, o nosso autor vincula a esterilidade relativa da produção intelectual no período...

MEC - Por que relativa?

ICC - Concordo com a pergunta, mas não posso abusar demais do direito de expor o Roberto. Então ele vincula a esterilidade da produção intelectual do período à aparência de sociedades estabilizadas e racionais impingida pela Social Democracia mesmo nos melhores espíritos. Bom, por "melhor" aqui eu só consigo entender o Chico de Oliveira, que identificou um "modo de produção social-democrata”, antecâmara do socialismo porque nele já é visível o nascimento do antivalor (o que eu posso fazer? social-democrata tem dessas coisas...) e, no entanto, no tal Partido Intelectual rachado, ninguém mais oposicionista do que o mestre Chico de Oliveira, que não perde ocasião de avisar que a outra ala, que se mira na mesmíssima Social Democracia europeia, está arrebentando com o país. Todo apoio, mas não é esta a briga no momento, e sim o ponto do Roberto, a saber, que nas duas alas "desenvolvimentistas" (para deixar de fora por enquanto os radicais-populares que ajudaram na fundação do PT) ainda há pouco adotavam todos como horizonte teórico a pacificação europeia, de fachada social-democrata ou não. É prova disso a ira despertada nas duas alas pelo livro do Kurz que, ao descartar o raciocínio por modelos, incluindo todas as possíveis combinações intermediárias de Estado e Mercado, deixava incomodamente a descoberto a crença das duas facções, hoje inimigas, na normalidade capitalista a ser tocada concedendo-se mais ou menos espaço à luta de classes, ou conflito distributivo, conforme as preferências terminológicas de cada um dos contendores. Enfim, que há ideólogos, claro que há, mas neoliberalismo não é mera questão de ideologia, como também não é o neodesenvolvimentismo - são interesses políticos muito claros, não importa o nome que eles prefiram.

Mas voltando ao engajamento, que não se esgota na ilusão de que finalmente está sanado o divórcio entre teoria e prática nas sociedades industriais complexas quando se está no governo, no bom governo, segundo eles. Este é apenas o ponto culminante mais visível da farsa objetiva do engajamento, que se alastrou por toda parte. Não era isto o que se queria? Pois nunca estivemos tão socializados. No caso do bom governo, ainda havia o forte álibi histórico de uma tradição ilustrada que remontava à Era Vargas e depois à Era da CEPAL. Mas agora a coisa desandou de vez, sobretudo por falta de anteparo ideológico, está cada vez mais difícil de convencer o público em geral de que os nossos conhecimentos especializados estão a serviço de algum aperfeiçoamento modernizante qualquer. Continuo na pista do Roberto, que chamou as coisas pelo nome ao fazer um pequeno rol de roupa (suja, pro meu nariz) no empenho de cada um: administração pública, partido, universidade, instituto de pesquisa, sindicato, aspiração de profissionais liberais, relações públicas, redação de jornal, etc. (só não aceito que se inclua nesta enumeração comprometedora a danação do ensino de primeiro e segundo graus, cujo pó muita gente ainda vai comer quando o ensino dito superior desabar de vez). Em suma, o progressismo de cada um demonstrou na prática não que a teoria é outra coisa, mas que não tínhamos uma noção exata do teor mesmo daquilo que imaginávamos ser vida intelectual no Brasil. 
Não deu outra, a conclusão do Roberto é fulminante: como nenhuma energia emancipadora se cristalizou na famigerada passagem da teoria à prática, o compromisso social dos intelectuais acabou tomando a feição desmoralizadora (sem deixar de ser mobilizadora, e como!) de quem simplesmente comparece e vai "tocando o serviço", na fórmula mortal do nosso autor, que arremata com a seguinte pá de cal, como todo mundo deve estar lembrado...

PA - Eu acabei decorando, de tanto me perguntar se eu também não venho "tocando o serviço" faz tempo.

ICC - Eu acho mesmo que ninguém escapa, nem nós. Mas a pá de cal: a atual combatividade do intelectual engajado tem muito mais de lobby de si próprio do que de advogado gratuito dos "de baixo".

MEC - Iná, que horror! Você simplesmente não en-ten-deu na-da!

ICC - O Roberto, você quer dizer?

MEC - Tanto faz. Você está, ou vocês estão, com os mapas cognitivos totalmente desatualizados. Segundo um artigo do Ricardo Musse do Jornal de Resenhas do comecinho de janeiro (96), sobre um livro tipo Anais de Seminário, vários cientistas sociais brasileiros demonstram com rigor analítico e ânimo político isento, que na década de 80 nós já éramos felizes e não sabíamos, que o aposto "década perdida" que lhe pespegaram é fruto de uma tremenda injustiça com uma década rica em experimentos políticos, econômicos e intelectuais (perdão, acadêmicos). O Ricardo me disse que o livro, não por acaso, tem uma capa ver- de muito decorativa, do tipo how green was my valley. Agora vêm vocês dizendo que o engajamento até o pescoço acabou com a vida do espírito. Qual é? Vocês não leem jornal? Pois não é que ainda outro dia ninguém menos que o Michel Camdessus, o todo poderoso diretor do famigerado FMI, numa reflexão rigorosa e sem concessões acerca do papel central do mercado na dinâmica do progresso, acrescentou: o rigor na gestão econômica dos países emergentes não pode abrir mão em hipótese alguma do elemento profético que atrai os homens e os atinge pelo processo unificador do universo. E mais: devemos dissecar a patologia da globalização com o olhar lúcido de um Pascal e ter a coragem agônica de apostar que da lógica dos preços virá a reconciliação. Não precisa agradecer. Minha cara, a que se deve esta ponderação senão a uma espiritualidade profunda e vivida? Eu tenho um amigo que é dono de uma corretora de valores. Neste último Natal ele me disse que segunda-feira não sai de casa sem ler uma coluna semanal não sei em que jornal, não me lembro direito se intitulada sistema financeiro e transcendência, ou coisa parecida. E por acaso eu mesma li noutro jornal um banqueiro reclamando, com fervor, proteção para as esferas da vida que verdadeiramente contam e precisam ser preservadas e protegidas do capitalismo, como a família, o balé e a natureza. Não é a própria vida do espírito encarando de frente o negativo? Não é isto engajar-se, encontrar-se a si mesmo no mais absoluto dilaceramento?

Gente, nós estamos vivendo uma verdadeira revolução cultural, como me explicou o meu amigo, uma mudança radical de conceitos a respeito de tudo o que o país aprendeu nos últimos 30 anos. Segundo ele, que é do ramo, verdades como é bom para o Brasil ter saldo comercial, se endividar pouco no exterior, exibir situação financeira 
folgada nas trocas com outros países, todas elas passaram a ser mentiras herdadas de um passado ainda próximo. Não é isso dialética, a dialética substantiva do verdadeiro e do falso? Uma revolução cultural, sim, garante o meu amigo, e o nosso Lin Piao deve estar na área externa do Banco Central - palavras de insider. Vamos então ao livrinho verde dele, recomenda o Ricardo Musse. De fato, por que essa suspeita infundada, descabida, injusta, recaindo sobre os que ousaram transpor o hiato entre saber e poder? Não ascenderam ao governo os atores da coalizão antiautoritária, cujo principal ativo político era e continua sendo (e como!) sua qualificação intelectual combinada à capacidade de converter em estratégias econômicas os novos critérios de legitimação política? Portanto, minha gente, reconversão dos mapas cognitivos já! (Iná, ou estou muito enganada, ou já ouvi você lançar aqui mesmo esta palavra-de-ordem, num momento de automatismo eufórico...)

Repito: vocês estão defasados. Atrasados de uma reconversão que se realizou precisamente na década de 80 , uma década ganha, portanto. Os nossos intelectuais estavam metabolizando suas experiências. Não só e principalmente no exercício de suas tarefas governamentais, mas em todas aquelas outras arenas, pejorativamente nomeadas pelo Roberto, de cuja soma se formou o bloco da autoridade moderna. Afinal, estamos ou não numa knowledge society? As empresas não incorporam informação e conhecimento como condição para agregar valor? Precisa da Roseli, que é craque em composição orgânica do capital, para explicar tudo de novo? Até eu, que ainda não li O Capital, entendi! Pois sejamos kurzianos até o fim! O que tem demais num, digamos, kurzianismo neoliberal?

Silêncio dos intelectuais? Esterilidade relativa da pro- dução intelectual? Momento intelectual apagado? Parem com isso! Pelo contrário, naquela década verdadeiramente ganha, o que não faltou foi o trabalho do negativo, sem o qual não se aprende (por exemplo, o tipo de saber novo associado à inside information), turbulento, penoso, frustrante mesmo, porém épico como é da natureza das travessias. O Musse, que leu o livrinho verde, assim me resumiu a grande lição da década de 80: nela assistimos a uma verdadeira Bildung (ele sabe alemão, né?) hegeliana, a um processo de aprendizado, e como em toda formação desse porte a experiência que a consciência faz é uma reconversão em que o novo objeto nasce trabalhosamente do antigo. Compreende-se que tenha sido lenta (o Musse diz que nesses casos o conceito é muito paciente) e dificultosa essa travessia de uma cultura oposicionista para uma cultura governista. Ele concluiu com uma observação que eu não sei se entendi, pois é muito técnica, nem se vou saber reproduzir direito: é para reparar bem que essa Aufhebung, porque nega a antiga cultura porém conservando, daí o caráter progressista da modernização em curso, erroneamente, quer dizer, abstratamente, considerada conservadora, pois a crítica oposicionista negada encontra-se idealmente presente na afirmação situacionista, essa Aufhebung, então, é seletiva, ela só transmuda em cultura governista aquela cultura oposicionista predominante apenas nas elites já relevantes antes mesmo de ter acesso ao poder. Como é que diante de tamanha reengenharia dialética vocês vêm me falar de engajamento encalacrado e outros mimos? Francamente!

CR - Estou arrepiada! Quer dizer então que um entusiasta da Constituição de 1988, como o Dr. Fernando, é um agente desestabilizador? Que com ele no barco estariam dadas 
as circunstâncias de rota explosiva rumo à ingovernabilidade? Mas então ele seria uma espécie de cavaleiro andante do populismo econômico!

MEC - Christine, você se lembrou da minha encomenda?

ICC - Eu, por mim, vou ver se ainda arranjo o mapa cognitivo que saiu como encarte no Estadão de fim ano.

MEC - Cuidado com imitações. O Angeli anda dizendo que vai lançar o mapa cognitivo dele...

CR - Não seria mais um caso do que os psicólogos chamam de dissonância cognitiva? No ano retrasado nós editamos um livro a respeito.

ICC - Quando vocês terminarem, me avisem, que estou a fins de pôr um ponto final nesse negócio do engajamento: estamos todos no mesmo barco tocando o serviço.

MEC - Um francês que estivesse à altura da dialética agônica do Ocidente, como o Camdessus, diria que este barco é o da globalização, que nele nous sommes tous embarqués. Se tivéssemos fé, além de uma boa máquina de calcular probabilidades, é claro, Pascal recomendaria a aposta na existência do mercado...

CR - Não seria isso uma alegoria da nossa finitude? E não devemos neste fim de século perscrutá-la, e mesmo amá-la?

ICC - Ai! Chega de mala! Tenham ou não vocês acabado de filosofar, acho melhor continuar de onde a Maria Elisa me interrompeu. Eu estava dizendo que, como era do seu dever desde a Abolição, a inteligência brasileira deu enfim um baita Salto Participante pra ninguém botar defeito. Num certo sentido, um salto mortal, mas que fez um puff bem balofo ao tocar em terra firme. Não invoquei a fórmula benta em vão, já me explico. O que afinal o Roberto apresentou senão a fórmula resumida de uma verdadeira dialética do engajamento? Com perdão da expressão retumbante, foi isso mesmo: ao se realizar plenamente, seguindo seu impulso natural, o dito cujo mostrou ser o contrário do que pensava ser. Não me canso de admirar a sutileza do Mestre: um processo local de reversão no seu contrário, descrito objetivamente nos seus próprios termos, e a crítica, de uma imanência tal que nos implica a todos, sem dó nem piedade. Nos implica na lógica da mercadoria, cega para as boas intenções, como sempre, ao mesmo tempo em que (sem deliberação explícita, imagino, tal o grau de impregnação) contrabandeia um par de teoremas frankfurtianos acerca da ironia objetiva que define os processos de emancipação nas sociedades totalmente administradas (como dizem lá na língua deles), pelas várias hipóstases do valor de troca (é bom que se diga). Continuando a minha impressão, estou convencida de que estamos diante de uma manifestação nacional de um capítulo maior da Dialética da Aufklärung, já na acepção histórica mais evidente do processo de Ilustração: a própria modernidade enquanto Esclarecimento em marcha desintrincou (vocês deixam?) uma da outra as várias esferas culturais específicas de legitimação (já que estamos no barco, deixa eu também tirar uma casquinha dos habermasianos), e por isso mesmo gerou, com a força cumulativa de toda divisão do trabalho, as inúmeras culturas de especialistas que agora é preciso fazer refluir, a fim de 
vivificá-lo, dar-lhe fluidez, etc., sobre um cotidiano racionalizado pela administração e pela economia. Só o pequeno caso brasileiro já mostra no que deu esse compromisso ilustrado dos especialistas, é claro que impulsionado por uma tendência global à formação do novo bloco das capacidades integradas: o engajamento rompeu comportas sociais, trouxe a cultura dita desinteressada para o comércio dos interesses comuns, como lembrado pelo Roberto, e o que se viu? Uma dialética do esclarecimento em tamanho fluminense: a tão esperada diferença democrática que essa descida à terra faria, em absoluto, não ocorreu; ao tão esperado casamento progressista entre teoria e prática não se seguiu nenhum efeito emancipatório. Pelo contrário, aprofundou-se o fosso, por capitalismo mundializado interposto, entre o país organizado dos que sabem alguma coisa em condições de agregar valor ao produto, e o país desorganizado dos sem-coisa nenhuma, tal como nos tempos de Nabuco. Está coberto de razão o nosso amigo Roberto Schwarz: corremos o risco de ver reprisado o desastre da Abolição. Muito bem, teoremas frankfurtianos.

Mas tem mais. Não quero, ou pelo menos ainda não, verificar em que medida estamos reabrindo ou não o dossiê "epilegômenos dialéticos sobre teoria e praxis" (ainda estou por aqui de Stichwooorte, mas na hora certa topo encarar mais uma briguinha). Agora estou mais interessada numa outra dimensão do Salto Participante dos nossos assinalados varões sabedores. Não sei se estou enxergando demais, mas pra mim é muito evidente que a parábola descrita pelo engajamento dos intelectuais foi antecipada por esgotamento análogo das vanguardas artísticas, cujo programa radical de abolição da distância estética entre obra e vida social, no melhor dos casos, reconduziu as melhores obras dessublimadas de volta ao es- paço separado do museu. Também não vou discutir agora a maior ou menor pertinência da tese adorniana acerca do envelhecimento e consequente perda de tensão da arte avançada. Está claro que ela tem a ver (como a Otília me ensinou e explica sempre que solicitada), e nisso acho que estamos todos de acordo, com a convergência de princípio entre revolução social e a utopia estética da arte moderna radical. Se ela ocorreu, foi por pouco tempo e sou de opinião que a história do desencontro posterior é uma história política, de revolução e contrarrevolução em plano mundial. Mas deixa prá lá, não quero atrapalhar. O Adorno tem um roteiro diferente para essa dissociação, e como quero fazer justiça às referências do Roberto (se é que são essas mesmo, sem decalque automático, nem precisa lembrar), não custa segui-lo, até porque com o esquema adorniano acerta plenamente no que diz respeito à pirueta tardia do Salto Participante. Enfim, pra não dizerem que estamos fugindo do assunto: assim como a Filosofia sobrevive porque a Revolução deu prá trás, deu-se a doravante falsa superação vanguardista da arte autônoma com o recesso sem remissão da luta política. Aqui a carga negativa da dimensão estética expurgada de seu antigo caráter afirmativo da era burguesa-liberal. Mais um passo e daria para concluir que o Roberto, a esta altura do campeonato (bem entendido: início da era globalizada, FHC ou qualquer outro estabilizador mundializado que o suceda e, sobretudo, em função do novo quadro, devidamente instruído pelo colapso do engajamento que nos transformou a todos em operadores do Capital), a esta altura o Roberto procura um equivalente político de tal modo imunizado contra essa outra falsa superação da distância entre teoria e prática que certamente só poderá encontrar inspiração no credo adorniano similar quanto à força de iluminação 
da forma artística independente e polemicamente pós-burguesa. Acho que este é o fio de prumo da reabilitação materialista da torre de marfim.

MEC - Finalmente! A sua dúvida sobre o nichtmit-não-sei-das-quantas! Muito esperta!

ICC - Mas não sei se vai dar pra esclarecer a duvidazinha. E cadê o Paulo?

CR-Está bem aíatrás de você, tirando uma linha, pitando.

MEC - Por mim, ele pode ficar mais um pouco de férias. Vai, Iná, continua.

ICC - OK, só queria concluir por onde comecei a digressão, o Salto Participante.

MEC - Você sabe que na escola eu não gostava de Geografia. É em Piracicaba?

ICC - Pior, é Concreto. Quero que um raio me atinja se o Roberto não estava pensando nos Concretos. Não só neles, é claro, mas sobretudo no pioneirismo deles quando tratou da fusão dialética entre participação intelectual e lobby de si mesmo. Autobombo é com aquela turma mesmo, especialista em encarreirar-se através da vitimização em praça pública, em mover cruzada em causa própria. Quem não se lembra da polêmica com o lonesome cowboy passadista Tolentino? Pois não é que o vanguardista passou até abaixo assinado de louvor e apoio à folha de serviços prestados ao fomento das Belas Artes no município e no mundo? Lembram? Pois então. Engajamento é isso, e em fim de linha avant la lettre. Mas vanguarda também não é isso, sair na frente? Como se tratava de uma vanguarda requentada, meio velhusca e desdentada, era uma ponta de lança abstrata, sem parte nem memória, só barulho manifestante, com a "negatividade" da velha guarda europeia dos tempos em que a arte de vanguarda não era exatamente mais um melhoramento da vida moderna. Daí o duplo caráter premonitório. Primeiro, e vejam só que curioso, alinharam com o progresso técnico, com a industrialização, com a quebra simbólica da dependência, exportando poesia que hoje se poderia chamar (e não falta quem chame, a sério) "mundial" (como um carro), etc., repercutindo no plano da racionalização estética o impulso recuperador (para falar como o Kurz, neste caso) do nosso marxismo ocidental (tanto o uspiano quanto o histórico-estrutural, de corte cepalino, para juntar logo de uma vez as duas famílias). Por outro lado, enfim, dada a abstração daquele engajamento inteiramente afirmativo, a participação estreou com força total já como lobby de si próprio. Quando então verificamos que nunca estivemos tão engajados como nos dias de hoje, justiça seja feita, pelo menos nisto os Concretos foram de fato uma guarda avançada, de algumas décadas, aliás.

MEC - Pois então passemos ao Salto Participante da filosofia uspiana. A não ser que a Iná prefira tirar de uma vez aquela dúvida sobre o... (como eu diria?) "não-participar" do pós-marxismo ocidental brasileiro...

ICC - Não há de faltar ocasião. Mas quero registrar, à maneira do mestre Fernando Novais, que I appreciated very much a sacada terminológica da colega, mesmo sem ter certeza de ter entendido tudo. 
MEC - Vou aperfeiçoar o invento. Voltemos então ao fim da filosofia clássica uspiana.

ICC - Para bem ou para mal?

MEC - Vem aí mais um prêmio incentivo?

ICC - Não, só estou tentando adivinhar quem seria o nosso Feuerbach...

MEC - Pronto! Lá vem! Dispenso erudição. Pra mim, fim é fim mesmo: no que deu. E filosofia clássica uspiana, claro! Não é dos maiorais e do seu apogeu que estamos falando?

ICC - Ah, bom. Então retiro a hipótese. Com o Feuerbach houve de fato uma dissolução, um desmanche-consumação. Só que ao entregar os pontos a filosofia clássica alemã passou mesmo desta para melhor, em todos os sentidos. Em boa dialética, com o passamento, o finado é de fato ultrapassado e, se passou bem, não é passado morto.

MEC - Isso é meio abstruso, mas deu para perceber que você teme o pior. Mas então passemos à Dialética do Engajamento pelo prisma da filosofia profissional paulistana. Se não houver elogios, prossigo. Obrigada. O que eu venho querendo dizer faz tempo é super simples. Dá até vergonha. Eu, pelo menos, me diverti bastante quando, terminando de ler no Menas!, o elogio da torre de marfim feito pelo Roberto, pelos motivos nada edificantes que já estamos todos carecas de saber, virei a página do jornal e dei de cara com o artigo do Giannotti: nem que fosse de encomenda, parecia jogo combinado para o Roberto ganhar de goleada. Ora com a mão direita, ora com a mão esquerda, o nosso filósofo número um ia cavando o próprio túmulo, engajado até o pescoço, como um personagem de Beckett. Tudo, é claro, em nome do alto nível, e do compreensível custo proibitivo das instituições em que funcionam os nossos intelectuais.

CR - Mas não seria esta a moeda do tributo devido à finitude?

MEC - Até pode ser. Mas seria injusta se não registrasse que o Giannotti fala em "engajamento mitigado", por certo encarando o engajamento como algo da ordem do estar desde sempre lançado no mundo, e no mundo anônimo e vicioso da instrumentalidade.

CR - Curioso. Eu me lembro muito bem dos meus tios falando da Alemanha de Adenauer, dos tempos da reconstrução, como a certa altura, menos no mundo dos negócios (confusos naquela época de milagre acelerado), mas no domínio bem mais protocolar das instituições públicas, não havia iniciativa, por mais prosaicos que fossem os interesses envolvidos, que não desse a entender que fora tomada para aplainar o atrito da existência em sua ânsia por maior autenticidade. Segundo eles, não havia discurso de inauguração de piscina pública (e, pelo que eles contavam, os empreiteiros deviam ser personagens de Fassbinder) em que não se falasse de Mitsein, Angst (acho que poderia ser Furcht, em se tratando dos futuros usuários), Geworfenheit (como eu era pequena, achava que devia se referir a mergulho, ou a não empurrar os outros dentro d'água).

ICC - Ihh! Voltaram a filosofar de novo! 
MEC - Sinto muito, Iná, mas você, de novo, não está en-ten-den-do na-da. O exemplo da Christine acertou na mosca. Não é professor? Ela não está ilustrando uma irradiação social da filosofia? E não de uma cultura filosófica qualquer, mas da filosofia transformada. Tudo bem que profissional, mas por acaso tem outra? Não foi esse um dos tópicos já vencidos nesta conversa? Então! Filosofia profissional, só que pós-epistemológica. Quer dizer, se eu entendi a lição: uma hermenêutica pós-kantiana da existência, pois só a partir dessa transformação da filosofia é que se pode falar em engajamento também nos seus domínios. Certo, Professor? Ué, cadê o Paulo?

CR - Na mesma posição.

MEC - E o que se passou na Alemanha que a gente vê nos filmes de Fassbinder? Com justificado pioneirismo também, para usar as palavras do Roberto, realizou-se plenamente um dos impulsos essenciais da ideia de engajamento. Pois o que ele mandava? Que se trouxesse a cultura desinteressada (tem cultura mais desinteressada que a filosófica?) para o comércio dos interesses comuns. Vamos, gente, vamos pensar! E no Brasil? O do ajuste filosófico do nosso número um, por força de um engajamento irrecusável e com uma retaguarda dramaticamente reduzida, encolhendo a olhos vistos. Como o Roberto (Schwarz), o Giannotti sabe muito bem que o engajamento se converteu no seu contrário. Sabe que participação assumiu uma conotação pejorativa, quase comercial. Mas, ao contrário do Roberto, pois não acredita mais no conto da carochinha da torre de marfim, acha que não há mais nada que se possa fazer a respeito. Daí imaginar, segundo alguém me disse, uma lógica da emancipação, com aspas, que não ignore, realis- ticamente, o lastro de positividade em que se transformou um engajamento que vinha de longe. Sentiram o drama?

CR - Na pele, como toda vertigem metafísica. Não seria uma ilusão imperativa? Eu me pergunto se ao Nichtmitmachen substantivo, que vocês estão atribuindo ao Roberto, não corresponderia, no caso mais agônico do Giannotti, um estado de abertura para a Faktizität, como quem encara o Destino sem perder a pose e exclama: zu Befehl, Herr Hauptmann! Posso estar enganada, mas às vezes tenho a impressão de que há um outro lado alemão pouco estudado nos filósofos uspianos. O Paulo bate talvez um pouco demais na tecla francesa, cartesiana, como se costuma dizer. Vejam vocês que ainda agora eu estava me lembrando de uma conferência do Bento Prado, a que assisti já faz muito tempo no Instituto Goethe, sobre o caráter confessional da filosofia do segundo Oswaldo Porchat. Não posso dizer que entendi tudo, acho até que quase nada, pois a temática era complexa, mas teve um trecho que me impressionou muito. A certa altura, não sei se por causa do lugar onde estava, ele disse que para o Porchat também Im Anfang war die Tat, e que, muito embora o Porchat expurgasse da ideia de vida em situação qualquer significação noturna, pois representava com efeito um tipo de homem cuja fresca energia ativa o salvava de estiolar-se sob a pálida sombra do pensamento, como o Hamlet imaginado por Goethe, o seu modo de articular filosofia e vida não deixava de acusar uma certa inclinação estetizante. Enfim, que as confissões filosóficas de seu colega apresentavam uma solução a rigor não-romântica para um problema que em si mesmo é romântico, na versão alemã mais forte do termo. 
ICC - ... são coisas nossas...

MEC - Sem diversionismos, por favor. Então: eu também senti o drama. Claro que com uma Stimmung bem diversa da experimentada pela Christine. Tanto é que na primeira ocasião voltei a consultar o Ricardo Musse a respeito. Pois ele me garantiu que a chave do problema "lógica da emancipação com engajamento" estaria com certeza no livrinho verde da nossa revolução cultural. E mais não disse, embora muito lhe tenha sido perguntado. Mas uma coisa ele deixou escapar: que quando a gente atualiza os mapas cognitivos, a governabilidade dispensa legitimidade, que aliás só atrapalha e a gente entra em rota explosiva de novo. Ah! Disse também que a posição do Giannotti era muito original e devia ser entendida como um caso de duplo muddling through.

CR - E aí, o que você respondeu?

MEC - O que a viúva do Georges Bizet disse a um sujeito que tinha achado a execução de tal peça musical um tanto "octogonal": J'allais le dire, Monsieur. Mas duvido que a Iná diga o mesmo das minhas considerações precedentes. Se ela prestou bem atenção, já deve ter reparado que vai precisar de muita retórica bolchevique para pôr em dúvida a palavra de ordem do Roberto - todos de volta para a torre de marfim - depois da defesa e ilustração do caminho oposto pelo Giannotti. Depois da resposta, se houver, terei o prazer de entregar de bandeja ao Paulo... Ei! Por falar nisso, onde anda o Professor?

CR - A viúva de Bizet diria que está pondo seu uniforme de almirante suíço!
MEC - ... terei o prazer de lhe entregar de bandeja o fio perdido e achado da conversa, perguntando-lhe se o Giannotti ajustado de hoje já pintava no filósofo dos anos 70, por exemplo, exigindo dos colegas que fossem à luta. É óbvio que esperando uma resposta imune à falácia metodológica conhecida como o movimento retrógrado do verdadeiro. É, verdadeiro mesmo, ponto. Não está dito em algum lugar que o que alguma coisa é de verdade ela só é no fim? Vai daí que continuo revirando o que a Iná me disse da exposição do Roberto Schwarz sobre o grupo do Capital: pensando bem, por que Marx, afinal? Por que não uma outra ideologia industrializante qualquer, como no caso de outros capitalismos retardatários? E continuava: se eu não fosse o que sempre fui e também me ocorresse (sabe-se lá) uma intuição original do Brasil, mil vezes Celso Furtado de $\mathrm{A}$ a $\mathrm{Z}$, que nunca foi marxista nem pretendeu ser. Pelo menos hoje estaria onde estou, do lado dos perdedores (por enquanto), mas em boa companhia.

CR - Sou a primeira a agradecer uma deixa que dará enfim ao meu editado a chance de retornar à sua narrativa de reconversão depois de ter sido vítima dos ilusionismos do teatro filosófico da Rua Maria Antonia. Ah, agora me lembrei! Era isso mesmo! Aposto que com estas mesmas palavras, era isso que o Bento achava de um prefácio interessantíssimo do Porchat (não me perguntem de qual livro, também é demais), que ele comparava justamente a um Erziehungsroman, dizendo que os Lehrjahren do filósofo uspiano reproduziam os do Wilhelm Meister do Goethe. Como estava dizendo, eu acho que nós devíamos realçar mais esse lado alemão que dá a todos eles um inconfundível ar de família. Quem sabe se não teriam sido essas afinidades eletivas que levaram o Paulo a estudar a Alemanha do Período Artístico? 
ICC - Tudo da minha terra. Bom, acho melhor dar início aos trabalhos. Muito que bem. Novamente a pedido, a última parte (espero) da moda do engajamento. Com Roberto no barco tudo vai muito bem. Ou na torre de marfim, como preferirem. Apesar do torpedo Giannotti, que também admito estar em rota explosiva, acho que minha dúvida ainda tem cabimento. Porque o Roberto é um ensaísta e muito mais politizado do que vocês imaginam. Se ele fosse apenas um escritor (vocês sabem que ele também é, e dos melhores, vocês se lembram do conto da privatização da pinguela? então!), eu nem perderia o meu tempo. Mas consideremos o maior de todos, confrontado com a sina do seu maior crítico: o mesmo autor do capítulo terra arrasada das Negativas, o mesmo Machado que, à vista da feição bárbara do progresso nacional, sublinhara sem remissão possível as virtualidades retrógradas da modernização capitalista, podia ser o Machadinho bom companheiro das famílias e academias, um craque, como diz o Roberto, no toma-lá-dá-cá do paternalismo, tudo isso ao mesmo tempo, sem maiores disparates (além do retratado na prosa de ficção) ou aflições europeias do ser dividido, nem tese nem antítese. Concordo que o Roberto, no que concerne à prosa de ensaio, está se aproximando perigosamente da perfeição, mas não é nem aspira a passar por artista (como os críticos franceses avançadinhos) com direito a não saber bem o que faz porque a própria forma se encarrega disso. E já que também não pretende, uma vez chegado lá (à perfeição de que estava falando), exercer o papel de prócer do paternalismo esclarecido, que no Brasil de antigamente podia com efeito conviver muito bem com a mais sincera militância socialista, como fica o nosso futuro candidato a Goethe?
Christine, taí uma figurinha carimbada pro seu álbum de araque. Já ouvi dizer, e também já li aqui e ali, que o Goethe vinha a ser precisamente o patrono desse arranjo: envergando seu fardamento de primeiro-ministro de um ducadozinho de nada, desses de tamanho fluminense que os personagens bufos de Büchner atravessam em menos de um dia, administrava a distribuição de favores para a numerosa clientela local, com a suprema fleuma e impecável distinção exigida como performance teatral de todo estadista, mesmo evoluindo numa corte absolutista de opereta. Entretanto, por baixo de toda essa estampa duvidosa, um desengajamento tal (já que é essa a palavra do momento) que, segundo consta, (não me peçam a fonte, vocês não acreditariam) chocava os mais próximos, como se cada serviço prestado viesse acompanhado de uma nota fiscal discriminando, item por item, todo o cardápio do tal Nichtmitmachen, presumo, pois não dá para imaginar Goethe enturmando com o que quer que seja. Mas como o nosso padroeiro da torre de marfim era poeta, não vale o exemplo.

Voltando. Não dispondo, portanto, do relativo conforto do artista, como fica então o nosso inquilino materialista da torre de marfim? Em primeiro lugar, um aviso, que aliás já foi dado, mas não custa insistir: sendo o locatário materialista, ele teve o cuidado de calcular a idade histórica do imóvel. Como vimos, uma vez concluída a Dialética do Engajamento, a torre em questão foi projetada para uma sociedade pós-catástrofe, nos termos do conhecido diagnóstico do outro Roberto, o alemão. Agora, o outro alemão, o Adorno, como é que ele entrou na conversa? Por meu intermédio é que não foi. Sendo fã incondicional do Roberto, não lhe faria uma falseta dessas. 
MEC - Pelas mãos dele mesmo, oras! Você sabe tanto como eu que no depoimento sobre a turma do Seminário do Capital ele lamentou que o progressismo linear deles não tivesse sido compensado por uma crítica da cultura de corte frankfurtiano. E que na ânsia de encontrar uma saída para o Brasil eles desperdiçaram uma chance histórica de pelo menos organizar o material para uma Minima Moralia do subdesenvolvimento. Quem será que a poderia escrever? E será que, uma vez escrita, ela poderia servir de diário de bordo ou livro de cabeceira de futuros homens públicos? Ainda mais agora que se descobriu que o Dr. Getúlio além de jogar pingue-pongue tinha vida interior... Mas o Roberto vai continuar na berlinda? Confesso que preferiria alugar o Giannotti.

CR - Calma. Pelo visto, uma coisa não vai sem a outra. Primeiro o Naphta, depois o Settembrini. Ou vice-versa? Estou confusa, não é fácil encontrar o caminho numa Montanha Mágica mais para Mantiqueira...

ICC - Agradecendo, de qualquer modo, o lembrete, já que a pergunta era retórica, peço licença para prosseguir. Muito bem: reli o livro, aproveitando para conferir a tradução brasileira, e também me aconselhei com o nosso expert em assuntos frankfurtianos e babados conexos, o Ricardo Musse. Concordo com a colega: de fato, sendo a Minima Moralia o breviário de uma implacável consciência da negatividade, nas palavras do autor, fica mesmo difícil associá-la, ainda que como simples exercício de imaginação, à necessária força positiva da vontade de superar o subdesenvolvimento, mesmo encarando os horrores deste último como um requisitório contra o mundo bárbaro gerado nas entranhas do Capital. Por outro lado, o livro é um repertório de fim de linha, ao qual teria chegado a humanidade colonizada pela mesma constelação de forças que brilharam com intensidade cristalina em Auschwitz, Hiroshima e equivalentes stalinistas. Para encurtar os debates, concedo que o argumento de aparência moral deliberadamente irônica (num momento, diga-se de passagem, em que a própria ironia pecaria por excesso de otimismo) está calçado, como se lembrou em outro momento desta conversa, num juízo discutível, porém muito bem armado sobre os rumos do capitalismo dos monopólios e o destino conjugado de sua imagem especular nas economias stalinistas de comando. E foi publicado, o que não deve ter contribuído pouco para o seu descrédito, num momento de euforia reconstrutiva em que o capital arrependido se deixava reformar. Se tudo isso é fato, acho que a chance perdida de uma Minima Moralia do subdesenvolvimento não ficou para trás, mas só agora está se apresentando. E quem pariu Mateus que o carregue, ou crie. Ou o Roberto escreve de uma vez esse memorial da nossa desagregação já velha de pelo menos uma década, ou ninguém mais. Não digo isso apenas para elogiar o nosso amigo, mas por achar que devemos passar a ele essa procuração também com o propósito político-literário de lhe tirar o sono (quem conhece a saúde dele, sabe que é missão quase impossível). De resto, não foi ele mesmo o primeiro a nos dar a pauta? Não chegamos finalmente ao fundo do poço, ainda por cima escaldados pelos espasmos anteriores? Como foi até anteontem, podemos sentar e conversar, e por certo encontrar um bom número de atenuantes ponderáveis para um frankfurtiano extraviado não se sentir tão mal na sua pele torcendo para o Brasil encontrar uma saída. Desde que o Collor mudou a agenda, está ficando cada vez mais difícil. Dar certo hoje para o Brasil 
quer dizer o quê? Acrescentar ao horror velho, de dois séculos, o horror novo que vemos todos os dias pelo mundo afora. Exagero? Não estou dizendo nada que não tenha ouvido dele mesmo, de uns tempos para cá. Vocês acham que o Adorno ficaria muito impressionado lendo a Gazeta Mercantil? Ou ainda que se deveria dar uma segunda chance à CEPAL? E se alguém lhe dissesse que num certo país, de que no máximo tivera breve notícia através de Thomas Mann, os pobres já estão comendo mais e os banqueiros estão em apuros? Se ele fosse dado a humor negro, talvez resmungasse: para quando é o incêndio do Reichstag? (As referências do homem são meio antigonas.). Mas devo acrescentar que ele diria coisa pior a nosso respeito: a frieza burguesa (uma das fórmulas favoritas dele) nos congelou a tal ponto que estará faltando com a verdade o intelectual não alinhado que descrever suas noites mal dormidas pensando nos horrores somados de que somos os campeões (juízo de antropologia histórica e não moral).

É melhor voltar ao roteiro que o Roberto está propondo. E como ele saiu na frente, melhor ele próprio mostrar o caminho. Da torre de marfim, é claro, já que a Estação Finlândia foi desativada. (O Giannotti disse que já trocou faz tempo o Palácio de Inverno pelo Banco Central: como não há mais medida objetiva, leva quem bate mais forte na mesa.). Então vamos lá, uma vez estabelecida a relativa equivalência nos respectivos fins de linha vividos pelos nossos dois autores. Antes, porém, um esclarecimento que devo à conversa com o nosso consultor, o Ricardo Musse. Ao contrário do que se pensa habitualmente, o mote da não-participação não é o fruto tardio e envenenado, digamos assim extorquido pelos enragés do movimento estudantil alemão de fins dos anos 60 a um pobre professor que apenas queria sossego para terminar o que viria a ser o seu último livro de filosofia. Daí o nó, pelo menos na cabeça de um gauchista alemão: por que filosofia, ou que nome se dê, àquele tipo de ensaísmo cerebral, e não teoria social ou crítica da economia política? Ah, tá, a prática foi adiada por tempo indeterminado? Pode ser. E enquanto esperamos exercemos o magistério? Muito bem. Então por que chamar de única praxis possível a teoria cultivada em sala de aula? Por que se é professor? Nada contra, mas então acatamos a atual divisão do trabalho? Como? O ensaio como forma em efígie pelo menos já vai rompendo diques e tabus? Ah, sim, o capitalismo venceu, dando razão a Marx? Estamos todos ligados pelo mesmo ofuscamento? E por aí vai. Como os dois lados sabiam muito bem que não havia revolução à vista, essa comédia ideológica poderia prosseguir indefinidamente numa escalada abstrata. Não é bem o momento de analisar em detalhe aquele desencontro histórico. Ou seria o caso de novo, à vista do sucedido em dezembro passado (95) na França?

De minha parte já vou avisando o nosso falso entrevistado oficial que esta conversa não acaba sem antes colocarmos em pratos limpos a tal panaceia, passepartout ou que for, do ensaísmo. Pra mim, salvo segunda ordem, é pendant literário do não fazer nada político mesmo, no máximo esperando que algo aconteça, não se sabe bem como. Uma outra curiosidade antes de fechar o parêntese: é que particularmente acho uma graça esses alemães e a inegável alta cultura teórica deles, repetindo o mesmo argumento. Aliás é menos argumento que síndrome de mandarim, desde os tempos da Revolução Francesa, que eles admiravam à distância e com desinteressado entusiasmo. Desejavam de boa fé o resultado, mas não os meios de produzi-lo, já que não se poderia esperar nada de bom, salvo mais tirania, da parte de sujeitos que não são pro- 
priamente tais sob a tutela despótica do Antigo Regime. Enfim, queriam uma revolução sem revolução, quadratura do círculo que se poderia resolver pela via combinada do despotismo esclarecido - que hoje atende pelo nome de modernização conservadora - e da educação estética dos novos sujeitos recompostos na sua integridade de entendimento e sensibilidade. Em caso de sucesso, a revolução que se antecipava a si mesma dispensava a revolução. Isto quanto à burguesa. Idem quanto à outra (a nossa, isto é, a bolchevique, para dar nome ao fantasma do século). Mesmíssima antinomia em Adorno (mas poderia ser também a balança travada entre velhos e novos desejos em Marcuse). Em tempos de teoria atrofiada e razão subjetiva formalizada, qualquer tentativa radical de transpor o fosso entre teoria e prática no capitalismo avançado é o caminho mais curto para se reproduzir o antigo horror. Mas isso não cheira à microfísica do poder parisiense? Ou é só o meu nariz que se enjoa com essas fragrâncias adocicadas? Não há de ser à toa que o bom reverendo Habermas, que queria de boa fé trazer os energúmenos da oposição extraparlamentar de volta ao espaço público da opinião a ser esclarecida pelo debate argumentado, recomendava que se distinguisse técnica instrumental, matriz da abstração ativista dos gauchistas, e ação política suscetível de ser ajuizada segundo o verdadeiro e o falso. Deu no que vem dando: o ideal de maioridade no capitalismo pós-organizado. O estrago me parece bem menor no jardim adorniano, cultivado com o adubo voltairiano do negativo. Enfim, ontem como hoje, as mesmas antinomias da revolução sem revolução que, no melhor dos casos, estilizadas, dão em ensaio e, no pior, em filosofia. Adorno alternava e, nos bons momentos, no mesmo escrito.
Tudo isso pode muito bem não ser falso, mas, para não ser injusta com Adorno é preciso lembrar que, como foi anunciado no início desta digressão, a conclusão "estou fora, não me resigno mas estou fora" não só não precisou do espetáculo do obtuso cotidiano da Alemanha Federal para ser formulada, nem do simétrico ativismo dos estudantes, mas ainda foi tomada por assim dizer no limiar da redação das Minima Moralia. E mais: que este diagnóstico fechado não abria exceção para ninguém, dentro ou fora da torre de marfim, tudo claramente registrado já nas páginas iniciais do livro, podem conferir. E por falar nisso, no artigo em pauta o Roberto avisa que a palavra engajamento não tem cor própria, que um intelectual tanto pode se engajar à esquerda como à direita e até mesmo ao centro, se o senso das proporções não advertisse que o termo engajamento é excessivo para a opção pelo centro, algo tão despropositado como ousar uma ida à pizzaria. Ledo engano. Na suprema audácia de reunir-se em torno de uma marguerita, o autor de Minima Moralia veria um lance temerário, quase suicida, pela diminuição envolvida até a entropia final, se é verdade que para o intelectual a solidão inviolável (mas o Outro não formulava as questões mais simples e fundamentais quando nas noites escuras de inverno a nevasca envolvia a cabana do pensador?) é a única forma em que ele ainda é capaz de dar provas de solidariedade. Enturmar-se, a saber, precisamente Mitmachen (se posso confiar nos meus besouros espiões), é acatar tacitamente o desumano (não em geral, é óbvio, mas depois do processo civilizatório que culminou na última guerra imperialista). Assim, o intelectual que num lance de audácia rompe sua reclusão na torre de marfim para uma ida ao cinema (não exageremos: para abrir a Folha de S. Paulo), por mais cuidado que tome, por mais 
atenção que empenhe), volta para casa (ou fecha o jornal) mais estúpido e pior. Do mesmo modo, por mais apurada que seja a efêmera sociabilidade que se tece ao redor de uma pizza (mesmo orientada segundo a mais exigente lógica da intimidade), ela já é participação na injustiça na medida em que finge ser este mundo morto (não obstante, sobretudo no caso de uma pizzaria, pleno de som e fúria) um mundo no qual ainda podemos conversar uns com os outros.

CR - Auerbach! Esses alemães são mesmo uns danados... Quero morrer com a boca cheia de formigas se esse sublime oculto numa pizza não é o caso de uma epifania que só um sermo humilis bem dosado na mescla estilística é capaz de despertar.

MEC - Periga mesmo. Mas gostaria de acrescentar um complemento que muda o sentido do que você acabou de observar na direção de sua verdadeira idade histórica. Como tudo isso se passa numa era de alienação máxima, o sublime desentranhado do disco de massa em questão, girando em falso num mundo morto em que ninguém consegue ouvir o que o outro diz, já não remete o espírito que em princípio ele deveria elevar pela percepção do incomensurável senão ao que Hugo Friedrich (um contemporâneo desses teóricos da estilística, não é, Paulo?) chamou de transcendência vazia...

\section{ICC - Por Tutatis! Filosofando de novo?}

MEC - Confesse que você estava morrendo de medo de que nós nos metêssemos a filosofar para saber se o objeto em questão seria símbolo ou alegoria, como nos velhos tempos, anos 70, Tropicalismo, cineastas malditos póscinemanovismo, o Fla-Flu Lukács x Benjamin, etc., etc. Nós não estávamos nem aí. Aliás, quem começou a dizer que o engajamento de intelectual brasileiro terminou em pizza foi o Professor Roberto Schwarz. E o Giannotti confirmou.

ICC - Mas então onde é que você queria chegar?

MEC - Uai: modesta contribuição para a epifania do Sublime. Reconheço que só me lembrei da coisa agora, mas tem tudo a ver. Não é só na França que se tagarela muito sobre o sublime. Nos Estados Unidos também (como diria a Dona Margarida). E se vocês querem saber, com menor impropriedade, pois afinal foi lá que tudo começou, a famosa lógica cultural do capitalismo avançado, dita pós-modernismo (pena que a Otília não está aqui para contar as estrepolias dos arquitetos, mas está lá, no livro dela...). Depois de ler uns escritos do Paulo sobre Ideologia Francesa e idem americana, fui tirar satisfações com o próprio (não vale a pena reconstituir o susto que levei). Ele me passou, entre outros documentos e bobagens, um paper meio antigão do Richard Rorty, arbitrando, e combinando em favor do neopragmatismo americano, o contencioso para inglês ver (o trocadilho saiu sem querer) entre ideólogos franceses e teóricos alemães da promoção Habermas. Do que li e muito conversei, acho que dá para observar o seguinte, a propósito do ponto em litígio: não é que esses franceses todos também são chegados numa não-participação? (Esquece o attentisme do Frère Jacques, Iná, aí já é muita bandeira!) É isso que deixa o sangue do reverendo Habermas em ebulição. Aqui entra o Sublime e seu principal promoter, o Dr. Lyotard, paladino do dissenso pelo 
dissenso, inimigo jurado dos consensos e outras transparências totalitárias. Neste ponto até que tem graça acompanhar os esforços de mediador desenvolvidos pelo Rorty para colocar a engenharia social no lugar tanto das meta-narrativas emancipatórias, das quais ainda haveria vestígios na modesta pragmática de base linguística dos alemães, quanto do vanguardismo temporão dos parisienses. O mais divertido é que, tentando conciliar uns e outros, compromete todos com a normalidade das prósperas democracias industriais do Atlântico Norte. Vejamos então o nicht-participar do Dr. Lyotard, segundo o seu coleguinha americano de jogos de linguagem. Sem maiores rodeios, o Rorty diz com todas as letras que infelizmente sempre achou o tipo da coisa besta essa mania de intelectual francês se considerar o sal da terra, um ser à parte, portanto, com necessidades próprias, idiossincráticas, precisando ser alimentado à base de palavras que não fazem parte do vocabulário de ninguém, enfim, atitudes inefáveis especializadas na quebra de barreiras e que tais, como pensar o impensável, testemunhar a existência do inapreensível, e assim por diante. Daí a não-participação, de preferência bem ostensiva como um cartaz luminoso, maneiras, portanto, sublimes de se desengajar, de dar a entender que os interesses e as palavras da tribo não lhes dizem respeito, tudo o que cheira à racionalidade vulgar, linguagem ordinária, etc.

Bom, qual a graça disso tudo? Como já disse, estou passando adiante o peixe que comprei, que toda essa exaltação do sublime não passa de vanguardismo requentado, de segunda mão (se é verdade, como já se falou aqui, que o capitalismo em pessoa se encarregou de dar por encerrados os tempos heroicos das vanguardas históricas, parodiando, pela eliminação mercantil da distância estética a dessublimação que elas buscavam no registro da emancipação). (Tudo certo, professor? Olhe que daqui pra frente vou resumir o combinado!). De segunda ou de terceira mão, porque remonta, defasado de uma década (a gente não pode esquecer que o Sublime do Dr. Lyotard já é expressão de sua nova dentição pós-moderna), ao gauchismo dos anos 70, quando era de bom tom desancar os agentes mais explícitos da ordem (ordem do discurso incluída, de fato a matriz de última instância de toda essa parafernália), como médicos, sobretudo psiquiatras, policiais, burocratas, etc., em suma, pessoas de modo geral incultas, já que a ideia seria ajustar a sociedade às necessidades sublimes dos intelectuais que por definição não-participam, muito embora fossem todos ativíssimos. Um star system, sob pena de extinção imediata, precisa estar sempre em movimento, não é mesmo? Qual a novidade? (Olhe lá, hein, professor! Eu vou em frente, não é essa a minha função de boi de piranha? Mas como sou um boi precavido, tenho tudo aqui anotadinho! Se alguém vier me cobrar, eu esfrego no nariz!). Pois bem, temos então dialética também do não-engajamento, o nicht-participar como profissão, profissão: vanguarda. (A lógica da mercadoria é f... mesmo.) Profissão exercida primeiro na Paris meia-oito até que a economia libidinal se transformasse em condição pós-moderna, como vimos na aula passada (Xii! Escapou, Professor, mil desculpas! Tudo bem? Então vamos lá). Claro, a profissão foi desmoralizada em solo americano. Se não me engano, o Paulo já falou um pouco a respeito, acho que no episódio do Giannotti trocando as bolas do belo e do sublime, porém pensando exatamente o mesmo que o atual mainstream, uma repartição de tarefas que lembra como um decalque a anterior divisão existencialista do trabalho. (É a mesma coisa, professor? 
Ah, sim, se metamorfoseando como uma lagarta, conforme o capitalismo vai se glamourizando? Ok.) Então, andei trocando umas figurinhas com o Paulo sobre o lado brasileiro dos americanos, mesmo puritanos e moldados por um outro padrão de colonização moderna, pelo menos até o Henry James resolver o enigma internacional da cena americana, mais ou menos (é claro que menos!) complexados como nós, diminuídos diante da Europa pela carência deles (e como!) de manners and morals, etc. Vai daí que eles também encontraram o jeito deles de barateamento ideológico, acompanhado de uma espécie análoga à nossa de sexto sentido para o fundo falso do artigo ideológico importado, que acabava entregando os pontos ao longo do processo local de aclimatação. Enfim, essa história toda que o Roberto Schwarz recontou de uma vez por todas. No caso que está interessando agora, deu-se o seguinte, se entendi direito o que o Paulo quis dizer: para escândalo dos integristas locais, Rorty e Cia. chegaram à conclusão de que o triunfo do capitalismo, não só à americana, mas em geral, havia sido tão absoluto que ele dispensava qualquer tipo de fundamentação ou justificação que recorresse a uma instância qualquer de validação transcendente (Deus, Direito Natural, Verdade, Ciência, etc.): a sociedade simplesmente se afirma sem a menor preocupação com qualquer fonte legitimadora, que só poderia ser alguma narrativa mítica (tipo Bíblia, filosofia da história, etc.), metafísica, etc. Enfim, Esclarecimento integral, Ultra-iluminismo, etc. Aqui está o achado, o luxo novo: mas não era isso mesmo a quintessência da transgressão parisiense? Uaau! Fica então inútil generalizar o estilo de vida do intelectual transgressivo para toda a sociedade, pois não há mais nenhuma Lei e assemelhados a transgredir, nenhuma Identidade Social a desconstruir. A fluidez é por natu- reza liberal. Não é mesmo extraordinário? Não enturmar jamais? Nunca apelar nem se reconhecer em algum "nós” qualquer da vida? Tudo bem, mas admita igualmente que o êxtase (ou angústia, tanto faz) do intelectual solitário, o sublime em carne e osso, não é institucionalizável (nem precisa mais, aqui, do happy end), sendo assim inócuo, porque redundante. Nestas condições, por que não o confinar ao teatrinho da vida privada? (Evitemos estrepolias tipo 68, no fundo também puro teatro). Mas assim como a subversão romântica das instituições estabelecidas (sobre coisa nenhuma, não é mesmo?) tornou-se supérflua, é justo reequilibrar a balança ideológica sugerindo aos filósofos da vida pública, Habermas e Cia., que era bom cessar, por desnecessário também, de projetar sobre o social sua obsessão puritana com o universal, já que a excentricidade do sublime privado não representa, nem pode, nenhuma ameaça ao belo espetáculo dos interesses pragmaticamente congregados. Apoteose: sob o guarda-chuva da não-participação (francesa) e da compreensão democrática das vontades (alemã), capitalismo e cultura poetizada finalmente se reencontram (reparem que o mérito da síntese, por assim dizer seu lugar natural, é todo ele americano). Pronto, falei! Missão cumprida.

CR - Isso sim que é um verdadeiro engajamento mitigado!

MEC - Pois não é mesmo? O Giannotti está reclamando de barriga cheia. Alguém precisa avisar lá que as coisas já deram certo. Tal qual os conservadores americanos fustigando o Rorty (ou os republicanos infernizando o Clinton por causa daquela mixaria de gasto social do governo americano - comparem com os gastos militares, por exemplo). Eles acham que o modernismo foi para as ruas, contami- 
nou os costumes, solapou a ética do trabalho, as pessoas perderam literalmente o senso da medida! Criou-se, enfim, uma cultura antagônica, uma espécie de espírito de não-participação organizado, quem diria! Os fundamentalistas americanos não se conformam, acham que esses pessimistas culturais não merecem nem aspirina em posto de saúde. Aí vem o Rorty e diz: calma, pessoal, essa ironia toda é estritamente privada, não é nenhuma ameaça à ordem pública, que vai muito bem, obrigada, sem ajuda de princípios ou coisa que o valha. E vejam se vocês entendem, continua ele, é justamente esse à vontade liberal que converte aquela negatividade que tanto os irrita em inestimável fator de edificação pessoal. Missão Cumprida II: a missão.

ICC - Entendi, mas lamento informar que o Adorno saiu na frente, se é que você estava pensando em complicar a vida dele. Aliás, todo apoio. E só para puxar a brasa para a minha sardinha, dizem por aí que tem muita gente dos dois lados do Reno, e nos States também, tentando juntar Dialética Negativa e Pensamento Meia-oito. Por nada não há de ser. Garanto que com Brecht o golpe não funcionaria.

MEC - Esse negócio de Adorno x Brecht é problema seu. Não tenho nada a ver com Adorno. Mal entendo de assalto de trem...

ICC - Menos mal. Pois desde as primeiras páginas da Minima Moralia ele tomou o maior cuidado para enquadrar também as possíveis ilusões do intelectual encasulado, encastelado nas trincheiras da não-participação, por motivo de colapso da civilização burguesa. Para ele, quem se recusa a entrar no jogo corre sérios riscos de tirar pro- veito de sua crítica à sociedade - a pequena superioridade que mesmo o saber negativo induz - convertendo-a numa ideologia a serviço de seus interesses privados. Só faltava acrescentar (e precisa?): mesmo quem não colabora porque não quer ser conivente pode muito bem transformar a energia negativa indispensável à secessão em combustível para uma carreira pessoal. Numa palavra: como de fato não há mais nada inofensivo, até mesmo uma implacável consciência da negatividade terá alguma coisa de lobby de si própria.

Entre parênteses. Aviso, portanto, à atual turma da ética, da existência com estilo, da reengenharia do Self, da vida como obra de arte, de preferência redigida em grego, enfim todo o povinho intelectual e demais intermediários culturais, todo mundo engajadíssimo no não-engajamento: olho na comercialização da imagem da vida reta, pois o original desapareceu de catálogo faz tempo. Outro aviso, e de graça, pois não se trata de santo da minha devoção: é muito arriscado (a quebrar a cara, é óbvio) entronizar o Adorno na condição meio desfrutável de padroeiro do novo snobismo humanístico que anda correndo mundo, se queixando de que ninguém mais sabe latim. É verdade que o Adorno cometeu a imprudência de rebater os gauchistas que lhe pediram satisfações observando que participar, nem pensar, pela simples razão de que ele sempre tomou a atividade do pensamento teórico como algo extraordinariamente próximo de suas intenções artísticas. Professor, como é? Vamos ou não vamos encarar de uma vez essa questão da mescla de ensaísmo e hibernação política calçada numa perigosa vizinhança com a forma artística autônoma? Como? No seu devido lugar? Tá bom, tomei nota e não vou deixar barato. 
Fechado o parêntese, voltemos à dialética do espírito de não-participação, organizado ou não, para já ir pondo no diário a fórmula da prezada colega que me antecedeu no expediente. (You're welcome.). Muito que bem. A chave do enigma está mais uma vez na generalização da frieza burguesa, sem a qual ninguém sobrevive no mercado. É que o esforço para não se envolver é tão exigente que acaba reproduzindo em cada impulso de retraimento os traços mesmos da indiferença bem calculada de que se quer fugir. É isso aí, a lei do valor não diz outra coisa, é um pouco a sentença de morte do intelectual na torre (que o Giannotti não nos ouça): manter-se à distância dos negócios (de toda ordem) é um luxo que só o próprio sistema que os rege permite. É por essas e outras, conclui o homem, que o intelectual fechado em sua concha permanecerá de qualquer modo tão envolvido quanto seu confrade empreendedor (no nosso caso, engajamento como empreendimento), salvo pela minúscula diferença decorrente da consciência dessa vala comum, mas já vimos que esse conhecimento também pode dar em carreira (para abusar como ele das adversativas). Em resumo, não será por aí que pegaremos a mola secreta do não-me-envolvas da Dialética Negativa, ou da crítica cultural como garrafa lançada ao mar (se isto não for Iluminismo in extremis, minha avó é bonde elétrico). Até porque, segundo me informaram meus consultores (que ainda por cima me passaram uma tradução da Suma do Wiggershaus), ao longo do entrevero de 68/69 com o movimento estudantil e a oposição extraparlamentar, imagino que com deliberado senso de humor, ao enfrentar ativistas que deveria considerar energúmenos do não-envolvimento total com as chamadas engrenagens do Sistema (que atende pelo nome de Betrieb, segundo meus assessores para assuntos frankfurtianos), Adorno se apresentou como um "empreendedor", dando expediente no Instituto, que cumpria preservar, presumo que ao lado de outras "conquistas" da República Federal, da sanha engajada de um bando de mentecaptos. A torre de marfim, então, era agora um Instituto que precisava brigar por subvenções. Arrá, hein? (Em tempo: ele não estava "resistindo" a nenhuma ditadura, não me venham com histórias).

E por falar em história me lembrei de uma, que ouvi o Bento Prado contar numa roda em que rolavam causos do 68 uspiano. Na Filosofia, Porchat e Giannotti eram contra (comissões paritárias, ocupações, enfim, todo o cardápio gauchista do momento) e manobravam conforme as suas convicções. A estratégia deles, obviamente, era proteger o Departamento de Ultramar da chienlit estudantil, etc. O quê?

MEC - O Professor está lembrando... Como? Ah! Primeiro: que de fato os estudantes não estavam nem aí. Que conhecimento dos feitos culturais da burguesia paulista, que nada! Estavam a fim de passar por cima mesmo, quebrar toda a louça. Segundo: que, no entanto, aqueles dois próceres da moderna cultura filosófica brasileira não tinham nada a temer, que reinava entre os estudantes um clima de acatamento quase total. Eram a favor do progresso, desde que a serviço de uma causa mais nobre. Simplesmente queriam menos Bergson e mais Lênin, aliás reivindicação fácil de atender e já vinha mesmo acontecendo, pois uma especialidade da casa é o vácuo histórico criado com método em torno de qualquer autor, sem preconceitos, todo mundo era de esquerda, etc.

ICC - Aí, hein? Querendo abortar a moral da minha história com dialética pra boi dormir, é? Muito bonito! 
Mas vou acabar a história assim mesmo. Vai daí, depois de semanas de marchas e contramarchas, a Faculdade sempre ocupada, ameaças de invasão, numa das tantas assembleias esbravejantes diárias, passou-lhe pelas mãos um panfleto em que os estudantes iniciavam o costumeiro ataque ao Partido dos Professores com a seguinte constatação de inegável alcance histórico-mundial: "tudo igualzinho Porchat-Giannotti”.

\section{MEC - E daí?}

CR - Ah, Maria, é simples: tudo igualzinho Porchat-Giannoti, Adorno inclusive. Esta lei histórica não admite exceções "es gibt nichts Harmloses mehr". Mas olhe que o homenzinho ainda ficaria com a última palavra: como quiser, gnädige Frau, mas tenha a bondade de reparar que, tendo desenvolvido em primeira mão a dialética do Distanzierte e do Betriebsame, não faltarei com a modéstia se me considerar, em virtude do axioma do universal dominante no princípio monadológico do indivíduo, coautor da imortal lei "tudo igualzinho Porchat-Giannotti.

ICC - Forte coisa. Mas, dado o adiantado da hora, acho melhor ir tocando rápido o serviço, mesmo porque Adorno e o mandarinato alemão, mais a nova escolástica adorniana que vem vindo por aí, salvo para efeito de implicância ou ajuste de contas, não estão me interessando a mínima. Meu negócio, como o de todos os presentes é com Roberto Schwarz. Vou resumir de novo, ou melhor, repassar a pauta até a gente reencontrar o mote que no momento parece estar interessando discutir: não fica bem para um frankfurtiano, mesmo com um pé no quintal brasileiro, por parte de Thomas Mann, torcer para o Brasil se sair bem.
Primeira glosa: passando de filial a matriz, esse arranhão relativamente grave nas normas mais corriqueiras do decoro requerido pela negatividade própria do espírito de não-participação acaba sendo, digamos, remediado pela dialética muito camarada entre o encasulado e o empreendedor. Segunda glosa, puramente virtual: retornando da matriz à filial, o referido descuido afirmativo (convenhamos, uma gafe até mesmo para um marxista ocidental) teria ao seu dispor um primeiro elenco de circunstâncias atenuantes se revisto à luz de uma dialética local, não por acaso análoga ao providencial arranjo anterior, qual seja a do "a favor" e a "do contra", identificada por Antonio Candido na tradição do pensamento "radical" brasileiro. (Como o nosso extraviado memorando começou a puxar este fio na entrevista à Teoria e Debate sobre o ajuste intelectual em curso no país, que o próprio se encarregue de desembrulhar o pacote.). Terceira, na verdade um lembrete: pela enésima vez, é preciso deixar claro que o Roberto foi o primeiro a levantar a mão e dizer "espera lá!". Mas ao dar notícia da gafe, armou um belo problema: uma coisa é a história pregressa do lapso (fazer o quê? no fundo, no fundo, estávamos todos pautados pela imagem de sucesso, vendida fácil, fácil, pela metrópole a intelectuais mal curados do velho complexo colonial), e outra, o que vem pela frente. Boa coisa não há de ser. À vista do recente papelão, me pergunto se o Roberto não anda atrás de uma torre de marfim para se esconder, meio encabulado, quem sabe por antecipação. Então, um antes e um depois, sendo que o depois é o nosso futuro próximo. Quanto ao antes, o nosso Engels aqui presente já começou a passar a limpo o passado da ligeira ilusão de seu genial amigo, apresentando-a como o avesso imperceptível (por isso mesmo) de uma série impressionante de acertos, dos quais ele seria o 
primeiro devedor confesso: talvez vocês não se lembrem da manobra sutil, interrompida apenas iniciada (pelo menos em público). Foi naquele ciclo "Teoria Crítica, etc." da Maria Antonia, na semana seguinte à fala do Roberto sobre o grupo do Capital. Vocês devem se lembrar (está no vídeo) pelo menos de como acabou. O infeliz mal encontrara o seu foco quando foi obrigado a encerrar para o fecho apoteótico - a interpretação de um samba de quadra de Bubu da Portela e Jamelão, transformado em samba-enredo por "parceiros" não-convidados sobre o tema "O proletariado é o herdeiro da filosofia clássica alemã”...

\section{MEC - Pelo Engels do Roberto?}

ICC - Mas onde é que você estava?

\section{MEC - Em Londres!}

ICC - Esquece. Mas o recado, se tivesse sido dado, seria mais ou menos este: os senhores progressistas ainda estão pasmos, agarrados a todo tipo de especulação, vinculando para bem e para mal Dependência e Presidência. Pois fiquem os senhores sabendo (ele chega a ser um pouco rude na apologia do Marx dele, sacumé?) que a vossa (a gramática idem) estupefação (desnecessário lembrar que ele estava se dirigindo a uma ínfima minoria, como se diz) teria proporções bem mais modestas não fosse o êxito do Roberto Schwarz na transposição (bem no gargarejo estava um jovem concretista dissidente que garante ter ouvido transcriação) do esquema básico da escola dependentista para o plano da crítica cultural e literária: como ele tinha sido de fato estimulado a pensar as singularidades da experiência intelectual brasileira, não como exotismo que deprime ou exalta bobamente, mas como decantação polêmica e comprometedora da cultura mundial hegemônica, pela intuição original do Brasil a que chegara o referido grupo uspiano, a saber, que as taras da malformação nacional não eram um arcaísmo residual a ser eliminado como quem se recupera de um atraso ou sai do desvio, mas parte integrante da reprodução do capitalismo em plano mundial e, nessa condição, fratura exposta da alienação contemporânea, com a maior naturalidade fez retroagir sobre a corrente vencedora da referida escola (os que com irrecusável realismo e farto apoio analítico na evidência de que havia, sim, capitalismo avançado na periferia do sistema, suplantaram estagnacionistas e maximalistas) a conclusão audaciosa a que chegara por seu lado e com recursos próprios a respeito das providências críticas a tomar, tendo em vista a cara horrenda do bicho que se podia ver do lado de cá do balcão. O brilho dessa demonstração de muitos anos e obras (não só ela, é claro, ponhamos na conta duas décadas de resistência à ditadura, descontadas as negociações de praxe numa longa guerra de posições) convenceu a todos nós, e antes dos senhores o próprio autor da proeza, que dependentista por definição não entrega a rapadura, quando na verdade, como recentemente mostrou o cientista político José Luiz Fiori, ou melhor, como vem argumentando desde julho de 94, mas só agora com mais ênfase, a teoria da dependência só é incompatível com as doutrinas liberais do comércio exterior. Quanto ao resto, variando a conjuntura, engole tudo. O largo fôlego e espectro de sua versatilidade pragmática vem justamente dessa imprecisão política congênita: daí a perplexidade em que mergulhamos todos, pelo menos no primeiro capítulo desta novela. O acerto do Roberto Schwarz mascarou de tal modo o quadro, encobrindo tão bem o ca- 
ráter afirmativo da teoria da dependência que até mesmo os raros desconfiados acabaram esquecendo inteiramente daquela maleabilidade pau para toda obra. E mais não disse por que de fato o tempo era escasso e o samba logo mandou nos chamar. Dei o recado certo, Professor?

MEC - Como? Ah, ele disse que quase tudo, que o tempo da professora também era curto. É pra você avançar logo para o segundo ponto, onde mora o xis da questão.

CR - Que é isso? Ele não fala português?

MEC - O autofalante emudeceu.

CR - Nunca vi entrevista com porta-voz. É um caso inédito de nichtmichmachen.

MEC - Deve ser o tal lado alemão oculto dos filósofos uspianos.

CR - Sei. Aposentou-se e foi pra torre.

MEC - He's lost, he has nothing to say.

ICC - Terminaram? Então é para apressar o passo? Ir direto ao ponto? Ah, é, bebé? Pois não vou cumprir! O nosso memorando licenciado nem sequer se deu ao trabalho de protocolar pedido de afastamento, e nós aqui tocando o serviço sozinhas? Qual é? Está querendo simplesmente arranjar um jeito de encerrar a conversa. Com todas aquelas dívidas acumuladas? Desse jeito também vai ter que pedir financiamento ao FMI... Tá bom, ele quer que eu conte rapidinho, ou espichadinho; como a Christine já reparou faz tempo, isso lhe é... como é mesmo?

CR-Gleichgültig.

ICC - Ele quer que eu conte como o Roberto vem expondo ultimamente o processo de liquidação da referência nacional (expondo à crítica, é claro, porém sem nenhum ofuscamento retrô).

MEC - Mas nós já falamos disso!

CR - Mal começando o segundo minuto de gravação.

MEC - E por que não ficamos por ali mesmo?

ICC - Gente, é outra coisa. O que o Roberto vem expondo é o eclipse mortal para quem aprendeu a pensar refletindo sobre as implicações do único ponto de vista à sua disposição, por contraposição polêmica à ilusão universalista (que o Mário de Andrade costumava chamar de valoreternista) de se articular diretamente com a tradição mundial, que aliás não existe em estado pronto, salvo para a nossa tribo colonial (e pós-colonial também! Sim, estou às ordens, é só marcar hora e local, mas vou avisando que sou campeã de tiro-ao-alvo em parquinho), salvo, eu dizia, para a nossa tribo de bolsistas, que por isso mesmo ainda pagam o preço cultural da irrelevância quando fantaseiam (luxo fora do alcance de quem mói no asp'ro) a respeito do ciclo encerrado das formações nacionais. É óbvio que ninguém está querendo esconder que com a mundialização do capital (nada a ver com o mito risonho e franco da aldeia global e outras bobagens antigas ou no- 
vas) o âmbito prático a que se refere a noção de "nacional" está sujeito a redefinições. Outra coisa muito diferente é não se dar por achado e varrer para debaixo do tapete (de primeiro mundo, é claro) as implicações do dia-a-dia ideológico de cada um na iniquidade das relações sociais locais (e não é que eu já estava literalmente resumindo o Roberto, conforme a encomenda?). Enfim, no que respeita ao "lugar" de cada um, se ficar o bicho come, se correr o bicho pega. (Estabelecer-se planetariamente, só mesmo os Concretos, não obstante serem os últimos nacionalistas: querem exportar até o Odorico Mendes!).

Essa a primeira parte do recadinho à toa que ficou parado no ar. Com toda a certeza havia uma segunda encomenda. Que eu lhe fizesse o pequeno favor (não seja por isso) de lembrar aos presentes que eles mesmos nada opuseram à ideia de que filosofia era mesmo coisa do passado, extinta há exato século e meio. E que a gesticulação profissional sobrante, sendo aquilo que se sabe, não por falta de talento, mas de assunto, seria no máximo objeto de um outro tipo de interesse intelectual (seja dito a favor - ou contra? - do nosso conversando que o apetite dele nesse departamento é de fato leonino). E, por fim, que também lembrasse aos presentes sobre o que vínhamos no final das contas conversando esse tempo todo, senão exatamente sobre filosofia e vida nacional. Ora, estando a segunda em estado de desmanche e padecendo a primeira da supracitada falta congênita de assunto, devendo por definição entrar em coma, no que concerne a sua condição inicial de melhoramento da vida moderna, por já não haver mais vida alguma a ser modernizada, haveriam todos de convir que seria a coisa mais razoável do mundo justamente parar de conversar sobre coisa nenhuma. O que vocês acham? Para um amador, nada mal como golpe de teatro: o golpe do exercício findo.
CR - O Heiner Müller observou uma vez que o Rio Grande do Sul parecia uma Alemanha que ficou parada no tempo. Totalmente falso não há de ser, pois não deve ser por nada que os gaúchos costumam dizer que cavalo encilhado não passa duas vezes na frente da gente.

MEC - Se o Professor (afinal, de quê, então?) está pensando em voltar com plenos poderes nos braços do povo, está muito enganado.

ICC -E mais não disse porque desistiram de lhe perguntar. 


\title{
Uma História dos Paulistas no seu Desejo de ter uma Filosofia
}

\author{
Duas entrevistas
}

I*

Folha de S. Paulo (FSP) - Como você acha que o livro Um departamento francês de ultramar vai ser recebido? Como uma história intelectual do Departamento de Filosofia, um inventário de anedotas, ou o quê? Qual será a reação dos filósofos, em especial dos "objetos" do seu livro?

Paulo Arantes (PA) - Acho muito provável que o livro caia no vazio, sobretudo nos círculos filosóficos de alto nível. Se têm razão os formadores da opinião filosófica nacional, poderei contar quem sabe com alguma compreensão da parte mais esclarecida do baixo clero. E mesmo entre os representantes do "atraso", como são denominados naquelas esferas superiores os energúmenos (na acepção exata do termo) da "filosofia brasileira", creio que haverá muito mal-entendido e nenhuma simpatia. Em dois minutos vão reparar que o antipático adjetivo "uspiano" comparece com uma irritante insistência, e concluir que no

* Entrevista concedida a Fernando de Barros e Silva e Vinicius Torres Freire, Folha de São Paulo, 6 de fev. de 1994. 
fundo estou advogando a causa da oligarquia intelectual paulista, a pior de todas, porque posa de moderna e radical. Estou esperando portanto fogo cruzado, sempre na hipótese otimista de ser lido. Não estou bancando o autor maldito não - e como poderia com um assunto tão prosaico? -, mas apenas lembrando, para começar, que o estudo da repercussão desencontrada do livro faz parte dos termos da questão.

FSP - Mas você não está se precipitando? O livro ainda nem saiu...

PA - Conheço o meu time. Além do mais acontece que na forma de artigo ou fala ocasional, até mesmo, porém cada vez menos, na forma mais respeitável de "comunicação científica em Congresso", o meu assunto vem pingando há uma década. Tempo suficiente para armazenar uma boa coleção de opiniões a respeito. Para vocês terem uma ideia, uma pequena amostra, começando pelo topo da hierarquia. Ficou logo estabelecido que eu seria o assim chamado "legítimo herdeiro" de João Cruz Costa. Nada a opor, com muita honra. Só que no meio onde me criei, Cruz Costa quer dizer: velhinho simpático, contador de piada meio debochado, sem a menor bossa ou apetite filosófico, nacionalista, historiador de coisa nenhuma, a saber, pensamento tupiniquim, como se dizia antigamente. Confirmei o acerto do prognóstico anos depois, agravando ainda mais o caso, quando publiquei um livrinho sobre Antonio Candido e Roberto Schwarz: aí já não havia mais dúvida, juntando dialética (ou coisa que o valha) com matéria brasileira refratária à conceituação filosófica, tornara-me candidato a coisa pior, a Álvaro Vieira Pinto, o padroeiro do supracitado "atraso". Mas fosse qual fosse o modelo adotado, estava era perdendo tempo, devia voltar a estudar Kant, Aristóteles, e se possível Wittgenstein, se quisesse me atualizar um pouco. Uma história do Departamento? Vá lá, mas que pelo menos respeitasse as verdadeiras dimensões do objeto. Mas como saber ao certo? Se o colega estava no momento indisposto com o dito Departamento e seu passado suspeito, era mais uma vela para um mau defunto. Acresce que estava idealizando, varrendo muita coisa para debaixo do tapete, apresentando aos mais jovens uma escolinha risonha e franca que nunca existira. E ainda por cima uma história externa, sem análise das obras, e mais, quando um ou outro fragmento de juízo crítico dava o ar de sua graça, não havia argumentação, só impressões. Quanto aos mais jovens, tanto uspianos quanto de outras denominações, parece que se chegou à seguinte conclusão: o Paulo já cumpriu com a obrigação, fez direitinho o seu doutorado sobre tema do repertório clássico, tem agora o direito de se divertir. Em suma, aposentei-me precocemente, mas em compensação deveria retribuir tamanha boa vontade servindo uma dieta bem gorda de mexericos históricos. Alguns no entanto não se conformam com o desperdício (de minha parte não me canso de agradecer-lhes a homenagem póstuma), confiando na existência de uma mola filosófica mais substantiva debaixo de toda essa petite histoire: neopragmatismo? como já ouvi uma vez. O desencontro não é menor quando cruzo com algum colega proveniente de área em que o levantamento documental é muito prestigiado: à pergunta cordial sobre o andamento da minha "pesquisa", mesmo arranhando o decoro acadêmico sou obrigado a confessar que não há pesquisa nenhuma, mal saio de casa, não sei consultar arquivos nem fazer entrevistas com remanescentes. E por aí vai. 
FSP - Pelo visto o desencontro não poderia ser maior. A que você atribui essa pequena comédia de erros?

PA - Para começar, cometi um pecado mortal, embora não tenha sido o único nem o primeiro, dando a entender que estava agora levando a sério filosofia brasileira. Vocês estão rindo, mas havia motivos históricos para a interdição. Vejam o caso da literatura, onde a tradicional preferência dada aos temas brasileiros, para estudo ou inspiração, sempre teve conotação progressista. Com a filosofia deu-se exatamente o contrário. Como renasceu em S. Paulo na condição de especialidade universitária, o sentimento oposicionista era reforçado pela mais estrita fidelidade à norma europeia, amplamente confirmado pela evidência municipal: nossos rivais eram a prova caricata de que só mesmo a direita, por inépcia e vezo apologético congênito, tomava ao pé da letra os Farias Brito e consortes. Por isso Cruz Costa conseguia exasperar todo mundo: era universitário e no entanto convidava os futuros filósofos a seguirem o exemplo de Euclides da Cunha, era de esquerda, mas apreciava os argumentos antimetafísicos de um prócer local como Clóvis Bevilácqua e, para completar, juntava-se ao Pe. Leonel Franca na caçoada dos filósofos nacionais. Não é bem este o meu caso, até porque não estou recomendando aos alunos o estudo da obra do Dr. Pereira Barreto, mas que prestem a devida atenção nos ditos e feitos de José Arthur Giannotti, Oswaldo Porchat, Bento Prado Jr., Ruy Fausto, etc. A ser assim, devia ficar mesmo incômodo manter o tabu acerca do assunto nacional. E quebrá-lo era correr o risco de más companhias. Desconcerto agravado pela minha antiga condição de profissional aplicado; tivesse estreado filosofando sobre Canudos ou a Antropofagia, a conversa seria outra e possivelmente não estaria aqui para contar a história - no que fariam bem meus professores, como aliás deverá ficar claro na leitura do livro, sem prejuízo do desfecho ainda incerto. Para concluir este ponto: não acho que seja o caso trivial do filho-família caído na vida a principal fonte do desassossego dos meus maiores. Mas reside no fato muito simples (por assim dizer) de que a enorme importância que jamais me ocorreria em sã consciência recusar-lhes não se encontra exatamente no lugar onde eles sempre imaginaram que ela estivesse - por exemplo, nas altas paragens do pensamento, onde aliás evoluem todos com natural desenvoltura, sem nada ficar devendo ao similar importado. Ora, não é que vem uma cria da casa anunciar, entre outras ninharias, que passarão à história (isto é garantido) por que souberam em boa hora favorecer a formação de uma rotina? Assim, onde se esperava com toda justiça farta distribuição de medalhas, apenas a reconstituição miúda de um processo objetivo impulsionado por uma boa dose de autoengano, a que se deve, entretanto, o primeiro momento orgânico de vida filosófica no Brasil.

FSP - Até agora você deu apenas indicações do que o livro não é. Qual o sentido da palavra formação que figura no subtítulo? É uma referência à Formação da Literatura Brasileira, de Antonio Candido?

PA - Sem dúvida, aliás um segredo de polichinelo. Em nenhum momento deixo de aludir ao fato (deveria até ter sido mais discreto, como seria do gosto do pai da ideia) de que o meu esqueminha está inteiramente apoiado na ideia de Formação que Antonio Candido, encerrando um ciclo de ensaios clássicos de interpretação do Brasil, todos eles variações dessa mesma obsessão nacional, desenvolveu 
para o caso particular da literatura brasileira, revirando de alto a baixo a interpretação do nosso passado literário, reapresentado como o vir-a-ser de uma constelação de obras, autores e público - um campo histórico de influências artísticas entrecruzadas - que na sua trajetória ia aos poucos convertendo surtos desgarrados em vida literária efetiva. Ora, se observarmos bem, veremos que estava ali, nessa apropriação crítica e muito refletida da ideia de formação pelo raciocínio literário, a chave da compreensão da evolução de conjunto da cultura brasileira. Se percorrermos um a um os principais componentes de nosso sistema cultural - e por sistema devemos entender justamente aquele nexo orgânico de produção e recepção coletiva que Antonio Candido definiu por oposição às manifestações avulsas do talento individual -, do teatro às artes plásticas, passando pela música, pelo cinema, pela arquitetura, etc. (meu problema foi saber até onde encompridar esta lista), verificaremos, com uma surpreendente regularidade, que onde os surtos inconclusivos foram a regra, anulando muito esforço intelectual acumulado, o ciclo formativo excepcionalmente completado passa a ser o prenúncio da dependência ultrapassada, graças ao surgimento de uma causalidade interna acelerando o processo de maturação do referido sistema cultural, momento em que o inevitável influxo externo passa a ser incorporado com a devida sobriedade. Estava armado o esquema de que eu precisava, o ponto de vista que tornava enfim visível o meu assunto, o lugar ocupado pela filosofia na formação e funcionamento do sistema cultural brasileiro - como era de fato muito lateral, ficava mesmo difícil enxergar alguma coisa.

Em primeiro lugar, passava a dispor, para efeito de confronto histórico e consequente apreciação crítica, de um termo de comparação privilegiado, o foco original do sistema cultural em questão, a literatura, estudada pelo mesmo Antonio Candido na sua função de princípio organizativo central de revelação e sondagem da experiência brasileira. (Por onde se vê que tenho sólidas razões para procurar a companhia dos meus amigos críticos literários, com os quais não há semana em que não aprenda alguma coisa.) Em seguida, podia afinal compreender o infortúnio de Cruz Costa, que não se devia apenas à má sorte de lidar com um material de segunda. Por mais que procurasse cotejar, para a seguir avaliar e discernir uma fisionomia mental que melhor nos exprimisse, a evolução histórica nacional e o correspondente desenvolvimento da filosofia no Brasil, ficava sempre na mesma, sempre às voltas com alguma fantasia sem proveito: é que o desejável desenvolvimento da filosofia no Brasil, dos primeiros leitores de Victor Cousin à Filosofia da Vida de um Graça Aranha, era pura e simples fantasmagoria (à qual Machado de Assis fez justiça no capítulo do Humanitismo e demais elucubrações conexas), ruminação de devoradores de livros abstrusos correndo por uma pista inexistente; um arremedo ocupando o lugar do outro, a única acumulação que havia era a de disparates (aliás nem sempre inocentes, pois ornamentavam às vezes muito jogo bruto). Ao contrário do que vinha sucedendo do lado da experiência literária, onde a natureza específica da configuração artística da realidade assegurava à sucessão das obras um mínimo de continuidade social, com a filosofia, que não era representação, mas juízo, não se passava rigorosamente nada, numa palavra, sem sair do lugar, corria por fora da formação do sistema cultural brasileiro. Há mil razões para tal anomalia (da qual herdamos algumas taras, como a falta de assunto crônica, um certo sentimento 
secreto de irrelevância, etc.) e como imagino que o nosso espaço está encolhendo, assinalo apenas uma, que aliás explica em parte a virada que me deixou de frente para a matéria bruta da minha "formação" de bolso. Ocorre que a leitura filosófica dos brasileiros não podia mesmo formar tecido, não só por evidente falta de lastro social e objeto local identificável, mas porque fazia tempo, pelo menos desde a segunda metade do século passado, era coisa de profissional, matéria que se ensina e se aprende em colégio. E por razões históricas de transformação interna que também não posso esmiuçar nesta conversa. O fato é que a cultura filosófica para funcionar tem que viver no circuito fechado de uma instituição especializada. Ora, a cadeira de Filosofia regida por um professor europeu na recém fundada Universidade de São Paulo era justamente a estufa de que tanto carecíamos. Deu-se então um disparate a que devemos nosso ganha-pão: a formação que não houve enquanto nossas cogitações filosóficas levavam vida pública, porém arrevesada, subitamente engrenou graças a um transplante organizado (um detalhe decisivo). Não de um corpo doutrinário (a ser assim, continuaríamos na mesma, na eterna ciranda da doutrina-contra-doutrina das polêmicas no Brasil velho), mas de um conjunto de métodos e técnicas intelectuais cristalizado na tradicionalíssima cultura filosófica universitária francesa.

FSP - Ainda um esclarecimento preliminar. Estamos pensando no leitor que se defronta com o título do livro, aliás sem Prefácio ou Nota Introdutória que lhe facilite a vida. Segundo consta, Um Departamento Francês de Ultramar é citação de Michel Foucault acerca dos seus colegas brasileiros da rua Maria Antonia - mas não havia aí uma óbvia ironia?
PA - Trata-se de fato de uma tirada atribuída a Foucault quando passou por aqui em 65 e fomos apresentados à Ideologia Francesa em pessoa, para surpresa nossa, filha natural do dia a dia das certezas de empréstimo de que sempre vivêramos. Todo mundo costumava citar com legítima satisfação uma observação de Goldschimdt, segundo o qual já éramos de fato um Departamento de Filosofia tão bom quanto qualquer outro similar francês de Província; ainda estávamos esperando a promoção para Paris quando Foucault completou a deixa, por certo elogiando mas com leve intenção escarninha pois Departamento de Ultramar também poderia ser alguma ilha do Caribe, e nós sabíamos muito bem (mas ele não) que por lá andava a existencialista Chiquita Bacana. Pois o título pelo menos pretende sugerir igualmente o contrário do que parece anunciar: numa muito provável e desfrutável colônia de aristocratas do nada, como diria Paulo Emílio, de fato estava se dando um caso singular de dependência cultural bem-sucedida. O livro é assim um estudo desse caso preciso, e dada a natureza do enxerto, um estudo de história intelectual comparada, pois a decantação na filial confere um direito inesperado e muito específico de opinar sobre as mazelas da matriz. Ora, custa a crer que esta inversão de perspectiva por via comparativa ainda possa ser confundida com a via de mão única do reboquismo característico do ofuscamento provinciano. A graça involuntária do trocadilho de Foucault estava na sua cegueira para o fato novo: nossa colonização estava aos poucos nos despronvincianizando, e mais, o cotejo entre metrópole e periferia, em princípio desfavorável a esta última, poderia no limite implicar uma certa desqualificação das duas. Por exemplo: graças à nossa providencial incompetência criativa em copiar, a existência paródica que vem levan- 
do o Desconstrucionismo no Brasil, depõe menos contra o apêndice local, do que contribui de forma demolidora na revelação do fundo falso do original prestigioso. Enfim, um Departamento Francês de Ultramar, visto muito de perto pode fazer sorrir, recuando-se alguns passos, é uma ameaça.

FSP - Passemos do título ao subtítulo. Nele você se refere à formação filosófica uspiana como "uma experiência nos anos 60". Deu certo? A formação se completou? Vamos ter um Machado de Assis na filosofia brasileira?

PA - Tentarei me explicar por um desvio. Achei que o primeiro estudo do livro poderia servir de prefácio - mas não a uma filosofia, como seria do meu dever, lembraria Porchat. Nele relato em primeira pessoa (com as ressalvas de praxe) justamente uma experiência de formação nos anos 60, porém na acepção mais trivial e neutra das duas palavras. Se eu fosse um pateta (nunca se sabe), tentaria sugerir ao leitor que o figurante aqui presente daquelas peripécias culturais tinha um pouco de Wilhelm Meister e outro tanto de Joaquim Nabuco, ou seja, de Gilberto Amado no Recife. Nem sombra portanto de romance alemão de educação estrelado por algum futuro medalhão brasileiro. Mas se não a tomarmos ao pé da letra, essa lembrança estapafúrdia pode ajudar a compreender um par de coisas. Acontece - desnecessário insistir - que o comparsa menor que tomou o bonde andando na exata metade dos anos 60 era mesmo um tipo bisonho, que mal discernia o que lhe ia acontecendo à volta, na sala de aula, na cultura da cidade e na marcha batida da conjuntura nacional; mas ao contrário do desfecho clássico não o reencontraremos desasnado e clarividente ao fim do périplo, longe disso, o relato se encerra na virada da década e nosso coadjuvante, passada a revelação inaugural, nunca esteve tão enganado a respeito de si mesmo como naquele momento, exatamente outubro de 1969, maduro para cumprir o preceito do doutorado na Europa. Mas não é esta a perspectiva do leitor, a única que importa: se não for presumir demais, ele verá que às costas do protagonista de uma história banal de aprendizado intelectual alguma coisa se encadeou, engrenando os mais disparatados e remotos ingredientes (do Modernismo paulista às técnicas francesas de costurar textos filosóficos), onde antes havia apenas curiosidades sem futuro, uma tradição de interesse local se articulou, tutelando, para bem e para mal, porém com a força pouco convencional de uma configuração histórica à qual se deve satisfações, as manias do talento individual posto doravante no seu devido lugar; numa palavra, agora sim, na sua acepção mais enfática e especificamente brasileira, verá (assim espero) que um verdadeiro processo de formação se completou. Assim, a "formação" a que alude o subtítulo refere-se justamente ao complexo de acertos e desacertos dessa aclimatação em recinto fechado. Restringi-me, porém, ao epílogo. Dedico um estudo à pedra fundamental lançada por Jean Maugüé na virada dos anos trinta para os quarenta, mas salto ato contínuo para a década de 60, e fico por ali mesmo. É que a tal formação, embora viesse germinando desde então - com a rotina francesa assegurada por Lívio Teixeira na História da Filosofia, Gilles-Gaston Granger na Epistemologia, o jovem Giannotti na Lógica e Filosofia Geral (era a rubrica do tempo) - de fato se precipitou e só se completou mesmo nos anos 60, aliás fortemente impulsionada por outro professor francês, Gerard Lebrun, que chegara em novembro de 1960 para ficar até meados de 66. Pois foi naquela déca- 
da acelerada e crucial que o estilo franco-uspiano de mexer com filosofia se firmou, um estilo por certo individual à procura de assunto, no que concernia aos tateios e palpites de cada um, porém coletivo no que se refere aos procedimentos básicos acumulados. Aliás também dá ideia de arremate conclusivo de um ciclo formativo a rápida sucessão das teses, o Marx de Giannotti, o Bergson de Bento Prado, o Aristóteles do Porchat - mesmo os volumes sobre Marx que Ruy Fausto vem publicando, no essencial foram todos concebidos naquele momento decisivo da história dos paulistas no seu desejo de ter uma filosofia.

Deu certo então? Completou-se a formação da filosofia brasileira? Sem dúvida, sobretudo se verificarmos que o desejo dos paulistas de ter uma filosofia finalmente realizou-se. O problema recomeça se observarmos que essa aspiração, ao ficar para trás na sua satisfação mesma, é algo que precisa ser revisto com a simpatia devida a uma realização impressionante e vulnerável - enfim, o nosso desejo já não é mais esse. Não me perguntem qual é, para onde vai o bonde da filosofia, não sou motorneiro, mas como a coisa deu certo também, posso apenas constatar que ele vai na mesma direção dos demais bondes estrangeiros de primeira linha, o circuito já é o mesmo. E se algum gênio maligno (afinal um personagem clássico) mandar avisar que, no plano internacional a que enfim acedemos, o rebaixamento de horizonte de que fugíamos parece ser a regra?

Um Machado filosófico? Ainda que fosse o caso, não seria louco de me indispor com os outros três. Entendo a analogia em que se baseia a pergunta; suponhamos que seja correta: neste caso diria que dispomos não de quatro machadinhos mas de algo mais significativo, de um Machado por assim dizer coletivo, imune à antiga velei- dade do pensamento filosófico original como penhor de maioridade.

FSP - Admitamos que a formação da filosofia brasileira, na figura de sua variante franco-uspiana e nos termos e data em que você a especificou, finalmente se completou. E agora, o que fazer?

PA - Se eu tivesse o topete de um modernista dos bons tempos dos Manifestos a três por dois, talvez saísse por aí deitando falação no seguinte teor: está inventada a filosofia no Brasil. Porém como um problema, e não como resolução de antigos complexos nacionais. Não se trata em absoluto de uma pacificação, da carreira enfim aberta ao talento especulativo que finalmente se profissionalizou graças ao paradoxal efeito despronvincianizante do enclave colonial. Volto ao ponto, se não for demais insistir: trata-se a meu ver da constituição de um conjunto a um tempo estreito e denso de obras, fórmulas e manias, com genealogia própria e alheia, queira ou não gravitando na órbita de um sistema cultural que por sua vez lhe pede contas em nome de um quadro local de contradições, constelação que ao se formar acrescenta ao antigo sentimento de irrelevância uma outra sensação de que a sondagem do primeiro poderá quem sabe pôr as coisas no seu devido lugar. A meu ver, este o resultado novo. Este o sentimento desconhecido, mesmo ou sobretudo nos anos eufóricos de 60: por exemplo, meu único sentimento naquele período era de bem-estar na cultura, uma certa sensação de bem-aventurança de que logo, logo, com muita aplicação e estudo, subiria ao céu, não ao céu das Ideias, que ninguém mais acreditava em fantasmas fora do texto, mas ao céu inteligível da Grande Dissertação. Isso posto, gostaria de 
lembrar que a dita invenção da filosofia brasileira - um resultado histórico no qual eu simplesmente esbarrei num momento de desatenção, ele mesmo uma data objetiva na história cultural do país - representa sobretudo a constituição de um ponto de vista que até então não estava disponível, ponto de vista de dois gumes, conjugados como o famoso nexo do nacional e mundial que teria articulado a linha evolutiva de nossa experiência intelectual. Desnecessário frisar, um ponto de vista crítico. Estou querendo dizer com isto que a crítica de filosofia no Brasil poderá enfim tomar pé, apoiada na mobilização de elementos os mais variados, até então invisíveis. Trocando em miúdos: não se pode mais no Brasil, sob pena de retrocesso, simplesmente abrir um livro de filosofia de autor nacional e principiar a argumentar à queima roupa, como nos tempos dos tête-à-tête de gigantes, ou mais recentemente, quando escrevíamos como se nossos leitores fossem europeus e como se pairássemos acima do meio acanhado com o qual, era óbvio, como todo mundo sabe, nada tínhamos a ver, embora ainda o dito meio teime em nos pôr chumbo nas asas. Sei que o passo não é fácil, e como não há apoio bibliográfico sobre o qual descansar, o juízo crítico pouco familiar passa por abuso historicista ou coisa que o valha.

FSP - Você não poderia dar alguns exemplos dessa crítica filosófica?

PA - Já que vocês estão insistindo e como já fiz a experiência divertida de passar por marciano, dou exemplos pessoais. Vocês já devem ter percebido que no corpo do livro o pequeno estudo sobre o Porchat discrepa do conjunto pois não se trata de uma reconstituição como as demais, mas de uma apreciação crítica sobre a atualidade de um cor- po doutrinário já constituído, aliás durante vinte e cinco anos da mais aturada meditação sobre um conjunto de temas clássicos. Como entender um projeto neopirrônico para a vida mental brasileira? Com base nos azares históricos da conformação de uma personalidade filosófica em nosso meio, um outro tanto de observações sobre o teor específico de um argumento que sem querer convergir com os ares ideológicos do tempo, procurei acompanhar o curto-circuito entre os polos da equação armada pelo autor. Seria demais por enquanto pedir compreensão.

Outra vantagem do ponto de vista da formação, desta vez do ângulo mais ostensivo de uma história intelectual. O que faria um profissional que conhece seu ofício, se convidado para apresentar comunicação em colóquio, digamos, sobre Filosofia e Literatura? Sem dúvida iria diretamente ao ponto, enfrentando, por exemplo, a atualidade bibliográfica de um contencioso para o qual os americanos, depois da invasão francesa e seu complemento alemão, criaram uma rubrica de mesa de congresso: Philosophy as/and/of Literature (ignoro se já vendem em drugstore os respectivos formulários de múltipla escolha). Na mesma honrosa contingência, só que em São Paulo (o que não muda muito, pois afinal também se trata de um centro mundial de excelência), achei que já não era mais descabido tomar o mesmíssimo problema pelo seu elo local (nem de longe o mais fraco), isto é: graças justamente à presença francesa que se sabe na formação da filosofia uspiana, acompanhando os passos correspondentes de Bento Prado Jr. nos anos 60, alcançar enfim o miolo vulnerável da Ideologia Francesa da Literatura, dela retornar à sondagem da experiência brasileira por parte de nossa melhor crítica literária, para então apreciar a gravitação de conjunto desta constelação, que tanto apanha 
localismos brasileiros como a atual coreografia da imensa província franco-americana.

O mesmo para o capítulo brasileiro do marxismo filosófico, cujas origens paulistas procurei identificar em pormenor nas intervenções de Giannotti e Ruy Fausto nos anos 60. Ora, se quiser estudar o desconcerto do pós-marxismo no âmbito da atual lógica cultural da globalização capitalista desintegradora, que os grandes pontífices da Teoria dizem tratar-se de mais uma mudança de paradigma, creio que um brasileiro, conhecedor do único ponto de apoio de que dispõe para observar o sistema que o está inviabilizando, deveria reabrir, por exemplo, os escritos do Giannotti dos últimos anos, quando um capitalismo desgovernado, desmesurado (sem medida?) atropelou-lhe a obra ontológica em andamento (uma verdadeira falta de consideração), jogando-o nos braços de outro paradigma (uma sorte). E já que ando vendo fantasmas como filosofia brasileira, estou mesmo condenado a estudar meu amigo e professor José Arthur Giannotti. Agora, quanto a saber se é por aí que vai o bonde da filosofia, são outros quinhentos.

\section{II*}

Ricardo Musse (RM) - Até que ponto a produção filosófica deste "Departamento Francês de Ultramar" escapou da propensão a vir a ser um mero apêndice da "Ideologia Francesa"?

Paulo Arantes (PA) - É melhor começar periodizando um pouco. Esse Departamento Francês é coisa do passado, foi-se o tempo da hegemonia francesa incontrastada. Hoje há para todos os gostos, dificilmente se encontrará alguma tendência internacional de relevo que não esteja bem representada entre nós. Mesmo assim ainda é significativo o número dos que acompanham o dia a dia da vida filosófica francesa, por vício ou convicção. Mas veja que esse cotidiano dos pequenos boatos universitários nem sempre cruza o caminho do star system, no caso justamente a constelação dos grandes ideólogos que desbancou a geração "existencialista" anterior.

Pois foi esse descompasso que preservou meus professores do reboquismo a que você alude, fortalecidos no seu senso do ofício pela importação providencial de uma rotina centenária. Pela qual aliás também foram moldados até a medula os tais figurões: Althusser, por exemplo, tinha tudo a ver com a epistemologia de Bachelard e Canguilhem, e quase nada com Marx. Tivesse vindo em missão para São Paulo nos anos 30 o jovem agregé Jean-Paul Sartre, a força da tradição com certeza lhe inspira-

* Entrevista concedida a Ricardo Musse, O Estado de São Paulo, 12 de março de 1994. 
ria cursos iguaizinhos aos do arqui-inimigo Brunschvicg; depois do expediente sim, poderia posar de Roquentin de bar em bar. Daí o peso decisivo dos menores. Houve época em que Goldschmidt chegou a ser considerado filósofo mais rigoroso e competente do que Sartre, que de fato andava facilitando. Pois foram justamente disparates como este que tornaram possível mexer com filosofia no Brasil sem dar muito vexame. Assim, quando Foucault apareceu por aqui em 65, já fazia tempo que todo mundo achava que era a estrutura (Lévi-Strauss) que tinha razão, e não o sujeito (Sartre). De sorte que a comoção foi grande, mas nem tanto: Giannotti fez reparos contundentes (Foucault era muito fraco em Lógica); Oswaldo Porchat e Ruy Fausto, impassíveis, quase indiferentes; apenas a imaginação flutuante de Bento Prado Jr. se acendeu, mas sem perder a compostura. Compreende-se que nas próximas viagens Foucault tenha preferido o Rio de Janeiro. Dois anos depois, o grande feito da filosofia paulista na década de 60. Com recursos próprios, mas também porta-voz de um coletivo local, Giannotti barrou a passagem do althusserismo, pelo menos na rua Maria Antonia, graças a um artigo hoje clássico e muita pancada num jovem Jacques Rancière assustadíssimo, sem compreender nada do seu papel histórico de primeira vítima da maioridade da filosofia uspiana que madrugava.

Com o tempo deu-se até uma inversão de papéis, os filósofos paulistas estavam se tornando mais realistas do que o rei. No seu desejo de ter uma vida filosófica de verdade, acabaram muito estritos na observância das boas maneiras intelectuais inculcadas pelos professores franceses em missão, um certo decoro acadêmico que os assim chamados (pelos americanos) pós-estruturalistas andavam justamente mandando às favas, trocando de fantasia a cada temporada. Com a maior sem cerimônia, Foucault, Barthes e Cia. viravam a mesa a cada livro. Mas ninguém mais por aqui estava achando muita graça nessa mágica. Não é que no momento mesmo em que finalmente os filósofos paulistas emparelhavam com o ideal europeu da continuidade orgânica na marcha das ideias, os ideólogos franceses se punham a imitar os brasileiros de antigamente? Se fosse o caso de extrapolar um pouco, está aí uma boa ocasião para se reconsiderar o destino e o caráter de nossas modernizações tardias. Assim - para dar um exemplo bem enfático -, nosso capitalismo periférico demorou quase cem anos para alcançar a Segunda Revolução Industrial, quando sobreveio a Terceira, sem que no entanto o capital nesse meio tempo mundializado dê a entender desta vez que as fronteiras tecnológicas serão estáveis o suficiente para esperar mais uma vez por nós. Ora, a engrenagem bem azeitada de um Departamento de Filosofia não era precisamente um dos últimos melhoramentos da vida moderna de que carecíamos para ingressar no concerto internacional da cultura? Não custa lembrar que o Cinema Novo desapareceu sem deixar rastro, que a moderna arquitetura brasileira envelheceu, etc.

RM - Como aferir o teor "nacional" da cultura filosófica uspiana dos anos 60? Em que medida ela se diferencia da série importada de surtos filosóficos inconclusivos que são a marca registrada da nossa produção filosófica?

PA - Acho que já abordei em parte o segundo tópico da pergunta. Na medida em que puder servir de exemplo (uma das raras vantagens da idade), acrescentaria o seguinte resumo: Bento imitava Sartre, mas passou a imitar Lebrun, que imitava Foucault, que rivalizava com Sartre; quando 
entrei na dança, já era hora de imitar Bento; não conseguindo, como era de se prever, de tanto ruminar as razões de minha inépcia acabei esbarrando no velho problema da filosofia no Brasil, que todo mundo julgava ultrapassado; eu continuava de mãos abanando, mas a peripécia não fora inconclusiva.

Quanto ao teor "nacional” da cultura filosófica uspiana nos anos 60, você mesmo acaba de me dar a deixa de que eu precisava, sugerindo que por "nacional”, numa matéria tão intangível e rarefeita como a especulação filosófica e que por isso mesmo não se presta a esse tipo de impregnação pela cor local sem descarrilar, se entenda justamente aquela primeira chance de aprender a lidar com ideias gerais estudando os tateios dos predecessores locais. Até segunda ordem, imagino.

RM - Nos anos 60, deu-se um salto na cultura filosófica uspiana. A simples exegese estrutural de textos cedeu lugar para a atitude de "filosofar por conta própria e risco". Como se deu este transbordamento do ímpeto filosófico refreado.

PA - Depois dos anos 60, você quer dizer. Preciso outra vez imaginar o capítulo que começa depois que o livro acaba. - À primeira vista, o passo rumo à doutrina filosófica própria, e se possível original, parece a coisa mais natural do mundo, uma vez encerrado oficialmente o período de assimilação criteriosa do repertório clássico. O problema, como você sabe muito bem, é que o estágio predominantemente historiográfico anterior não previa com muita clareza o movimento seguinte, parecia mesmo desaconselhá-lo, era pelo menos um convite à prudência. De qualquer modo, o fato é que lá por meados dos anos 70, a perspectiva de continuar dissertando sobre a ideia disto ou daquilo na obra de fulano ou beltrano começou a exasperar as vocações especulativas mais impetuosas. Esse retorno do reprimido deu-se basicamente segundo duas linhas de clivagem do espólio acumulado, uma voltada para dentro, outra para fora.

Mas para identificá-las melhor preciso antes recordar uma circunstância curiosa. O mal-estar na filosofia - cujos primeiros sintomas públicos começaram a se manifestar na forma de mesas redondas que giravam obsessivamente em torno das objeções tradicionais à filosofia profissional, por certo no intuito muito mal disfarçado de preparar melhor o terreno para um novo elogio da filosofia -, tem praticamente a idade política da abertura do regime militar, por assim dizer emergiu junto com aquele processo tortuoso que se espichou por dez anos, aliás dez anos de ilusões (mais os cinco de Nova República) sobre a retomada de um destino histórico interrompido, uma vez extinta a ditadura.

Onde estava Giannotti, o principal protagonista da linha de desafogo especulativo voltada para o exterior? O AI-5 o empurrara justamente para fora, mais exatamente para a fundação do CEBRAP. Estava e não estava em casa. Já não era mais o caso de retomar o Seminário do Capital, embora estivessem reunidos na mesma situação propícia de materialismo interdisciplinar alguns veteranos daquele círculo de leitura legendário. O que fazer? Deve ter dado trabalho, mas para o público interno ia conseguindo vender seu peixe filosófico na base de sempre, o arremate da fundamentação teórica. E os de fora? Aqui entram os efeitos colaterais da lembrada distensão política patrocinada pelo próprio regime. Como se há de recordar, aos poucos o CEBRAP foi se tornando o principal parceiro intelectual 
das oposições. Esteve associado à primeira vitória eleitoral de 74 e, para consumo ideológico da esquerda, forneceu os melhores argumentos para legitimar um pacto entre empresários, sindicatos e inteligência esclarecida, por assim dizer firmado depois do minigolpe que foi o pacote de abril de 77, coalizão afinal vitoriosa no Colégio Eleitoral que entronizou Tancredo. O deslizamento ideológico (ou deslize?) da Teoria da Dependência e seus correlatos políticos por esse declive deu-se sem maiores contratempos, era até natural. Mas a filosofia uspiana entregue a si mesma, onde encaixá-la nessa negociação global, nessas grandes manobras de introdução à transição vindoura? Pois foi nesse interregno - mais exatamente, entre 74 e 77, ou pelo menos a partir da brecha entreaberta nesse lapso - que Giannotti começou a bufar contra o que chamava fetichismo do texto e do comentário interminável e ao quadrado, a nos tachar de burocratas e coisas do gênero. Só que ninguém nos ensinara como passar da malha intrincada dos textos para as coisas fora do texto, até porque, tínhamos aprendido, tal passagem vinha a ser um arrematado despropósito. O próprio Giannotti não parecia dispor do mapa da mina, embora discorresse como de hábito com a ênfase do proprietário do dito tesouro (no que fazia bem, pois não podia desenganar seus comandados). Acionou então dois registros, tradicionalmente incompatíveis. No primeiro, diante de uma exigência nova, apelou para um paradigma dos velhos tempos: que voltássemos às coisas elas mesmas, como queria Husserl no início do século, só que em vez de descrever cubos, descrições fenomenológicas de mercadorias nas prateleiras de supermercados. Tarefa ingrata da qual se desincumbiu bravamente, só que ainda no terreno remoto das constituições de objeto. No outro registro, deixando provisoriamente de lado o caminho profissional das filosofias transcendentais, ressuscitava um outro projeto dos tempos em que a filosofia parecia dar as cartas, propondo que se arrumasse um jeito de fazer com que a reflexão autônoma na qual o filósofo passava por especialista (desde Kant, outra vez) engrenasse na reflexão objetiva do processo social. Lembro que era esse, sem tirar nem pôr, o programa hegeliano, e que até mesmo seus contemporâneos e jovens simpatizantes de esquerda consideravam uma providência sem dúvida genial mas que ficara inapelavelmente para trás. Mas agora importa menos esmiuçar o quadro de referências herdadas do que assinalar a obstinação em definir um lugar de primeira classe para a filosofia naquela nova conjuntura em movimento, por certo não a especialidade universitária bem conhecida, mas ainda uma filosofia primeira. Esse o nó a ser desatado: senão, como defender o direito do suposto profissional da reflexão de dar sua palavra, a última por certo, sobre os pontos na ordem do dia? (Se houver chance, retomo o tema por outra variante). Nos bons tempos do outro pacto, um pacto precursor, o nacional-desenvolvimentista, um Álvaro Vieira Pinto (mas o tal pacto já era uma fantasmagoria desde a eleição de um populista apoiado pela direita, em 1960) não precisava pensar duas vezes para afirmar que não haveria verdadeiro desenvolvimento nacional sem uma filosofia do desenvolvimento. Bem que Giannotti gostaria de dizer que não haveria transição antiautoritária, balizada por ideias claras e distintas, sem uma boa ontologia do ser social.

Vou ficar devendo o outro caminho, a guinada doméstica inaugurada no caso por Oswaldo Porchat exatamente no mesmo período. Como você publicou outro dia longos trechos de um pequeno estudo meu deste caso interessantíssimo, vou me limitar a um palpite complementar. Acho 
muito provável que a mosca dogmática tenha mordido Porchat nas mesmas circunstâncias: passado o sufoco, que também foi político, dos anos de aprendizado e abstinência, abrindo-se aos poucos as comportas, era hora de entrar em campo e justificar seu droit de regard profissional. E, como Giannotti, passou igualmente a denunciar o apego fetichista aos textos, não por acaso em favor de um retorno mais sanguíneo ao Mundo, à Vida e seus derivados.

RM - O projeto de estudar a formação de uma cultura filosófica no Brasil não estaria condenado a priori à condição de mera curiosidade pela própria irrelevância do assunto, já que se sabe que "comparada à literatura, a filosofia ocupa um lugar subalterno no panorama da cultura nacional"?

PA - Já que se sabe, vírgula. Desde quando esse lugar de primo pobre é uma evidência? E para quem? Posso garantir que pelo menos para mim não era esse o caso naqueles memoráveis anos 60. Além de não perceber nenhum sinal de desassossego nos mais velhos, meu único sentimento naquele período era de bem-estar na cultura filosófica, uma certa sensação, não de irrelevância, mas, ao contrário, da mais completa bem-aventurança. Respirava a plenos pulmões a certeza de que logo, logo, com muita aplicação e estudo, subiria ao céu, não ao céu das Ideias, que ninguém mais acreditava em fantasmas fora do texto, mas ao céu inteligível da Grande Dissertação. Isso posto, quando passei para os bastidores da grande cena especulativa nacional, não foi por considerá-la vazia (quem sou eu!) mas justamente por achar aquela gesticulação toda um assunto de primeira. Daí a encrenca em que me meti.

Passemos ao suposto lugar subalterno ocupado pela filosofia no panorama da cultura nacional. Para começar, quanto ao confronto obrigatório e desfavorável com a literatura, é preciso considerá-lo no seu devido momento. A comparação, e o juízo crítico que lhe dá sequência, só vale ao longo do período em que de fato a literatura (por todas as razões que Antonio Candido foi o primeiro a estudar) era o principal instrumento de revelação da experiência nacional, um esforço de enquadramento e formalização crucial em sociedades mal-acabadas como a nossa, enquanto a filosofia, que nos países centrais já era assunto de profissionais, entre nós ainda era esquisitice amadorística que não se sabia bem a que vinha. Uma ressalva: estou falando do ângulo muito específico e estreito da especialidade universitária vindoura; se ampliássemos o horizonte até a carreira em separado das filosofias ditas populares - positivismo, spencerismo, marxismo, etc. -, a conversa seria bem diferente e o estudo da feição amalucada que tomaram aquelas grandes máquinas ideológicas entre nós voltaria ao primeiro plano, ainda que rebaixado novamente pelo cotejo com a linha evolutiva mais consistente das obras literárias de mesma idade cultural.

As coisas começaram a mudar na esteira da Revolução de 30. Assim, a mesma incipiente divisão do trabalho intelectual que principiava a tomar corpo por exemplo na recém fundada Faculdade de Filosofia e se manifestava enfim na organização da cultura filosófica na forma de curso superior de corte europeu, começou aos poucos a aliviar o fardo do homem de letras, desobrigando-o enfim da tarefa edificante de moldar a consciência nacional. Com mais de um século de atraso, tornavam a ser contemporâneos no Brasil dois gêneros que se cristalizaram na Europa no mesmo limiar moderno, a reflexão filosófica autocentrada e ancorada numa instituição independente das tutelas 
tradicionais, e a obra de arte autônoma, regida por uma lógica imanente que em princípio não deve satisfações a nada que lhe seja estranho. Assim equiparados e depurados os dois gêneros, o antigo complexo perderia sua razão de ser.

Havia no entanto uma outra etapa a cumprir, agora no interior do processo de formação da cultura uspiana. Em tom menor o mesmo enredo se repetiria, a mesma premência na redescoberta da "realidade brasileira" voltaria a pedir contas à filosofia profissional. Mas agora o termo de comparação privilegiado eram as novas ciências sociais, que souberam herdar e atualizar o antigo espírito de missão das letras nacionais, nelas incluída a forma híbrida do ensaísmo clássico de decifração das singularidades de um país de passado colonial. Órfã de formação, a filosofia universitária era uma espécie de enxerto sem passado, condenado à retaguarda dos estudos uspianos. É preciso, entretanto, observar que ela conheceu dois breves momentos de glória: na virada dos anos 30 para os 40 quando, concentrada na figura excepcional de Jean Maugüé, esteve na origem de uma nova linhagem do ensaio crítico brasileiro; no início dos anos 60, quando por assim dizer destravou a leitura do Capital, juntando malgrado ela mesma o que por definição jamais poderia andar junto. Quis o destino ingrato, cumprindo à risca a lógica da experiência intelectual brasileira, que o novo ciclo de estudos de interpretação do país, cujo nascimento o dito Seminário direta ou indiretamente propiciou, ofuscasse novamente a pista suspensa no ar por onde corria a filosofia.

Há mais de uma década porém os ventos mudaram, uma espécie de revanche equívoca e não calculada levantou inesperadamente o ânimo da filosofia franco-uspiana, como atesta mais ou menos a partir da virada dos 70 para os 80 a demanda crescente por conversa filosófica, seja na forma de matéria impressa ou de cursos livres ou particulares solicitados pelos mais variados tipos de público, particularmente visível na presença dominante de filósofos em megaeventos culturais patrocinados por alguns órgãos públicos mais esclarecidos. Esse capítulo começa dez anos, um pouco menos talvez, depois do meu livro acabar, mas se lhe interessar posso adiantar um par de palpites sobre as circunstâncias que finalmente empurraram a filosofia para a linha de frente do consumo cultural em larga escala. - Em primeiro lugar, o colapso da teoria social. Como a modernização do país abortou (ou por outra, ela é isso que já está aí), a sociologia viu-se subitamente sem assunto, e hoje vive à míngua num debate sem fim acerca dos paradigmas em crise. Por outro lado, a desintegração que se seguiu a tal catástrofe social liberou matéria nova (ou tornou visíveis antigas) para a antropologia, que conheceu então um breve sucesso de público. Enquanto isso, nossa transição dual para lugar nenhum parece prometer a nossos amigos politólogos e economistas mais algumas décadas de minuciosa engenharia social para ajustar a economia e consolidar a democracia. Em suma, salvo engano, desde meados dos anos 70 (tirante a exortação antiautoritária) nenhum retrato novo e de corpo inteiro do país que desperte a imaginação das pessoas, como vinha acontecendo regularmente pelo menos desde o Modernismo. Portanto, lugar vago à vista pedindo para ser ocupado, só que no varejo, dado o rebaixamento geral do horizonte. Essa a chance da filosofia, mas sobretudo a da franco-uspiana (que a esta altura já é coisa naturalmente nacional), oportunidade histórica para a qual ela se preparou sem nunca ter cogitado de semelhante passo. 
Estou pensando no que ficou dos anos de auge do Estruturalismo. Na matriz parisiense, ao eclipse da philosophia perennis (à maneira do último Merleau-Ponty, por exemplo) correspondeu uma espécie de inchaço filosofante por anexação das ciências humanas que estavam mudando de pele com a maré estruturalista, da Psicanálise à Nova História (que não era assim tão nova), passando evidentemente pela Linguística e a Nouvelle Critique. Tornava-se então "filósofo" quem se mostrasse suficientemente rápido e hábil para ocupar uma espécie de terra de ninguém empregando uma costura singular de frases e noções colhidas conforme o gosto do dia naquelas disciplinas de ponta, tomando é claro o cuidado de insinuar que a dose de subversão ali era máxima, como aliás atestava a arrevesada prosa de vanguarda de que se revestia o conjunto.

Mas passemos à filial. Nossos personagens eram sérios e de boa fé, por isso ato contínuo acrescentaram à sua já pesada carga de leituras e obrigações, muito Freud e Saussure, quer dizer também Lacan (mas igualmente Ricoeur, não havia preconceitos) e Jakobson, e daí por diante. Com o tempo e as novas gerações, os mais tarimbados e maleáveis foram aprendendo a rechear as alusões, muito competentes como de praxe, aos clássicos com referências bem escolhidas no vasto elenco de conceitos herméticos em disponibilidade nas novas ciências humanas francesas. Estava enfim de pé um gênero novo, bem como um tipo intelectual inédito, porém nimbado pela autoridade ainda reconhecida da última palavra sempre reservada à filosofia, não importa o tema em pauta. Apenas um exemplo. Começaram então a proliferar anomalias do seguinte tipo: psicanalistas pedindo a filósofos que lhes explicassem certos passos intrincados de Freud, e de contrapeso, comentadores do mesmo Freud mais embrulhados (franceses, está visto). Pensando bem, um desfecho compreensível e até razoável, pois explicar um texto cuja nota dominante fosse conceitual não era o ofício mesmo do filósofo uspiano? Está claro que a virada não se resumiu a este capítulo mais circunspecto, aliás uma variante epistemológica à qual não faltarão genealogias respeitáveis. Seja como for, o fato é que o gênero em expansão foi engolindo tudo o que encontrava pela frente: erotismo, instituições políticas, música minimalista, carnaval, paixões sem interesse, histórias de todos os tipos, etc., etc. Assim, a cada nova temporada ficava comprovado o inegável tirocínio do novo personagem no trato dos temas ditos "culturais". Pois a crise global a que me referi criou também o público para esse gênero, alimentado em larga medida pelas sobras da modernização que não houve, agora em busca de novos vocabulários que ajudassem na modelagem da vida simbólica de cada um. Na hora precisa, as duas metades se encontraram e desde então a filosofia passou a ser o primo rico do campo cultural brasileiro. Como evidentemente essa transformação da filosofia não é exclusividade nacional, podemos imaginar o enredo internacional de que ela faz parte. 


\section{Crise de Paradigmas em Itaguahy*}

Fernando Barros e Silva (FBS) - Pensando nesta conversa, peguei o seu livro sobre os filósofos uspianos a procura de uma deixa. Acho que tive sorte, sorte de jornalista, pois encontrei logo no primeiro ensaio o seguinte cenário: depois de encarecer, como você mesmo diz, a fibra intelectual demonstrada por Giannotti num artigo de 1967, "Contra Althusser", você abria um parêntese para exprimir os melhores votos de que ele conservasse a mesma independência no momento de encarar a atual voga wittgensteiniana. Isso escrito por volta de 86 ou 87 , se me lembro bem. Ora, até onde estou informado, o livro sobre Wittgenstein que Giannotti está lançando no mês que vem é francamente favorável à dita corrente. Você se enganou? Giannotti cansou?

Paulo Arantes (PA) - Nenhuma uma coisa nem outra. Aquela torcida era puro fingimento, mera brincadeira de família para uma futura falsa surpresa. Todo mundo sabia que o segundo Wittgenstein, o da virada "pragmática" no âmbito das filosofias da linguagem, fazia algum tempo lhe subira à cabeça, e que o livro que cedo ou tarde viria, certamente rumaria a favor da maré, ainda que

* Entrevista concedida a Fernando Barros e Silva, Folha de São Paulo, 2 de abril de 1995, a propósito do livro de José Arthur Giannotti, Apresentação do Mundo - Considerações sobre o pensamento de Ludwig Wittgenstein, SP, Cia. das Letras, 1995. 
à maneira peculiar do seu autor. Você me dirá: mas então é fato que o Giannotti mudou, você há de convir que largar Marx por Wittgenstein pode até ser um imperativo da vida moderna, sobretudo numa sociedade considerada pós-industrial. Porém, admitida a flagrante disparidade entre os personagens, não deixa de ser uma reviravolta espetacular. Não digo que não, pelo contrário, mesmo assim não faria muito sentido cobrar-lhe fidelidade, e, ainda por cima, fidelidade a um "paradigma" envelhecido e desacreditado, o da Produção. Aliás, seria um despropósito exigir de Giannotti que ficasse parado esses anos todos: não só não ficou, como era do seu dever de filósofo atualizado, como nunca deixou de se explicar, verdade que ao seu modo encrencado de sempre. Até onde vão os meus registros, a conversão wittgensteiniana remonta a 1983, um pouco antes talvez.

Assim, Giannotti não mudou, simplesmente antecipou, tanto quanto hoje em dia um filósofo pode fazê-lo, o horizonte ideológico rebaixado em que vivemos. Pelo menos em nome da simetria e da relativa coerência que ela sugere, Giannotti poderia muito bem intitular o novo livro A favor de Wittgenstein. Nada contra, trata-se de um clássico obrigatório em qualquer curso sério de filosofia da lógica. Aí o problema: custa crer que um leitor tarimbado (ponha tarimbado nisto) do Capital venha agora nos prescrever a dieta magra da philosophia perennis (no caso em pauta, um bom exercício para sala de aula) e logo como chave mestra da crise contemporânea, quando deveria ser no máximo um sintoma entre outros, se não for simples fé de ofício na era do a favor que estamos inaugurando. - Dito isto, uma pausa para preveni-lo que ainda não li o livro indigitado.
FBS - Você está brincando! Sou um profissional sério ou pelo menos com sérias intenções neste sentido. Quer dizer que marquei uma conversa sobre um livro que você não leu?

PA - Pois é, marcou. Veja a coisa como uma homenagem a uma das principais teses sociológicas de meu antigo professor. Segundo Giannotti, vivemos tempos bárbaros onde não é mais possível distinguir os que trabalham daqueles que simplesmente fazem de conta; já num setor improdutivo como o meu, o dos serviços universitários, está cada vez mais difícil separar os que sabem dos meramente sabidos. Imagino então que seja traço distintivo dos sabidos conceder entrevistas sobre assunto desconhecido. Sem blague. Ainda não li o livro em questão, a princípio por mera casualidade, a seguir, de caso pensado, sobretudo depois que combinamos esta conversa, achando que valia a pena correr o risco de quebrar a cara ao testar meio no escuro o que imagino perceber na longa evolução do meu “objeto". No fundo, não estou arriscando grande coisa. Em primeiro lugar, porque se trata de um livro anunciado faz tempo, precedido por um ou dois artigos específicos e várias alusões estrategicamente distribuídas ao longo de intervenções em assuntos que não costumavam frequentar o antigo repertório do nosso filósofo - um livro enfim que nas rodas mais próximas já goza dessa espécie de fama antecipada própria das obras que coroam uma carreira. Em segundo lugar, porque Giannotti, como é sabido, funciona muito à base de generalização de ideias fixas, só me faltando, no caso desta última obsessão, o seu modo de apresentação. Numa palavra, um livro preparadíssimo, desconfio que embrulhado de modo a deixar os especialistas indignados e seus velhos amigos de esquerda perplexos. Além 
do mais, Giannotti não é um autor qualquer, e o livro que ainda não li por certo não será apenas o enésimo estudo de boa qualidade sobre tópicos wittgensteinianos consagrados. Os entendidos poderão até torcer o nariz, mas errarão o alvo. A companhia em que se encontra Giannotti não é bem essa. E se tudo correr bem (como espero), pode ser até que, a despeito de sua inegável cor local, a crise de paradigmas vivida por José Arthur Giannotti tenha alcance mundial.

FBS - Vá lá. Raciocinemos então por hipótese, como detestam fazê-lo políticos, empresários e técnicos de futebol. Na sua opinião Giannotti continuou o mesmo, porém mudou e muito. Como você imagina (já que não há outro recurso) a largada e o ponto de chegada dessa reviravolta com ares de confirmação, se posso definir assim o que parece uma grande manobra de reengenharia filosófica.

PA - Muito bem, arrisquemos uma hipótese, sempre na base de antecedentes conhecidos e confiáveis. Giannotti de fato continua o mesmo porém, como todo mundo, mudou de paradigma. O barateamento atual converteu a fórmula abre-te-sésamo "mudança de paradigma" numa espécie de sanção epistemológica rotineira para toda sorte de ajuste numa conjuntura cada vez menos transparente. Mesmo assim, apreciando a coisa com um pouco mais de circunspecção, mudanças de paradigma deveriam em princípio implicar, entre outros arranjos, uma longa negociação cultural. Não parece ter sido este o caso de Giannotti. Posso estar enganado, mas atravessei a década de 70 e um pouco mais sem nunca tê-lo visto dar a mínima a Wittgenstein, primeiro, segundo ou coisa que o valha, salvo é claro as referências profissionais de praxe. Esse o longo período de elaboração de seu segundo grande livro, publicado finalmente em 83, Trabalho e Reflexão. Nele tampouco qualquer alusão a Wittgenstein. Muito menos no primeiro, Origens da Dialética no Trabalho, de 1966. Evidentemente os títulos não foram dados ao acaso e sugerem mais de vinte anos de ruminação de um problema, o lugar do trabalho numa ontologia materialista do ser social.

Pois bem, sem o menor aviso prévio, deu-se então o disparate. Imagine o seguinte cenário: Trabalho e Reflexão já devia estar no prelo quando (abreviemos, para simplificar) uma alma caridosa achou que era chegado o momento de prestar um grande serviço ao desenvolvimento da cultura filosófica em nosso país chamando a atenção do Autor para o fato portentoso de que ele sem querer (aí a proeza) havia reinventado o segundo Wittgenstein, do qual aliás fazia muito tempo não se ocupava, embora não ignorasse em que direção vinha soprando o vento, mesmo nos domínios continentais tradicionalmente refratários à irradiação da filosofia anglo-americana. Os mais inquisitoriais dirão que se o meu professor caiu em tentação é porque o ovo da serpente já estava no ninho. Já os adeptos da intuição e seus derivados dirão que se trata de um caso exemplar de visão de essência. Algum espírito escarninho, habituado aos azares da profissão, lembrará em favor de nosso personagem que não há Ulisses filosófico que desconfie e resista a um canto como esse. Seja como for, podemos conjecturar sem muito erro que o dito "paradigma da produção" deve ter envelhecido trinta anos numa noite. Ocorre, no entanto, que a dose de artifício envolvido nessa virada fulminante é bem menor do que seria de presumir à primeira vista. Faça você mesmo uma expe- 
riência: ponha-se no lugar de Giannotti em 1982 (para dar uma data à visitação do tentador); reabra o livro (mas agora devidamente instruído pela boa alma que estamos imaginando) e releia as primeiras 50 ou 60 páginas (realmente impressionantes pelo esforço especulativo descomunal), dedicadas desde as primeiras linhas a tornar plausível a ideia cabeluda de abstração real, sem a qual a teoria de valor-trabalho não fica de pé, mas agora dando uma atenção maior aos exemplos, no geral curiosíssimos pela simplicidade demonstrativa. Se não estou muito enganado, além do mais falando com um antigo aluno da Filosofia, você reconhecerá meio surpreso meio divertido no exemplo pitoresco (para citar apenas um) do indivíduo que arremessa uma bola contra a parede apanhando-a de volta, depois na direção de um parceiro que a devolve sem deixá-la cair no chão, um parente inesperado dos dois pedreiros que no início das Investigações Filosóficas de Wittgenstein trocam lajotas, vigas e algumas palavras. Você vai verificar em suma que os tais "esquemas operatórios" concebidos por Giannotti para expor a articulação entre ação social governada por regras e o sistema de objetos muito originais em que um se exprime pelo outro, se assemelham a um "jogo de linguagem" como um sobrinho a um tio. Você haverá de convir então que não faltavam parentescos suficientemente estreitos para estimular o Autor que se relia depois da entrevista fatídica a pensar com os seus botões: o processo de trabalho que analisei como um esquema operatório é na verdade um jogo de linguagem, só que não verbal. De sorte que o livro ainda não havia chegado às prateleiras e Giannotti já se considerava, de papel passado e tudo, um wittgensteiniano de nascença.

FBS - Não está muito brasileira esta crise de paradigmas?
PA - Ainda não. Mas em todo o caso, para que você não fique pensando mal, achando impatrioticamente que uma crise de paradigmas entre nós não tem estofo, não se apresenta forrada de mediações, peço-lhe um esforço suplementar de imaginação, a ver se atinamos com o que de fato se passou na cabeça de nosso filósofo. De minha parte, inclino-me pelo seguinte arranjo: lá pelo fim do livro, também sem se fazer anunciar, e pela primeira vez nos escritos mais ambiciosos de Giannotti, como já foi lembrado por um comentador equivocado, mais afiados na leitura do Capital do que na crítica das formas contemporâneas do próprio, irrompe uma larga porção de realidade deste último, na forma de um curiosíssimo diagnóstico de época, de cujo teor daqui a pouco darei uma breve notícia. Assim, mais ou menos a partir da página 340, o modo de produção capitalista, que até então vinha funcionando segundo um padrão ontológico constante, sofre uma mutação estrutural de tal ordem que nem mesmo a teoria do valor resiste mais, não obstante a sólida e originalíssima fundação filosófica dela no primeiro capítulo. Considere então o panorama: num extremo, uma ontologia fundamental centrada na noção de trabalho, no outro, a explosão final da lei do valor. O que fazer? Sentindo-se desobrigado pelo referido Big-bang, creio que Giannotti resolveu salvar pelo menos o capítulo inicial, calculando que no fundo seus "esquemas operatórios" poderiam quem sabe sobreviver à falência da lei do valor. Podemos então compreender a benção que foi a revelação verdadeiramente providencial de que era um wittgensteiniano da gema. A melhor comprovação podia aliás ser encontrada numa outra construção sua, o enigmático logos prático, uma espécie de discurso objetivo tacitamente pronunciado em cada operação de troca, responsável pela transfor- 
mação de certos objetos na expressão de outros: com um pouco de boa vontade seria possível reconhecer naquele saldo do mundo-de-vida dos fenomenólogos, habilmente ajustados às significações sociais geradas pela prosa do capital, uma prefiguração dos jogos de linguagem, que por sua vez também são forma-de-vida. Sumariamente repertoriados, esses os principais peões da grande manobra, a saber: escrever um livro sobre Wittgenstein que fosse principalmente e ao mesmo tempo um grande remake do primeiro capítulo de Trabalho e Reflexão, só que agora o lugar deixado vago pelo trabalho passará a ser ocupado por uma não menos abstrusa prática reflexionante da linguagem.

FBS - Mas e se toda essa fantasia não for exata - já pensou?

PA - Se o livro não for bem assim como estou imaginando, melhor deixá-lo de vez aos cuidados dos especialistas e ver no que dá tanta ontologia injetada na pragmática do segundo Wittgenstein, como há trinta a nos atrás na Crítica marxista da Economia Política. Pelo menos este último casamento foi um erro de pessoa altamente produtivo.

FBS - Já que você está assim tão otimista, não custa confiar mais um pouco nessa implausível força explicativa da imaginação. O livro ainda continua fechado e você está sugerindo agora que ele veio tapar um buraco. Qual exatamente? Quem sabe recomeçamos pelo fim, a grande explosão, se entendi bem as idas e vindas de suas conjeturas, o cenário involuntariamente armado para a conversão wittgensteiniana de que estamos tratando.
PA - Como disse, a tal explosão ocorre lá para o fim do últimolivro, Trabalho e Reflexão. Posso lhe garantir que este eu li, não sou sabido em tempo integral. Do que se trata? Segundo Giannotti, a ela se deve a "revolução dos nossos dias", curiosamente responsável pela "barbárie" muito camarada do pós-capitalismo, pois o distinto passou desta para melhor levando a taxa média de lucro. A rigor uma crise sob encomenda, por assim dizer sob medida para os esquemas ontológicos do primeiro capítulo. Perde-se nas últimas páginas a "medida" não por acaso encontrada nas primeiras. Aliás quem perde sua real possibilidade de medida são os filhos e demais bastardos do Capital e não o filósofo, que sai ileso do combate, de quebra, de posse de uma tábua de salvação com que avaliar os acertos e desacertos da sociedade pós-industrial.

Vejamos tudo isto mais de perto, como costuma dizer o outro. Se você tiver apetite, estou certo que encontrará no referido primeiro capítulo e suas ramificações, uma das páginas mais impressionantes da literatura filosófica brasileira: num lance de grande audácia especulativa, Giannotti extrapola e converte uma analogia parcialmente estabelecida por Marx entre o processo social de medida do valor pela forma equivalente e o simples equilíbrio físico numa balança entre um pão de açucar e um peso de ferro, na matriz de uma ontologia social regida por operações lógicas elementares de identificação, que por seu turno se expandem (não sem antes passar em revista tudo que nas ciências humanas tem a ver com identidade e diferença, de Saussure a Skinner) até reencontrar o famigerado trabalho abstrato socialmente necessário, padrão de medida do valor, uma ilusão necessária que por isso mesmo não existe como ponto de referência dado, uma vez que o processo de troca mercantil cria o seu próprio 
metro ao longo do caminho, como o Giannotti gosta de dizer. Para encurtar, chamo a sua atenção para o embrião da futura encrenca, a simbiose entre a fonte da alienação (germinando na força de trabalho que só se torna coisa social reconhecida ao ser medida pelo trabalho morto que a compôs) e alguma coisa como um padrão objetivo de regulação social. Com isso, tudo se passa (na cabeça de Giannotti) como se a matriz mesma da sociabilidade capitalista retroagisse, por exemplo, até a "dádiva”, medida reguladora da sociabilidade primitiva, o "tesouro", idem para a economia de oikia, para em seguida avançar até o "fundo público", núcleo do futuro Welfarestate, hoje mal das pernas. Só mesmo um ingrato se queixaria: vivíamos sob os imperativos da ilusão (chame fetichismo se quiser), porém dispúnhamos de uma norma justificada, uma medida social realmente existente.

Ora, neste momento o mundo desaba, riscam o céu azul da boa alienação antiga os seguintes relâmpagos: transformação da ciência em força produtiva, além do mais direta e decisiva; monopolização do progresso técnico, que não se difunde mais como uma mancha de óleo; diferenciais irredutíveis, perpetuação dos lucros extraordinários e consequente implosão da perequação da taxa de lucro; segmentação do mercado de trabalho, incomensurabilidade entre os trabalhos necessariamente heterogêneos. Sem maiores considerandos, a lei do valor vai para o espaço, deixando-nos num mundo de simulacros (eu ia acrescentar pós-moderno, como pedia o clichê "simulacro", mas me lembrei que o próprio Giannotti não faz muito caso dessas periodizações, pois recua o novo estado civil do logos prático até o páleomodernismo, batizando-o de "logos prático futurista"), num mundo de falsas medidas ad hoc, em que se esfuma a distinção entre o fazer e o fazer-de-conta, o engenho e a manha, a arte e o artifício, para recorrer aos pares antitéticos de preferência de nosso Autor. Um quadro francamente disparatado: colapso ontológico do capitalismo, seguido de uma crise social das boas maneiras (ninguém mais é pontual, responde cartas, atende telefone...). Resultado: corporativismo selvagem, briga de foice pelo quinhão de cada um nos fundos públicos, etc. - como aliás se pode infelizmente perceber até nos melhores grupos de excelência. Pelo estrago na etiqueta, dá para notar que a "barbárie" em cujo ritmo vivemos (ou praticamos, se penso no meu caso de professor universitário) não se segue ao naufrágio do socialismo, mas ao declínio da "civilização", cujo apogeu, ao que parece, transcorreu durante o capitalismo concorrencial, nos bons tempos das medidas efetivas. Para você não pensar que estou simplificando além do necessário, me apresso em deixar claro que o Giannotti não mandou a lei do valor passear à maneira da ciência econômica convencional, pelo contrário, sua visível ansiedade, ou melhor, exasperação, diante do que julga ser o mundo do faz-de-conta, se deve à percepção de que a crise eclode no momento em que a lei do valor deixa de funcionar, mas num certo sentido ainda está presente, pois ele sabe muito bem que o capitalismo não subsiste sem subverter sua própria base: gostaria de apelar para ela, mas não pode mais. Numa palavra, meio aos trambolhões, esbarrara na assim chamada (por vários teóricos alemães) Crise da Sociedade do Trabalho, mas ofuscado pela obsessão da medida, encarou o fenômeno de ponta cabeça, o qual batizou de fetichismo do faz-de-conta e atribuiu ao monopólio da inovação tecnológica. Mas ao investir contra um moinho-de-vento, dará de cara com a linguagem e outra vez se enganará de fetiche. Veremos. 


\section{Post Scriptum: mudança de paradigima movida a fetichismo}

PA - Se eu fosse um bom jornalista como você, telefonaria para algum economista da velha guarda, de preferência amigo do Giannotti, e pediria uma opinião acerca desse desfecho. Imagino que você provavelmente ouviria coisas do seguinte teor. O Giannotti estava indo muito bem, pelo menos não se deixou levar na conversa do falso problema da "transformação" (do valor em preço de produção), tampouco se enredou, via Sraffa, na aporia neoricardiana do padrão invariante do valor, mas tanto insistiu (com razão) na questão da medida (do valor) que acabou deixando de lado o principal, a lei do movimento do capital (para falar em jargão daqui pra frente), cuja única finalidade é se autovalorizar, de sorte que a dita lei do valor (a menos que você a confine indevidamente no âmbito preliminar da sociedade mercantil simples de produtores independentes) só é plenamente tal ao comandar o processo de valorização do capital. Feita esta ressalva, o caminho na direção da "crise" seria outro, a propósito da qual você está pedindo minha opinião: ver como o capital, à medida em que historicamente se aproxima de seu conceito, de sua forma mais geral e aparente, vai se afastando cada vez mais da sua origem, o valor-trabalho (como isto é puro Hegel, acho que o Giannotti concordaria com prazer). Isto quer dizer (abreviando muito) que o tal ponto de chegada do processo de valorização do capital, o seu "conceito", vem a ser o capital na sua forma de valor abstrato, o dinheiro, que passa a comprar em consequência cada vez menos trabalho vivo e assim se afasta cada vez mais de sua origem, como lhe disse. Está claro que a ulterior associação entre progresso técnico e oligopólio sanciona e agrava esta úl- tima negação, o que um outro colega meu exprime muito bem: depois de relembrar pela enésima vez (nunca é demais, sobretudo nesses tempos de inocência ou euforia schumpeteriana a respeito da legião exponencialmente crescente dos inimpregáveis e inexploráveis por motivo de novo paradigma tecnológico, blá, blá, blá) que o processo "automático" de valorização do capital só é o que é por ser ao mesmo tempo um processo de desvalorização do trabalho, acrescenta, justamente numa linguagem que o Giannotti deveria apreciar (você sabe que já formamos uma grande família) que um tal sistema de produção de mercadorias tende a aniquilar sua base de valorização, isto é, a desvalorizar sua própria "medida". Sendo assim você há de convir que o amigo Giannotti deixou escapar o verdadeiro fetiche, o dinheiro (ele deveria ter observado melhor a configuração mais gritante da crise no seu início, na primeira metade dos 70), para acabar apesar de tudo hipostasiando de um lado o valor-trabalho como padrão de medida, de outro, o progresso técnico, que em si mesmo não explica coisíssima nenhuma da dinâmica do sistema, a menos que você queira mostrar, o que não era em absoluto o caso do nosso filósofo, que o desenvolvimento da técnica e o capital financeiro correm entrelaçados no atual impulso de destruição social, que a valorização do dinheiro pelo dinheiro é a imagem especular da marcha dita inexorável da inovação tecnológica rumo à esterilização total do trabalho produtivo. O big-bang? Houve sim uma explosão, só que a lei do valor, bem compreendida, como acabo de lhe explicar, continua aí sim, e bem firme, a valorização do capital continua o seu caminho, dedicada a degradar no capricho o trabalho, a ponto de torná-lo definitivamente inútil. E mais, o Giannotti deveria ficar bem menos impressionado com o estilhaçamento que se 
espelha por exemplo na criação ininterrupta de valores excepcionais se se desse ao trabalho de verificar que a tendência à igualação da taxa média de lucro também se mantém, e como! Só que agora isto se dá na forma de capital financeiro em geral. E se isto é fato, como penso, no que concerne outro fantasma dele, os trabalhos incomensuráveis que não são mais partes alíquotas da produção social, perceberíamos que o mesmo movimento do capital em escala internacional, que torna desiguais as condições de rentabilidade média do capital produtivo nas distintas regiões (não dá mais para pensar a concorrência capitalista em recinto fechado) se encarrega de unificar a taxa de lucro financeiro dos blocos de capital, de sorte que o bichão está aí funcionando a todo vapor no quadro da maldita lei, mas como ele é contraditório, essa fuga para a frente exige o estreitamento da base sobre a qual se apoia esse mesmíssimo processo de valorização. Para concluir, quando Giannotti proclama que o capitalismo hoje perdeu a sua própria medida, não digo que não, até confirmo, acrescentando apenas o essencial, a saber, que sendo o dinheiro a forma unificadora do capital, nele se refugiou o único modo pelo qual "medir" o capital, sendo assim medida dele mesmo, daí a impossibilidade real de medida, dando razão ao nosso melhor filósofo no momento mesmo de nocauteá-lo, mas fetichismo é isso mesmo. Pronto, fim de consulta.

Ou melhor, ainda não, acho que antes de desligar, esse veterano da Crítica da Economia Política não resistiria à tentação de mandar o seguinte recado. Além das lembranças, diga ao Giannotti que ele tem toda razão, que hoje em dia a trabalhos iguais (por assim dizer) não correspondem salários iguais, que de fato a técnica oligopolizada não tende mais a homogeneizar o trabalho, tende pelo con- trário a diferenciá-lo pela hierarquia (economicamente espúria, é claro), mas que, dito isto, ele não saia por aí a caçar corporativistas, sob pretexto de que são aproveitadores do "fetichismo do faz-de-conta", pensionistas do falido "paradigma da produção", desta vez não é a caça que é fetichista mas o caçador, que visa o alvo errado, o elo mais fraco do seguinte encadeamento: ao inutilizar cada vez mais trabalho vivo, o progresso técnico permite inundar o mercado com mercadorias "desvalorizadas", o que por sua vez torna necessário expandir alucinadamente os tais mercados e ao mesmo tempo, oligopolizá-los, para impedir que a mercadoria "desvalorizada" se torne enfim "livre" do valor de troca; pois a essa negação do valor-trabalho pelo lucro (que se exprime no preço politizado, cuja relação com o dito valor-trabalho é cada vez mais remota) se deve à multidão planetária dos improdutivos porém consumidores finais. Onde então o faz-de-conta? No pobre diabo que finge fazer o que deveras faz (esse o milagre que às vezes parece colocar o além-capitalismo ao alcance da mão)? Ou no fetiche do dinheiro, que ao pôr sua marca no "preço" das mercadorias põe chumbo nas asas do valor de uso prestes a levantar voo solitário a qualquer momento? Agora sim, fim da chamada a cobrar. 


\section{Ajuste intelectual*}

\section{Filosofia para todos}

Um estrangeiro não entenderia o crescente sucesso de mídia da filosofia em nosso país. E mesmo um brasileiro precisaria pensar duas vezes a respeito do espaço relativamente desproporcional ocupado pela filosofia nos meios de comunicação de massa, sobretudo em se tratando de uma especialidade tão remota como os estudos filosóficos. Nenhum jornal do mundo dedicaria quatro páginas da sua edição dominical (sem falar na inevitável réplica do concorrente) à cobertura do lançamento de um livro sobre Wittgenstein. Vocês me dirão que o autor era a verdadeira "matéria" (de capa inclusive), muito mais importante do que o clássico em questão, mas seria preciso acrescentar que o tal clássico, a despeito de ser um filósofo da lógica exigindo conhecimentos técnicos específicos, não por acaso tornou-se, nos últimos anos, matriz mundial de uma surpreendente variedade de gadgets, de filmes a biografias, passando por locais de peregrinação. Em menos de seis meses o livro já deve andar pela $2^{\mathrm{a}}$ edição. Quem o leu? Eu sou suspeito, mas não conheço muita gente.

Inexistente nos anos 60, as relações da filosofia uni-

* Material recolhido de uma conversa com Fernando Haddad e Jorge Mattos Brito de Almeida (15/16 de setembro de 1995), publicado no $\mathrm{n}^{\circ} 30$ de Teoria e Debate, revista trimestral do Partido dos Trabalhadores, nov.dez.95/jan.96. 
versitária com a indústria da consciência em nosso país datam da década seguinte. Estreamos com uma anomalia: no início dos 70, a editora Abril lança a coleção Pensadores, na forma de antologias acompanhadas de fascículos vendidos em banca de jornal, porém concebidos, planejados e coordenados por gente do ramo filosófico o mais estrito e exigente. Fora o preço, nada estava barateado. Resultado: em menos de um ano vendeu-se mais Platão do que em toda a história intelectual da Alemanha. Como era de se esperar, apocalípticos e integrados se engalfinharam. No coro frankfurtiano dos contrários falava-se em falso esclarecimento, engodo de massa, assalto à economia popular. Mas o lado a favor também possuía bons argumentos, entre eles a convicção de que era impossível tocar um primeiro ano de filosofia Brasil afora (se é fato que filosofia e espírito crítico são uma só e mesma coisa, apesar de toda desconversa que costuma acompanhar a primeira) sem o amparo de coleções como essa, além do mais numa época de universidade de massa, como já era a brasileira nos cinco primeiros anos da ditadura militar.

Primeiro lembrete a propósito de nossas esquisitices nacionais. Não custa recordar pela enésima vez que a via brasileira para o capitalismo moderno não tomou feição clássica, que em trinta anos a bem dizer passamos diretamente de uma economia primário-exportadora para uma configuração industrial oligopólica, queimando o impulso societário organizador que os países centrais devem ao longo período de capitalismo competitivo movido a luta de classes. Como este salto à frente carrega consigo uma espécie de Antigo Regime funcional, era natural que nessas condições nos tornássemos um aleijão, menos por deficiência interna do que por sermos de fato a fratura exposta do capitalismo mundial.
Se uma constelação como essa compromete até hoje a formação de um partido operário, por que não haveria de enredar num sistema de alienações originais a especulação filosófica, quando chegasse a sua hora? Esta começou de fato a chegar ao longo dos anos 70, alcançando hoje um fastígio quase burlesco. Como o país, a cultura filosófica também abandonou do dia para a noite o seu estado de "melhoramento-da-vida-moderna" para ingressar sem maiores mediações no repertório da indústria cultural, também ela muito idiossincrática em nosso meio, para pior é claro. Aliás mediações até que houve, sendo a principal delas o ânimo combativo de resistir a ditadura conferindo existência pública ao espírito filosófico. Quis, no entanto, a lógica das nossas combinações desiguais que com o tempo fosse ficando cada vez mais delicado discernir vontade de esclarecimento de exposição máxima em shows culturais, dos quais não se pode dizer sem mais que também eles não iluminem a cena. De sorte que os apocalípticos parecem integrados até o pescoço, e os integrados vez por outra cometem desatinos apocalípticos. No centro, uma Abertura bem-sucedida, que não cumprindo o prometido, melou tudo.

\section{A Universidade depois da queda}

Curiosamente, enquanto a mídia nos facilita a vida -- pelo menos os happy few que ela festeja ou tolera -- a universidade só complica. O clima é de fim de linha. Mas voltemos ao começo dela, às ilusões da Abertura, aliás ilusões com forte apoio na realidade.

$\mathrm{Na}$ virada dos anos 70 para os 80 , o mais pessimista 
dos observadores da cena nacional não recusaria o seguinte panorama, verdade que esboçado com mão de mestre: há muito tempo não se via no Brasil um esforço tão grande de estudar e entender a atualidade, conhecer e criticar os rumos do país; mas a despeito da qualidade e do empenho o conjunto não parecia somar, como se faltassem iniciativas e espaços sociais em que tais conhecimentos pudessem atravessar as barreiras de classe e profissão, influir uns nos outros, produzindo a indispensável densidade de referências recíprocas, sem as quais não se injeta energia social no estudo, transformando-o em algo mais do que simples mania ou um ganha pão como outro qualquer, em algo coletivo enfim. Em linha com esse raciocínio, e o sentimento correlato de regeneração social possível caso déssemos, entre outras coisas mais decisivas, com o nexo social entre o tal ânimo estudioso disperso e luta social, seria preciso acrescentar que o espaço das transfusões críticas demandadas estava disponível sim, como o demonstrava, por exemplo, o sucesso excepcional das reuniões da SBPC, ela mesma uma extensão da universidade (o correspondente sucesso dos megaeventos culturais de hoje, onde aliás brilha a filosofia, dá uma ideia do país depois da queda).

O mesmo autor que acabei de parafrasear costuma dizer que a universidade é uma máquina de suscitar e ao mesmo tempo anular pensamento. Pois naquela quadra, tirante a atrofia de sempre, a universidade estava mais para fomento do que para sepultamento. E isto porque vinha inchando desmesuradamente em função das políticas (e negociatas) megalomaníacas da ditadura, e quanto mais massa atendia menos funcionava. Um par de oposicionistas com muita imaginação formulou então a seguinte alternativa: se é assim, chegou a nossa hora. É que uma universidade de massa, no quadro de um processo acele- rado de modernização como o nosso, é uma peça da maior importância só que na gestão da demanda agregada, daí as flutuações irracionais do financiamento, do ponto de vista da natureza específica do objeto. Com isso era arquivado um dos grandes mitos da esquerda: salvo no que respeita à política econômica como tal, a universidade não é funcional, o capital não está minimamente interessado em ensino, pesquisa e tecnologia, até porque esta última faz tempo é gerada nos departamentos de P\&D das grandes corporações multinacionais. Vistas as coisas desse ângulo heterodoxo, percebeu-se que a ditadura tinha gerado um monstrengo libertário, um enorme exército intelectual de reserva que por razões estruturais mesmo que quisesse já era inimpregável, a não ser para fins que lesassem frontalmente os interesses mais corriqueiros do cálculo econômico. Estava ali enfim, nas salas de aula e ateliês apinhados, uma chance histórica para a descompartimentação social e intelectual que estava faltando. Como o nó vinha do inchaço burocrático e autoritário, uma vontade democrática decidida e organizada logo o cortaria. Como sabemos, as oposições também pensavam assim em plano nacional, devendo a Abertura culminar numa ruptura democrática que cuidaria de desconcentrar tanto o poder político como o econômico.

Conhecemos a reviravolta pela qual ninguém esperava. Atendendo ao mais premente de um longo ciclo recessivo, o capitalismo acabou se mundializando e inflingindo, de caso muito bem pensado, a maior derrota política e social de que se tem notícia desde os anos 30 àquelas forças que mesmo quando negociavam com ele um compromisso sabiam que estavam lidando com uma ameaça à vida civilizada no planeta. Isso dito para lembrar que a universidade não seria uma exceção. 
Quando ela se preparava para uma virada histórica foi empurrada para o cemitério das grandes carcaças deixadas pelo caminho de uma formação nacional que não se completara, ao lado de usinas nucleares que nunca funcionam, ferrovias que não levam a parte alguma, etc. -- como foi obrigado a constatar o mesmo observador esperançoso das transfusões críticas em marcha na véspera da Abertura. Daí a vida dura que levamos: mesmo assim em estado pré-falimentar de sucata, para agravo moral ainda maior, passamos por privilegiados de um setor estatal improdutivo. Não adianta discutir. Diante da grande massa de esbulhados que constituem a imensa maioria deste país, trata-se é claro de uma evidência palmar. Mesmo assim a legião dos despossuídos continuaria na mesma depois de fechada a última universidade pública brasileira.

Não é isto o mais desastroso, até porque não acontecerá. Já há muito "sabido" em campo diligenciando reengenharias, gestão profissional, parcerias (com quem, não se sabe ao certo, pois as empresas não estão nem aí, salvo um ou outro negocinho da china) e outras abobrinhas como exame final etc. A prevalecer a lógica dos vencedores, haverá encolhimentos drásticos, fatiamentos separatistas, formação de redes "acadêmicas" de interesse, etc. Modesta contribuição dos tais sabidos para o aprofundamento do processo de dessolidarização social em curso.

Como disse, não é isso o mais estarrecedor, mas o que se vê na sala de aula. Às vezes fico pensando, depois de treze anos ensinando (?) no primeiro ano, que nem mesmo cem Antonios Candidos dariam conta de tirar do limbo em que se encontram as milhares de Macabeas de ambos os sexos espalhadas pelas universidades brasileiras. Como o povo brasileiro, é certo que elas ou eles virarão estrela e irão para o céu, mas por enquanto o que se vê é outra coisa, um fenômeno para o qual o escritor e também professor Modesto Carone encontrou a fórmula exata: vítimas de um “dano cultural irreparável”. São pessoas mentalmente desmobilizadas. Não têm para onde ir, pois a parte que nos coube do ajuste conservador desativou o mecanismo básico de uma sociedade moderna, a mobilidade social ascendente, o que corta o fôlego e a vida pensante de qualquer um. Recuar, nem pensar: onde a cultura viva do povo bastando-se a si mesma? Convenhamos, não há teoria crítica que quebre o gelo de tamanha alienação sem palavras.

Desse quadro faz parte o disparate pelo qual comecei: mal-estar na universidade, relativo à-vontade na mídia. O colapso do desenvolvimento brasileiro deixou uma especialidade universitária como a sociologia, por exemplo, praticamente sem assunto. Pelo mesmo motivo, sua parceira, a antropologia, se deu muito bem, estudando os estilhaços daquela implosão, as várias maneiras dos derrotados, porém ainda dependentes do capital vencedor, entrarem e saírem da modernidade, como se diz em jargão, de preferência assistidos por corretores de "identidade" cadastrados.

Com a filosofia aconteceu algo parecido, não por acaso o seu inesperado sucesso de público seguiu de perto o da antropologia. Também ela se ocupa com as mesmas sobras. Compreende-se que numa era de violento retrocesso social, a filosofia exercida como esforço de implantação num país retardatário do item atualizador "melhoramento-da-vida-moderna" perdeu qualquer capacidade de convencimento. Como entrar numa sala de aula imbuído do propósito de difusão do espírito crítico herdado dos pais fundadores, sem resvalar no melodrama ilustrado? Sobretudo porque uma parcela dos presentes sabe que esta- 
mos vendendo outro peixe lá fora. Por uma razão muito simples: o referido desmoronamento (que tem escala mundial) ao mesmo tempo em que alterou radicalmente o perfil da demanda, transformou a filosofia numa espécie de conversa sobre cultura. Sem nunca ter pensado no assunto (nem seria possível) vínhamos nos preparando para a guinada desde a primeira época do Estruturalismo francês, quando o repertório filosófico foi ampliado, abarcando linguística, psicanálise, etnologia, nova história, neovanguarda literária, etc. Não fizemos nada também, muito pelo contrário, para desfazer a velha crendice em vigor nos meios universitários e afins de que a filosofia ainda é um tribunal de última instância, cabendo de direito ao filósofo dar a última palavra sobre qualquer assunto na ordem do dia. Ocorre que nesse meio tempo a eufemística acumulação flexível já havia se encarregado de promover o arabesco intelectual a estilo de vida que se consome, desde que devidamente animado por intermediários qualificados operando no setor. Juntar as duas metades era só uma questão de tempo e ocasião. Chegado o primeiro, a mídia fez a sua parte. Quem disse que o Iluminismo se transformaria em um engano de massa imaginou muita coisa mas não que a filosofia enquanto Crítica da Cultura seria servida por animadores culturais e congêneres. Assim, o mercado que nos fustiga por obsolescência estatal, é o mesmo que nos afaga e nos obriga a tirar coelho de cartola diante de uma plateia embandeirada por banqueiros, ministros e colunáveis.

\section{Intelectuais do contra, porém a favor}

Quanto aos intelectuais, para variar se encontram na berlinda. O que é normal em sociedades mal-acabadas como a nossa, na qual sempre foram pau pra toda obra desde os primórdios da nacionalidade. Com um dado novo a mais: um dos nossos chegou à Presidência da República, o que complica tudo. Grande parte da encrenca ideológica em que andamos metidos vem daí. Estivesse o ajuste (para empregar uma expressão chave da fraseologia em vigor) em que vivemos entalados de uns tempos para cá sendo tocado pelo cacique político de turno, estou seguro de que a conversa nacional estaria tomando outro rumo. Não quero ser cínico, pois sei muito bem quem está pagando a conta e não é hora de ficar torcendo por vida intelectual animada, mas aposto que, neste capítulo, na França de Chirac -- para irmos diretamente ao paraíso dos intelectuais -- não se passa nada, se comparado com o nosso aflitivo mal-estar na modernidade. Mas logo chegaremos lá, assim que se cumpram as promessas da grande Era do Sim que se anuncia -- Como a tendência é ser caudaloso quando o assunto em pauta é a grande e lamentável família dos intelectuais brasileiros, vou me restringir a um par de observações, melhor dizendo, a um esquema (de Antonio Candido) e seu complemento (Roberto Schwarz).

Era do Sim não é expressão minha, mas de um destacado cinemanovista saudando a sensação de vazio que experimentara logo após a vitória de Fernando Henrique. A reversão positivadora é flagrante. Embora distante no tempo, seus dois extremos integram uma mesma linha evolutiva ideológica. A famigerada marca cruel do subde- 
senvolvimento que o Cinema Novo contrapunha ao Imperialismo na forma da crítica imanente da parte ao todo, retrocedeu à condição de tara sociológica que só a racionalidade econômica saberá erradicar.

Pois bem, aí pelo fim dos anos 70, numa breve palestra ainda não recolhida em livro, Antonio Candido chamou a atenção para alguma coisa de essencial acerca desse mecanismo de reviravolta, uma constante em nossa vida intelectual. Como estamos vivendo um momento de intenso ajuste intelectual, uma rotação de eixo como há muito não se via em nosso meio até anteontem oposicionista, acho do maior interesse voltar a examinar esse esquema, a ver no que dá. Curiosamente, Antonio Candido refrescava a memória dos presentes também no momento em que a seu ver estávamos entrando numa sólida era conservadora. (No que estaria pensando, naquele fim de governo Geisel? Difícil atinar com precisão. Sendo o país aquilo que se sabe, marcado pela espantosa longevidade de posições conservadoras, ao que parece inexpugnáveis, de onde poderia vir àquela altura o agravamento em questão? No resto do mundo, de fato, os neoconservadores como se dizia então, hoje rebatizados de neoliberais, há uma década resmungavam contra a alegada ingovernabilidade do Estado keynesiano, supostamente em crise fiscal por excesso de demandas, mas Thatcher, Reagan e Cia. ainda não havia entrado em cena).

Em linhas gerais, o argumento partia da constatação de um certo déficit de negatividade em nossa cultura. Antonio Candido não se exprimiu exatamente nestes termos, mas sem falseá-lo torci um pouco a terminologia para o lado do Roberto, que me interessa salientar depois. Com isso ele queria dizer que a cultura intelectual brasileira demonstrou sempre uma tendência a ser muito "a favor", mesmo quando era "do contra". No seu modo de entender, fenômeno muito compreensível numa sociedade de cultura reflexa, condenada desde a origem a adotar os padrões trazidos pelos colonizadores. Esta referência obrigatória à norma europeia, seja para acatá-la ou infringi-la, acabou fazendo com que o "a favor" e "o contra" por assim dizer se alternassem interligados na evolução de nossa vida intelectual. Assim, um artista de vanguarda podia ser frontalmente "contra" a pasmaceira local, mas decididamente "a favor" da renovação estética europeia, que por sua vez perdia o gume negativo ao servir aos propósitos positivos de um país periférico. (Por isso é que se costuma dizer, por exemplo, que os poetas "concretos" foram de vanguarda por serem patriotas, e vice-versa). Não surpreende então que os movimentos "do contra" na cultura brasileira sejam de fato muito temperados. Entre outros casos, veja-se o de Silvio Romero: ele foi "do contra" até demais, comentava Antonio Candido, foi o campeão "do contra”, sempre "contra" a oligarquia, por exemplo, ou qualquer manifestação de grã-finismo intelectual, naturalmente aparentado à primeira, mas nem por isso menos incoerentemente "do contra" já que era "a favor" de muita coisa duvidosa, como o branqueamento do povo brasileiro. Também interessante na escalada da atitude "do contra" é o repentino desfecho "a favor", como por exemplo a espécie de ilusão ilustrada que sucede ao espasmo radical mesmo quando metodicamente conduzido, como parece ter sido o caso de um Manoel Bonfim, segundo Antonio Candido um dos homens que mais agudamente desenvolveu entre nós a mentalidade "do contra", sendo autor inclusive, no início do século, de uma originalíssima teoria do imperialismo, e nem por isso deixou de resvalar no mito muito brasileiro da redenção social pela instrução. Mais característica, 
entretanto, é a oscilação de sentido contrário, complementar do primeiro movimento, a irrupção de uma atitude "do contra" no âmbito hegemônico de irradiação da mentalidade "a favor". O caso mais notável é o do Joaquim Nabuco da campanha abolicionista, advogado gratuito da raça negra, não obstante reabsorvido pela sombra paterna findo o período "do contra". O mesmo para o Gilberto Freyre dos anos 30, investindo contra o bovarismo oficial.

Ora, sou de opinião de que se esse esquema binário fosse devidamente expandido poderia dar conta de muita coisa do ritmo ideológico característico de um certo tipo de vida intelectual congregada, de perfil institucional indeciso porém tangível, que poderíamos batizar de Partido Intelectual, cuja certidão de nascença talvez date dos efeitos políticos bem conhecidos da sociabilidade intelectual cultivada pelos árcades mineiros, alcança seu primeiro apogeu com a ilustração outorgada do período joanino, quando, na observação de um perito nestes assuntos, era difícil discernir a gratidão sincera da adulação da parte de homens cultos cujos sonhos pareciam se realizar pelo lado mais inesperado (surpresa precursora de uma outra, o espetáculo desconcertante da periferia um século e meio depois industrializando-se sob o patrocínio do imperialismo em pessoa, é claro que por sócios minoritários locais interpostos), fastígio que se repetiu depois na esteira da revolução cultural deflagrada em 30, idem na renovação do "mandato da raça negra" em versão fortemente popular do período pré-64, também acompanhada da simbiose de adulação e engajamento na forma da promiscuidade populista (na observação de outra testemunha ocular). Só para completar o parêntese que não posso esticar mais, lembraria que esse onipresente Partido Intelectual, depois de fragorosamente derrotado em
64, como que por milagre se recompôs em seguida, alcançou prontamente a hegemonia cultural no cenário adverso, partiu para o enfrentamento armado com os prepostos do capital (digamos a sua ala moça, enquanto os sêniores submergiam num exílio estudioso), mesmo esmagado se recompôs para emergir na década seguinte e firmar um pacto político (1977) cujo arco muito flexível estendia-se dos sindicatos às classes proprietárias convencidas de que a ditadura não era mais rentável; finalmente chegou ao poder intermediário dos governos estaduais (1982), tendo antes tomado o cuidado de se desfazer no meio do caminho de sua franja mais recalcitrante, a qual, não obstante abrigada por um partido de origem sindical, nunca rompeu (e como?) com a grande árvore genealógica desse partido ubíquo, afinal reinando em condomínio no comando federal desde 85 (Sarney), seguida de nova perda de lastro em 87 (colapso do Cruzado), porém nas mesmas condições de contiguidade que o desmembramento anterior, tudo culminando no coroamento de $1^{\circ}$ de janeiro de 1995.

Por mais rápido que tenha sido o sobrevoo dá para perceber, se não estou redondamente enganado, que o tal Partido Intelectual (Brasileiro e não do Brasil), sendo por definição, se tomarmos ao pé da letra a carga negativa elementar presente em qualquer esforço reflexivo, sendo portanto por definição um Partido do Contra pode muito bem funcionar como um Partido do A Favor, assim como o verdadeiro Partido da Ordem (para quem estiver lembrado do Dezoito Brumário, e da sua incrível atualidade) não precisa se contradizer nem um pouco (basta lembrar da sutil coreografia imperial executada pelo Patriarca e o Bacharel em prol de algo como um paternalismo moderno e esclarecido) para se aliar, com os atritos de praxe é claro entre os dois personagens redivivos que acabei de 
mencionar, com o dito Partido Intelectual. Em tempo: este último finalmente chegou ao poder depois de um racha minoritário e traumático, a bem dizer na boca de urna -- exagerando um pouco na data in extremis está claro, mas apenas o suficiente para lembrar que as frações deste partido quando derrotadas levam para casa o essencial do espólio herdado, e nem poderia deixar de ser assim.

Fecho o parêntese e volto ao esquema da alternância do "contra" e do "a favor" para lembrar que ele está em linha com o que Antonio Candido sempre disse, das mais variadas maneiras, a cerca da dimensão empenhada da vida intelectual brasileira, o ânimo construtivo de quem pensa e escreve com o olho posto nas providências a tomar com vistas à entrada bem aparelhada do Brasil no concerto das nações civilizadas. De sorte que exigir entre nós de um intelectual que ele se engaje é como chover no molhado, e mais uma vez assistir à mágica brasileira da conversão do negativo em positividade, ponto para o qual Roberto Schwarz não faz muito chamou a atenção, achando que finalmente chegara a hora da torre de marfim materialista. Esquema também em sintonia com outro tópico chave no arranjo teórico de Antonio Candido, o contraponto entre localismo e cosmopolitismo a reger nossa vida mental, por sua vez, embora relativamente desafogado em sua lógica específica, firmemente ancorado nas idas e vindas do campo de forças definidas pelas relações assimétricas entre centro e periferia.

Lembro o ponto para chegar à novidade que gostaria de assinalar a propósito do movimento pendular do Partido Intelectual entre o "contra" óbvio e o "a favor" não tão óbvio assim. Mas para tanto preciso recordar que o raciocínio de crítica cultural de Antonio Candido admitia e previa um momento de equilíbrio e síntese entre os dois polos, o geral e o particular, momento tanto de ordem mental quanto material: a grande hora histórica de superação do subdesenvolvimento e da dependência cultural, com a incorporação moderna e coerente das massas populares a uma sociedade de passado colonial finalmente erradicado. Acontece, como todo mundo sabe ou devia saber (pelo menos desde o seu sepultamento ostensivo com a famigerada "mudança de agenda" promovida pela era Collor) que esta hipótese começou ser derrubada a partir de 1964.

Aqui o passo adiante dado por Roberto, de que falei, e do qual já me vali quando me referi à patologia intrínseca do mundo metropolitano sendo posta em perspectiva pela atitude do "contra" do Cinema Novo. Como não posso me estender, diria muito rapidamente o seguinte: refletindo, depois do contravapor de 64, sobre o desenvolvimento do subdesenvolvimento (posso garantir que atraído muito mais pela "dialética" do título do que propriamente pelas teses de Günder Franck), quer dizer refletindo sobre a persistência do nosso Antigo Regime devidamente reposto pelo processo de aprofundamento da modernização capitalista, Roberto achou que finalmente havia chegado a hora em que a inteligência acederia objetivamente a um ponto de vista crítico de negatividade máxima acerca da marcha nefasta do capitalismo mundial, mas não um ponto de vista doutrinário qualquer, por teimosia ortodoxa e baluartista, mas uma perspectiva ancorada na sondagem das formas locais específicas daquela marcha internacional catastrófica e propriamente bárbara. Com isso, imaginava, embora não nestes termos de agora, o Partido Intelectual instalava-se de vez num longo e definitivo ciclo "do contra", em que do fundo mesmo do nosso quintal objetaríamos enfim para valer, e em nome da ex- 
periência havida, contra o sistema mundial de produção de mercadorias. E mais, um ciclo intelectual ao longo do qual nunca mais regrediríamos ao ângulo culturalmente diminuído e tutelado em que se costumava encarar a eliminação do nosso "atraso" como uma diferença a tirar em relação à normalidade (que assim deixava de sê-lo) dos países centrais.

Ora, o tempo se encarregaria de mostrar que Roberto, ao cumprir o seu dever (materialista) de crítico literário, trazendo de volta a interpretação da experiência brasileira para o centro do ensaio literário, como alguns anos antes o mesmo Antonio Candido mostrara ser possível fazê-lo, conseguira por assim dizer extrair energia estética negativa, transposta ato contínuo para o plano da crítica da cultura e da sociedade, do enfoque geral da assim chamada (para facilitar) Teoria da Dependência, mas precisara para tanto empurrar para debaixo do tapete o mais do que ambíguo caráter afirmativo dela, mais interessada em desfazer à esquerda as imagens ou imaginações equivocadas a respeito do funcionamento do capitalismo na periferia do que em criticar a cara feia do bicho (por certo achando que isto era uma obviedade moral para mais tarde, capitulação sem dúvida reforçada a cada rodada da controvérsia ideológica interna pelo acerto realista do seu diagnóstico). Associada, porém dependente, ou vice-versa, pouco importa, o fato é que nossa economia se desenvolve, nossa matriz industrial está se completando, quando chegar a nossa vez saberemos extirpar as patologias inerentes ao processo. A hora se apresentou e com ela, a conta.

Nos termos do nosso esquema: Antonio Candido (já que é o nome próprio pelo qual atende o dito esquema), mesmo derrotado no que tange à hipótese da construção nacional, compartilhada aliás por outro vencido, Celso Furtado, volta a ter razão, não sem paradoxo, seja dito para aguçar o sentimento dos contrários nesta marcha arrevesada das coisas, pois estamos evocando o testemunho involuntário de dois eminentes próceres civilizadores do mais positivo "a favor" institucional, sendo no entanto o primeiro deles declaradamente socialista e amigo fiel da Revolução Cubana. É que naquele caráter afirmativo da ideia nem um pouco equivocada de desenvolvimento capitalista dependente-associado ressoava novamente a batida do pêndulo do "a favor". Houve um interregno, é claro, em que as miragens da Abertura e da Transição arquivaram como velharia as antigas teorias da dependência, aliás reforçando a ilusão retrospectiva de que elas eram, todas, intrinsecamente críticas. O que se viu e se está vendo é que a mundialização em curso, como já foi dito por um observador dissidente, trouxe de volta consigo uma Novíssima Dependência, só que agora devidamente maquiada por uma velha racionalização encobridora. É que retornou tal qual a antiga síndrome do "Brasil errado", na contramão, no desvio, etc., seguida da palavra de ordem da faxina interna e tudo o mais que se segue da atual fraseologia da inserção internacional e seus derivados.

Preciso acrescentar que Roberto não só reconheceu a guinada (ou a explicitação em nova chave) como passou prontamente a conceituá-la, identificando, que eu saiba pela primeira vez, a dimensão industrializante do marxismo uspiano, o seu lado de progressismo burguês oitocentista, sem embargo da intuição original do Brasil de passado escravista-burguês, o maior feito do dito marxismo. Lembrando, por outro lado, que a tese da luta pela competitividade da indústria brasileira, encampada pelas duas facções rivais do que estamos chamando de Partido 
Intelectual (a que levou e a que ficou a ver navios, sem prejuízo da generosa raiva popular de que está possuída), na medida muito elementar em que qualquer sucesso regional numa situação de concorrência global de vida e morte acarreta um desastre de igual monta noutro canto do planeta, observando enfim que tal tese tem muito a ver com a estilização de uma corrida de ratos e nada a ver com a cultura de negatividade em alta de que tanto carecemos numa Era do Sim. Etc.

Antonio Candido voltaria a repisar que o "contra" do intelectual brasileiro nunca se apresenta desacompanhado do seu par alterno do "a favor". Aliás, como seu ex-assistente mostrou muito bem, e deu a última volta na chave de toda esta novela, no andamento binário da narração machadiana. E mais, recordando que os arrancos da nossa tradição "radical" intermitente (mas não os estou ameaçando com uma digressão sobre esta tradição "radical" segundo Antonio Candido, até porque não estamos falando de outra coisa desde o início), que os espasmos "do contra", de fôlego longo ou curto, cedo ou tarde retornam ao regaço da elite senhorial do "a favor". Com o que Roberto concordaria no ato, observando além do mais que as novas clivagens locais operadas pelo capitalismo mundializado geraram um bloco de "capacidades" (no sentido pejorativo que a literatura francesa antiburguesa do século passado emprestava a esta expressão), do qual queira ou não faz parte toda a crista do país organizado e integrado nos novos parâmetros produtivos (câmaras setoriais inclusive, mesmo que momentaneamente postas de escanteio) e que neste complexo das "autoridades" são todos "a favor" de que o Brasil de algum modo se saia bem (desde que outros menos dotados se ferrem), sem excluir deste propósito positivo os que agora correm por fora no pelotão “do contra”. O mesmo Roberto recordaria enfim que a oscilação histórica dos intelectuais brasileiros entre o "contra" e o "a favor" em torno do eixo ao que parece incontrastável do conservadorismo nacional se deve à margem absurda e antissocial de liberdade de que gozam nossas classes dominantes por um espécie de direito histórico aberrante derivado da origem moderna delas, criaturas escravistas do capital comercial, com um pé confortavelmente instalado na iniquidade colonial ainda viva e outro fincado à larga no polo internacional e ultramoderno dessas mesmas relações sociais horrendas, sendo aliás (mas agora sou eu que leio assim o que Roberto escreveu com muito mais precaução ao fim de seu depoimento sobre o Seminário Marx da Faculdade de Filosofia da rua Maria Antonia), sendo aliás esse impressionante leque de opções de que dispõem que lhes permitiu refuncionalizar o principal representante público de nossa cultura sociológica "do contra", apanhado num momento de desatenção em que a conjuntura internacional lhe parecia sugerir que já estava chegando a hora do “a favor”, é claro que por incontrolada paixão pelo possível e aversão não menos categórica à síndrome colonial da fracassomania, espécie de atitude "do contra" em estado crônico.

De minha parte, aproveitaria a ocasião para acrescentar que, se dispomos de fato de um Partido Intelectual de longa tradição e relevantes serviços prestados à nação, verdade que hoje rachado numa imensa maioria de ajustados e um pequeno número de desajustados, intelligentsia mesmo, na acepção russa do termo, algo como um espírito de contradição organizado sem um momento sequer de descuido afirmativo, isso com certeza jamais conhecemos. Quem sabe se ela não estaria prestes a nascer agora que o capital também nos desobrigou de sermos "a favor" 
de uma saída para o Brasil, já que nos colocou na vanguarda da desintegração mundial (afinal afundamos dez anos antes do socialismo real), com isso apressando a secessão definitiva de nossas elites "ocupantes" (para voltar a falar como Paulo Emílio Salles Gomes, agora com toda razão).

\section{Presidência simulada}

FHC? Levemente decorativo, na acepção materialista do termo. Não fui o primeiro a ter esta impressão, mas sou desta opinião. Aliás ela se encontra muito bem exposta numa entrevista recente do professor José Luiz Fiori, e ganharíamos todos em pensar duas vezes a respeito, sobretudo nos setores de esquerda com projetos presidenciais. O juízo não é leviano, nem ele quis dizer que o Presidente da República seja zero à esquerda -- a rigor a fórmula zero à esquerda exprime muito melhor a situação em que todos nós nos encontramos, à esquerda. Ocorre, para retomar o argumento resumido na referida entrevista, que a margem de manobra política em países periféricos constrangidos (no nosso caso, de muito bom grado) a embarcar no processo de globalização em curso pela via de mão única dos programas de estabilização em marcha forçada, é praticamente nula. Como entramos na era da globalização exclusivamente pela janela financeira, vivemos num mundo de curto prazo cujo comando econômico obedece a uma estratégia global. Assim, cada gesto do Poder Executivo (para não falar no ritual obsoleto que ainda insistimos em chamar eleição) é imediatamente sancionado em primeira e última instância pelos "mercados": quem sair da linha é imediatamente punido por retaliações fulminantes contra a sua moeda. Nestas condições compete ao Poder Executivo vender credibilidade aos analistas financeiros dos países centrais. Ora, entre as principais garantias está a promessa de que "política" é coisa do passado, salvo a atração turística periódica mencionada há pouco, mas disso a mídia e a ficção da moeda forte se encarregam. De fato, ficou muito fácil governar, pois não há mesmo nada a fazer. Daí o faz-de-conta em que vivemos. No mundo repetitivo da estabilização pela estabilização, mesmo que protocolarmente ainda se mantenha o cacoete de falar em crescimento, estabilização cujo lastro é uma nuvem de um trilhão de dólares, pode-se até dizer que o Poder Executivo que não for ostensivamente decorativo como uma tela abstrata elegantemente ornamental deixa de ser funcional para a crença externa na nossa consistência macroeconômica, a salvo de ataques irracionais dos "políticos". Exagero? Má vontade estilizada? Acontece, que nós somos o último milagre latino-americano dos anos 90 a entrar em cena, e como tal "produzido" por uma conjunção aleatória de globalização financeira, recessão mundial e juros baixos no Primeiro Mundo. O elemento decorativo em questão, tendo tudo a ver com essa "produção" mirabolante, simplesmente dá forma visível à sensação difusa de irrealidade, confirmada pela ameaça cotidiana do milagre reverter em poucas horas. Escusado lembrar que noutros tempos essa irrealidade da realidade, ou realidade do irreal, atendia pelo nome de fetichismo da mercadoria. $\mathrm{O}$ Presidente é decorativo não porque lhe faltem as virtudes intrínsecas de um estadista, mas porque é o resultado milagroso do fetiche da moeda estável.

Tudo isso poderia ser dito de outra maneira, e de fato o foi. No mesmo dia em que o professor Fiori impatrioticamente punha em dúvida a autoridade do nosso primei- 
ro mandatário, a imprensa local publicava um artigo do teórico alemão Robert Kurz em que rigorosamente se demonstrava a mesma coisa, porém nos termos mais gerais de uma "economia política da simulação". A ideia é mais ou menos a seguinte: pode-se demonstrar, sem extrapolar um milímetro do mais elementar cálculo capitalista, que os custos operacionais da sociedade, medidos no caso pelo consumo social do Estado, numa economia de mercado, ficaram tão altos que ela já não é mais rentável historicamente (tornando-se, portanto, descartável, em fatias, como estamos vendo). Daí o recurso, na intenção de encobrir tal situação, à simulação da moeda sem substância social na forma do capital fictício, tanto o do crédito governamental quanto o da especulação financeira. Procedimento simulador viável enquanto durou a grande exceção keynesiana dos 30 anos dourados do pós-guerra. Fechado o parêntese, o capital fictício do crédito governamental e do giro financeiro se apresentam inextricavelmente entrelaçados no seguinte faz-de-conta: as dívidas de um setor são "pagas" com as dívidas do outro, de sorte que o crescimento simulado -- porque ninguém está interessado em crescer, tal o pânico de que o emprego gere inflação e esta derrube a higidez vitoriana dos "mercados" -- alimenta a própria simulação. Compreende-se que nesse capitalismo-cassino de dimensões globais certos homens não possam mais se levar a sério (coisa que para um intelectual é até natural e conveniente) e nem mesmo saber se realmente ainda existem.

Não havia, portanto, na entrevista nenhuma intenção escarninha do desacato pelo desacato, pelo contrário, quem sabe até o início de uma discussão no plano mais elevado da Ontologia. (Lembro aliás, que o João da Ega, um personagem de Eça de Queiroz, que sabia muito bem o quanto sufocava a pasmaceira do mesmo, não o Eça, mas a de Portugal, costumava dizer que o desacato é a condição do progresso.)

Se a dimensão decorativa comportasse alguma dose de cinismo, que é a forma contemporânea da falsa consciência ilustrada, como um filósofo pop definiu o cínico moderno, seria o caso de imaginar um raciocínio do seguinte teor: de fato, não há mais política que não seja meramente decorativa e não chegará ao topo do Estado quem não investir na aspiração fetichista que atravessa todas as classes sociais sem exceção, pois ninguém consegue conviver com a ideia inimaginável de que uma economia totalmente monetária seja de fato inviável na prática; não só o Estado mas também os empreendimentos privados de toda ordem empenham seu futuro em lucros fictícios; ora, sem futuro não há política a menos que continuemos a chamar pelo velho nome de política a arte de entreter pela mídia a ilusão monetária daqueles que não têm dinheiro, mas votam de quatro em quatro anos. Quem raciocinasse deste modo teria por certo do seu lado a boa consciência da consistência sociológica.

Cinismoà parte, o marco zero da esquerda também tem que ser fincado neste pântano, se ela estiver disposta a sacudir a poeira do cretinismo institucional que a acometeu desde os primeiros tempos da Abertura e a fez embarcar na canoa furada de uma transição de ponta a ponta conservadora. Achávamos que tínhamos um passivo de pensamento político a descontar, quando se devia ao contrário retomar a crítica da política. Levou quem viu, mesmo sem enxergar nada, que a política sempre teve a idade histórica do fetiche econômico predominante: principiou pela fantasmagoria do "contrato" gerada na esfera da circulação e agoniza agora na forma-publicidade da riqueza financeirizada. 
O que fazer? Pelo menos dois caminhos me parecem rifados de saída. Refazer a trajetória do marxismo do apogeu social-democrata, dos tempos de Engels ao Estado Social do pós-guerra. Por não ter encarado praticamente a crítica do fetichismo da mercadoria, sob pretexto que seria devaneio utópico, elucubração negativa sem nada de positivo a propor, o marxismo ortodoxo correu pela pista inexistente da política, miragem tanto mais atraente até hoje quanto incessantemente reforçada pela lembrança épica das conquistas dos trinta anos dourados de capitalismo organizado, o mesmo que renunciando excepcionalmente às suas tendências destrutivas profundas permitiu no centro a montagem do Welfarestate, e na periferia, a nossa industrialização tardia. Tampouco me parece disponível a abstração oposta, a antipolítica dos velhos Novos Movimentos Sociais, alternativos ou não. Como já disse de outro modo a propósito do sucesso de mídia da filosofia, ocorre que os interesses não-materiais configurados ao longo das rebeliões antiprodutivistas dos anos 60 e seguintes já foram devidamente colonizados na forma do consumo cultural de estilos de vida, consumo exponenciado pelo frenesi do capitalismo-cassino, em cujo âmbito a ficção do capital-dinheiro rentista cristaliza no fetiche das "identidades", nas quais se investe como uma aplicação num derivativo como outro qualquer. Se não nos decidirmos a desatar este nó -- converter em prática social tangível a crítica da irrealidade fetichista do capitalismo mundializado e finalmente entregue a si mesmo, e largar de vez a intenção piedosa de reorganizá-lo mais uma vez -- envelheceremos mais uma geração no campo das artes políticas decorativas. Como lembrado há pouco, dividido em dois blocos, o dos ajustados e o dos desajustados. Estou de acordo em situar à direita os primeiros, e à esquerda os segundos, inclusive por um senso elementar de continuidade histórica e solidariedade social. Mas convenhamos: aliviados pelo justo destampatório, continuamos na mesma, sob o fogo cruzado das críticas de sinal trocado, porém simétricas: o que para uns é inserção dinâmica, para outros é estática, o que para uns é sistêmico, para outros é espúrio, e assim sucessivamente como no mau infinito da velha matemática. Uma coisa pelo menos é certa: acho que já dá para perceber que não se romperá o bonapartismo global dos "mercados" elegendo-se presidentes de esquerda (é bem verdade que a esse novíssimo bonapartismo devemos o tira-gosto, reconheço que um tantinho perverso, de ver apertar-se cada vez mais o estado de sítio moral em que vivem nossas elites separatistas).

Sirva de lição o nosso drama. O Partido Intelectual a que pertenço, mesmo na qualidade de simples casaca-de-ferro, e que não posso mais renegar, preparou-se durante trinta anos e sua fração majoritária acabou chegando lá. E o que se está vendo? Retrospectivamente pelo menos, já que seria ocioso profetizar, de tanto sermos positivamente "do contra" fomos a rigor colecionando argumentos "a favor" do capitalismo mundializado antes do seu triunfo. Os "mercados" penhorados agradecem a grata surpresa de tão fina apoteose intelectual, com a qual sinceramente jamais esperaram contar.

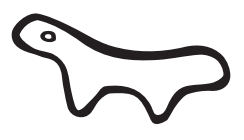

Este livro foi composto nas fontes Literata e Work Sans em julho de 2021. 